ADALTO DE FARIAS

\title{
ANÁLISE DA TENSÃO RESIDUAL E INTEGRIDADE SUPERFICIAL NO PROCESSO DE TORNEAMENTO EM MATERIAL ENDURECIDO DO AÇO ABNT 8620 CEMENTADO
}

Dissertação apresentada à Escola Politécnica da Universidade de São Paulo para obtenção do título de Mestre em Engenharia Mecânica

São Paulo 


\section{ANÁLISE DA TENSÃO RESIDUAL E INTEGRIDADE SUPERFICIAL NO PROCESSO DE TORNEAMENTO EM MATERIAL ENDURECIDO DO AÇO ABNT 8620 CEMENTADO}

Dissertação apresentada à Escola Politécnica da Universidade de São Paulo para obtenção do título de Mestre em Engenharia Mecânica

Área de concentração:

Engenharia Mecânica de Projeto e Fabricação

Orientador: Prof. Dr. Gilmar Ferreira Batalha

São Paulo

2009 
Este exemplar foi revisado e alterado em relação à versão original, sob responsabilidade única do autor e com anuência de seu orientador.

São Paulo, 06 de maio de 2009.

Assinatura do autor:

Assinatura do orientador:

\section{FICHA CATALOGRÁFICA}

Farias, Adalto de

Análise da tensão residual e integridade superficial no processo de torneamento em material endurecido do aço ABNT 8620 cementado / A. de Farias. -- São Paulo, 2009.

$191 \mathrm{p}$.

Edição Revisada de Dissertação (Mestrado) - Escola Politécnica da Universidade de São Paulo. Departamento de Engenharia Mecatrônica e de sistemas Mecânicos.

1.Usinagem 2.Torneamento 3.Difração por raios-X 4.Tensão Residual 5.Acabamento de superfícies I. Universidade de São Paulo. Escola Politécnica. Departamento de Engenharia Mecatrônica e de Sistemas Mecânicos II. t. 


\section{DEDICATÓRIA}

Dedico este trabalho à minha esposa Evelin e minhas filhas Alice e Eliza pelo apoio, paciência e compreensão nos momentos de ausência.

Ao meu pai Américo (in memorian), que estaria orgulhoso pelo meu esforço. 


\section{AGRADECIMENTOS}

Ao Prof. Dr. Gilmar Ferreira Batalha, pela brilhante orientação, pela constante dedicação e amizade durante todo o trabalho.

Ao Prof. Dr. Sérgio Delijaicov, pela co-orientação deste trabalho, pela competente ajuda nos momentos de dúvidas e sua grande amizade.

Aos meus sogros Carlos e Neide pelo apoio, estímulo e dedicação à minha família.

À minha mãe Ana e meu irmão Adriano pelo apoio e estímulo.

À empresa Polimold Ind. S/A, pela grande oportunidade de executar este trabalho, por todo o suporte dado tanto em material quanto em tempo.

Ao Sr. Ruy Korbivcher e Sr. José Carlos Felipe Fischer pelo apoio e amizade durante todos estes anos de trabalho.

Ao engenheiro Anderson Cleber N. Silva e o gerente Jacques W. Mazo da empresa Seco Tools Brasil, pelo fornecimento das ferramentas e apoio nas usinagens dos corpos de prova.

Ao Prof. Dr. Daniel Biasoli de Melo, pela ajuda e ensinamentos sobre medições de topografias superficiais.

Aos alunos Felipe e Karina do laboratório de materiais da UNIFEI pela grande ajuda nas medições das tensões residuais no método do furo cego e preparação das amostras metalográficas.

Ao Prof. Dr. Nelson Batista e Renê do IPEN pelas medições de tensão residual com raios- $\mathrm{X}$.

A todos os colegas que direta ou indiretamente contribuíram para realização deste trabalho, e, especialmente a Deus por mais esta realização. 
Se eu vi mais longe, foi por estar de pé sobre ombros de gigantes

(Isaac Newton) 


\section{RESUMO}

Este trabalho tem a intenção de contribuir com informações sobre a integridade superficial resultante do processo de torneamento em material endurecido de componentes mecânicos fabricados em aço cementado ABNT 8620 (DIN 21 NiCrMo 2). A análise das tensões residuais do corpo de prova foi experimentalmente conduzida pelo Método do Furo Cego Incremental, no qual um pequeno furo é introduzido na superfície do componente e a deformação aliviada é registrada por meio de extensômetros especiais, e também, pelo método da difração de raios-X. A superfície foi analisada através de parâmetros obtidos do mapeamento tridimensional da topografia superficial com instrumento de interferometria laser. Os parâmetros de rugosidade, selecionados para medição, visaram uma caracterização funcional das superfícies obtidas, tais como capacidade de carga, capacidade de retenção de fluidos lubrificantes e resistência ao desgaste. Também foram executados ensaios metalográficos para avaliar a existência de camadas de material alteradas abaixo da superfície. Os resultados indicaram que o torneamento em material endurecido foi capaz de produzir uma superfície resultante com boa área de contato, boa capacidade de carregamento e razoável capacidade de retenção de fluidos uma vez que nem todos os parâmetros se encontraram na faixa funcional ideal. O torneamento em material endurecido induziu tensão de compressão nas camadas das amostras cementadas, cuja condição original era tensão residual de tração. Não foram detectadas alterações expressivas na camada cementada, principalmente na região limítrofe da área transversal com a superfície devido ao aquecimento e rápido resfriamento imposto pelo processo de usinagem.

Palavras-chave: Usinagem, integridade superficial, aço cementado, rugosidade 3-D, camada branca, tensão residual, difração de raios- $X$, método do furo cego. 


\begin{abstract}
The aim of the present work is to provide relevant information regarding the obtained surface integrity during hard turning process of mechanical components manufactured from case hardened steel ABNT 8620 (DIN 21 NiCrMo 2). The sample residual stress analysis has been experimentally conducted by the incremental Blind Hole method, in which a small hole is machined on the surface of the component and the relieved deformation is recorded through special strain gages, and by the X-ray diffraction technique. The surface was examined by parameters obtained from the surface topography three-dimensional mapping with a laser interferometer instrument. The selected roughness parameters analysis intends to have a functional characterization such as bearing capacity, fluid and lubricants retention ability and contact wear resistance. In the search for altered material layers beneath the surface, metallographic studies were carried out. The functional bearing area curve analysis parameters indicated that the resulting surface has a good area contact, good bearing capacity and reasonable ability to fluid retention as the reduced valley depth parameter did not produced negative values for all conditions tested. The hard turnig process was able to add compression residual stress condition at the surface, and no significant changes were found at the case hardened layer due to rapid heating and cooling imposed by the hard turning process.
\end{abstract}

Keywords: Surface integrity, hard turning, case hardened steel, 3-D roughness, white layers, residual stress, X-ray diffraction, blind hole method. 


\section{LISTA DE FIGURAS}

Figura 1. Definições de Integridade Superficial.

Figura 2. Influências na geração de uma Integridade Superficial..............................33

Figura 3. As cinco classes de processos arquétipos de usinagem...........................34

Figura 4. Relações entre desgaste de flanco (VBc) e forças de corte........................35

Figura 5. Seção esquemática de uma superfície em aço usinada. ........................ 36

Figura 6. Camada branca com espessura média de $7 \mu \mathrm{m}$ gerada por retificação em

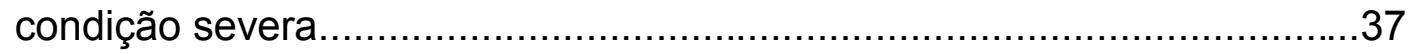

Figura 7. A influência do processo de usinagem na fadiga....................................38

Figura 8. Comparação da vida útil em teste de rolamento de contato para aço

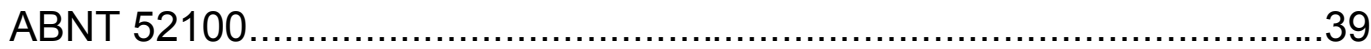

Figura 9. Perfil de durezas em camadas subsuperficiais..................................41

Figura 10. Zona de deformação plástica localizada em subsuperficie usinada......42

Figura 11. Micrografia MEV da zona de deformação plástica localizada em subsuperficie usinada.

Figura 12. Seção radial por um furo em cobre (a) e sua tensão associada (b).......43

Figura 13. Zona deformada em camada subsuperficial de um aço inoxidável (a) secção transversal, e (b) secção paralela ao eixo do furo.

Figura 14. Seç̧ão mostrando uma camada branca produzida por torneamento em condição severa. 45

Figura 15. Aumento da dureza produzido por diferentes tratamentos. 45

Figura 16. Formaçao de rebarbas sem a presença de desgaste (a) e na presença de desgaste de ferramenta (b).

Figura 17. Trinca por deformação plástica em aço temperado e revenido. .47

Figura 18. Fluxo lateral de material. 48

Figura 19. Arranque de material na camada branca superficial em processo de retificação em condição severa.

Figura 20. Grão de ferrita depositado em uma superfície de ferro fundido. 49

Figura 21. Desgaste da ferramenta com o tempo e a relação às condições de usinagem. .50

Figura 22. A influência do desgaste em ferramenta de torno sobre o fluxo de calor nas interfaces cavaco/ferramenta e peça/ferrament. 
Figura 23. A influência da zona desgastada em ferramenta de torno sobre o fluxo de calor e a profundidade de deformação plástica......................................52

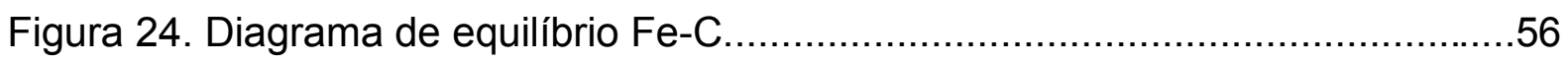

Figura 25. Concentração de carbono na superfície para o aço ABNT $8620 \ldots \ldots \ldots \ldots . . .58$

Figura 26. Efeito do tempo e temperatura na profundidade da camada

cementada. .58

Figura 27. Relação entre tempo e temperatura na cementação do aço ABNT 8620 para uma mesma camada efetiva de $1,5 \mathrm{~mm}$.

Figura 28. Distribuição esquematizada da profundidade da concentração de carbono e da dureza em uma peça cementada.

Figura 29. Perfil de tensão residual de superfície após processo de cementação..60

Figura 30. Relação entre ponto de orvalho e potencial de carbono para (a) gás

metano e (b) gás propano.

Figura 31. Relação entre $\mathrm{CO}_{2}$ e potencial de carbono para (a) gás metano e (b) gás propano

Figura 32. Diagrama de resfriamento contínuo para o aço ABNT 8630 cementado. 66

Figura 33. Diagrama de revenimento para aço com $0,82 \%$ de $\mathrm{C}$ e $0,75 \% \mathrm{Mn}$. 68

Figura 34. A correlação entre porcentagem de carbono e porcentagem de austenita para componentes cementados. .70

Figura 35. Distribuição esquematizada da profundidade da concentração de carbono e da dureza em uma peça cementada. 71

Figura 36. Geometria do corte ortogonal............................................... 74

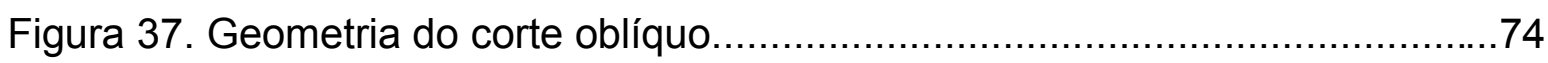

Figura 38. Zonas de deformação por cisalhamento....................................75

Figura 39. Arranque de cavaco na usinagem de torneamento oblíquo..................76

Figura 40. Diagrama de forças no corte ortogonal............................................77

Figura 41. Formato deixado pela usinagem em torneamento.............................80

Figura 42. Imagem óptica da superfície usinada em torneamento........................80

Figura 43. Ponta com geometria convencional(a) e multi-raio wiper (b)...............81

Figura 44. Acúmulo de material com ferramenta de ângulo de saída de $-70^{\circ} \ldots \ldots . .82$

Figura 45. Efeito do ângulo de saída na força de corte para vários materiais.........83

Figura 46. Forças no corte ortogonal em funçao do tempo, ferramenta em cBN, $V_{c}=145 \mathrm{~m} / \mathrm{min}$ e $a_{p}=0.2 \mathrm{~mm}$ 
Figura 47. Efeito da velocidade de corte e do desgaste de flanco nas componentes da força de usinagem (a) $V_{c}=100 \mathrm{~m} / \mathrm{min}$, (b) $V_{c}=145 \mathrm{~m} / \mathrm{min}$ e (c) $\mathrm{V}_{\mathrm{c}} 220 \mathrm{~m} / \mathrm{min}$ .84

Figura 48. Formação do cavaco no torneamento de materiais endurecidos. .85

Figura 49. Formação do cavaco em perfil dente de serra. .86

Figura 50. Modelo em elementos finitos da geração de cavacos e temperaturas. (a) Comparação com micrografia experimental, (b) valores de temperaturas.

Figura 51. (a)Modelo em elementos finitos da geração de cavacos e temperaturas para profundidade de corte de $60 \mu \mathrm{m}$. (b) Micrografia experimental.

Figura 52. (a)Modelo em elementos finitos da geração de cavacos e temperaturas para profundidade de corte de $90 \mu \mathrm{m}$. (b) Micrografia experimental...........88

Figura 53. Pó de Nitreto de Boro hexagonal.............................................89

Figura 54. Grãos de cBN sinterizados. 89

Figura 55. Exemplos de insertos $c B N$ : (a) cBN ponta brasada diretamente no inserto de carboneto,(b) inserto multiplo, (c) inserto cBN com trava de fixação mecânica e cantos sólidos brasados em posição afastada do contato cavaco-ponta, (d) inserto cBN com quebra-cavaco e (e) inserto de cBN sólido com cobertura total (TiC).

Figura 56. Variação da dureza com a temperatura para diferentes materiais de ferramenta.

Figura 57. Modos de desgaste de ferramenta (a) Desgaste de flanco (VB), (b) desgaste de cratera.

Figura 58. Modos de falha da ferramenta em funçao da condição de usinagem....93

Figura 59. Topografia da superfície (a) torneada e (b) polida. .94

Figura 60. Relações entre um modelamento de superfície. .95

Figura 61. Procedimento geral para avaliação de topografia superficial 3-D. .96

Figura 62. Sistema de coordenadas para representação de topografia superficial. .96

Figura 63. Classificação de instrumentos de medição topográfica baseados em seu princípio de aquisição de dados .97

Figura 64. Interferômetro a laser.. .98

Figura 65. Perfilômetro apalpador. .98

Figura 66. Perfilômetro de câmera 
Figura 67. Análise de rugosidades com diferentes áreas de avaliação de uma mesma superfície.

Figura 68. Classificação de valores para Assimetria da Distribuição das Alturas..105

Figura 69. Classificação de valores para Curtose da Distribuição das Alturas......106

Figura 70. Distribuição de picos e vales e Parâmetros Funcionais Baseados na curva de Abbott-Firestone ou Curva da Área de Carregamento 106

Figura 71. Tensão residual em vários processos para o aço AISI 4340 temperado e revenido com $510 \mathrm{HV}(50 \mathrm{HRC})$.

Figura 72. Distribuição da tensão residual em sub-camadas obtida por torneamento duro com CBN seguido de retificação com cinta de lixa......112

Figura 73. Tensão residual e resistência à fadiga.....................................112

Figura 74. Preparação de aresta (a) chanfro simples e (b) chanfro......................114

Figura 75. Preparação de aresta com chanfro e raio.......................................114

Figura 76. Extensômetro Roseta (strain gage) para medição do processo de furo cego.

Figura 77. Detalhes do dispositivo para furação 117

Figura 78. Relação entre dimensões do extensômetro e as dimensões do furo....118

Figura 79. Difração de raios-X em cristais simples carregados e descarregados.. 120

Figura 80. Estado plano de tensões....................................................122

Figura 81. Elipsóide das deformações............................................................122

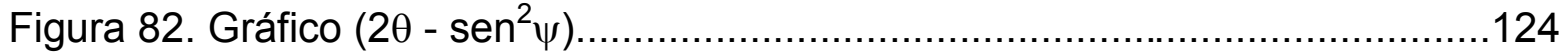

Figura 83. Representação simplificada do corpo de prova utilizado no experimento de torneamento endurecido........................................................... 125

Figura 84. Ferramenta montada na torre de ferramentas do torno......................126

Figura 85. Centro CNC de torneamento marca INDEX MC400.......................127

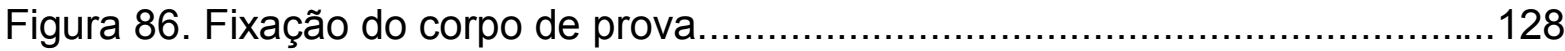

Figura 87. Usinagem de um corpo de prova sem fluido de refrigeração ou corte..128 Figura 88. Dispositivo para usinagem do furo para alívio de deformações.............129

Figura 89. Sequência para brasagem dos fios do extensômetro.........................131

Figura 90. Corpo de prova instrumentado com roseta e respectivos terminais para instrumentação.............................................................................

Figura 91. Brasagem dos cabos no terminal..............................................131

Figura 92. Fixação do corpo de prova e dispositivo com resina plástica................132

Figura 93. Indicador e gravador de microdeformações modelo P3-Vishay.............133 
Figura 94. Detalhe da fresa executando o furo

Figura 95. Montagem utilizada para usinagem do furo e coleta dos valores de deformação. 135

Figura 96. Indicação dos sentidos de leitura da tensões 136

Figura 97. Difratômetro de Raios-X, marca RIGAKU - DMAX Rint 2000. 137

Figura 98. Equipamento de Interferometria laser utilizado para a medição de

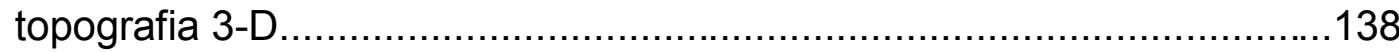

Figura 99. Interferômetro laser utilizado para a medição de topografia 3-D..........138

Figura 100. Medição de um corpo de prova com interferômetro laser. 139

Figura 101. Software de aquisição de dados acoplado ao Interferômetro laser utilizado para a medição de topografia 3-D.

Figura 102. Fluxo do tratamento efetuado em cada topografia 3-D antes de tomada de valores 140

Figura 103. Tela do software Mountains Map versão 3.1.9 (versão Demo)- empresa Digital Surf 140

Figura 104. Amostras embutidas em baquelite, a) Somente polida, b) Com ataque nital de $3 \%$ 141

Figura 105. Microscópio eletrônico de varredura LEO 440................................142

Figura 106. Amostras embutidas em baquelite preparadas para o MEV..............142

Figura 107. Microdurômetro HMV - Shimadzu HVM-2 344 ..............................143

Figura 108. Medição de dureza efetuada nas amostras....................................143

Figura 109. Perfil de Tensão Residual Axial..................................................144

Figura 110. Perfil de Tensão Residual Circunferencial......................................145

Figura 111. Perfil de Tensão Residual Axial da amostra cementada....................146

Figura 112. Perfil de Tensão Residual Circunferencial da amostra cementada....146

Figura 113. Perfil de Tensão Residual Axial da amostra retificada......................147

Figura 114. Perfil de Tensão Residual Circunferencial da amostra retificada.......147

Figura 115. Tensão Residual Circunferencial na superfície das amostras............148

Figura 116. Topografia da superfície usinada com Velocidade de Corte $180 \mathrm{~m} / \mathrm{min}$ e Avanço $0,05 \mathrm{~mm} / \mathrm{rot}$ 149

Figura 117. Topografia da superfície usinada com Velocidade de Corte $180 \mathrm{~m} / \mathrm{min}$ e Avanço $0,08 \mathrm{~mm} /$ rot 149

Figura 118. Topografia da superfície usinada com Velocidade de Corte $180 \mathrm{~m} / \mathrm{min}$ e Avanço $0,12 \mathrm{~mm} / \mathrm{rot}$ 150 
Figura 119. Topografia da superfície usinada com Velocidade de Corte $200 \mathrm{~m} / \mathrm{min}$ e Avanço $0,05 \mathrm{~mm} / \mathrm{rot}$ 150

Figura 120. Topografia da superfície usinada com Velocidade de Corte $200 \mathrm{~m} / \mathrm{min}$ e Avanço $0,08 \mathrm{~mm} / \mathrm{rot}$ 150

Figura 121. Topografia da superfície usinada com Velocidade de Corte $200 \mathrm{~m} / \mathrm{min}$ e

Avanço $0,12 \mathrm{~mm} / \mathrm{rot}$ 151

Figura 122. Topografia da superfície Retificada em condições convencionais.......151

Figura 123. Desvio Médio Aritmético da Superfície $-S_{a}$ 152

Figura 124. Desvio Médio Quadrático da Superfície - $S_{q}$. 152

Figura 125. Assimetria da Distribuição das Alturas $S_{\text {sk. }}$ 153

Figura 126. Curtose da Distribuição das Alturas $S_{k u}$ 153

Figura 127. Altura Reduzida do Pico $S_{p k}$ 154

Figura 128. Profundidade da Rugosidade do Núcleo $S_{k}$ 154

Figura 129. Profundidade reduzida do Vale $S_{\mathrm{vk}}$ .155

Figura 130. Porção do Material da Superfície $M_{r 1}$ .155

Figura 131. Porção do Material da Superfície $M_{r 2}$ 156

Figura 132. Amostra com $V_{c}=180 \mathrm{~m} / \mathrm{min}$ e $\mathrm{f}=0.05 \mathrm{~mm} / \mathrm{rot}$ 156

Figura 133. Amostra com $V_{c}=180 \mathrm{~m} / \mathrm{min}$ e $\mathrm{f}=0.08 \mathrm{~mm} / \mathrm{rot}$ 157

Figura 134. Amostra com $V_{c}=180 \mathrm{~m} / \mathrm{min}$ e $\mathrm{f}=0.12 \mathrm{~mm} / \mathrm{rot}$ 157

Figura 135. Amostra com $V_{c}=200 \mathrm{~m} / \mathrm{min}$ e $\mathrm{f}=0.05 \mathrm{~mm} / \mathrm{rot}$ .157

Figura 136. Amostra com $\mathrm{V}_{\mathrm{c}}=200 \mathrm{~m} / \mathrm{min}$ e $\mathrm{f}=0.08 \mathrm{~mm} / \mathrm{rot}$ 157

Figura 137. Amostra com $V_{c}=200 \mathrm{~m} / \mathrm{min}$ e $\mathrm{f}=0.12 \mathrm{~mm} / \mathrm{rot}$ .157

Figura 138. Amostra MEV com $V_{c}=200 \mathrm{~m} / \mathrm{min}$ e $\mathrm{f}=0.05 \mathrm{~mm} / \mathrm{rot}$ .158

Figura 139. Amostra MEV com $V_{c}=200 \mathrm{~m} / \mathrm{min}$ e $\mathrm{f}=0.12 \mathrm{~mm} / \mathrm{rot}$ 158

Figura 140. Endentações para medição em Vickers (a) Inicio da camada, (b) meio da camada e (c) fim da camada. 159

Figura 141. Curva de dureza da camada cementada após o torneamento endurecido, carga de $0,49 \mathrm{~N}(0,05 \mathrm{~kg})$.

Figura 142. Gráfico tridimensional da Tensão Residual em função Velocidade de Corte e Avanço. 161

Figura 143. Rugosidade média aritmética em função da Velocidade de Corte e Avanço. 165

Figura 144. Rugosidade média quadrática em função da Velocidade de Corte e Avanço. 
Figura 145. Curtose da Distribuição da rugosidade em função da Velocidade de Corte e Avanço.

Figura 146. Assimetria da Distribuição da rugosidade em função da Velocidade de

Corte e Avanço. 166

Figura 147. Altura reduzida dos picos em função da Velocidade de Corte e

Avanço.

Figura 148. Rugosidade do núcleo em função da Velocidade de Corte e Avanço.

Figura 149. Profundidade reduzida dos vales em função da Velocidade de Corte e Avanço 168

Figura 150. Comparação dos valores de $S_{a}$ para Torneamento duro e Retificação Convencional. 169

Figura 151. Comparação dos valores de $S_{\mathrm{ku}}$ para Torneamento duro e Retificação Convencional 169

Figura 152. Comparação dos valores de $S_{\text {sk }}$ para Torneamento duro e Retificação Convencional

Figura 153. Gráficos de análise de resíduos 187

Figura 154. Gráficos de análise das medições de tensão encontradas na Superfície. 188 


\section{LISTA DE TABELAS}

Tabela 1. Condições de usinagem para o aço ABNT 52100

Tabela 2. Relação entre classes de processos, características subsuperficiais e condições de operação.

Tabela 3. Influência das características subsuperficiais nas situações funcionais...53

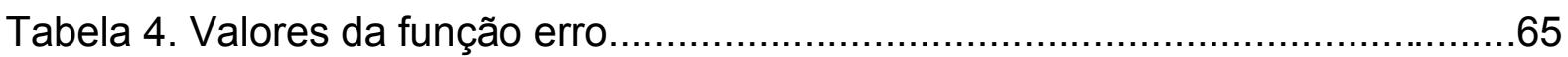

Tabela 5. Efeito da austenita retida segundo vários pesquisadores.......................70

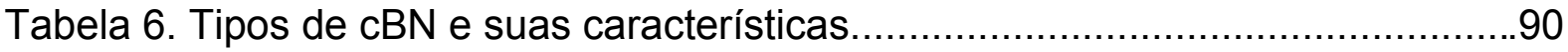

Tabela 7. Significado funcional dos parâmetros de rugosidade.............................104

Tabela 8. Referência funcional dos parâmetros de rugosidade.............................107

Tabela 9. Tensão residual produzidas por processos de usinagem típicos............112

Tabela 10. Composição química em \%peso conforme Norma SAE - J404 ............126

Tabela 11. Normas de equivalências do aço ABNT 8620.....................................126

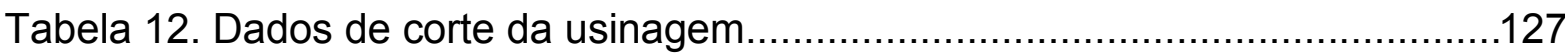

Tabela 13. Resultados ANOVA para Tensão Residual superficial..........................161

Tabela 14. Resultados ANOVA para topografia superficial....................................162

Tabela 15. Resultados obtidos para torneamento duro e retificação........................163

Tabela 16. Resultados obtidos para torneamento duro e torneamento duro seguido

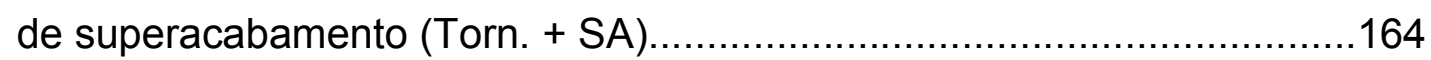

Tabela 17. Parâmetros de corte tabelados e associados.......................................183

Tabela 18. Resultados de medição de tensão residual com o método de furo cego

Tabela 19. Resultados de Tensão Residual Superficial no sentido

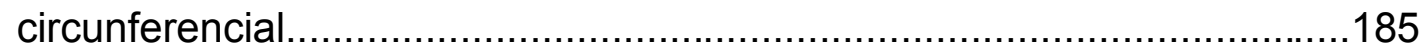

Tabela 20. Resultados da medição topográfica 3-D..........................................189 


\section{LISTA DE ABREVIATURAS E SIGLAS}

ABNT Associação Brasileira de Normas Técnicas

AFNOR Association Française de Normalisation

AISI American Iron and Steel Institute

ASM American Society of Materials

ASTM American Society for Testing Materials

BS British Standard

CCC Cúbico de corpo centrado

CMA Camadas de Material Alteradas

CMQA Camada de material quimicamente alterada

CMMA Camada de material mecanicamente alterada

CMTA Camada de material termicamente

CMAT Camada de material alterada por tensões

CB Camada Branca

cBN Nitreto de Boro cúbico

DIN Deutsches Institut fuer Normung

ISO International Standart Organization

IS Integridade Superficial

IT6 Qualidade grupo 6 na tabela ISO

JIS Japanese Industrial Standards

MNR Martensita não revenida

MSR Martensita sobre revenida

MEV Microscópio eletrônico de varredura

SAE Society of Automotive Engineers

TCC Tetragonal de corpo centrado

$\mathrm{W} \mathrm{Nr} \quad$ Werkstoffnummer

3-D Três dimensões

2-D Duas dimensões 


\section{LISTA DE SÍMBOLOS}

Símbolo

Descrição

Unidade

$a_{p} \quad$ Profundidade de Corte

$\mathrm{mm}$

$A_{s} \quad$ Área do plano de cisalhamento

$\mathrm{mm}^{2}$

b Largura de corte de cavaco

$\mathrm{mm}$

$\mathrm{C}_{0} \quad$ Teor de carbono no núcleo do material

$\%$

Cs Concentração de carbono junto a superfície

$\%$

$C_{x} \quad$ Concentração de carbono na posição " $x$ "

$\%$

d Parâmetro do reticulado

D Coeficiente de difusão

$\mathrm{m}^{2} / \mathrm{s}$

$\mathrm{D}_{0} \quad$ Constante de difusividade

$\mathrm{m}^{2} / \mathrm{s}$

erf(z) Função erro para a variável $(z)$

Eht $\quad$ Profundidade da camada cementada (Einsatzthärtungstief) $\quad \mu \mathrm{m}$

E Módulo de elasticidade

$\mathrm{GPa}$

f Avanço

$\mathrm{mm} / \mathrm{rot}$

F Força resultante

$\mathrm{N}$

$\mathrm{F}_{\mathrm{p}} \quad$ Força de passiva

$\mathrm{N}$

$\mathrm{F}_{\mathrm{c}} \quad$ Força de corte

$\mathrm{N}$

$\mathrm{F}_{\mathrm{t}} \quad$ Força tangencial $\mathrm{N}$

$\mathrm{F}_{\mathrm{f}} \quad$ Força de avanço N N

$\mathrm{F}_{\mathrm{r}} \quad$ Força radial N N

$\mathrm{F}_{\mathrm{S}} \quad$ Força de cisalhamento N N

$\mathrm{F}_{\mathrm{n}} \quad$ Força normal no plano de cisalhamento terciário N

$\mathrm{F}_{\mathrm{v}} \quad$ Força normal no plano de cisalhamento secundário $\quad \mathrm{N}$

$\mathrm{F}_{\mathrm{u}} \quad$ Força de atrito

$\mathrm{N}$

$\mathrm{Fe}-\gamma \quad$ Austenita

Fe- $\delta \quad$ Ferrita

HV Dureza Vickers

HV1 Dureza Vickers com carga de $9.8 \mathrm{~N}$ 


\begin{tabular}{|c|c|c|}
\hline $\mathrm{HRC}$ & Dureza Rockwell C & \\
\hline h & Espessura de cavaco & $\mathrm{mm}$ \\
\hline i & Ângulo de inclinação no corte oblíquo & $\circ$ \\
\hline$M_{r 1}$ & Porção do Material da Superfície & $\%$ \\
\hline $\mathrm{M}_{\mathrm{r} 2}$ & Porção do Material da Superfície & $\%$ \\
\hline Nx & Número de pontos na direção $X$ & \\
\hline Ny & Número de linhas direção $Y$ & \\
\hline$P^{\prime} \alpha$ & Potência por unidade de comprimento & $\mathrm{W} / \mathrm{mm}$ \\
\hline$P " \alpha$ & Potência por unidade de área & $\mathrm{kW} / \mathrm{mm}^{2}$ \\
\hline Q & Energia de ativação para difusão & $\mathrm{J} / \mathrm{mol}$ \\
\hline $\mathrm{R}$ & Constante dos gases perfeitos & $\mathrm{J} /(\mathrm{mol} . \mathrm{K})$ \\
\hline rot & Rotação & RPM \\
\hline $\mathrm{r}_{\varepsilon}$ & Raio de ponta & $\mathrm{mm}$ \\
\hline$r_{\varepsilon 1}, r_{\varepsilon 2}$ & Raio de curvatura Wiper & $\mathrm{mm}$ \\
\hline$r_{\text {bo }}$ & Raio de alisamento & $\mathrm{mm}$ \\
\hline $\mathrm{R}_{\mathrm{z}}$ & Altura do vale até o pico & $\mu \mathrm{m}$ \\
\hline$S_{a}$ & Desvio Médio Aritmético da Superfície & $\mu \mathrm{m}$ \\
\hline$S_{q}$ & Desvio Médio Quadrático da Superfície & $\mu \mathrm{m}$ \\
\hline$S_{\text {sk }}$ & Assimetria da Distribuição das Alturas da Topografia & \\
\hline$S_{\mathrm{ku}}$ & Curtose da Distribuição das Alturas da Topografia & \\
\hline$S_{\mathrm{pk}}$ & Altura Reduzida do Pico & $\mu \mathrm{m}$ \\
\hline$S_{k}$ & Profundidade da Rugosidade do Núcleo & $\mu \mathrm{m}$ \\
\hline$S_{\mathrm{vk}}$ & Profundidade reduzida do Vale & $\mu \mathrm{m}$ \\
\hline $\mathrm{T}_{\mathrm{a}}$ & Temperatura absoluta & $\mathrm{K}$ \\
\hline $\mathrm{T}_{\mathrm{c}}$ & Temperatura na escala Celsius & ${ }^{\circ} \mathrm{C}$ \\
\hline $\mathrm{t}$ & Tempo de processo & s \\
\hline VB & Desgaste de Flanco & $\mathrm{mm}$ \\
\hline $\mathrm{V}_{\mathrm{c}}$ & Velocidade de Corte & $\mathrm{m} / \mathrm{min}$ \\
\hline$x$ & Distância no eixo das abscissas & $\mathrm{mm}$ \\
\hline$X, Y$ & Direções ortogonais em um plano xy & \\
\hline
\end{tabular}




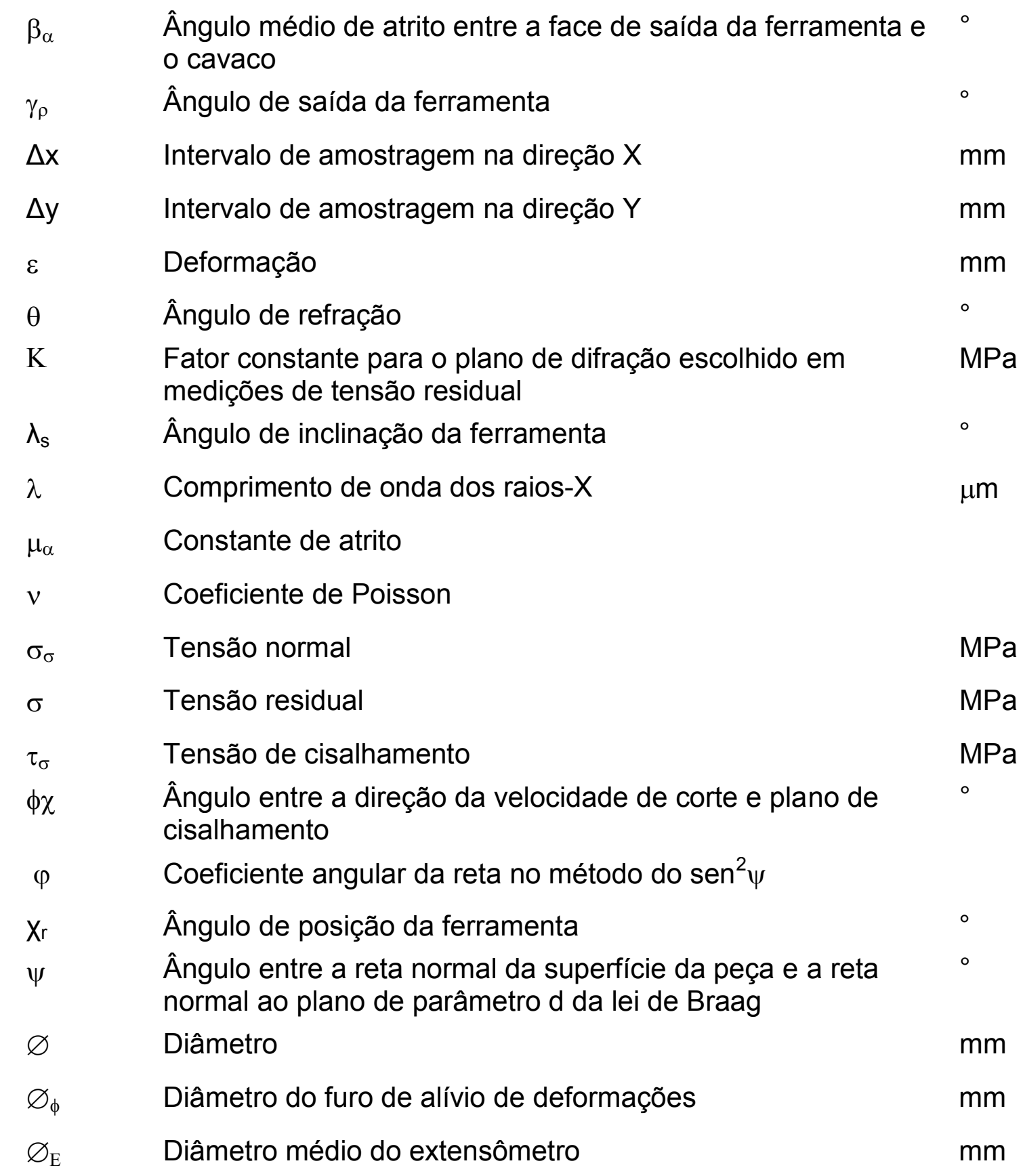




\section{SUMÁRIO}

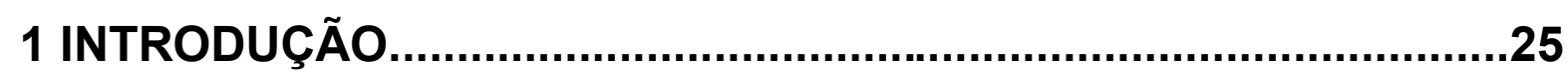

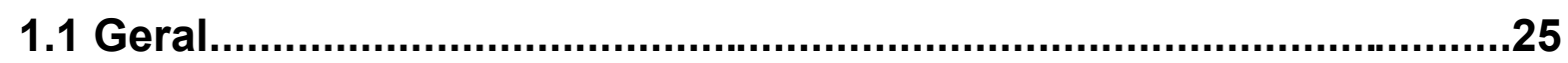

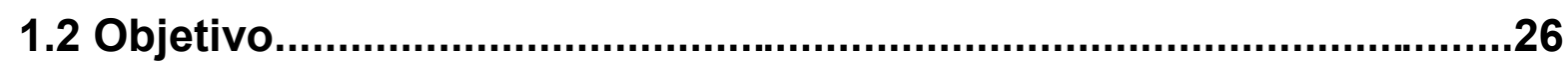

1.3 Organização da Dissertação...........................................................27

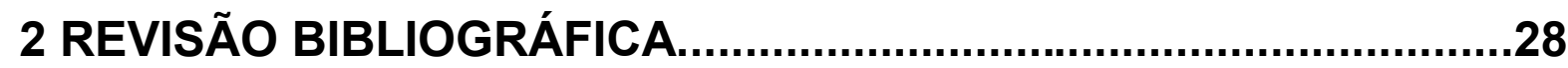

2.1 Integridade Superficial.....................................................................28

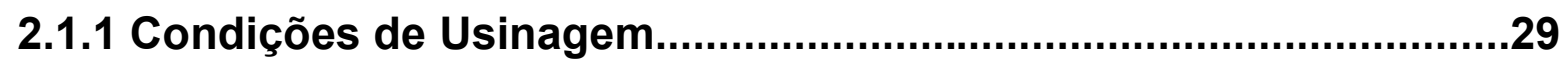

2.1.2 O Evento Unitário do Processo de Usinagem.................................31

2.1.3 Camadas de Material Alteradas - CMA............................................34

2.1.4 Martensita não Revenida - MNR e Camada Branca - CB...............35

2.1.5 Martensita SobreRevenida - MSR.................................................37

2.1.6 Deformação Plástica....................................................................39

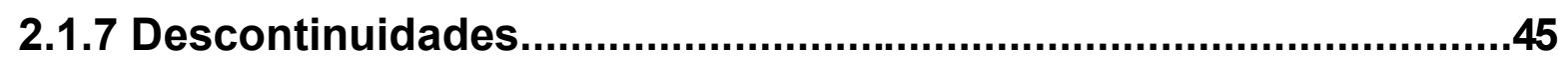

2.1.8 Camadas de Material Alterado e Evento Unitário de Usinagem.....47

2.1.9 Camadas de Material Alterado e a Temperatura.............................49

2.1.10 Camadas de Material Alterado e os Processos de Manufatura....50

2.1.11 A influência da Camada de material Alterado no Desempenho

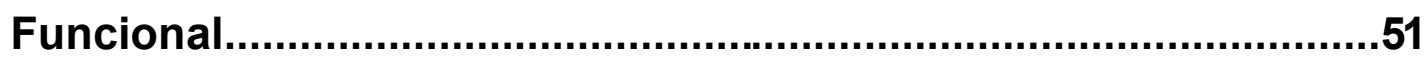

2.2 Tratamento Termoquímico de Cementação........................................52

2.2.1 Processos de Cementação............................................................52

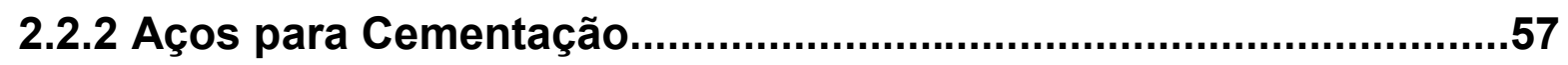

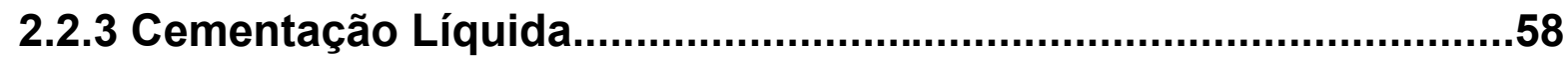

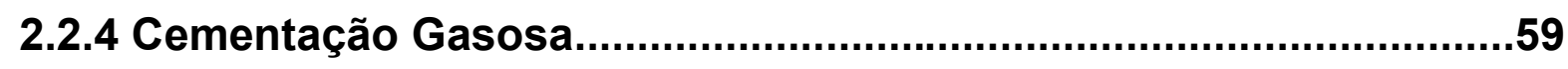

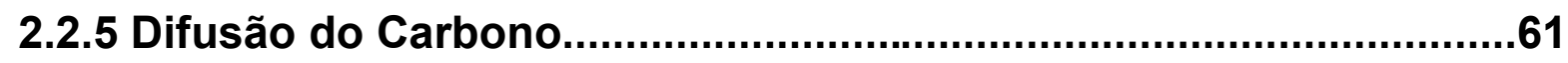

2.2.6 Tratamento Térmico após a Cementação.......................................64

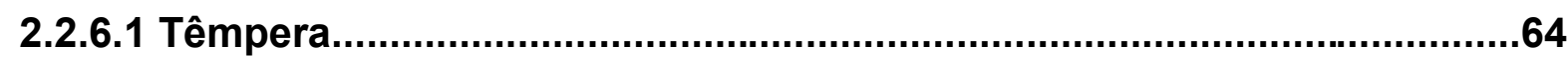

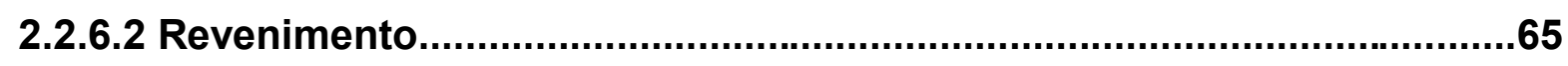

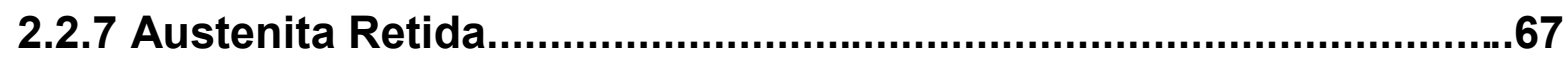


2.2.8 Medição da Camada Cementada Endurecida..................................69

2.3 Torneamento de Materiais Endurecidos..............................................71

2.3.1 Mecânica do Corte na Usinagem Ortogonal.....................................71

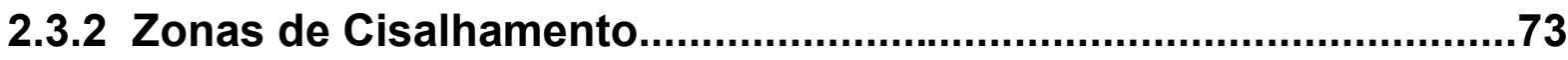

2.3.2.1 Zona de Cisalhamento Primária........................................................75

2.3.2.2 Zona de Cisalhamento Secundária.........................................................77

2.3.3 Geometria da Ponta da Ferramenta.................................................

2.3.4 Fatores de Influência nas Forças de Usinagem.............................79

2.3.5 Formação do Cavaco na Usinagem de Material Endurecido..........83

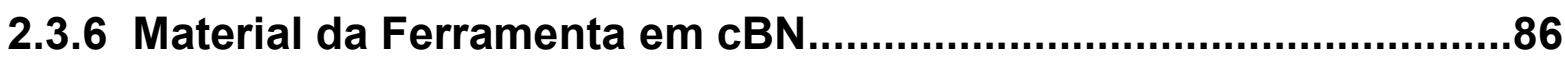

2.3.7 Propriedades da Ferramenta em cBN.........................................88

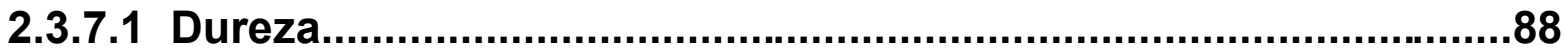

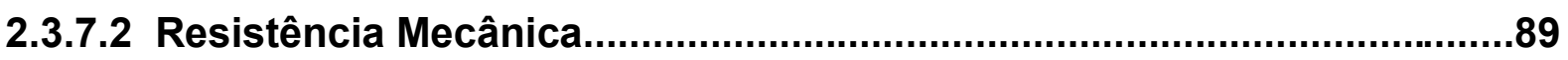

2.3.7.3 Resistência a Reações Químicas.........................................................90

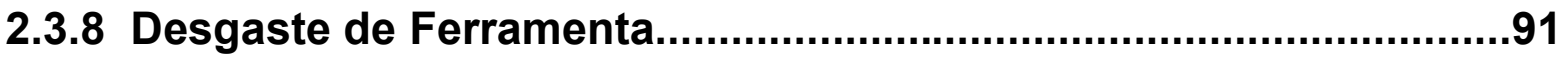

2.4 Rugosidade Superficial em Três Dimensões........................................93

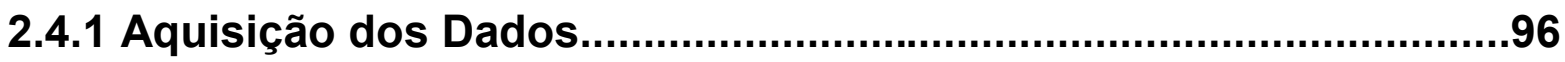

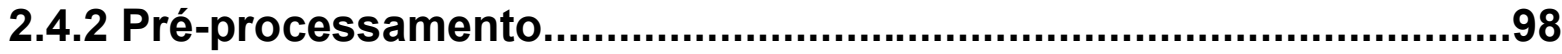

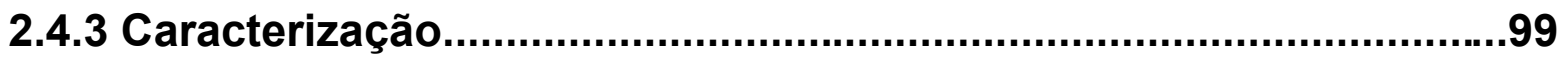

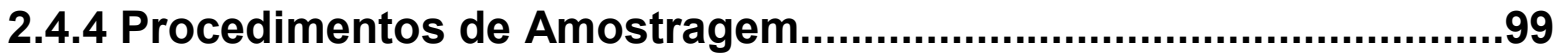

2.4.5 Área de Amostragem e Área de Avaliação......................................100

2.4.6 Parâmetros de Caracterização da Topografia Superficial 3-D.......102

2.4.6.1 Parâmetros de Amplitude....................................................................102

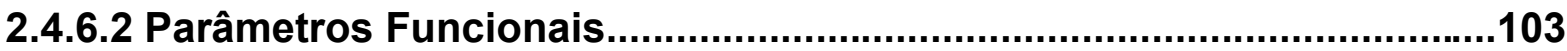

2.4.6.3 Parâmetros Funcionais da Distribuição das Alturas Baseados na Curva da Área de Carregamento........................................................104

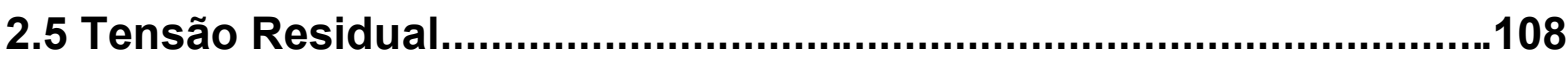

2.5.1 Mecanismos de Geração de Tensão Residual.................................109

2.5.2 Influência dos Parâmetros de Torneamento na Tensão Residual.112

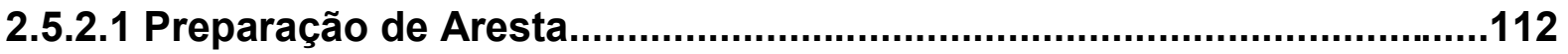

2.5.2.2 Velocidade de Corte, Avanço e Profundidade de Corte........................114 
2.5.3 Medição da Tensão Residual.....................................................114

2.5.3.1 Método do Furo Cego Incremental..................................................115

2.5.3.2 Método da Difração de Raios-X.........................................................118

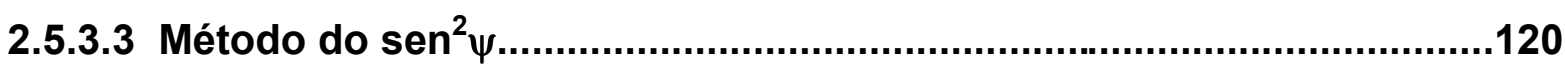

3 PROCEDIMENTO EXPERIMENTAL...........................................124

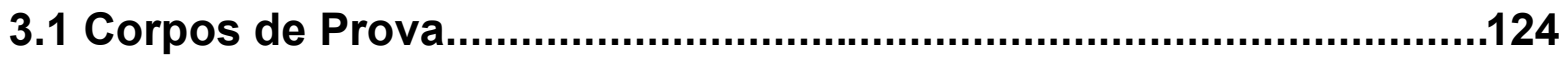

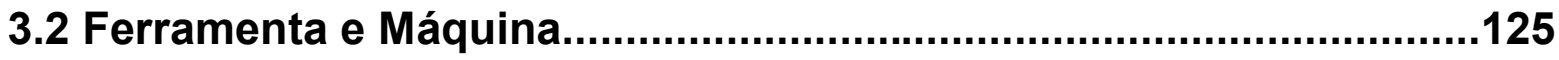

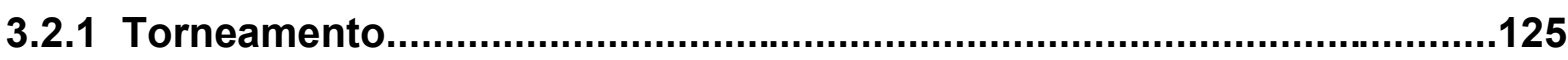

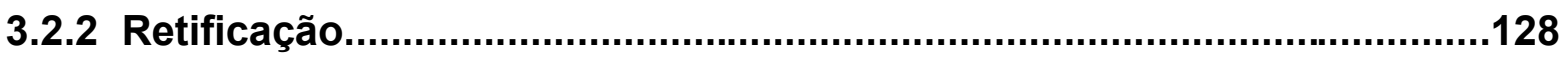

3.3 Medição da Tensão Residual pelo Método do Furo Cego.................128

3.3.1 Procedimento para Instrumentação dos Corpos de Prova para o

Método do Furo Cego.....................................................................129

3.3.2 Montagem do Ensaio do Método do Furo Cego.............................131

3.3.3 Realização do Ensaio do Método do Furo Cego............................132

3.4 Tensão Residual Superficial por Difração de Raios-X......................135

3.5 Aquisição de Dados da Topografia Superficial 3-D.........................136

3.5.1 Procedimento do Mapeamento da Superfície 3-D.........................137

3.6 Preparação Metalográfica...................................................................140

3.7 Análise no Microscópio de Varredura Eletrônica MEV....................140

3.8 Análise de Dureza por Microendentação...........................................141

4 RESULTADOS DO EXPERIMENTO..........................................143

4.1 Caracterização do Perfil de Tensão Residual...................................143

4.2 Caracterização da Tensão Residual Superficial...............................147

4.3 Caracterização da Topografia Superficial 3-D...................................148

4.4 Análise dos Parâmetros de Amplitude de Rugosidade.....................151

4.5 Análise dos Parâmetros Funcionais de Forma................................152

4.6 Análise dos Parâmetros Funcionais da Distribuição das Alturas

Baseados na Curva da Área de Carregamento................................153

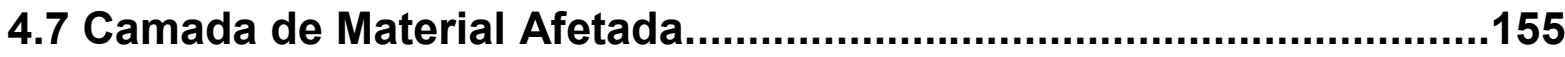

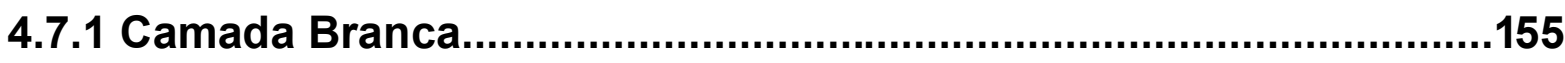


4.7.2 Perfil de Dureza da Camada Cementada após Usinagem.

5 DISCUSSÕES DOS RESULTADOS.............................................159

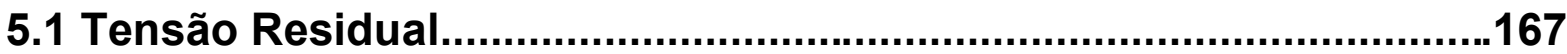

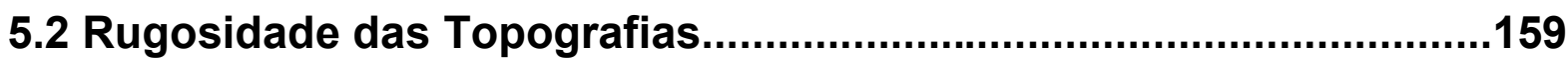

5.3 Comparação com a Condição Retificada.........................................165

5.4 Camada de Material Afetada............................................................169

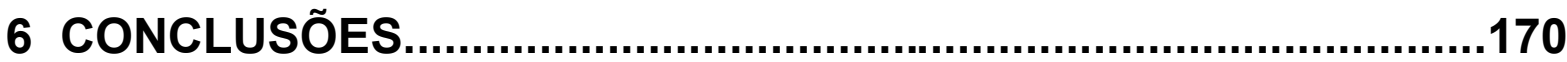

7 SUGESTÕES PARA TRABALHOS FUTUROS............................173

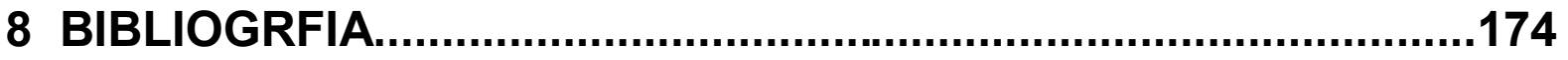

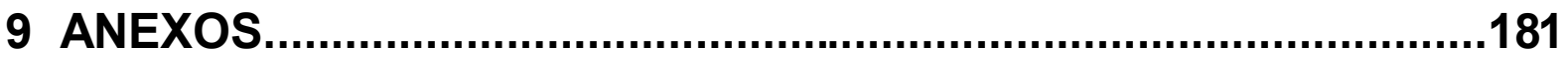

9.1 ANEXO - A: Condições do experimento de usinagem.....................181

9.2 ANEXO - B: Tensão Residual pelo método do furo cego................182

9.3 ANEXO - C: Tensão Residual por Difração de Raios-X na superfície.

9.4 ANEXO - D: Análise da variância dos Resultados de Tensão residual com o software Minitab 15...............................................................184

9.5 ANEXO - E: Resultados da medição topográfica 3-D.....................187 


\section{INTRODUÇÃO}

Com a crescente demanda por inovações nos processos produtivos e o nível atual de desenvolvimento das ferramentas de usinagem com novos materiais, geometrias e coberturas, a usinagem de aço endurecido está assumindo um grande destaque no meio acadêmico e industrial. Nas operações de acabamento em produção seriada, o torneamento de peças em aço endurecido está se tornando uma alternativa ao processo de retificação, reduzindo consideravelmente os tempos e os custos de fabricação, possibilitando em alguns casos, uma redução de até $60 \%$ (Momper, 2000). Além disso, o processo de torneamento em materiais endurecidos induz tensões residuais de compressão em camadas superficiais e sub-superficiais da peça, aumentando com isto, a sua resistência à fadiga (Matsumoto et al, 1999).

Componentes de aço altamente solicitados, como por exemplo, engrenagens, rolamentos, componentes de moldes e bases de estampo, são aplicações apropriadas para o torneamento em material endurecido. A usinagem destes componentes tem sido o domínio da retificação, porém recentemente, ferramentas em cBN (Nitreto de Boro cúbico) provaram ser uma alternativa viável. Ferramentas em cBN mostram bom desempenho durante a usinagem de materiais endurecidos por causa de sua alta dureza, baixa solubilidade em ferro, e boa tenacidade à fratura (Rech e Moisan, 2003). Alta flexibilidade e habilidade para manufaturar geometrias de peças complexas, em uma preparação, representam a principal vantagem da usinagem endurecida em comparação à retificação.

O presente projeto é uma ampliação de um trabalho de doutoramento (Delijaicov, 2004) que abordou a "Modelagem das tensões residuais no processo de torneamento duro de um aço $100 \mathrm{CrMn} 6$ e suas correlações com os esforços de corte". Nos ensaios de usinagem se usaram ferramentas de corte novas de Nitreto de Boro cúbico (cBN), anéis de aço DIN 100CrMn6, em processo de torneamento em material endurecido. Seus resultados apresentados mostraram que: os parâmetros avanço de corte (f) e a profundidade de penetração $\left(a_{p}\right)$ são os mais significativos na geração das tensões residuais $\left(\sigma_{R}\right)$ e no valor da força de passiva $\left(F_{p}\right)$. Em seu estudo Delijaicov (2004) mostou que o principal fator de influência nas tensões residuais é a força de penetração, e estabeleceu-se uma correlação entre ambas grandezas. Buscou-se confirmar neste trabalho, que uma execução 
organizada da investigação acadêmica em temas tecnológicos em parceria com o setor industrial, possibilita fornecer dados que permitam propor melhorias na qualidade e na fabricação dos seus produtos.

O uso ou não do fluido de corte, influencia fortemente o desgaste da ferramenta e a qualidade superficial das peças usinadas. O fluido age no sentido de minimizar a carga térmica na interface peça e ferramenta, auxilia na eliminação de cavacos, aumentando assim a vida da ferramenta, e consequentemente, a taxa de produção, quando comparado com o corte a seco (Toenshoff et al, 2000). No entanto, o uso de ferramentas em cBN e cerâmicas que possuem grande resistência ao calor, têm permitido a usinagem a seco nos materiais endurecidos, reduzindo consideravelmente os custos de compra, armazenamento e descarte do fluido de refrigeração. Segundo Abrão et al (1996), as forças de corte na usinagem de materiais endurecidos são $30 \%$ a $60 \%$ maiores do que aquelas desenvolvidas quando se usina materiais de menor dureza, o que obriga uma escolha cuidadosa do tipo da geometria da ferramenta de corte. A precisão geométrica nas tolerâncias de usinagem para o torneamento em material endurecido ainda se mostram muito dependentes da condição e estrutura da máquina empregada, porém de acordo com Almeida e Abrão (2001) e Abrão (2005), a utilização de tornos com estruturas convencionais possibilita o alcance de tolerâncias na faixa ISO IT6.

A ação da ponta da ferramenta contra a peça durante o torneamento gera deformação plástica no material usinado na região de corte. Além do atrito nas interfaces da ferramenta-cavaco e cavaco-peça, são geradas variações térmicas de tal nível que provocam transformações metalúrgicas na superfície e sub-superfície da peça usinada (Brinksmeier et al. 1992). Uma camada fina de martensita, conhecida como camada branca, pode ser gerada pelas altas temperaturas e rápido resfriamento na região de corte, causando uma sobre-têmpera do material da superfície da peça (Toenshoff, 1994). O desgaste da ferramenta é um dos principais fatores na formação desta microestrutura nos aços usinados, ao induzir o aumento da temperatura na região de corte (Liu e Barash,1976 e Fleming et al, 1998).

Para quantificar a integridade superficial do componente após o torneamento em material endurecido foram executadas investigações sobre tensões residuais, zonas de camada alterada e rugosidade da superfície como uma função dos parâmetros de usinagem. A caracterização funcional das superfícies obtidas, tais como capacidade de carga e capacidade de retenção de fluídos lubrificantes foi 
analisada através de parâmetros obtidos do mapeamento tridimensional da superfície, e, comparadas com resultados de outros experimentos incluindo experimentos com peças retificadas.

Atualmente dispomos de vários métodos para medir as tensões residuais, tais como: difração de raios- $X$, ultra-som e eletromagnéticos, $O$ mais usado nos meios acadêmicos e industriais é a difração de raios- $X$, devido ao seu alto grau de desenvolvimento tecnológico (Delijaicov, 2004). Outra técnica utilizada na análise de tensões residuais é a extensometria via strain-gages (medidores de deformações) através do Método do furo cego, que neste trabalho é utilizada por ser simples, acessível e barata.

Fenômenos de superfície ocorrem em três dimensões (3-D). Por exemplo, a interação entre duas superfícies em contato realiza-se no âmbito de toda a interface, a interação entre uma superfície áspera e o fluxo de um fluído também ocorre tridimensionalmente (Batalha e Stipkovic, 2001). Stout et al (1993), descreveram e análise de superfícies baseadas em medição 3-D como abordagem mais realista e eficaz para a compreensão de fenômenos superficiais. Uma medição por perfilometria bi-dimensional (2-D) apresenta a rugosidade da superfície em um plano somente, é eficiente onde a superfície é estritamente uniforme e os padrões são perpendiculares ao plano de medição perfilométrico. Contudo tal suposição gera duvidas, pois em um processo real de usinagem muitos são os parâmetros que podem causar distorções na condição final da superfície. A perfilometria 2-D é útil, por ser um método de aquisição de dados mais veloz, no caso em que já é conhecido o comportamento da superfície, e o erro em função da generalização do perfil obtido pela medição 2-D para todo o restante da superfície não causa perda de desempenho no componente. Para este trabalho, visando obter uma caracterização isenta de suposições e tendências, a medição da topografia 3-D da superfície foi utilizada por ser a mais indicada para estudos científicos. 


\subsection{Objetivo}

A intenção deste trabalho é contribuir com informações sobre a integridade superficial resultante do torneamento de componentes mecânicos, fabricados em aço ABNT 8620 cementados com camada média de $1.0 \mathrm{~mm}$ e posteriormente temperados e revenidos para dureza de 660-760HV (aproximadamente 58-62HRC).

Para quantificar a integridade superficial do componente após o torneamento em material endurecido serão executadas investigações sobre:

- Tensões residuais, com o intuito de identificar grandezas e condição (tração ou compressão) como função dos parâmetros de usinagem;

- Caracterização funcional das superfícies obtidas, tais como capacidade de carga e capacidade de retenção de fluídos lubrificantes que será analisada através de parâmetros obtidos do mapeamento tridimensional da superfície;

- Camada branca, sua existência e situação em função dos parâmetros de usinagem;

- Comparações com resultados de outros experimentos incluindo experimentos com peças retificadas. 


\subsection{Organização da Dissertação}

Visando uma melhor compreensão dos problemas discutidos durante o desenvolvimento do experimento, esta dissertação foi dividida como segue:

No Capítulo 1, são apresentadas as motivações, os objetivos e a descrição deste trabalho.

No Capítulo 2 é apresentada a Revisão Bibliográfica utilizada na pesquisa deste trabalho abordando os seguintes conceitos:

- Integridade superficial para peças usinadas;

- Processo de cementação utilizado no tratamento de endurecimento das amostras avaliadas;

- Teoria da usinagem, formação de cavaco e desgaste da ferramenta no processo de torneamento de materiais endurecidos;

- Procedimentos de medição da topografia de superfície bem como toda descrição dos parâmetros;

- Processos de medição de tensão residual.

No Capítulo 3 são apresentados o Procedimentos executados no Experimento.

No Capítulo 4 são apresentados os Resultados obtidos.

No Capítulo 5 são apresentadas as Discussões sobre os resultados.

No Capítulo 6 são apresentadas as Conclusões relativas a este trabalho.

No Capítulo 7 são apresentadas as Sugestões para trabalhos futuros.

No Capítulo 8 são apresentadas as Referências Bibliográficas utilizadas neste trabalho.

No Capítulo 9 são apresentados os Anexos utilizados no trabalho. 


\section{REVISÃO BIBLIOGRÁFICA}

\subsection{Integridade Superficial}

Um processo de manufatura produz uma superfície a ser caracterizada em termos de topografia e material. Estas influenciam o desempenho funcional da superfície. Se a superfície for de desbaste seu desempenho funcional provavelmente será baixo. Se a condição de tensão residual não for de compressão seu desempenho funcional também será baixo, como observado por vários autores (Toenshoff et al, 2000, Guo e Barkey, 2004, Shaw, 2007, Rech et al, 2008, Grzesik, 2008).

Segundo Field e Kahles (1972), para especificar e manufaturar uma superfície com um alto grau de integridade é necessário a aplicação interdisciplinar de tópicos como a metalurgia, usinagem e testes mecânicos. A Integridade Superficial é obtida pelo uso de processos de manufatura cuidadosamente selecionados e controlados com base em avaliações de funcionalidade e necessidades específicas que a peça usinada deve apresentar.

O termo Integridade Superficial, descreve a ligação entre os processos, aspectos da superfície e desempenho. Este termo visa definir o estado da superfície em função de seu provável desempenho em serviço. Segundo Griffiths (2001), o termo Integridade Superficial (IS) foi descrito como o valor topológico, mecânico, químico e metalúrgico de uma superfície usinada e seu o relacionamento ao desempenho funcional.

O termo Integridade Superficial, ao contrário do termo Tecnologia de Superfície, está ligado ao ambiente onde o componente será utilizado. Ele foi proposto para ressaltar esta ligação entre o processo, desempenho e posteriormente para dar uma indicação da provável confiabilidade e aspecto genuíno de uma superfície manufaturada. O termo Integridade Superficial necessita de quantificação, para isso, uma família de definições foi criada para descrevê-lo, e posteriormente, associá-lo ao seu provável desempenho em serviço. A Figura 1 ilustra estas definições. 


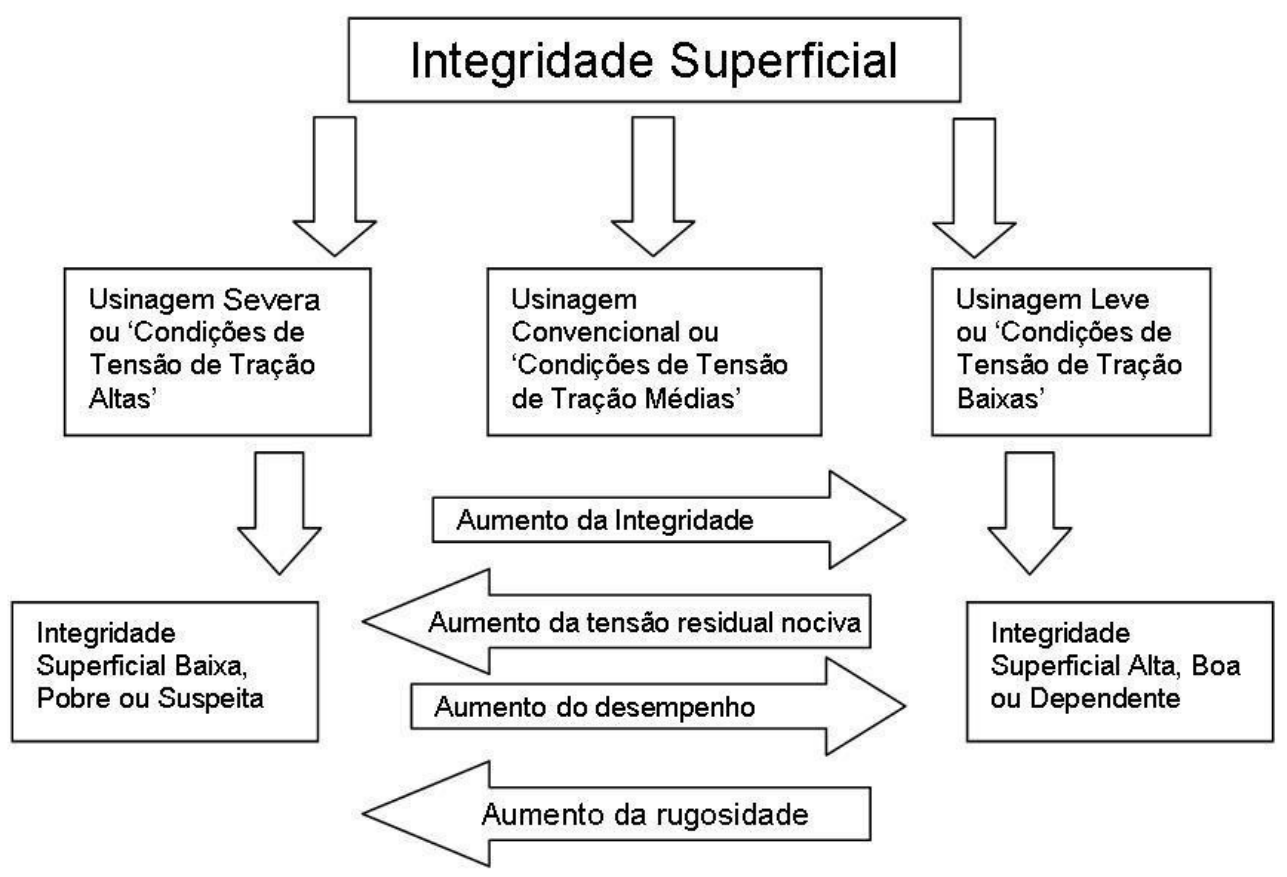

Figura 1. Definições de Integridade Superficial (Griffiths, 2001).

\subsubsection{Condições de Usinagem}

As condições de usinagem como velocidade, avanço, profundidade de corte, estado da ferramenta e lubrificação, empregadas no processo de usinagem podem variar significativamente. Elas afetam não somente a taxa de produção, mas também a integridade da superfície. Para ilustrar os extremos das taxas de produção usados na indústria, palavras como Alta e Baixa são geralmente usadas. Para os extremos da integridade superficial, as palavras relativas são Severa e Leve (Griffiths, 2001).

Condição de usinagem severa é aquela onde a taxa de produção é maximizada e não existe controle das ferramentas e do lubrificante. Usinagem severa é associada com:

- Uso de altas velocidades de corte, avanço e profundidade de corte;

- Uso de ferramentas que estão no fim de suas vidas, desgastadas e sem corte;

- Lubrificação inadequada e/ou inapropriada, ou sem lubrificação;

- Uso de máquinas ferramentas velhas, desgastadas e sem rigidez. 
Portanto, usinagem severa gera calor, altas tensões e alta taxa de carregamento na superfície. Em contrapartida, nas usinagens leves, um extremo cuidado com as condições é tomado, produzindo pouca geração de calor e alterações mínimas na superfície. Usinagem leve é associada com:

- Uso de velocidades de corte, avanço e profundidades de corte que promovam maior da vida da ferramenta;

- Uso de ferramentas afiadas;

- Lubrificação abundante e apropriada;

- Máquinas ferramentas precisas e rígidas operando sem vibrações.

Portanto, usinagens leves geram pouco calor e produzem uma superfície com menores valores de tensão de tração, ou totalmente isentas desta condição.

Uma camada termicamente afetada irá influenciar na fadiga, corrosão, corrosão por tensão, resistência, desgastes e falha. Na maioria dos casos registrados na literatura, a camada de material termicamente afetada (CMTA) exerce uma influência negativa no desempenho funcional e geralmente são indesejáveis em questão de integridade superficial (Griffiths, 2001).

Existe uma clara diferença entre condições de usinagem severa e leve, no entanto, em alguns casos as diferenças são obscuras, pois é possível escolher condições que combinam altas taxas de remoção com boa integridade superficial. Rech e Moisan (2003) estudaram a influência das condições de usinagem em engrenagens de aço cementado e observaram que existem determinadas condições de corte que não devem ser empregadas para produção em larga escala.

Outro termo utilizado em condições de operação é usinagem Convencional (Griffiths, 2001), que difere de ambas as condições, leve e severa. Leve e severa referem-se aos dois extremos da usinagem, convencional refere-se às condições normalmente utilizadas nos processos de manufatura onde as recomendações dos fabricantes são seguidas e as condições de boas práticas durante a usinagem são observadas. Espera-se que a integridade superficial do produto resultante de usinagens em condições convencionais esteja sempre entre os dois extremos, leve e severa, não necessariamente em processos que tendem a apresentar mecanismos térmicos, como é o caso de usinagem na presença de desgaste da ferramenta. Toenshoff et al (2000) apresentaram relações entre o aumento da área de contato da ponta da ferramenta, devido ao desgaste, e a energia dissipada por unidade de 
área, neste mesmo estudo é correlacionado o estado de tensão residual resultante que tende à tensão de tração na presença da temperatura. Outros autores (Poulachon et al, 2001, Pavel et al, 2005) estudaram os efeitos negativos do desgaste da ferramenta na integridade superficial na forma de análise da rugosidade.

\subsubsection{O Evento Unitário do Processo de Usinagem}

Todo o processo de usinagem remove camadas da superfície da peça de uma forma ou de outra. Isto pode se dar na forma de remoção de um cavaco em fita da superfície, como no caso do torneamento, na forma de pequenas remoções individuais, no caso da eletro-erosão ou na forma de dissolução de toda a superfície exposta, a usinagem química. Para qualquer processo de manufatura empregado, o método de remoção irá consistir em um único Evento Unitário (Griffiths, 2001), o qual possui seus próprios mecanismos que definem a Integridade Superficial (IS). O Evento Unitário irá consistir de mecanismos químicos, mecânicos e térmicos que separados ou combinados removem material e em função de vários parâmetros inerentes ao processo gera uma integridade superficial, como mostra a Figura 2.

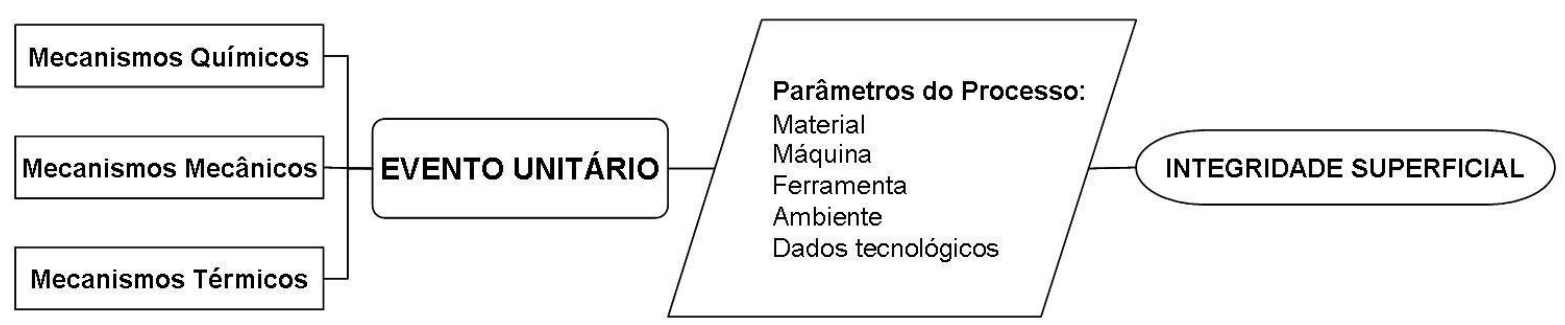

Figura 2. Influências na geração de uma Integridade Superficial (adaptado de Griffiths, 2001).

O evento unitário é composto de vários mecanismos geradores dentro do processo de usinagem. A consideração do mecanismo do evento unitário irá propiciar um entendimento de como é a superfície e o motivo que a faz ser assim. Irá, também, permitir que as superfícies possam ser projetadas ou desenvolvidas para apresentar desempenho ou características em particular. 
Os mecanismos geradores do evento unitário podem ser divididos em três tipos: mecânico, térmico e químico. Estes mecanismos estão sempre presentes, em maior ou menor grau, em todos os processos de usinagem. Muitas vezes não existe uma clara distinção entre eles.

A Figura 3 mostra as cinco classes em ordem crescente de densidade de energia transferida à superfície. Quanto maior a densidade de energia transferida para a superfície, maior a probabilidade de se obter integridade superficial de baixa qualidade.

Um diagrama esquemático do balanço energético também é visto na Figura 3, sendo possível notar que o processo químico ocorre em todas as classes em maior ou menor proporção.

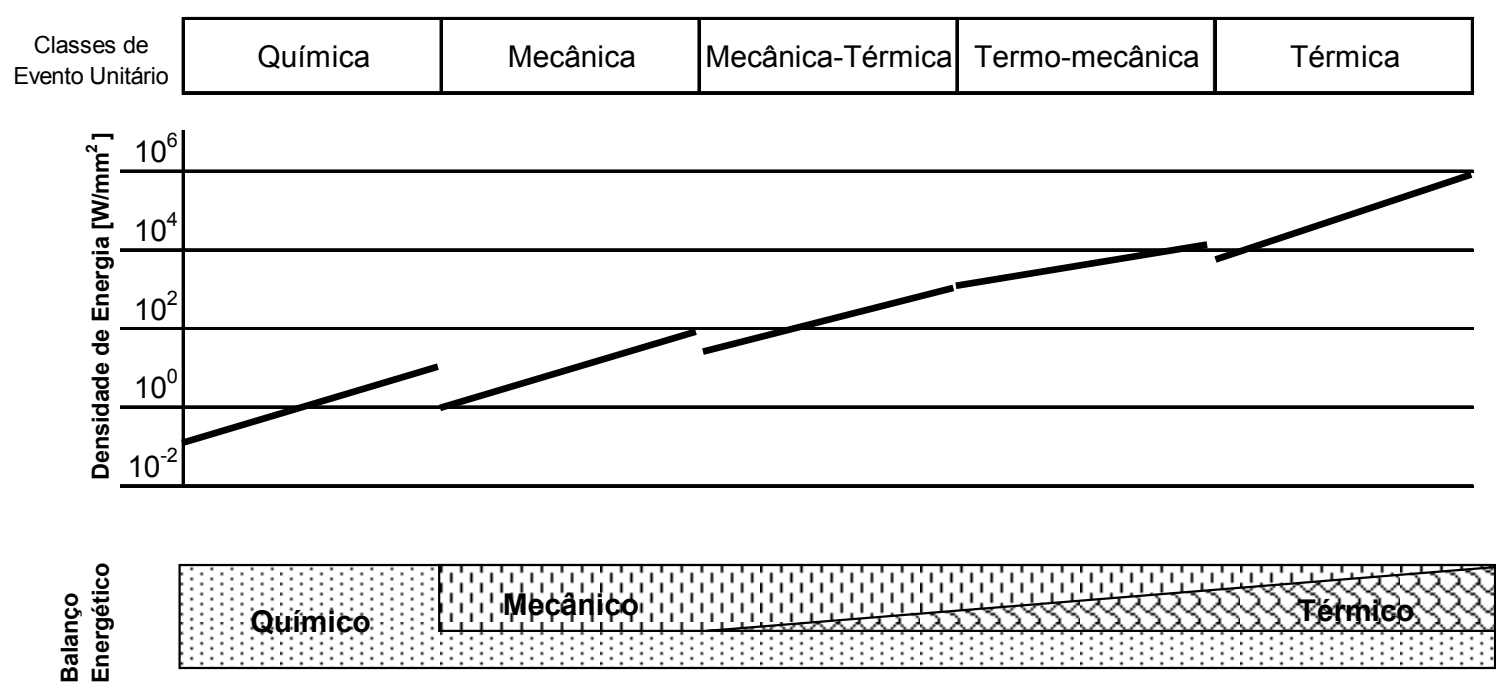

Figura 3. As cinco classes de processos arquétipos de usinagem (Griffiths, 2001).

Na Figura 4 Toenshoff et al (2000) apresentaram um diagrama correlacionando o evento unitário do torneamento e as forças de corte envolvidas em função da vida da ferramenta para o aço ABNT 5115 (16 MnCr 5) endurecido com 700 a 750 HV (60 a $62 \mathrm{HRC}$ ). A ferramenta utilizada foi uma SNG120416 de $\mathrm{Al}_{2} \mathrm{O}_{3} / \mathrm{TiC}$ com velocidade de corte $V_{c}=145 \mathrm{~m} / \mathrm{min}$, avanço $\mathrm{f}=0.1 \mathrm{~mm} / \mathrm{rot}$, profundidade de corte $a_{p}=0.2 \mathrm{~mm} \mathrm{e}$ usinagem a seco. 


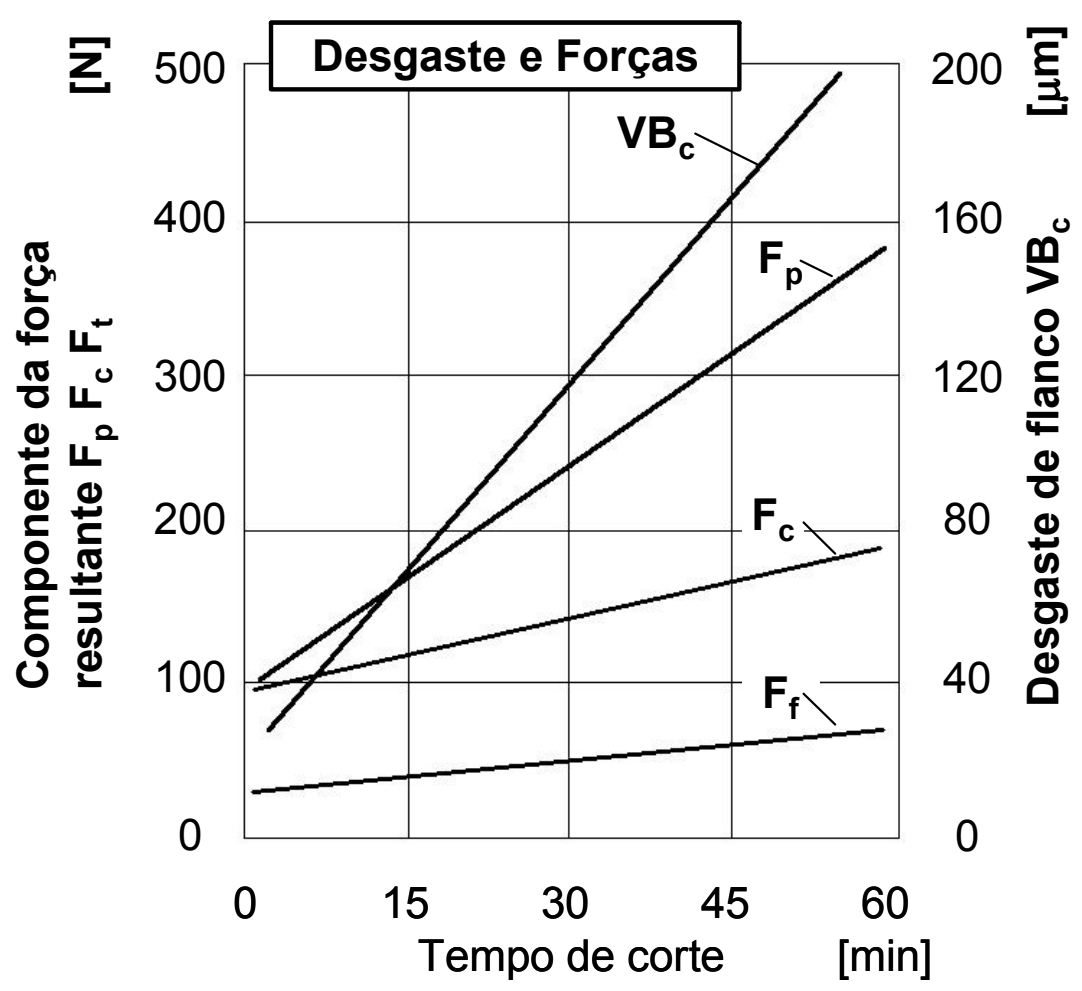

Figura 4. Relações entre desgaste de flanco (VBC) e forças de corte (Toenshoff et al, 2000).

Na Figura 4 é possível perceber que as forças de corte, especialmente a força passiva $\left(F_{p}\right)$ aumentam devido ao desgaste natural da ponta da ferramenta em função do tempo de usinagem. É possível observar haverá uma mudança no balanço energético do mecanismo de corte que na condição inicial é mecânicatérmica para termo-mecânica (vide Figura 3) possibilitando o aparecimento de integridade superficial de baixa qualidade.

\subsubsection{Camadas de Material Alteradas - CMA}

O evento unitário irá influenciar a superfície e a subsuperfície de várias maneiras. As mudanças na subsuperfície irão gerar as Camadas de Material Alteradas (CMA) que irão consistir em uma variedade de mudanças dependentes do mecanismo de geração do evento unitário: 
- Camada de material quimicamente alterada (CMQA), que é causada por mudanças químicas superficiais que fazem parte do processo de manufatura do evento único ou aquelas causadas pela exposição ao ambiente/atmosfera;

- Camada de material mecanicamente alterada (CMMA), que consiste em deposições, ressaltos, riscos e deformação plástica;

- Camada de material termicamente alterada (CMTA), que consiste em transformações de fases, trincas e retempera;

- Camada de material alterada por tensões (CMAT), que resultam das tensões residuais da combinação de eventos térmicos e mecânicos da manufatura.

A CMA sofre influência provinda do evento unitário de usinagem e se encontra imediatamente abaixo da superfície usinada. A Figura 5 apresenta um modelo esquemático das três zonas mais distintas e comumente observadas nos aços.

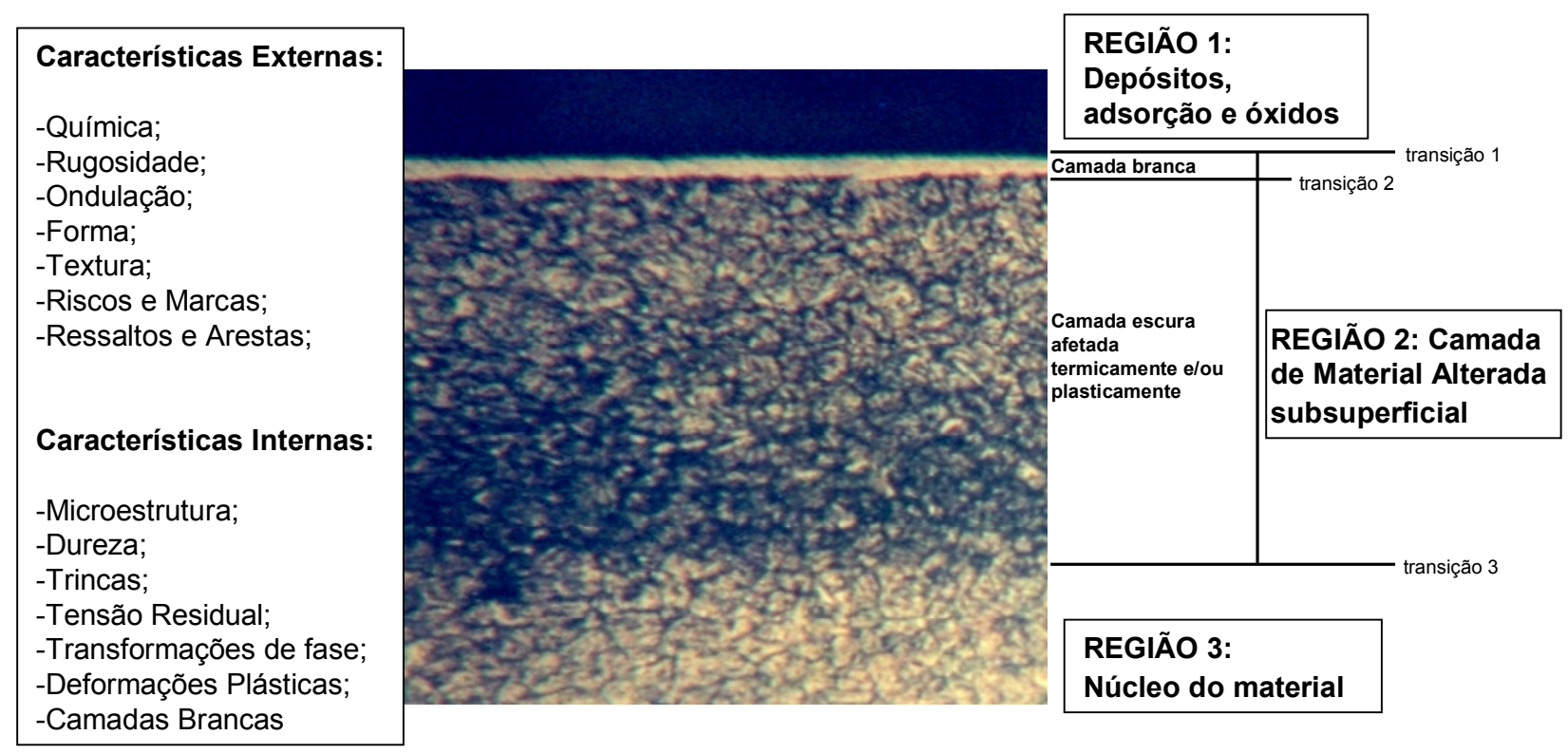

Figura 5. Seção esquemática de uma superfície de aço usinada.

Em primeiro lugar está a Região 1, que está em contato e reage direto com o ar. Logo abaixo está a Região 2 que foi alterada ou sofreu alguma influência proveniente do evento unitário de usinagem e por terceira e última a Região 3 do núcleo. Não existe uma linha divisória clara entre a Região 2 e Região 3 (vide linha "transição 3" na Figura 5), esta se dá por uma transição gradual. 
A CMA se caracteriza por mudanças de dureza, química, metalúrgica, condição das tensões residuais e deformação plástica, e influenciam o desempenho funcional do produto. Uma ou outra pode predominar em função do processo e condições estabelecidas, melhorando ou piorando em função do grau de intensidade.

\subsubsection{Martensita não Revenida - MNR e Camada Branca - CB}

O termo Martensita não Revenida (MNR) refere-se às camadas endurecidas criadas pelos processos de usinagem, que convertem a martensita para o estado de não revenido (Field e Kahles, 1971). O termo Camada Branca (CB) é um termo genérico e refere-se às camadas altamente endurecidas quando comparadas ao núcleo do material. Seu aspecto é branco e sem características quando vistas ao microscópio. Existem ao menos seis tipos de camadas brancas identificadas, que dependem fortemente do balanço termo-mecânico e químico do processo, taxa de aquecimento/resfriamento e etc. Geralmente pode-se dizer que a CB é uma forma particular de MNR.

Em eventos unitários puramente térmicos como a eletro-erosão em desbaste ou acabamento, por exemplo, a CB é formada. Em processos de remoção de material com ferramenta afiada existem algumas situações que podem gerar $C B$, como a retificação por exemplo. A Figura 6 mostra uma típica CB/MNR produzida por evento unitário de retificação em condição severa de aço-liga SAE H13 (Wnr 1.2344) nitretado.

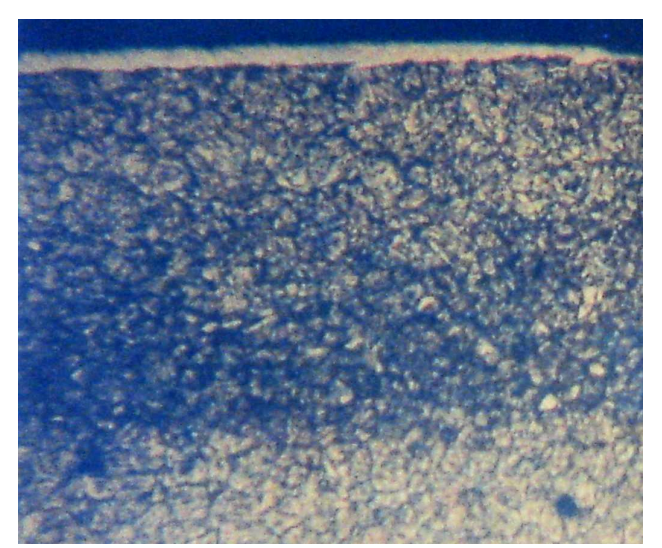

Figura 6. Camada branca com espessura média de $7 \mu m$ gerada por retificação em condição severa (Farias, 2007). 
A camada branca é associada ao processo de retificação já há muito tempo. Sob condições severas de desbaste a queima da retificação produz CB e MNR reduzindo o desempenho da peça quanto à resistência à fadiga. $O$ fluxo de calor para peça na retificação é muito maior quando comparada à usinagem com ferramenta, o que aumenta a incidência de $\mathrm{CB}$, ao contrário se diz da usinagem com ferramenta, onde o fluxo de calor para peça é reduzido.

Hashimoto et al (2006) investigaram a resistência à fadiga do aço rolamento ABNT 52100 endurecido por tempera e usinado em processos distintos de retificação $(R)$ e de torneamento $(T)$ em material endurecido. A Figura 7 apresenta seus resultados. A condição de torneamento apresentou o dobro de ciclos até a fadiga mostrando que é possível melhorar o desempenho do componente com a utilização do processo de torneamento em material endurecido.

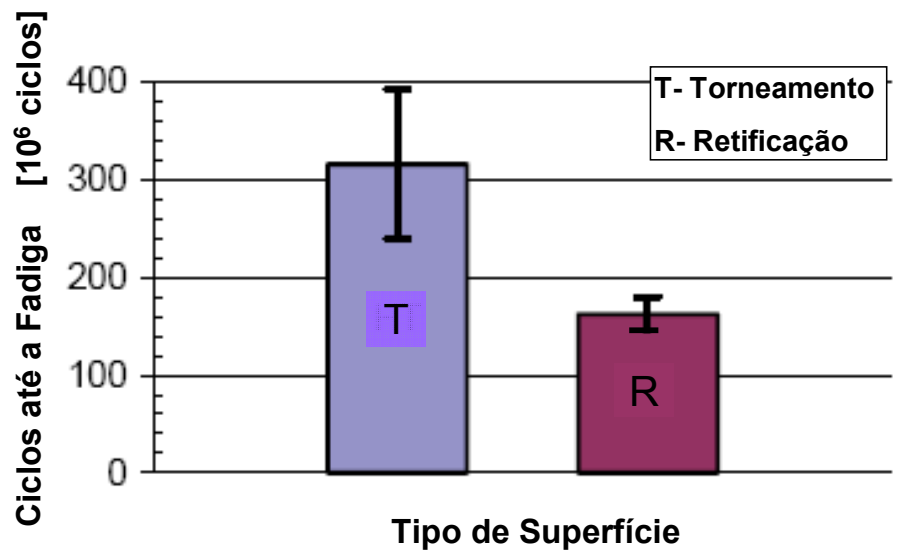

Figura 7. A influência do processo de usinagem na fadiga (Hashimoto et al, 2006).

A CB e MNR são geralmente prejudiciais à integridade superficial da peça. Reduzem a resistência à fadiga e estão associados ao acúmulo de tensão residual de tração na superfície da peça.

Schwach e Guo (2005) mostraram como camadas termicamente afetadas podem influenciar o bom desempenho da vida útil de um componente (Figura 8). Em seu estudo, relacionaram a queda da vida útil, no teste de contado de rolamento de peças em aço ABNT 52100 nas seguintes condições apresentadas na Tabela 1: 
Tabela 1. Condições de usinagem do aço ABNT 52100 (Schwach e Guo, 2005).

\begin{tabular}{|c|c|c|c|c|}
\hline Condição & $\mathbf{V}_{\mathbf{c}}$ [m/min] & $\mathbf{f}[\mathbf{m m} / \mathbf{r o t}]$ & $\mathbf{a}_{\mathbf{p}}[\mathrm{mm}]$ & $\mathbf{V B}[\mathrm{mm}]$ \\
\hline CB-1 & 169,2 & 0,0254 & 0,254 & 0,7 \\
\hline CB-2 & 169,2 & 0,0254 & 0,254 & 0,4 \\
\hline SC-1 & 106,8 & 0,1020 & 0,254 & 0 \\
\hline SC-2 & 106,8 & 0,0254 & 0,254 & 0 \\
\hline
\end{tabular}

Onde CB significa condição usinada com camada branca, SC significa condição usinada sem camada branca e os índices 1 e 2 significam variação nas condições de corte.

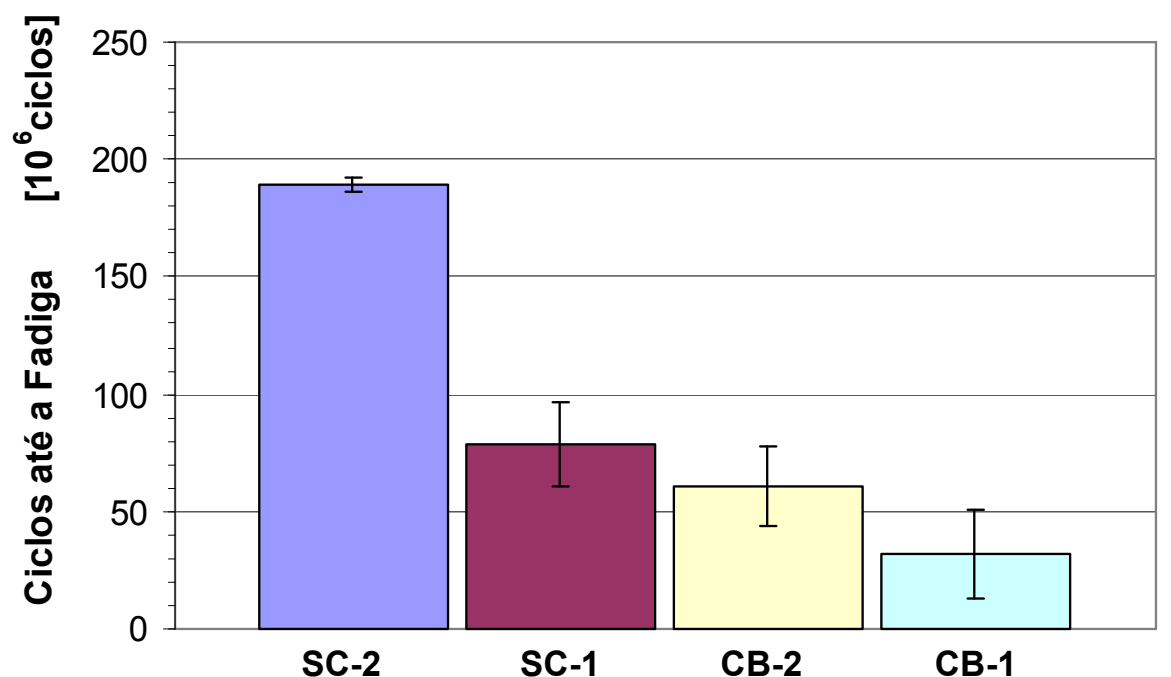

Figura 8. Comparação da vida útil em teste de rolamento de contato para aço ABNT 52100 (Schwach e Guo, 2005).

Nota-se pela Figura 8 que as condições de torneamento sem camada branca (SC-1 e SC-2) são melhores do que com camada branca. A variação dos dados de corte (sem que haja o aparecimento de camada branca) influencia fortemente a condição de resistência à fadiga, pois a condição sem camada branca (SC-2) apresentou mais do que o dobro de ciclos até a fadiga. É importante observar que determinadas condições de corte são inviáveis para produção em larga escala, portanto o balanceamento entre um bom desempenho do componente e uma boa condição de produção deve ser almejado. 


\subsubsection{Martensita Sobrerevenida - MSR}

Em geral os aços são empregados na condição temperados e revenidos, porém, se algum outro aquecimento exceder a temperatura de revenimento, o material perderá dureza.

O processo de usinagem gera calor que é transmitido à peça, e a rápida refrigeração que pode ocorrer no evento (por liquido refrigerante ou outro), provoca o endurecimento da camada superficial (causando a MNR); no entanto a subcamada superficial não é resfriada na mesma taxa, e portanto, são revenidos novamente causando uma perda de dureza na camada subsuperficial. Esta camada é nomeada Martensita Sobrerevenida (MSR).

Segundo Abrão e Aspinwall (1996), que executaram investigações de dureza em camadas subsuperficiais de peças temperadas e usinadas em diversas condições, foi identificada variação no perfil de dureza superficial nas amostras usinadas pelo processo de torneamento endurecido. Notou-se que a uma profundidade de aproximadamente $5 \mu \mathrm{m}$ houve uma queda de dureza de até $200 \mathrm{HV}$ em relação à dureza nominal (aproximadamente $800 \mathrm{HV}$ ) anterior ao processo de usinagem.

Eventos térmicos durante a usinagem criam três camadas distintas, a primeira composta por MNR ou CB, a segunda composta por MSR ou Camada Escura (ver Figura 5) e a terceira que é o núcleo da peça em questão. A camada MNR é frágil e susceptível a trincas, a camada MSR possui uma menor dureza e, portanto uma menor resistência ao escoamento provocando sérias implicações quanto ao desempenho do componente.

Schwach e Guo (2005) apresentaram em seus estudos os perfis de durezas obtidos de ensaios com condições de presença de CB e ausência. A Figura 9 apresenta os resultados nas diversas condições, por eles avaliadas no aço ABNT 52100, as condições utilizadas encontram-se na Tabela 1, onde CB significa condição usinada com camada branca, SC significa condição usinada sem camada branca e os índices 1 e 2 significam variação nas condições de corte. 
Nota-se que na profundidade de aproximadamente $7 \mu \mathrm{m}$ para a condição com camada branca (CB-1 e CB-2), houve uma variação de dureza de até $800 \mathrm{HV}$ em relação à condição sem camada branca (SC-1 e SC-2). Na Figura 9 estão sinalizadas as regiões de camada branca com durezas de $1200 \mathrm{HV}$, camada escura com durezas de $400 \mathrm{HV}$ e núcleo com durezas de aproximadamente 900HV. Estas regiões são distintas somente nos casos de condições com camada branca (CB-1 e CB-2) devido à severidade da condição de corte imposta no processo de usinagem.

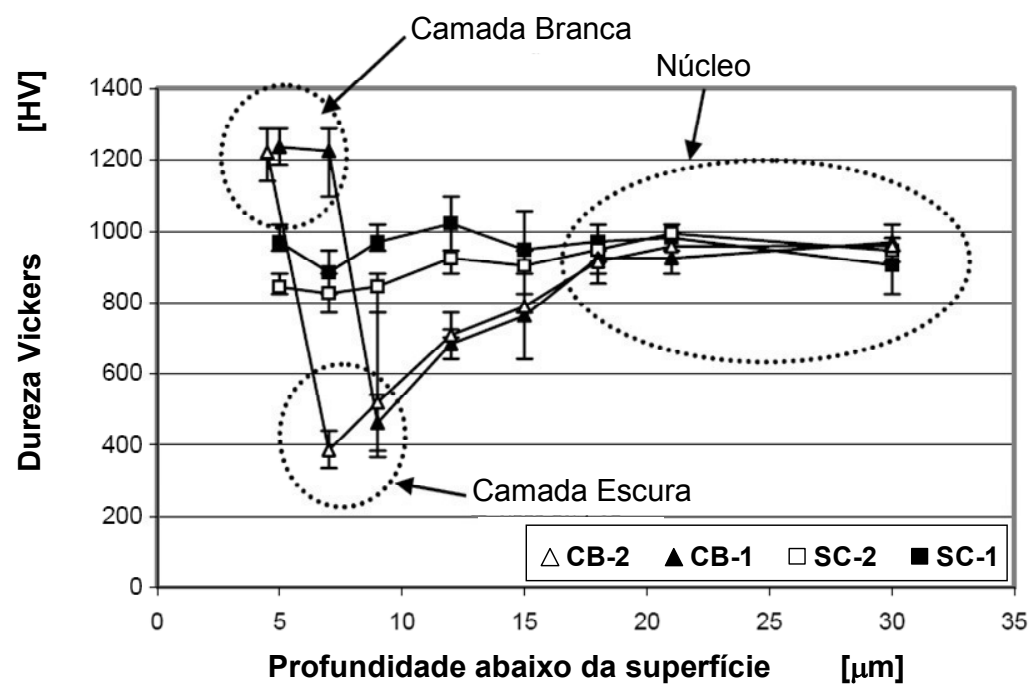

Figura 9. Perfil de durezas em camadas subsuperficiais (Schwach e Guo, 2005).

Como visto na Figura 8, podemos associar a queda no desempenho da resistência à fadiga dos componentes com esta grande variação no gradiente de durezas das amostras com camada branca (CB-1 e CB-2).

\subsubsection{Deformação Plástica}

A deformação plástica ocorre quando as forças do evento unitário da usinagem excedem a tensão média de escoamento do material, de tal modo, que a estrutura do material é deformada. Se a deformação de cisalhamento na superfície é severa aos grãos adjacentes à superfície, nenhum tipo de estrutura pode ser definido. $A$ isto se dá o nome de camada branca de deformação plástica, Figura 10. Se o processo de deformação for contínuo, trincas podem ocorrer. 


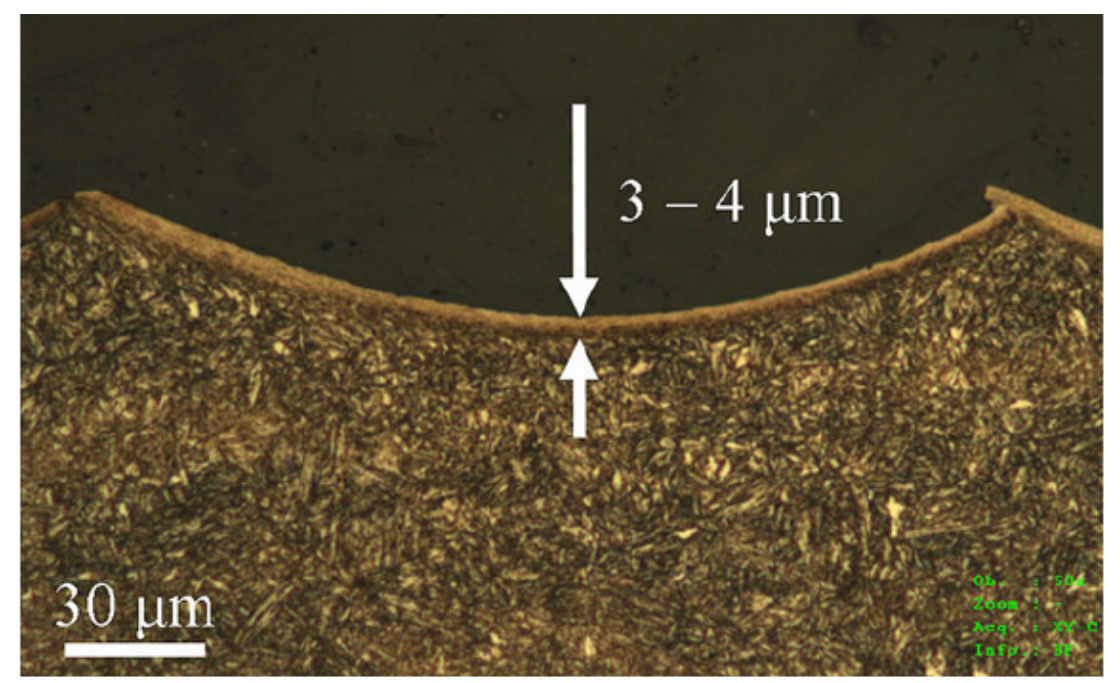

Figura 10. Zona de deformação plástica localizada em subsuperficie usinada (Javidi et al, 2008).

Javidi et al (2008) analisou a estrutura do material ABNT 4340 tratado termicamente para dureza de aproximadamente $350 \mathrm{HV}$ e usinado no processo de torneamento. A Figura 11 apresenta uma micrografia com microscopia eletrônica de varredura (MEV) da área subsuperficial onde se pode observar a deformação provocada pelo processo. A região $\mathbf{A}$ indica a área onde não é possível distinguir a estrutura dos grãos originais, e logo abaixo é possível identificar a deformação plástica sofrida pela estrutura da durante o processo.

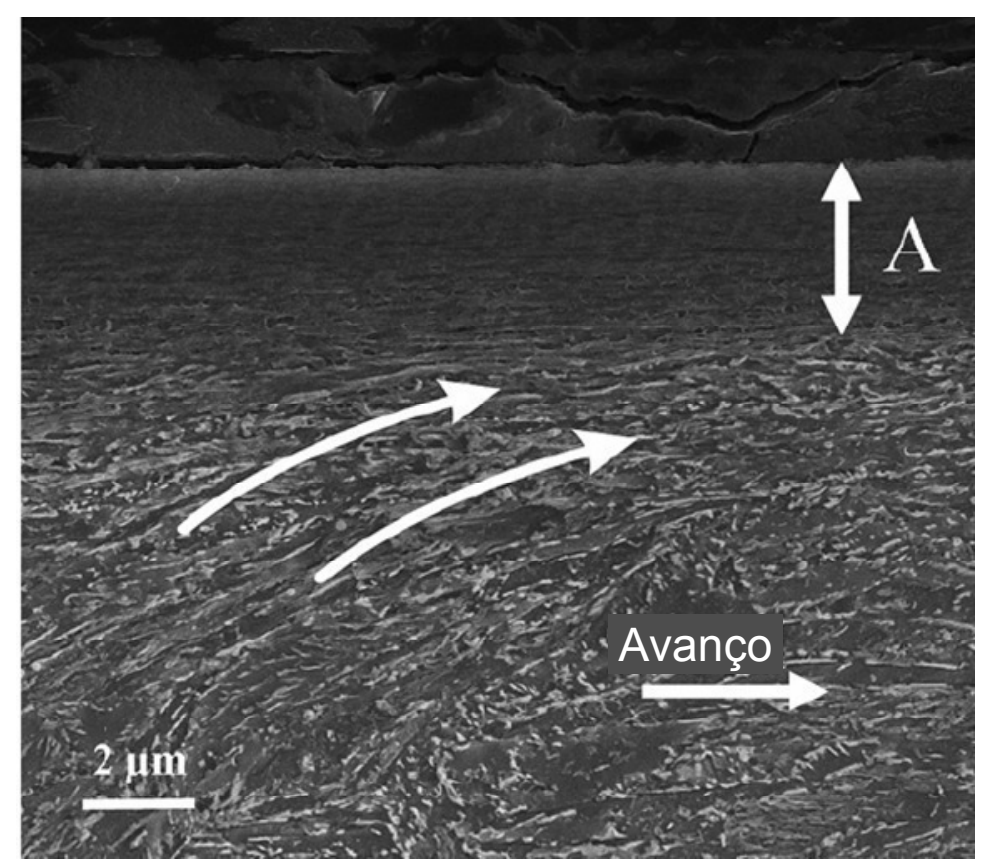

Figura 11. Micrografia MEV da zona de deformação plástica localizada em subsuperficie usinada (Javidi et al, 2008). 
Outro exemplo de deformação plástica típica é mostrado na Figura 12 (a), o processo usado foi o de furação com broca rotativa, e a secção é transversal ao eixo do furo. O grão distorcido próximo à superfície é evidente devido a uma severa deformação causada pela broca. Próximo à superfície, os grãos alongados são virtualmente paralelos à superfície indicando altos níveis de tensão Figura 12 (b).

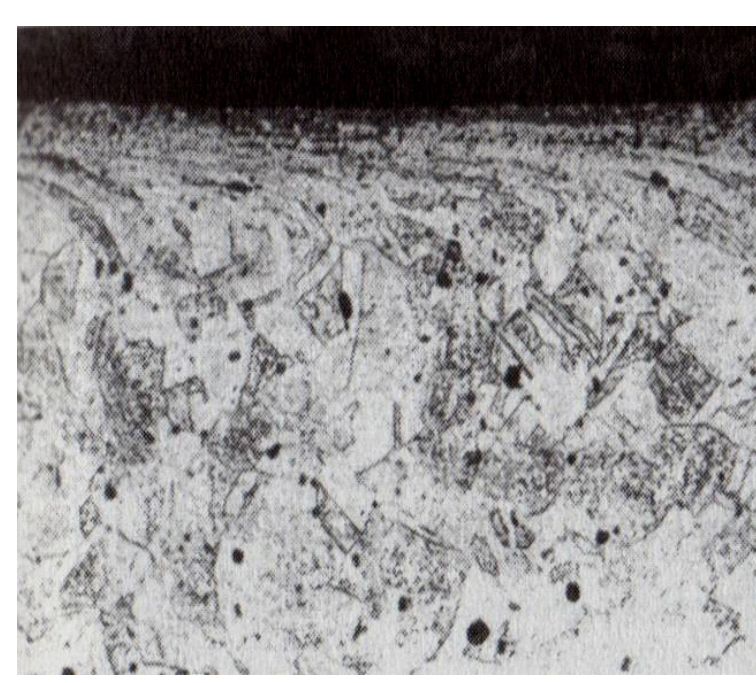

(a)

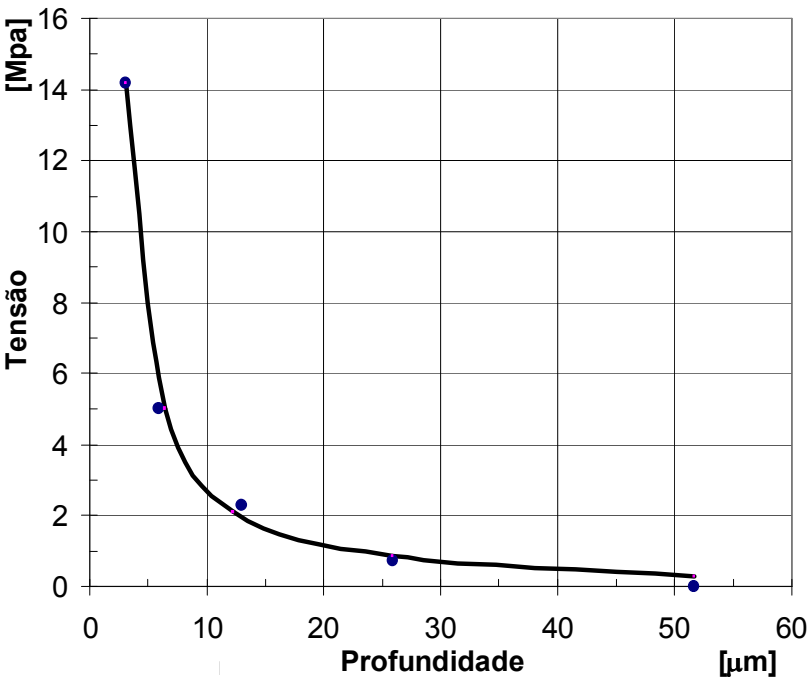

(b)

Figura 12. Seção radial por um furo em cobre (a) e sua tensão associada (b) (Griffiths, 2001).

Tem-se discutido que em tais processos de deformação duas camadas são evidentes (Turley et al, 1974 apud Griffiths, 2001). A primeira camada, adjacente à superfície, foi altamente distorcida e muito pouco ou nenhuma estrutura de grãos original permanece evidente, é chamada "camada fragmentada". Abaixo desta camada está a "camada deformada" que foi submetida à deformação plástica, porém, a estrutura original ainda é evidente. Estas duas camadas juntas compõem a CMA de deformação plástica. A profundidade da CMA é razoavelmente constante na superfície durante um evento unitário de usinagem, entretanto, a distorção pode ser tão extrema que a camada fragmentada aparece amorfa quando observada no microscópio. Porém, na realidade, pode consistir de subgrãos altamente distorcidos. Esta camada fina de material também pode ser chamada de $C B$, porém não deve ser confundida com a camada branca térmica. 
Detalhes de uma camada deformada causada pelo processo de torneamento interno em um aço inoxidável estão ilustrados na Figura 13 (a) e (b). Na Figura 13 (a) a secção é transversal ao eixo do furo, e na Figura 13 (b) a secção é paralela ao eixo do furo. A profundidade total da deformação plástica (fragmentada mais a deformada) é aproximadamente $70 \mu \mathrm{m}$.

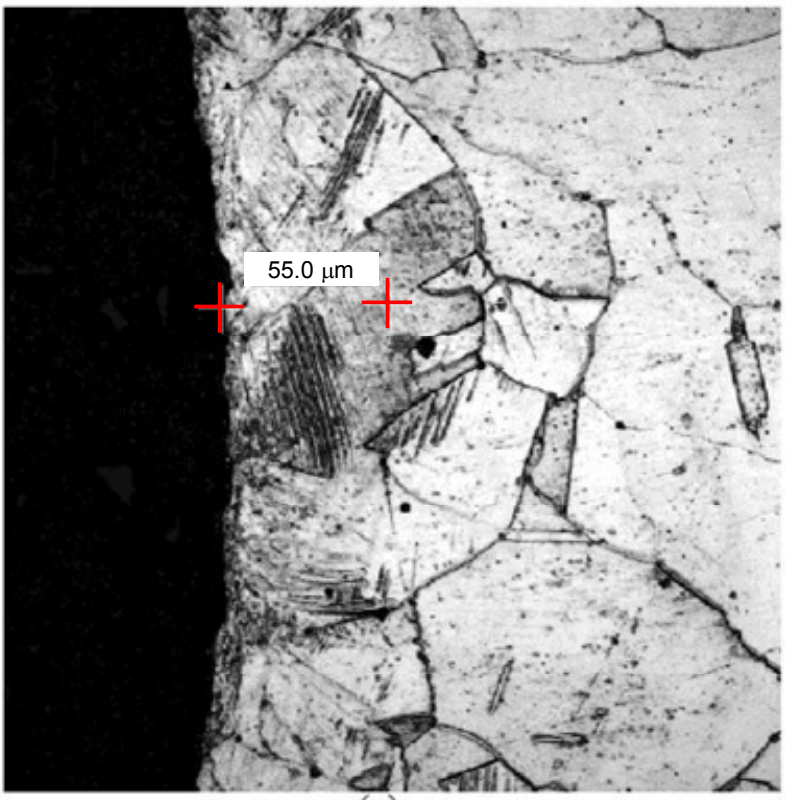

(a)

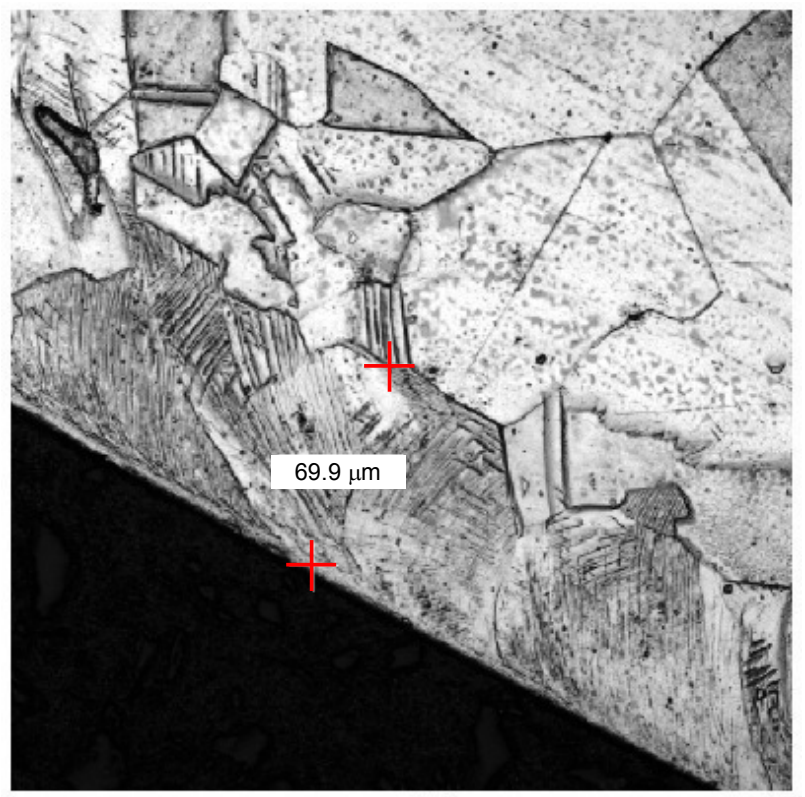

(b)

Figura 13. Zona deformada em camada subsuperficial de um aço inoxidável (a) secção transversal, e (b) seç̧ão paralela ao eixo do furo (Marin et al, 2003).

A micrografia da Figura 14 mostra um tipo diferente de CB produzida por torneamento em condições severas "controladas". Neste caso a CB possui uma dureza de $1050 \mathrm{HV}$ em comparação ao núcleo com 330HV. A ferramenta utilizada para produzir esta superfície era afiada, porém um desgaste artificial foi produzido na face de saída da ferramenta, o que gerou um atrito na superfície da peça. Neste caso o atrito provocou uma deformação plástica por tensão de compressão.

Este tipo de deformação plástica resulta em uma tensão residual de compressão benéfica que aumenta o limite de fadiga e o desempenho da peça como um todo. Processos como o jateamento com esferas, causam deformação plástica na superfície que por sua vez causam tensão de compressão. Em adição a estes processos que causam "modificações superficiais", existem outros processos de usinagem que também causam endurecimento superficial, como por exemplo, furação, fresamento e torneamento, porém, somente em baixas velocidades de corte, pois em altas velocidades o efeito térmico se torna dominante. 


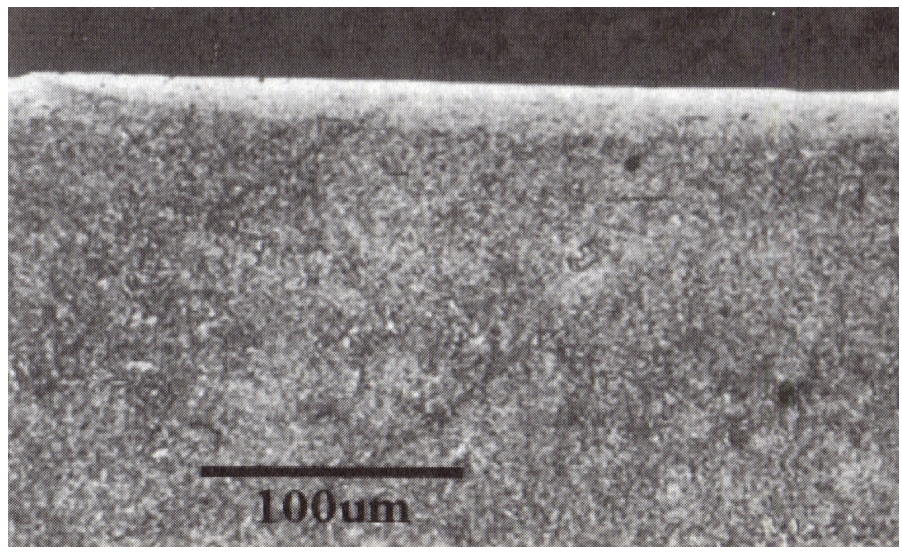

Figura 14. Seç̧ão mostrando uma camada branca produzida por torneamento em condição severa (Griffiths, 2001).

Em eventos unitários de processos mecanicamente dominados, a dureza aumenta constantemente do núcleo para a superfície, enquanto que em eventos unitários de processos termicamente dominantes este não é necessariamente o caso (Griffiths, 2001). A profundidade de endurecimento por tensão depende das condições da operação e do estado da ferramenta. Quanto mais severa é a condição maior será a profundidade endurecida.

Deformação plástica pode ocorrer como resultado de uma seqüência de processos, por exemplo: torneamento seguido de polimento. A seqüência dos processos é importante, pois afeta o estado final de tensão ou resistência. Os diferentes tratamentos térmicos e usinagens produzem diferentes incrementos na dureza como mostra a Figura 15, (Van Vlack, 1971).

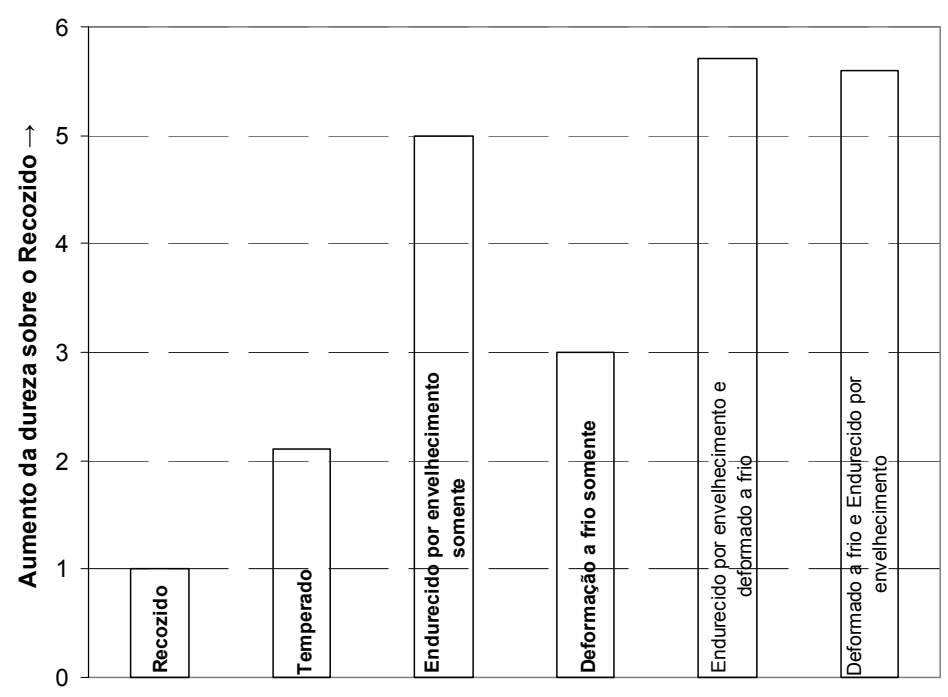

Figura 15. Aumento da dureza produzido por diferentes tratamentos (Van Vlack, 1971). 
Uma série de defeitos ou irregularidades nas superfícies pode ser associada a deformações plásticas:

\section{- Rebarbas}

Deformações plásticas geram rebarbas nas arestas usinadas de superfícies, que são consideradas como regiões propícias para início de trincas, portanto produzem uma Integridade Superficial de baixa qualidade. É hábito no chão de fábrica a remoção destas rebarbas devido à possibilidade da geração de trincas e riscos de acidentes.

Metcut (1980) apresenta exemplos de rebarbas e trincas associadas em furos de broca e alargadores e afirma que rebarbas produzem uma apreciável redução na resistência à fadiga.

Pavel et al (2005) analisou a influencia do desgaste de ferramenta na integridade superficial resultante no processo de torneamento em material endurecido. Relacionou (Figura 16 (a) e (b)) o aparecimento de maiores rebarbas na presença de desgaste de flanco (VB) na ferramenta.

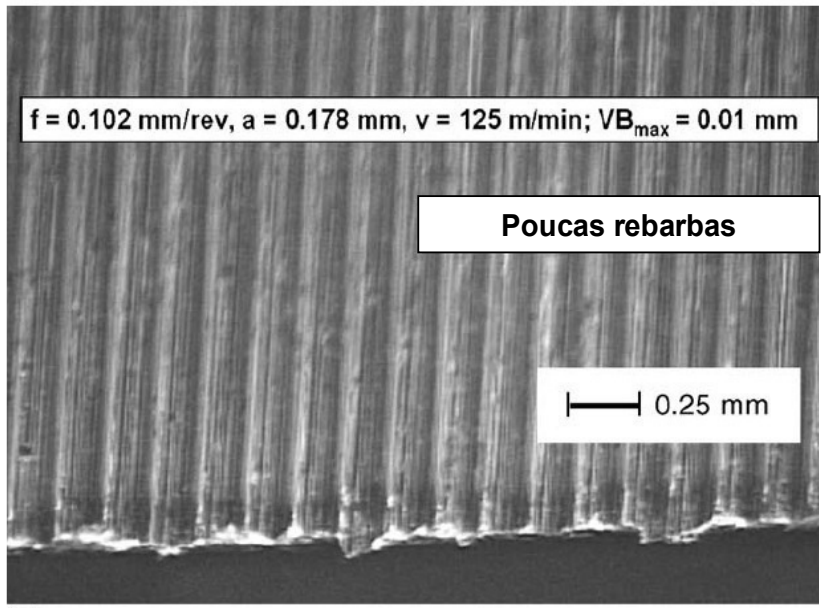

(a)

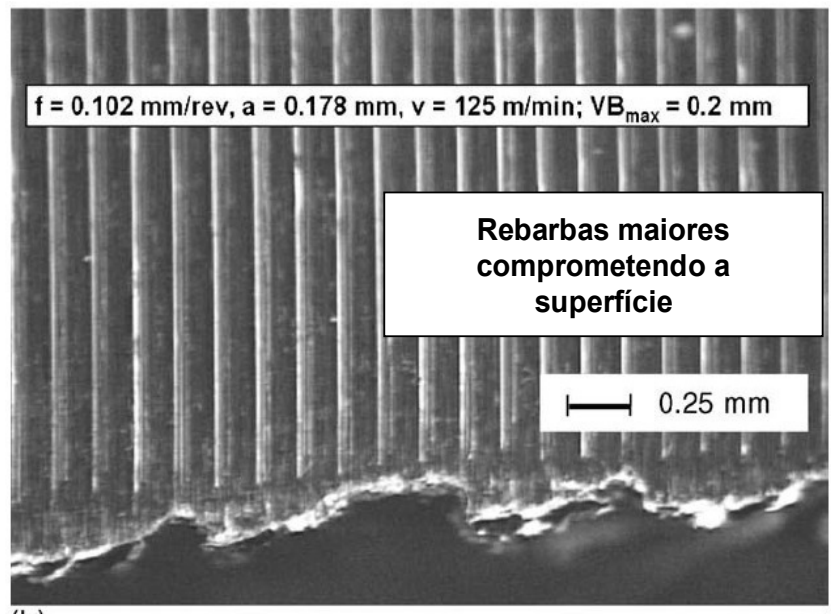

(b)

Figura 16. Formação de rebarbas sem a presença de desgaste (a) e na presença de desgaste de ferramenta (b) (Pavel et al, 2005).

\section{- Trincas}

Trincas estão diretamente associadas a Integridades Superficiais baixas e são causa de fadiga, corrosão, falhas de resistência e contato mecânico e quebras na superfície (Metcut, 1980).

Trincas preferenciais podem ocorrer ao longo de contornos de grãos enfraquecidos. A deformação plástica gera trincas e em condições severas as 
deformações podem sobrecarregar a superfície causando trincas. É o caso onde a superfície é polida por muito tempo. Em alguns casos extremos, uma sobrecarga gera a separação da superfície deixando vazios entre as subsuperfícies conforme mostra a Figura 17.

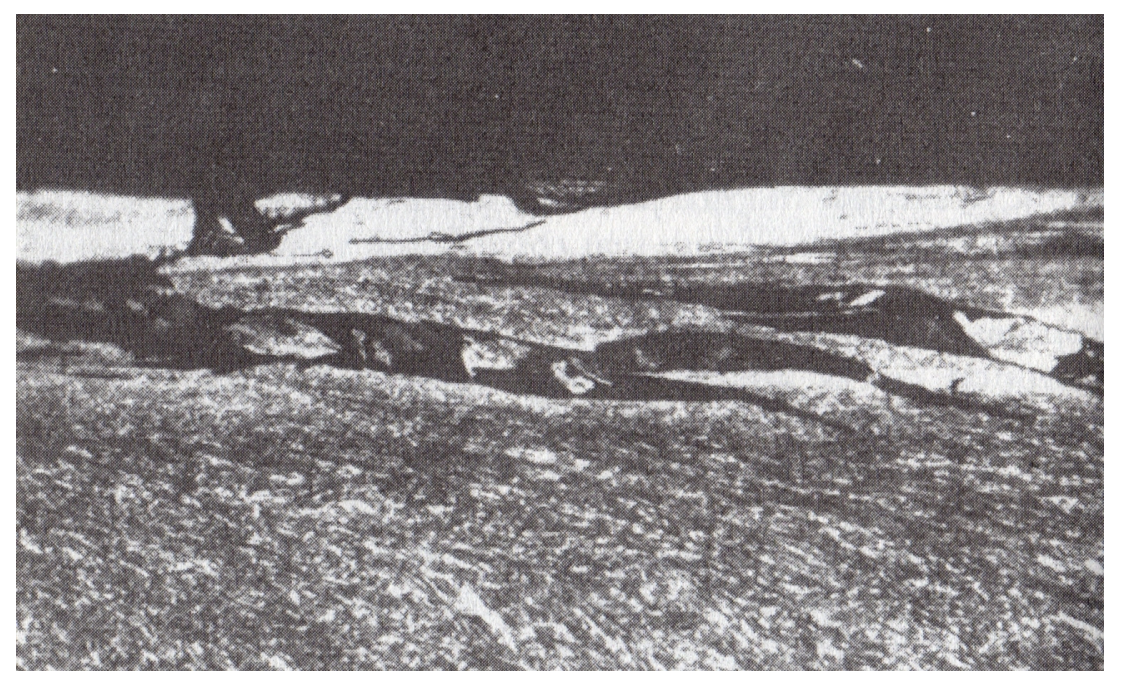

Figura 17. Trinca por deformação plástica em aço temperado e revenido (Metcut, 1980).

\subsubsection{Descontinuidades}

O acabamento em uma superfície usinada é geralmente diferente do teórico. Por exemplo, uma ferramenta de torneamento deveria, teoricamente, deixar sua forma exata na superfície usinada, esta é a base da teoria publicada por Metcut (1980).

Em processos de corte, o desvio do teórico com o real é muito dependente da velocidade de corte, devido aos efeitos térmicos que influenciam o evento primário de cisalhamento. Descontinuidades como aresta postiça, fraturas e riscos estão associados a baixas velocidades de corte e, por exemplo, fluxo lateral de material estando associado a altas velocidades de corte. Ambos os casos se aplicam a usinagem de material e são de interesse.

A Figura 18 apresenta uma condição de fluxo lateral de material associado a uma condição de aresta de ferramenta com desgaste, uma parte do material foi arrancado e outra parte foi comprimida (plungeada) contra a superfície devido a perda de capacidade de arranque da área desgastada. 


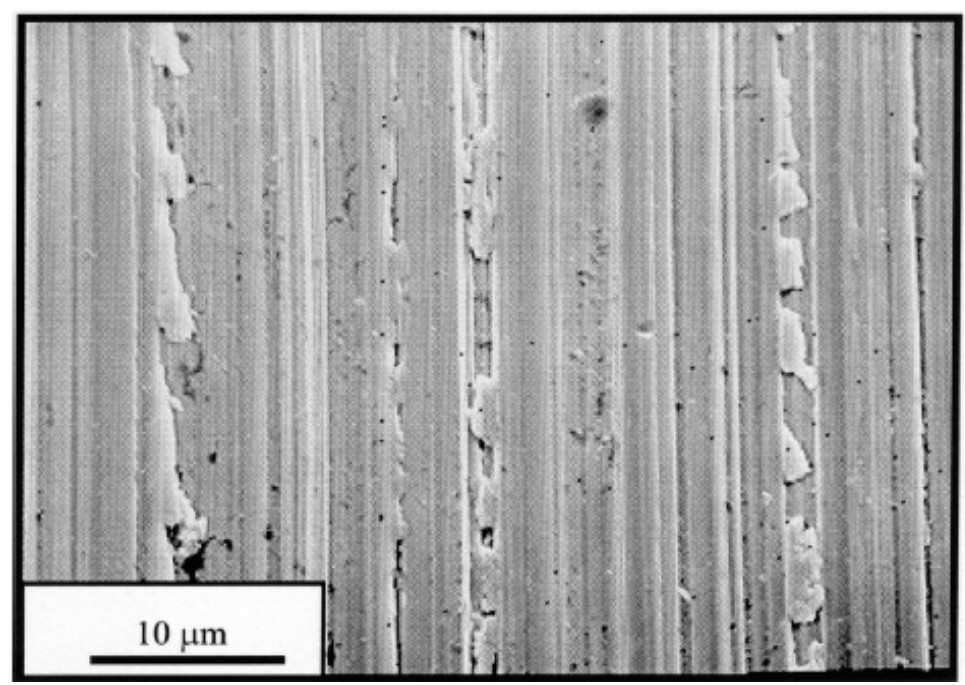

Figura 18. Fluxo lateral de material (Kishawy e Elbestawi, 1999).

\section{- Ressalto e riscos}

Em baixas velocidades de corte, o defeito mais comum é o acabamento grosseiro, causado pela presença de arestas postiças instáveis. Arestas postiças causam sérias implicações na integridade superficial e precisão dimensional. Os fragmentos ou escamas criados pelas arestas postiças são duros e frágeis e em situações de atrito agem como abrasivos. Depósito de arestas postiças na superfície é uma forma de ressalto adicionado na superfície. Um risco é o oposto, isto é, ocorre uma remoção de material da superfície. Riscos ocorrem porque em alguns casos a adesão entre a superfície e a ferramenta é tão alta que uma parte da superfície é arrancada fora. Isto causa uma depressão na superfície que distorce a topografia da superfície como mostra a Figura 19. A este fato dá-se o nome de arranque, que é um gerador de corrosão. No caso da Figura 19 o arranque aconteceu na camada branca adjacente à superfície em processo de retificação com condições severas.

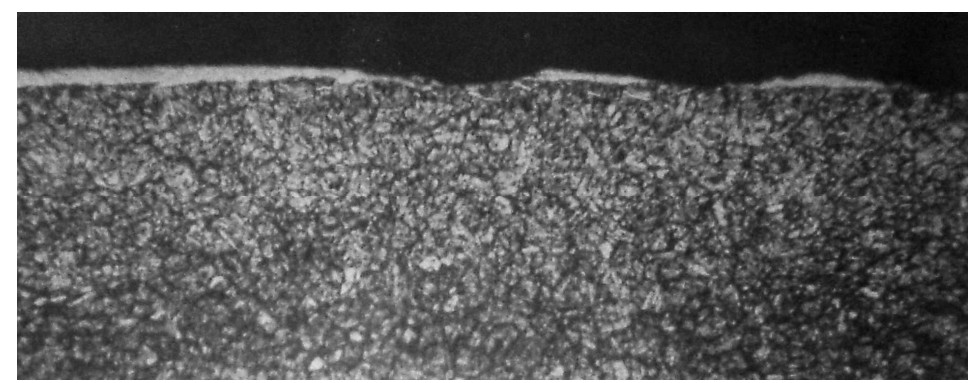

Figura 19. Arranque de material na camada branca superficial em processo de retificação em condição severa (Farias, 2007). 


\section{- Material redepositado ou refundido}

Em alguns processos de remoção de material nem todo o material é totalmente removido. No caso de eventos térmicos, uma parte do material é redepositada ou refundida de volta na superfície, causando uma camada adicional.

O material também pode ser redepositado em processos de usinagem convencional. Aresta postiça é uma forma de redeposito, causado pelo material altamente endurecido soldado na ponta da ferramenta que se desprende, sendo redepositado na superfície da peça.

Em retificação esta é maior causa de obtenção de superfícies com acabamento pobre. O material removido da superfície fica impregnado nos grãos do rebolo na primeira passada e na passada consecutiva este material se desprende e é redepositado na superfície por atrito. A Figura 20 mostra uma deposição de um grão de ferrita na superfície de uma peça de ferro fundido.

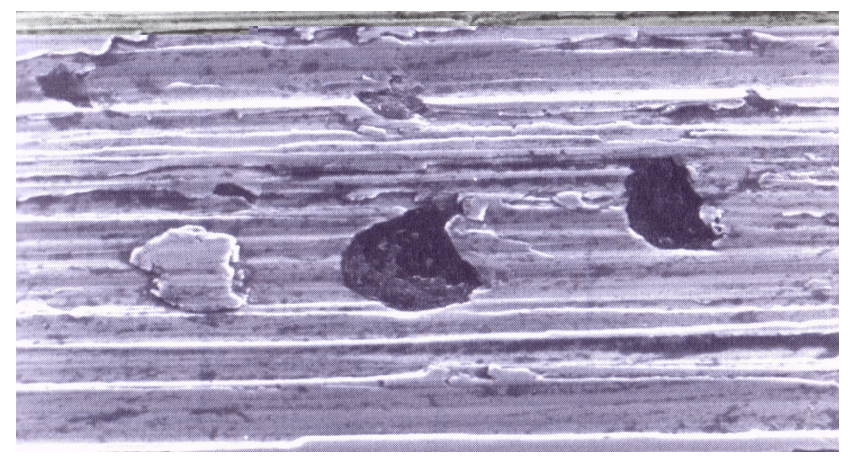

Figura 20. Grão de ferrita depositado em uma superfície de ferro fundido (Griffiths, 2001).

Durante a usinagem a ferramenta sofre um desgaste natural, as pequenas partículas do desgaste podem ser depositadas na superfície da peça ou na região inferior do cavaco. Tendo em mente a estabilidade de uma operação normal de usinagem e os muitos metros usinados durante a vida da ferramenta, estes depósitos serão poucos e estarão distantes entre si. No entanto existem exemplos de grãos de metal duro encontrados encravados na superfície de materiais, estes podem causar abrasão (Griffiths, 2001). 


\subsubsection{Camadas de Material Alterado e Evento Unitário de Usinagem}

Os mecanismos geradores do evento unitário podem ser basicamente divididos em três tipos: mecânico, térmico e químico, como descrito nos capítulos iniciais (Figura 3). Estes mecanismos estão sempre presentes, em maior ou menor grau, em todos os processos de usinagem e muitas vezes não existe uma clara distinção entre eles. Além disso, de grande importância são as condições de operações do processo; leve, convencional ou severa (Griffiths, 2001). Mesmo em condições de operação leve, em termos de velocidade de corte e avanço, a operação como um todo pode ser severa pelo fato da ferramenta estar desgastada. Poulachon et al (2001) apresentam a Figura 21 onde mostram o comportamento do desgaste da ferramenta em função do tempo na usinagem de um aço DIN 100 Cr6 endurecido. Pode-se observar três regiões distintas: desgaste inicial, desgaste controlado (plástico) e falha de ferramenta associadas às condições de operação do processo (leve, convencional ou severa).

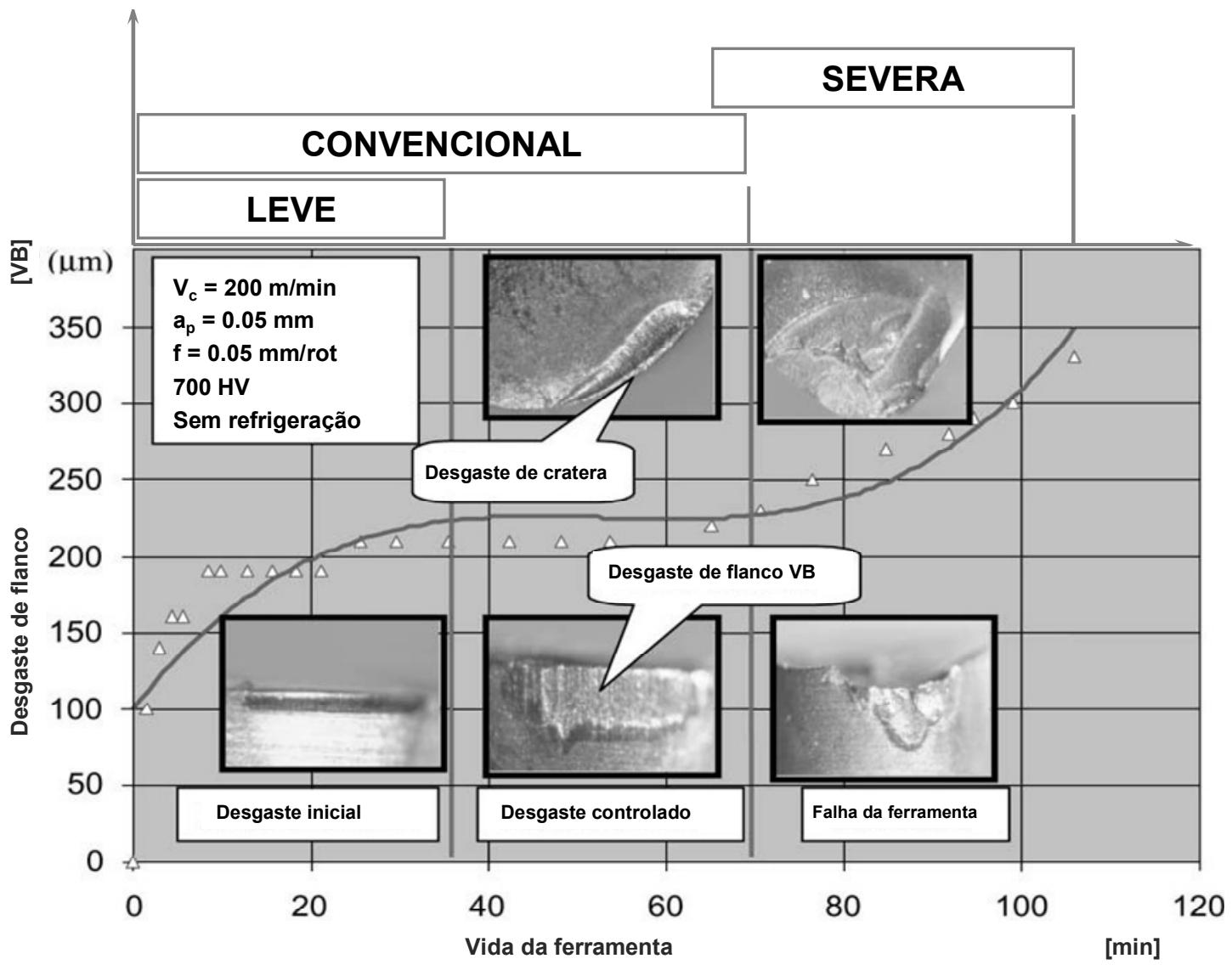

Figura 21. Desgaste da ferramenta com o tempo e a relação às condições de usinagem (Poulachon et al, 2001). 
O desgaste da ferramenta ou grão em função do tempo segue o formato clássico do " $\mathrm{S}$ " entre as três fases. Na primeira fase, inicialmente o desgaste é acentuado até que as condições se estabilizem. A seguir um regime de desgaste constante representa a maior parte da vida da ferramenta. $E$ por última fase o desgaste cresce gradualmente até a eventual falha. Normalmente a operação é interrompida antes da terceira fase, pois é nesta região que as condições se tornam realmente severas. As regiões leve, convencional e severas relacionam-se à IS e consecutivamente ao desempenho funcional. Razões pela qual a IS é reduzida na região severa são altas temperaturas e altas deformações plásticas.

\subsubsection{Camadas de Material Alterado e a Temperatura}

Todo o aumento na temperatura do evento unitário da usinagem provavelmente irá causar danos. Este será o caso com usinagem por corte utilizando ferramentas desgastadas na terceira ou última região da Figura 21. Não somente a temperatura gerada será alta, mas também o comprimento de contato para condução de calor entre ferramenta/grão e peça será maior.

Recentemente, Grzesik (2008) apresentou seus resultados do torneamento em um aço para rolamentos endurecido para $700 \mathrm{HV}$ correlacionando as temperaturas na interface cavaco, ferramenta e peça com presença de desgaste de flanco (VB). A Figura 22 apresenta os valores de temperatura máximos encontrados com a utilização de um pirômetro.

Vários experimentos com desgaste foram simulados, produzindo-se artificialmente zonas desgastadas nas faces de folga de ferramentas de torneamento. Boothroyd et al apud Griffiths, 2001, mostram que o fluxo de calor para a peça com uma de uma ferramenta com zona desgastada de $0,5 \mathrm{~mm}$ é mais do que o triplo quando comparado à uma ferramenta nova. Bailey et al apud Griffiths, 2001, mostrou que a profundidade da camada afetada triplicou com o uso de uma ferramenta com área desgastada de $0,5 \mathrm{~mm}$, em comparação a uma ferramenta nova. Estes dois resultados podem ser vistos no gráfico da Figura 23. 


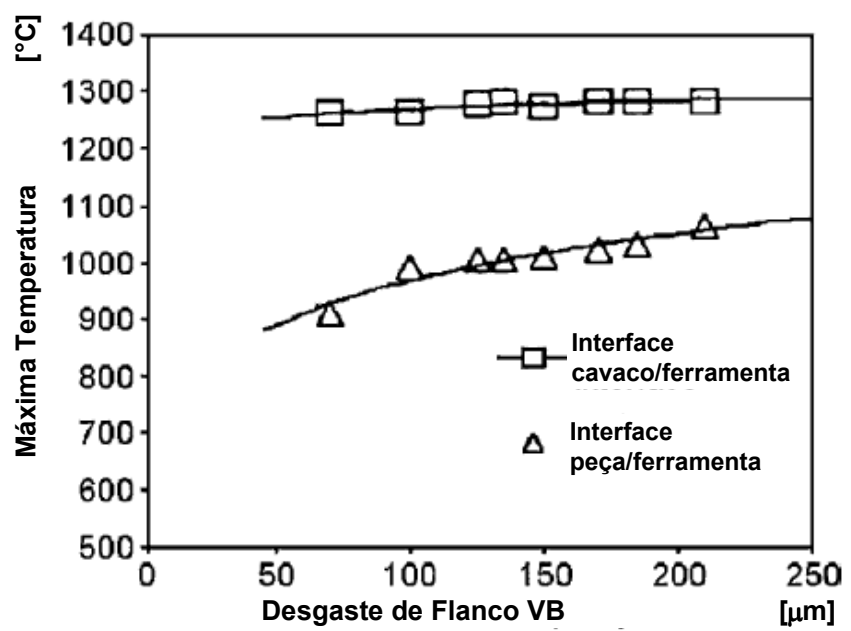

Figura 22. A influência do desgaste em ferramenta de torno sobre o fluxo de calor nas interfaces cavaco/ferramenta e peça/ferramenta (Grzesik, 2008).

$\mathrm{Na}$ Figura 23 pode-se verificar o aumento da temperatura na interface peça/ferramenta em função do desgaste de flanco VB.

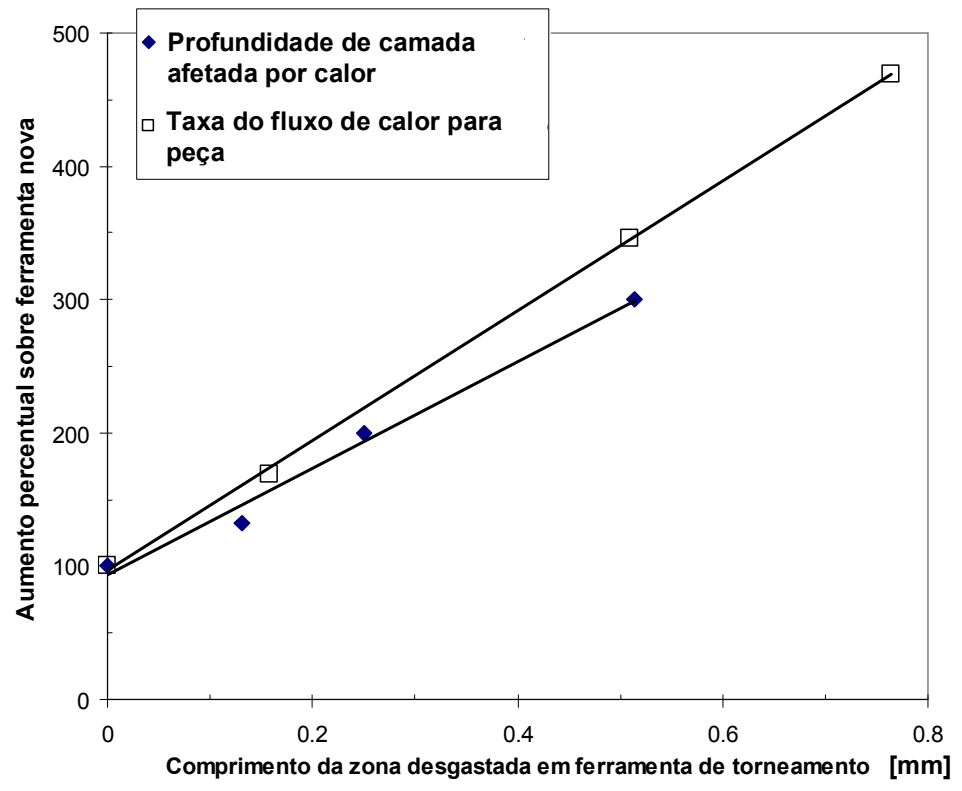

Figura 23. A influência da zona desgastada em ferramenta de torno sobre o fluxo de calor e a profundidade de deformação plástica (Griffiths, 2001).

\subsubsection{Camadas de Material Alterado e os Processos de Manufatura}

A Tabela 2 relaciona classes de processos com características subsuperficiais. A presença da característica é dependente da condição de operação usada, "L" para condição leve e "S" para condição severa. 
Tabela 2. Relação entre classes de processos, características subsuperficiais e condições de operação (Griffiths, 2001).

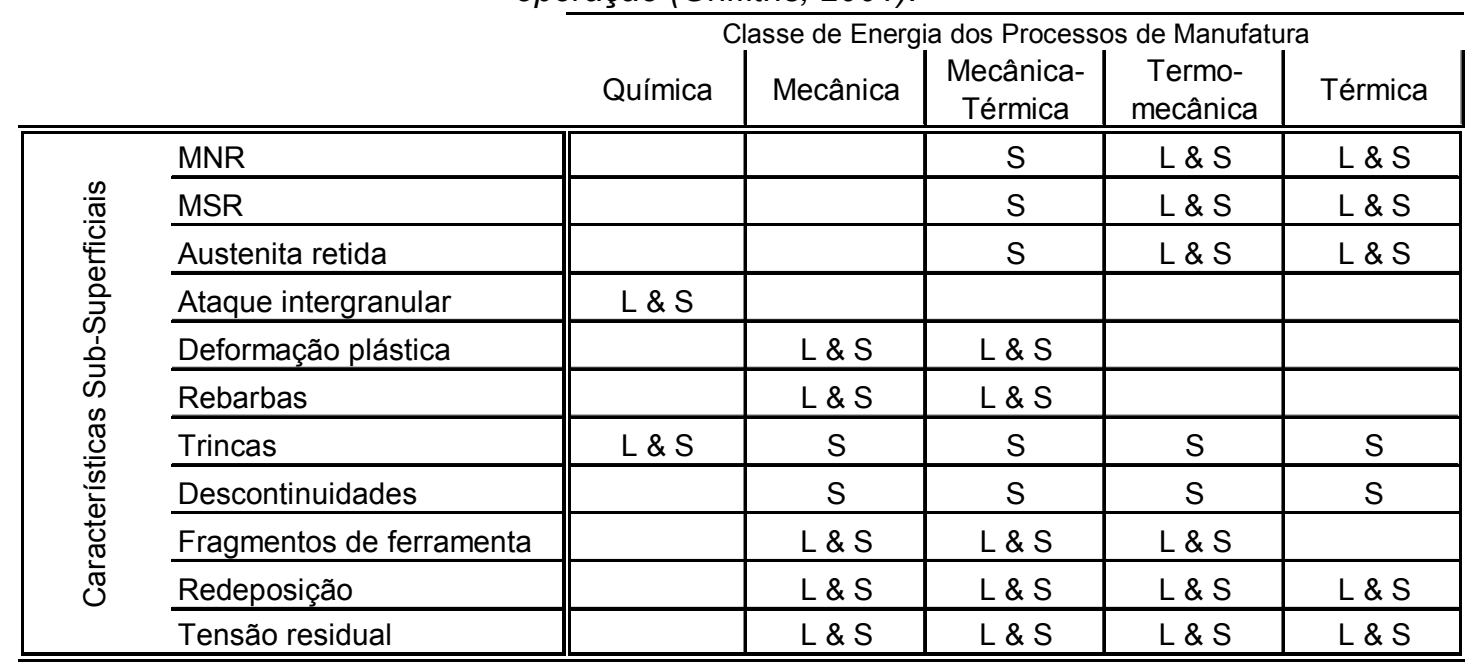

L: Leve S: Severa

\subsubsection{A influência da Camada de material Alterado no Desempenho Funcional}

A Tabela 3, proposta por Griffiths (2001), mostra que as características superficiais e subsuperficiais exercem uma influência na desempenho em várias situações de serviço. Um engenheiro, ao selecionar um processo de usinagem, deve incluir integridade superficial como sendo um critério de seleção.

Tabela 3. Influência das características subsuperficiais nas situações funcionais (Griffiths, 2001).

\begin{tabular}{|c|c|c|c|c|c|c|c|c|c|c|c|c|}
\hline & \multicolumn{12}{|c|}{ Integridade Superficial e Características Sub-Superficiais } \\
\hline & \multicolumn{4}{|c|}{ Metalúrgico } & \multicolumn{5}{|c|}{ Deformação } & \multicolumn{2}{|c|}{ Depósitos } & \multirow{2}{*}{$\begin{array}{c}\text { Tensão } \\
\text { Tensão } \\
\text { Residual }\end{array}$} \\
\hline & $\begin{array}{c}\text { MNR ou } \\
\text { CB }\end{array}$ & MSR & $\begin{array}{c}\text { Austenitiza- } \\
\text { ção }\end{array}$ & $\begin{array}{c}\text { Ataque } \\
\text { intergranular }\end{array}$ & $\mathrm{CB}$ & $\begin{array}{c}\text { Deformação } \\
\text { Plástica }\end{array}$ & Rebarbas & Trincas & $\begin{array}{l}\text { Ressaltos } \\
\text { \& Riscos }\end{array}$ & $\begin{array}{c}\text { Fragmentos } \\
\text { de } \\
\text { Ferramentas }\end{array}$ & Redeposição & \\
\hline Desgaste & $\bullet$ & & O & O & $\bullet$ & $\boldsymbol{0}$ & $\bullet$ & $\bullet$ & ○ & $\boldsymbol{0}$ & $\bullet$ & 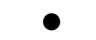 \\
\hline Resistência & $\bullet$ & $\bullet$ & $\bullet$ & $\bullet$ & $\bullet$ & $\bullet$ & $\bullet$ & $\bullet$ & $\bullet$ & O & O & $\bullet$ \\
\hline \begin{tabular}{|l} 
Ataque \\
Químico
\end{tabular} & $\theta$ & & & $\bullet$ & $\bullet$ & ○ & & $\bullet$ & $\bullet$ & 0 & & 0 \\
\hline Fadiga & $\bullet$ & $\bullet$ & 0 & $\bullet$ & $\bullet$ & $\bullet$ & $\bullet$ & $\bullet$ & $\bullet$ & & 0 & $\bullet$ \\
\hline Magnetismo & & & & & 0 & 0 & & & & & & \\
\hline \begin{tabular}{|l|} 
Capacidade \\
de carga
\end{tabular} & $\bullet$ & & & 0 & 0 & 0 & $\bullet$ & $\bullet$ & $\bullet$ & 0 & $\theta$ & \\
\hline Vedação & 0 & & & 0 & 0 & 0 & $\bullet$ & $\bullet$ & 0 & 0 & $\theta$ & \\
\hline Atrito & $\theta$ & & & & & & $\bullet$ & $\bullet$ & 0 & 0 & 0 & \\
\hline Adesão & 0 & & & 0 & & & 0 & - & 0 & 0 & 0 & - \\
\hline Conformação & • & & & & • & • & - & - & • & • & 0 & • \\
\hline
\end{tabular}


A Tabela 3 não indica se o efeito da característica é bom ou ruim para o desempenho. Em alguns casos a CMA influencia positivamente e em outros casos negativamente Griffiths (2001). Por exemplo, em situações de desgaste, camadas de MNR e camadas redepositadas aumentam o desgaste, pois estão endurecidas, frágeis, instáveis, contendo tensão residual de tração e são susceptíveis ao lascamento. Por outro lado tensão residual de compressão é benéfica para aumentar a resistência à fadiga de componentes mecânicos. 


\subsection{Tratamento Termoquímico de Cementação}

Carbonetação ou Cementação (termo mais difundido tecnicamente no Brasil) é a adição de carbono à superfície de aços de baixo carbono em temperaturas geralmente entre 850 e $950^{\circ} \mathrm{C}$. A esta temperatura a austenita está estável em uma estrutura cristalina com alta solubilidade em carbono (Lampman, 1991). Este processo visa melhorar a temperabilidade na superfície do material, mantendo no núcleo suas características originais.

\subsubsection{Processos de Cementação}

A cementação é um processo de difusão do carbono em uma camada superficial do aço para produzir peças com elevada resistência ao desgaste após um tratamento térmico de endurecimento. Qualquer operação de saturação de uma superfície por difusão deve ser executada em meio externo que possa liberar o elemento a ser difundido em um estado atômico (iônico). Deve haver o contato dos átomos que serão difundidos com a superfície a ser tratada e a formação de ligações químicas com os átomos da matriz metálica (absorção) e deve haver a difusão propriamente dita que é penetração do soluto na matriz metálica (Baumgarten, 2003)

O processo de cementação do aço é uma função do tempo e dos recursos disponíveis (potencial de carbono) na superfície. Quando o tempo é prolongado, são obtidas grandes profundidades de penetração e um elevado potencial de carbono produz uma superfície com grande conteúdo de carbono, podendo resultar em excessiva quantidade de austenita retida ou grande quantidade de carbonetos livres. Estes dois elementos microestruturais causam efeitos adversos sobre a distribuição da tensão residual na peça cementada (Faria e Munhoz, 1990). Por conseguinte, um elevado potencial de carbono pode ser adequado para curto ciclo de tratamento, mas não para ciclos prolongados. 
A principal finalidade da cementação é obter uma camada mais dura e resistente ao desgaste na superfície da peça, portanto o processo de cementação sempre é acompanhado de um posterior processo de tempera e revenimento que visa auferir a superfície da peça uma dureza específica previamente selecionada.

Baumgarten, 2003, descreve a estrutura da camada cementada, para uma condição de resfriamento lento com ajuda do diagrama de equilíbrio $\mathrm{Fe}-\mathrm{C}$, conforme Figura 24.

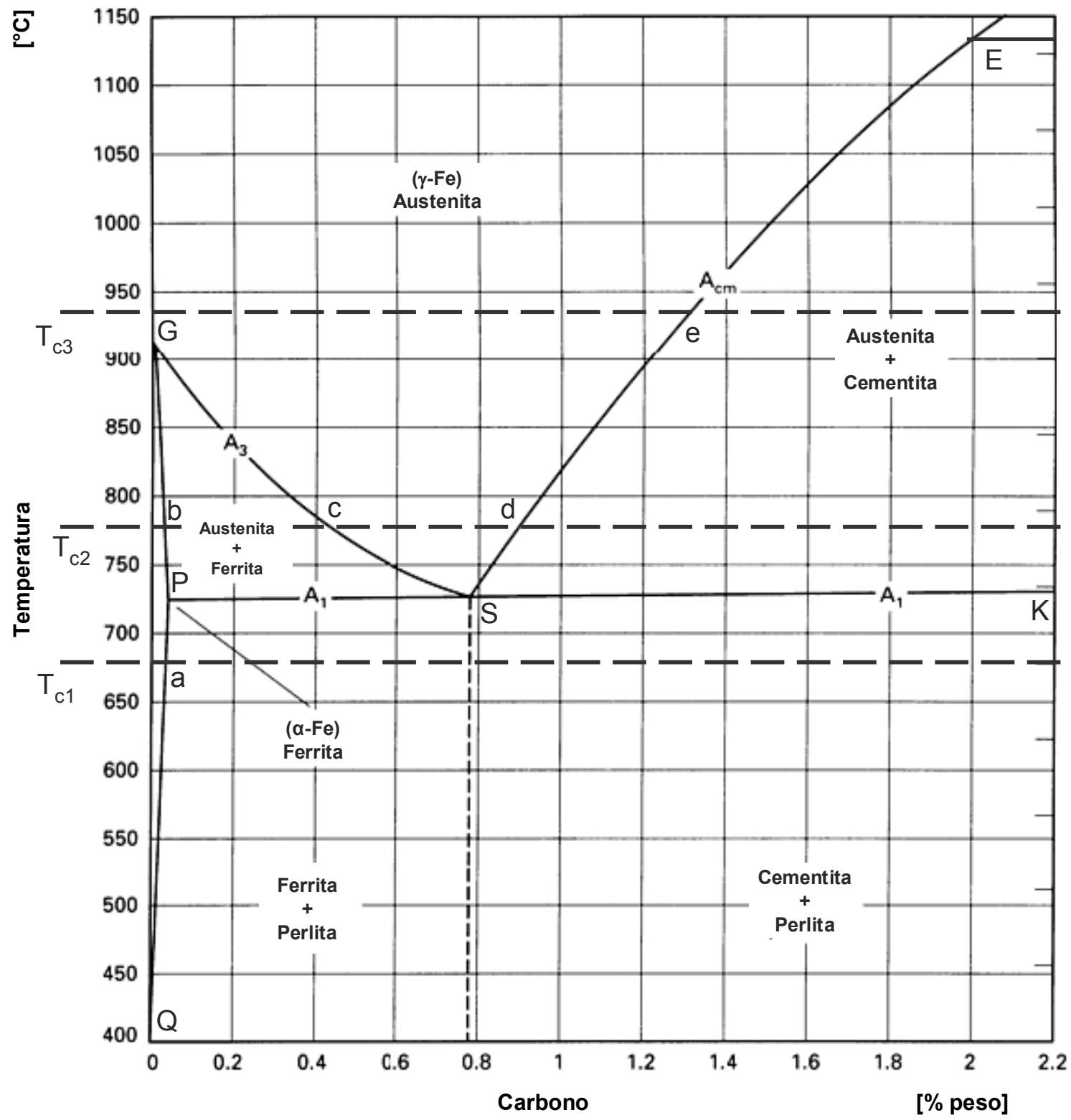

Figura 24. Diagrama de equilíbrio Fe-C (ASM Handbook, 1991). 
Se a carbonetação ocorre a uma temperatura $T_{c 1}$, abaixo da temperatura eutetóide (linha $A_{1}$ ), então uma solução sólida do carbono no ferro a é formada primeiro. Quando a solução sólida é saturada com carbono, como determinado pela linha PQ no diagrama de equilíbrio (ponto "a") a cementita começa a se formar na superfície. Então, neste caso, obtém-se uma camada de cementita na superfície do aço, na zona de difusão. Inicialmente o carbono se difunde no ferro- $\alpha$ à temperatura $T_{c 2}$, entre os pontos críticos $A_{1}$ e $A_{3}$. Quando a saturação máxima for alcançada (ponto b) uma solução sólida de carbono no ferro- $\gamma$ (austenita) é formada. Quando a máxima saturação da austenita for atingida, determinado pela linha SE do diagrama (ponto d), a próxima fase estável nesta temperatura será formada, esta fase é a cementita. Um resfriamento lento a partir da temperatura de cementação causará a decomposição da austenita com a precipitação ou de cementita ou de ferrita, dependendo da composição. No ponto crítico $A_{1}$, a perlita é formada pela transformação eutetóide. $O$ excesso de cementita é precipitado durante o resfriamento da solução sólida $\alpha$ existente na temperatura de cementação. Finalmente, na temperatura de cementação $T_{c 3}$, acima do ponto crítico $A_{3}$, o carbono se difundirá no ferro- $\gamma$. Quando a saturação máxima (ponto e) é alcançada, a camada de cementita será formada. A austenita se decomporá de acordo com o diagrama de equilíbrio a partir da temperatura de cementação.

$\mathrm{Na}$ prática, o aço é cementado em uma faixa de 850 a $950^{\circ} \mathrm{C}$, na qual o carbono é difundido em ferro- $\gamma$. As discussões acima sobre a formação da camada cementada referem-se a casos extremos. Em condições reais a formação de camadas de cementita raramente é observada. Para se obter uma camada contínua de cementita na zona de difusão, o aço deve ser cementado por um tempo longo em um meio carbonetante ativo contendo uma quantidade considerável de carbono.

A camada cementada tem uma concentração variável de carbono ao longo da profundidade, decrescendo a partir da superfície em direção ao núcleo com a consequente mudança gradual na composição química da camada, conforme podemos verificar na Figura 25 que apresenta a concentração de carbono na superfície do aço ABNT 8620 cementado. 


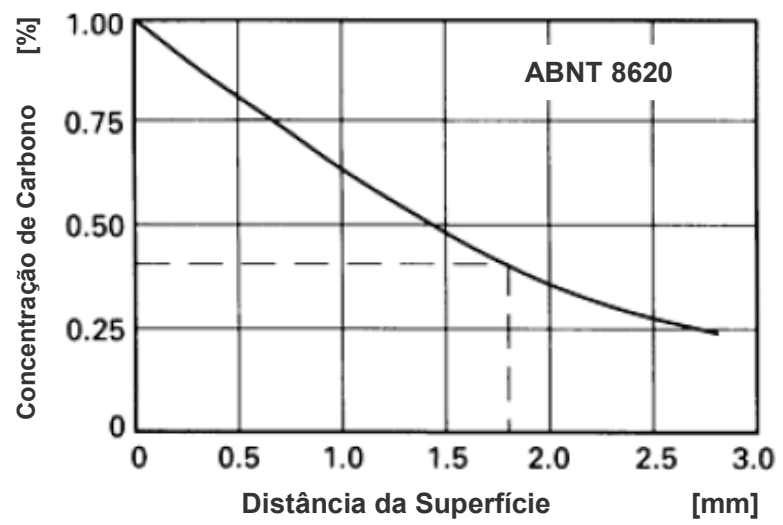

Figura 25. Concentração de carbono na superfície para o aço ABNT 8620 (ASM Handbook, 1991).

A profundidade da camada cementada na superfície depende da temperatura do processo, do tempo de processo e da atividade do meio carbonetante que fornece átomos de carbono para a camada cementada, a Figura 26 apresenta o efeito do tempo e temperatura na profundidade da camada cementada (Harris, 1944 apud ASM Handbook, 1991).

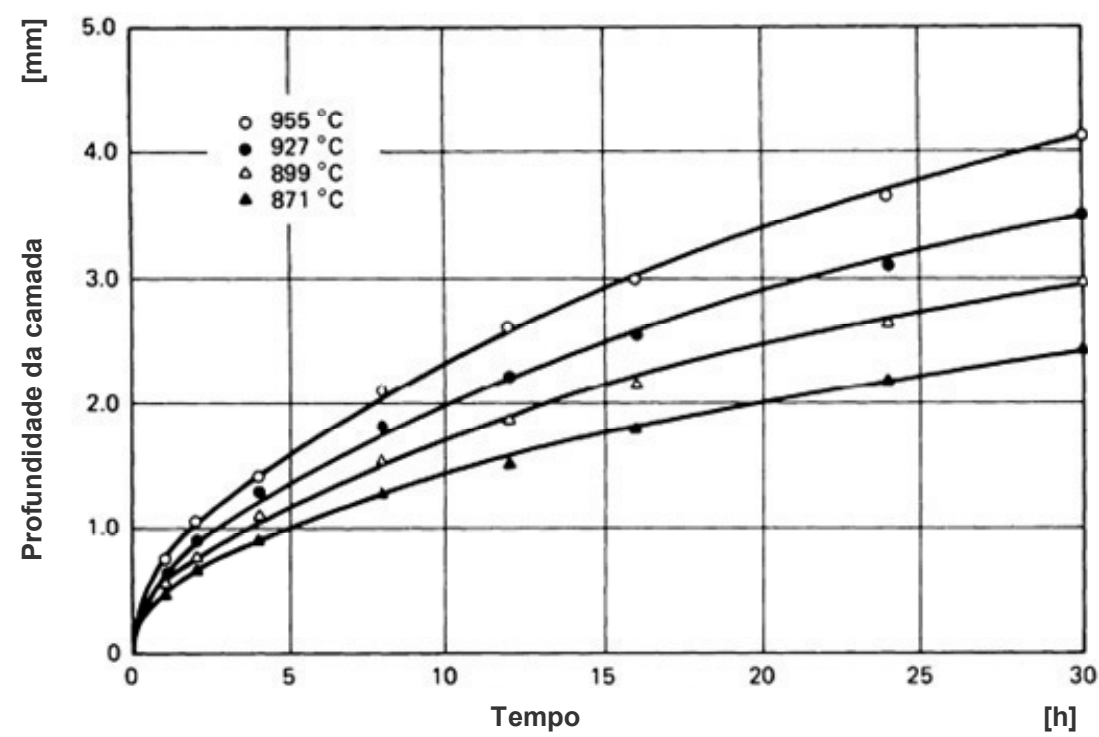

Figura 26. Efeito do tempo e temperatura na profundidade da camada cementada (Harris, 1944 apud ASM Handbook, 1991).

A Figura 27 apresenta relação de tempo e temperatura na cementação do aço ABNT 8620 para uma mesma camada efetiva de $1,5 \mathrm{~mm}$. O correto teor de carbono na superfície deve ser entre 0,8 e 1,0\%. Altas concentrações de carbono levarão a formação de carbonetos em rede (cementita). Esta rede dificilmente será eliminada com tratamentos térmicos subsequentes e irá deteriorar a qualidade da camada. 


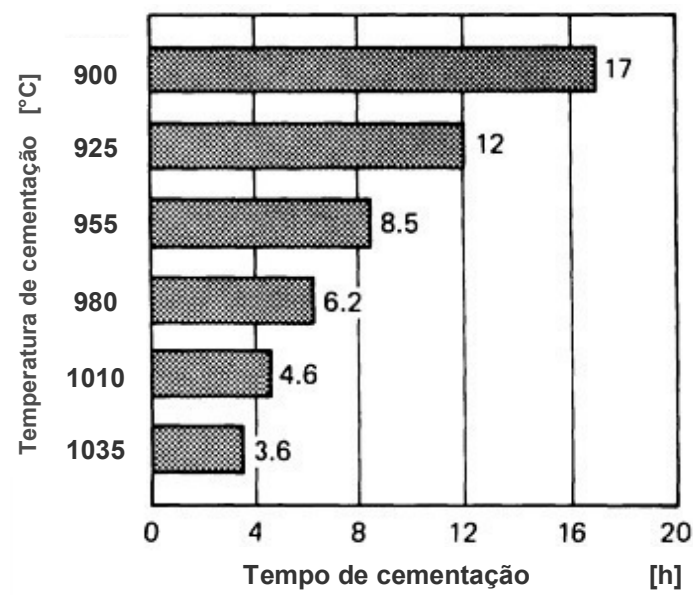

Figura 27. Relação entre tempo e temperatura na cementação do aço ABNT 8620 para uma mesma camada efetiva de 1,5mm (Shultz et al, 1989 apud ASM Handbook, 1991).

A cementação cria uma camada com dureza superficial de até $800 \mathrm{HV}$ como pode ser notado na Figura 28 que apresenta o perfil de dureza de uma barra de diâmetro $16 \mathrm{~mm}$ em aço ABNT 8620 cementada em processo gasoso na temperatura de $925^{\circ} \mathrm{C}$.

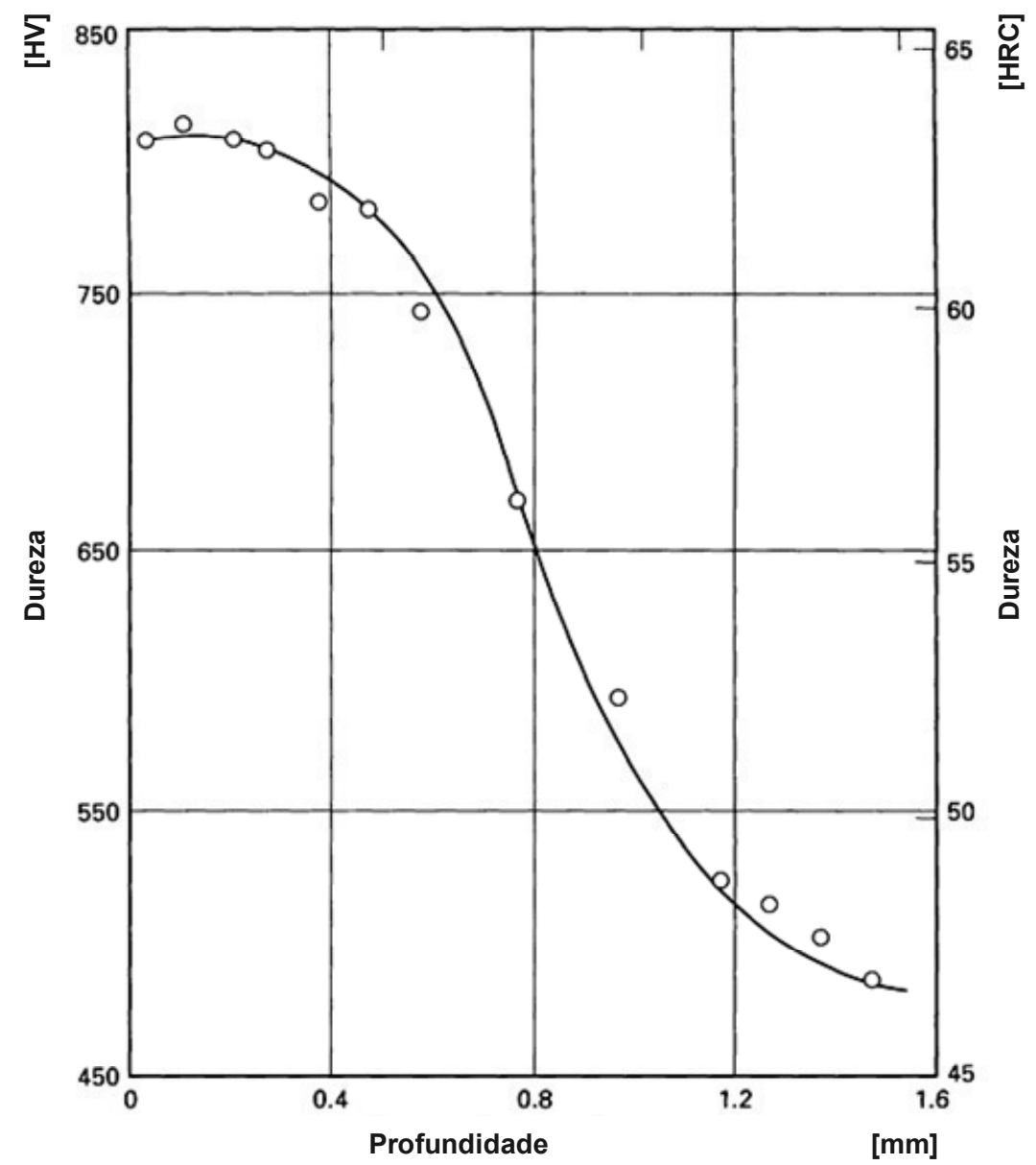

Figura 28. Distribuição esquematizada da profundidade da concentração de carbono e da dureza em uma peça cementada (Macherauch, 1992). 
De acordo com Rech e Moisan, (2003) a cementação também modifica o perfil de tensão residual da superfície e tensões de compressão são introduzidas, como mostra a Figura 29.

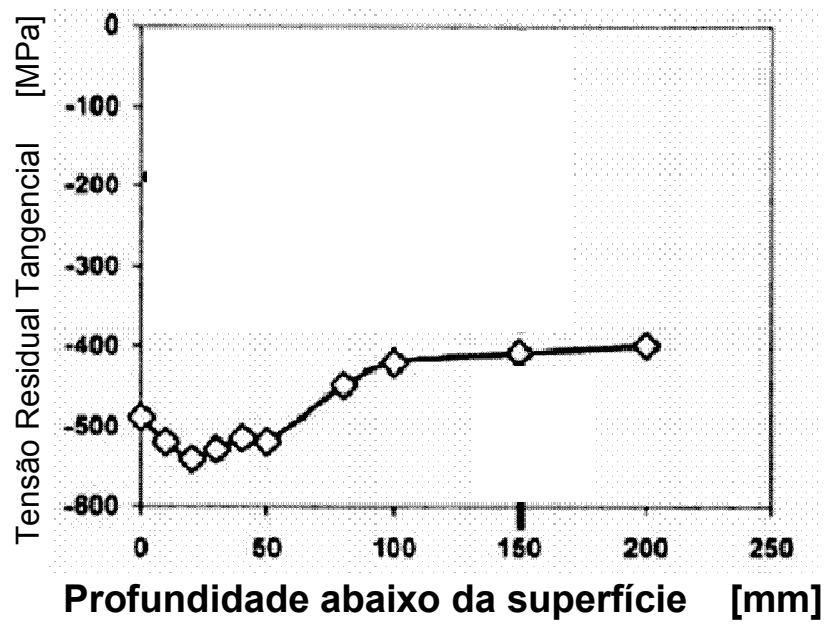

Figura 29. Perfil de tensão residual de superfície após processo de cementação (adaptado de Rech e Moisan, 2003).

\subsubsection{Aços para Cementação}

O primeiro requisito é baixo teor de carbono, porque a difusão do carbono será mais rápida e principalmente porque, com isso, o núcleo de baixo carbono apresentará tenacidade e resistência ao choque das peças. Contudo, em algumas aplicações, prefere-se um núcleo de resistência mais elevada, correspondente à estrutura martensita revenida, a qual pode ser obtida com carbono mais elevado (em torno de $0,30 \%$ ) e principalmente com os elementos de liga níquel (até $3,75 \%$ ), cromo (até 1,75\%) e molibdênio (até 0,60\%) (Lampman, 1991).

O aço ABNT 8620 é um aço muito utilizado para cementação. Após o tratamento térmico de cementação o teor de carbono na região superficial da peça é aumentado para aproximadamente $1.0 \%$ e sua tensão de escoamento na condição endurecida pode chegar a $860 \mathrm{MPa}$, enquanto que em seu núcleo a tensão de escoamento é de 385 MPa (Ogata, 2003). Já no Metals Handbook (1998), encontra-se referências que indicam que a tensão de escoamento na condição temperada e revenida pode chegar a $965 \mathrm{MPa}$. 


\subsubsection{Cementação Líquida}

No processo de cementação líquida as peças são mantidas a uma temperatura acima da linha $A_{1}$ do diagrama Fe-C (Figura 24 , por volta de $850^{\circ} \mathrm{C}$ ) em um banho de sal fundido (cianeto) que irá difundir carbono na superfície da peça metálica. A difusão do carbono a partir da superfície em direção ao núcleo produz uma camada que pode ser endurecida, normalmente por resfriamento rápido em banho de óleo. O carbono difunde-se a partir do banho para o metal e produz uma camada comparável com a resultante da cementação a gás. No entanto, o fato da cementação líquida envolver uma maior troca de calor efetiva (devido às características das soluções em banho de sal resultarem em uma taxa de transferência de calor superior), os tempos de ciclo na cementação líquida são mais curtos do que os da cementação a gás (Godding, 1991).

A maioria dos líquidos utilizados nos banhos de cementação líquida contém cianeto, que introduz tanto carbono quanto nitrogênio para a camada. Um tipo de particular de banho líquido, porém, usa somente uma fonte de carbono. Este banho produz um processo que contém apenas carbono como o agente de difusão. Camadas produzidas por cementação líquida podem atingir profundidades de até 6,35 mm (Godding, 1991).

A reação química envolvida não é totalmente compreendida, mas envolve a adsorção de monóxido de carbono, em partículas de carbono. O monóxido de carbono é gerado pela reação entre o carbono e carbonatos, que são os constituintes do banho de sal fundido. O monóxido de carbono adsorvido é reage com as superfícies do aço como na cementação gasosa.

Segundo Baumgarten, 2003, atualmente a cementação líquida, em banho de cianeto, representa $65 \%$ dos processos utilizados no mundo, sendo que no Brasil o emprego do cianeto representa aproximadamente $85 \%$ dos processos comerciais.

Não há diferença no princípio de cementação entre a cementação por via sólida e o processo por via gasosa (Ogata, 2003). 


\subsubsection{Cementação Gasosa}

A cementação gasosa possui vantagens sobre os outros métodos, pois existe a possibilidade de se obter um melhor controle de processo e de obtenção de uma profundidade de camada mais precisa. É um processo mais seguro, limpo e menos nocivo ao meio ambiente, quando comparado com os meios carbonetantes sólidos à base de carbono ativados com cloretos e carbonatos e com os meios líquidos, normalmente, à base de cianetos (Ogata, 2003).

Um processo de cementação gasosa depende, sobretudo, do controle efetivo das três principais variáveis do processo: composição da atmosfera, tempo, temperatura. Os gases comumente utilizados como gás de proteção e carbonetantes são: o metano $\left(\mathrm{CH}_{4}\right)$, propano $\left(\mathrm{C}_{3} \mathrm{H}_{3}\right)$ e butano $\left(\mathrm{C}_{4} \mathrm{H}_{10}\right)$.

As reações dos hidrocarbonetos dentro da câmara do forno aumentam o potencial de carbono, além do carbono disponível para a cementação, pela redução do ponto de orvalho $\left(\% \mathrm{H}_{2} \mathrm{O}\right)$ e do teor de $\mathrm{CO}_{2}$. O potencial de carbono da atmosfera pode ser rapidamente reduzido dentro da câmara de cementação pela injeção de pequenas quantidades de ar, com o objetivo de aumentar o ponto de orvalho e o teor de dióxido de carbono. A Figura 30 apresenta a relação entre o ponto de orvalho e o potencial de carbono difundido no ferro para dois tipos de gás constituintes da atmosfera.

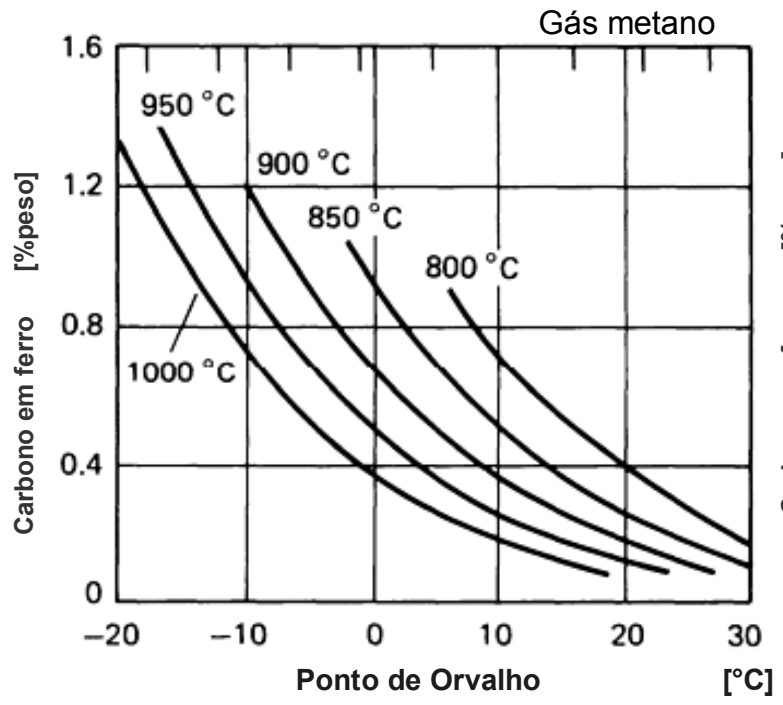

(a)

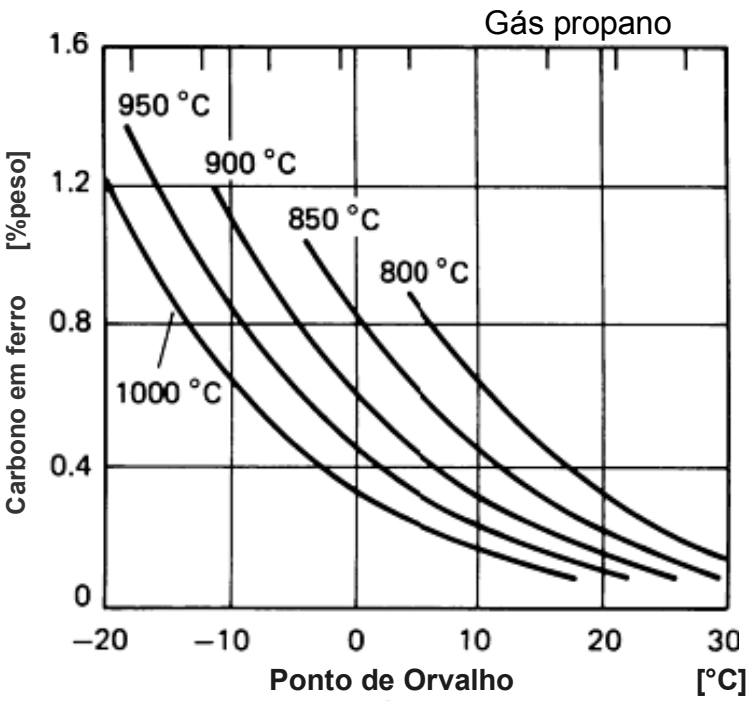

(b)

Figura 30. Relação entre ponto de orvalho e potencial de carbono para (a) gás metano e (b) gás propano (ASM Handbook, 1991). 
A cementação gasosa é um processo nonequilibrium (Stickels, 1991), isto é, os gases constituintes da atmosfera não estão em equilíbrio, a atmosfera não está em equilíbrio com o aço sendo cementado. No entanto, várias abordagens de controle do equilíbrio permitem previsões da taxa de cementação, a partir da composição da atmosfera do forno. Assim, o mesmo gradiente de carbono difundido na camada pode ser esperado, como mostra a Figura 31, a partir de diferentes fornos com atmosferas de gases diferentes, quando determinados fatores são mantidos constantes:

-Potencial de carbono, a partir de $\mathrm{CO}_{2}$ (Figura 31) e $\mathrm{H}_{2} \mathrm{O}$ (Figura 30) ou medições do potencial de oxigênio;

-Tempo da cementação;

-Temperatura do processo.

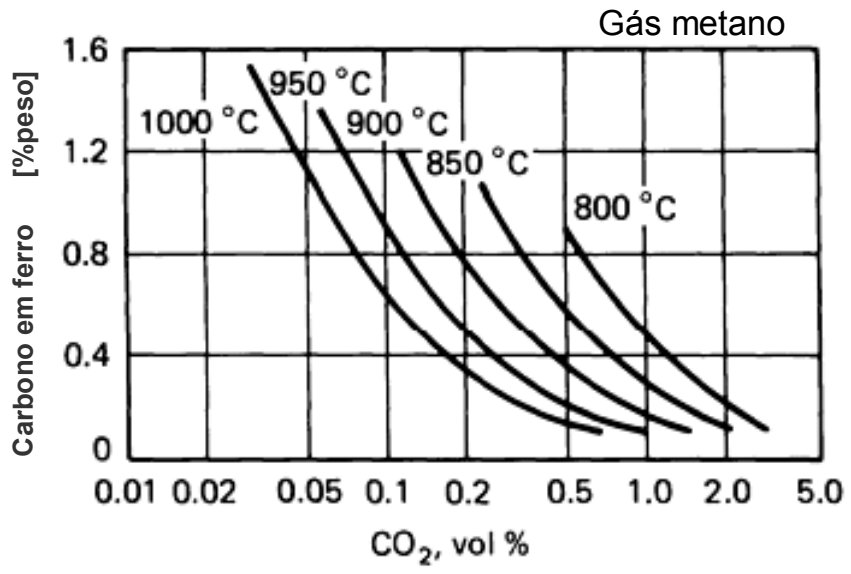

(a)

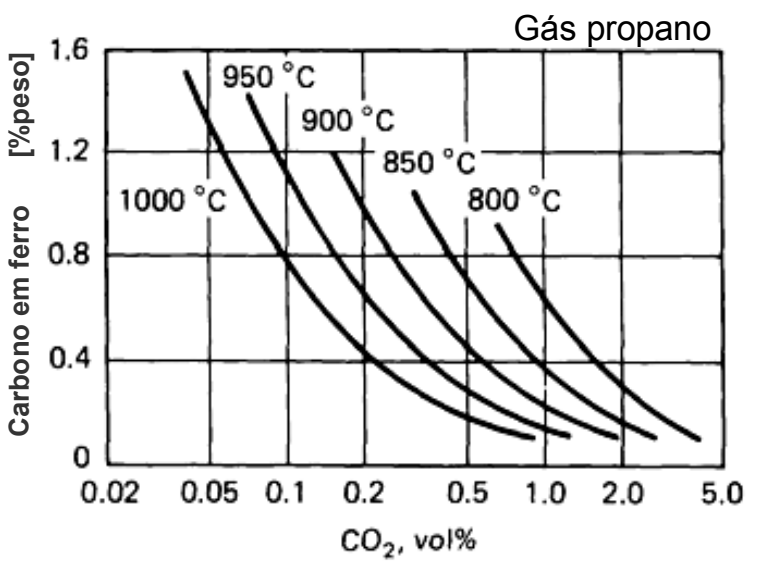

(b)

Figura 31. Relação entre $\mathrm{CO}_{2}$ e potencial de carbono para (a) gás metano e (b) gás propano (ASM Handbook, 1991).

\subsubsection{Difusão do Carbono}

O processo de cementação é controlado pela difusão do carbono através da superfície do material, sendo este muito influenciado pela temperatura, potencial de carbono do meio carbonetante e tempo de processo. A cinética de cementação pode ser expressa através das Equações de Fick que definem o cálculo do Coeficiente de 
Difusão (Equação 1) e a sua derivada de segunda ordem conhecida como Segunda Lei de Fick que mostra o perfil de concentração de carbono em função da distância, para um dado tempo de cementação (Equação 2) (Baumgarten, 2003)

$$
\begin{aligned}
& D=D_{0} e^{\left(-Q \frac{Q}{R T}\right)} \\
& \frac{d c}{d t}=D \frac{d^{2} c}{d x^{2}}
\end{aligned}
$$

Onde: $\quad D=$ coeficiente de difusão $\left[\mathrm{m}^{2} / \mathrm{s}\right]$

$\mathrm{D}_{0}=$ constante de difusividade $\left[\mathrm{m}^{2} / \mathrm{s}\right]$

$Q=$ energia de ativação para difusão [J/mol]

$\mathrm{R}=$ constante dos gases perfeitos $[\mathrm{J} /(\mathrm{mol} . \mathrm{K})]$

$\mathrm{T}_{\mathrm{a}}=$ temperatura absoluta $[\mathrm{K}]$

A solução analítica da $2^{a}$ Lei de Fick para um sólido finito, aplicado ao processo de cementação pode ser escrito conforme as Equações 3 e 4.

$$
C(x)=\left[1-\operatorname{erf}\left(\frac{1}{2} \frac{x}{\sqrt{D t}}\right)\right]\left(C_{s}-C_{0}\right)+C_{0}=C_{x}
$$

ou

$$
\frac{C_{x}-C_{0}}{C_{s}-C_{0}}=1-\operatorname{erf}\left(\frac{1}{2} \frac{x}{\sqrt{D t}}\right)
$$

Onde: $\quad C_{x}=$ concentração de carbono na posição " $\mathrm{x}$ " [\%]

$\mathrm{C}_{0}=$ teor de carbono no núcleo do material [\%]

$\mathrm{C}_{\mathrm{S}}=$ concentração de carbono na superfície [\%]

$\mathrm{x}=$ distância $[\mathrm{m}]$

$D=$ coeficiente de difusão $\left[\mathrm{m}^{2} / \mathrm{s}\right]$

$\mathrm{t}=$ tempo de processo [s]

erf(z) =função erro para a variável (z). 
Para o cálculo do tempo de cementação utiliza-se o seguinte desenvolvimento axiomático, observando as corretas unidades de medida. Empregando a solução da $2^{a}$ Lei de Fick (Equação 3.3), obtemos a Equação 4.

Aplicando a inversão da função erro na Equação 4 temos a Equação 5:

$\operatorname{erfinv}\left(1-\frac{C_{x}-C_{0}}{C_{s}-C_{0}}\right)=\frac{1}{2} \frac{x}{\sqrt{D t}}=z$

Portanto:

$$
z=\operatorname{erfinv}\left(1-\frac{C_{x}-C_{0}}{C_{s}-C_{0}}\right)
$$

Para o cálculo da "função erro", pode-se utilizar também a Equação 7 cujos valores estão apresentados na Tabela 4 (Mel et al, 1988 apud Baumgarten, 2003).

$$
\operatorname{erf}(z)=\frac{2}{\sqrt{x}} \int_{0}^{x} e^{\left(-y^{2}\right)} d y
$$

Tabela 4. Valores da função erro (Mel et al, 1988, apud Baumgarten, 2003).

\begin{tabular}{|c|c|c|c|c|c|c|c|}
\hline $\mathbf{z}$ & erf (z) & $\mathbf{z}$ & erf (z) & $\mathbf{z}$ & erf (z) & $\mathbf{z}$ & erf (z) \\
\hline 0,00 & 0,00000 & 0,26 & 0,2869 & 0,52 & 0,5379 & 0,78 & 0,7300 \\
\hline 0,01 & 0,01128 & 0,27 & 0,2934 & 0,53 & 0,5465 & 0,79 & 0,7361 \\
\hline 0,02 & 0,02256 & 0,28 & 0,3079 & 0,54 & 0,5549 & 0,80 & 0,7421 \\
\hline 0,03 & 0,03384 & 0,29 & 0,3183 & 0,55 & 0,5633 & 0,81 & 0,7480 \\
\hline 0,04 & 0,04511 & 0,30 & 0,3286 & 0,56 & 0,5716 & 0,82 & 0,7538 \\
\hline 0,05 & 0,05637 & 0,31 & 0,3389 & 0,57 & 0,5798 & 0,83 & 0,7595 \\
\hline 0,06 & 0,06762 & 0,32 & 0,3491 & 0,58 & 0,5879 & 0,84 & 0,7651 \\
\hline 0,07 & 0,07886 & 0,33 & 0,3593 & 0,59 & 0,5959 & 0,85 & 0,7707 \\
\hline 0,08 & 0,09008 & 0,34 & 0,3694 & 0,60 & 0,6039 & 0,86 & 0,7761 \\
\hline 0,09 & 0,1013 & 0,35 & 0,3794 & 0,61 & 0,6117 & 0,87 & 0,7814 \\
\hline 0,10 & 0,1125 & 0,36 & 0,3893 & 0,62 & 0,6194 & 0,88 & 0,7867 \\
\hline 0,11 & 0,1236 & 0,37 & 0,3992 & 0,63 & 0,6270 & 0,89 & 0,7918 \\
\hline 0,12 & 0,1348 & 0,38 & 0,4090 & 0,64 & 0,6346 & 0,90 & 0,7969 \\
\hline 0,13 & 0,1459 & 0,39 & 0,4187 & 0,65 & 0,6420 & 0,91 & 0,8019 \\
\hline 0,14 & 0,1569 & 0,40 & 0,4284 & 0,66 & 0,6494 & 0,92 & 0,8068 \\
\hline 0,15 & 0,1680 & 0,41 & 0,4380 & 0,67 & 0,6566 & 0,93 & 0,8116 \\
\hline 0,16 & 0,1790 & 0,42 & 0,4475 & 0,68 & 0,6638 & 0,94 & 0,8163 \\
\hline 0,17 & 0,1900 & 0,43 & 0,4569 & 0,69 & 0,6708 & 0,95 & 0,8209 \\
\hline 0,18 & 0,2009 & 0,44 & 0,4662 & 0,70 & 0,6778 & 0,96 & 0,8254 \\
\hline 0,19 & 0,2118 & 0,45 & 0,4755 & 0,71 & 0,6847 & 0,97 & 0,8299 \\
\hline 0,20 & 0,2227 & 0,46 & 0,4847 & 0,72 & 0,6914 & 0,98 & 0,8342 \\
\hline 0,21 & 0,2335 & 0,47 & 0,4937 & 0,73 & 0,6981 & 0,99 & 0,8385 \\
\hline 0,22 & 0,2443 & 0,48 & 0,5027 & 0,74 & 0,7047 & 1,00 & 0,8427 \\
\hline 0,23 & 0,2550 & 0,49 & 0,5117 & 0,75 & 0,7112 & 1,10 & 0,8802 \\
\hline 0,24 & 0,2657 & 0,50 & 0,5205 & 0,76 & 0,7175 & 1,20 & 0,9103 \\
\hline 0,25 & 0,2763 & 0,51 & 0,5292 & 0,77 & 0,7238 & 1,50 & 0,9661 \\
\hline
\end{tabular}




\subsubsection{Tratamento Térmico após a Cementação}

\subsubsection{Têmpera}

As peças de aço cementado requerem um processo de endurecimento (têmpera) após a carbonetação, seguido de alívio de tensões (revenimento). A Figura 32 esquematiza a operação de têmpera para o aço ABNT 8630, os pontos $A$, $B, C$ e D indicam o início do resfriamento em função do tempo do tratamento.

A têmpera é um processo de tratamento térmico no qual o aço é aquecido a uma temperatura acima do ponto crítico, mantido nesta temperatura pelo tempo necessário para uniformizar e completar as transformações de fases ao longo da maior seção transversal da peça ou carga. Após uniformização é resfriado rapidamente em óleo, água, sais fundidos ou polímeros.

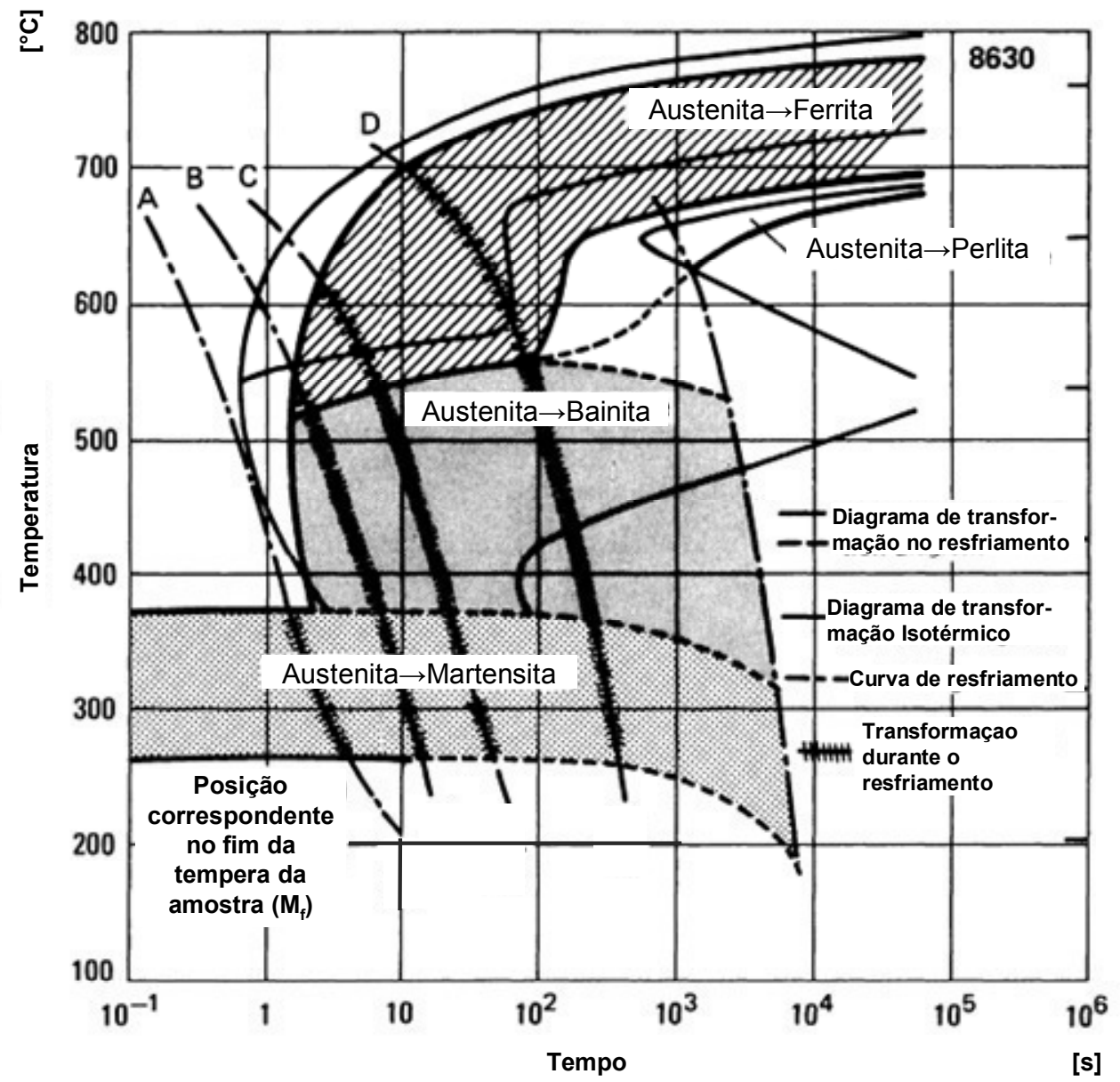

Figura 32. Diagrama de resfriamento contínuo do aço ABNT 8630 cementado (ASM Handbook, 1991). 
A taxa de resfriamento deve ser suficientemente rápida para garantir que a austenita seja super-resfriada até o ponto de transformação da martensita (solução supersaturada de carbono no ferro- $\alpha$ ). Para a maioria dos aços de médio e alto teor de carbono, a martensita obtida após a têmpera tem rede cristalina no sistema tetragonal de corpo centrado (ASM Handbook, 1991), tem característica acicular e as suas principais características são alta dureza e baixa ductibilidade.

A martensita formada a partir da austenita é acompanhada por um acréscimo de volume da ordem de 3\% (Munhoz, 1983 apud Baumgarten, 2003). Esta é a principal razão das altas tensões na peça após o tratamento térmico, que podem causar deformações e trincas na peça tratada. Para se obter uma transformação completa da martensita, o resfriamento do aço deverá ser continuado até a temperatura martensitica final. Após a cementação, a peça pode ser considerada como se tivesse dois materiais diferentes: um na camada cementada, que é um aço eutetóide ou hipereutetóide, e o núcleo que é um aço hipoeutetóide, com a composição original do aço.

Para se obter uma estrutura otimizada sem se lançar mão da operação de dupla têmpera, que além de dispendiosa pode provocar uma descarbonetação ou oxidação superficial nas peças, é utilizada a têmpera direta tanto para aços carbono quanto para aços ligados. As temperaturas para a têmpera mais frequentemente utilizadas em fornos de cementação gasosa variam entre $820^{\circ} \mathrm{C}$ e $860^{\circ} \mathrm{C}$. A estrutura da camada cementada e temperada apresentará estrutura predominantemente martensitica com alguns carbonetos nodulares dispersos e algum teor de austenita retida, provocada ou pelo excesso de carbono ou por uma velocidade de resfriamento não adequada ao aço que está sendo processado. Esta austenita não transformada recebe o nome de austenita retida e pode ser eliminada por uma operação posterior a têmpera, denominada subzero, na qual se continua o resfriamento da peça a temperaturas abaixo de zero.

\subsubsection{Revenimento}

O revenimento é um processo de aquecimento do aço temperado a uma temperatura abaixo do ponto $A_{1}$ do diagrama Fe-C (Figura 24) e mantido por um tempo adequado, com o objetivo básico do aumento da ductilidade e tenacidade do 
aço temperado, eliminando, na medida do possível, os inconvenientes gerados pela têmpera. Como mencionado acima, o aço cementado é constituído de duas estruturas básicas, a martensita tetragonal e a austenita retida, sendo ambos estáveis e que tendem a passar para um estado mais estável com o aquecimento. Esta transformação do aço temperado para um estado mais estável se dá por difusão, portanto, é determinada fundamentalmente pela temperatura de aquecimento. A Figura 33 apresenta as várias possibilidades de temperatura de revenimento para um aço com 0,82\% de C e 0,75\% Mn. Pode-se observar que a temperatura e o tempo de permanência influem diretamente na dureza final da peça.

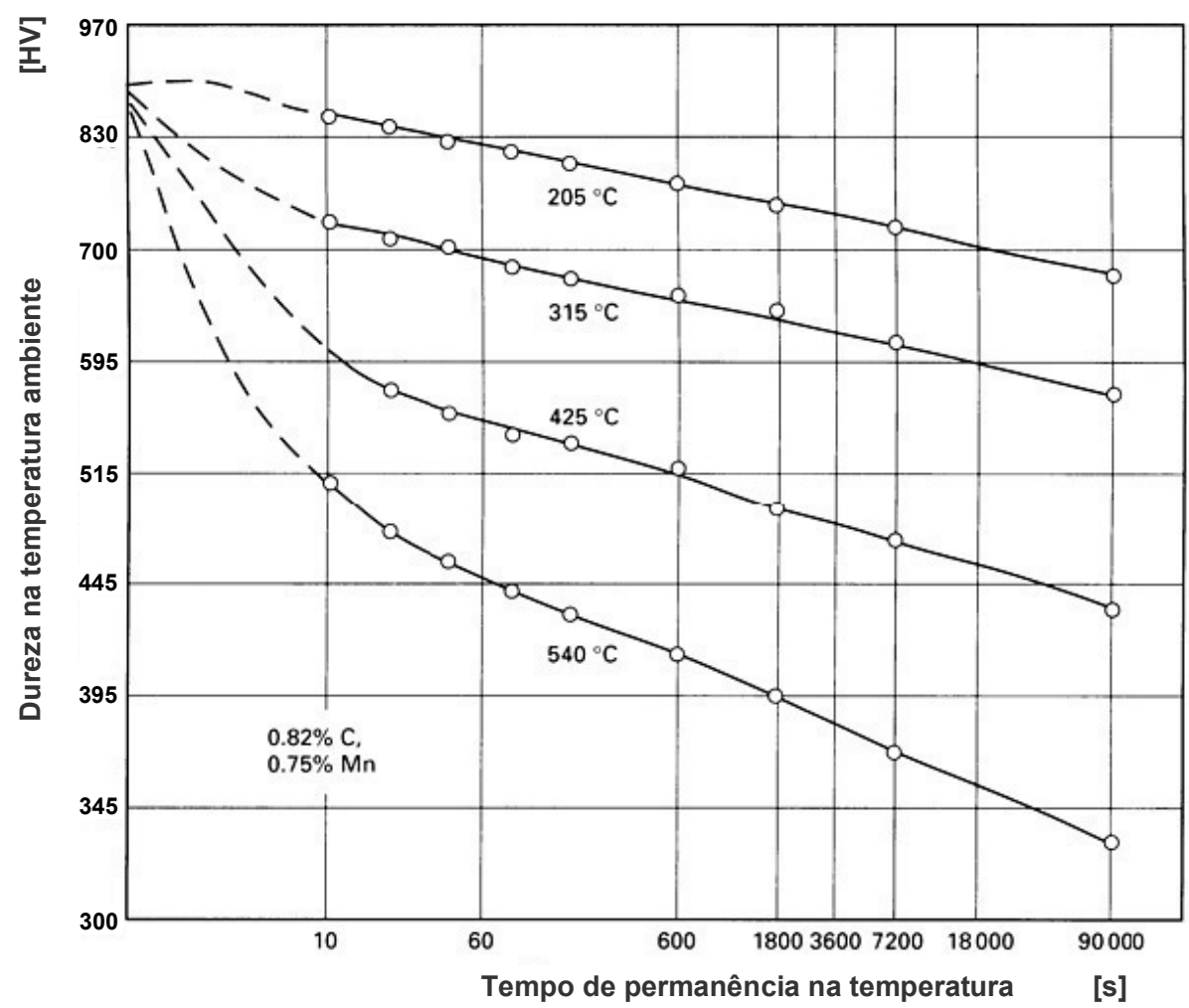

Figura 33. Diagrama de revenimento para aço com 0,82\% de C e 0,75\% Mn (ASM Handbook, 1991).

Para a faixa de temperatura entre $100^{\circ} \mathrm{C}$ e $350^{\circ} \mathrm{C}$ a martensita se decompõe com a precipitação do carbono, na forma de partículas de carbonetos de ferro dispersos (Munhoz, 1983, apud Baumgarten, 2003). Então, como um resultado do revenimento à baixa temperatura têm-se duas soluções sólidas $\mathrm{Fe}-\mathrm{C}$ : TCC/CCC, de martensita além dos carbonetos, uma com baixo e outra com maior teor de carbono (tetragonalidade da martensita). Durante o revenimento, a quantidade de solução sólida Fe-C de maior concentração diminui, enquanto que a de baixa concentração aumenta (Porter, 1981 apud Baumgarten, 2003). 


\subsubsection{Austenita Retida}

Segundo Faria e Munhoz Junior (1990) o estudo do efeito da austenita retida no comportamento mecânico de aços cementados tem sido alvo de muitas discussões e controvérsias. No início, a linha de pensamento dominante entre os pesquisadores conduzia às especificações de microestrutura de camada cementada sem qualquer teor de austenita retida. Elevada dureza superticial e microestrutura totalmente martensítica eram os objetivos, mesmo que para isso fosse necessário tratamento de sub-zero. No entanto, principalmente nas décadas de 60 e 70, alguns autores obtiveram resultados expressivos no efeito benéfico da austenita retida, com casos de melhoria a vida em fadiga de contato com teores de $50 \%$ de austenita retida. Atualmente, as discussões existentes visam esclarecer mecanismos, teor ótimo e distribuição da austenita retida, como também os efeitos positivos e negativos em diversos tipos de solicitação.

A resistência à fadiga de aços cementados tem sido estudada por muito tempo como função de algumas variáveis. Nelas, pode-se incluir profundidade de camada, propriedades e microestrutura do núcleo e da camada, além das tensões residuais. Dessas variáveis, a microestrutura da camada tem sido extensamente estudada, tendo como ênfase o comportamento desta em função dos ciclos de carregamento em fadiga (Faria e Munhoz Junior, 1990).

Observa-se, na superfície de peças cementadas teores de austenita retida inferiores, quando comparadas à regiões abaixo desta. Esta afirmação pode ser vista na Figura 34, para teores de austenita na superfície, e de 0,35 a 0,5 mm de profundidade. $\mathrm{O}$ baixo teor de austenita na superfície é, geralmente, atribuído a outras alterações na composição química superficial (descarbonetação, oxidação) ou a redução de carbono da matriz devido à precipitação de carbonetos. No entanto, se nenhum desses mecanismos atuarem, o teor de austenita retida será mais elevado na superfície, conforme esperado teoricamente pelo maior teor de carbono.

Embora saturada em carbono, a austenita retida possui dureza relativamente baixa e estando presente na camada cementada com martensita de alto carbono (alta dureza) reduz a dureza na superfície do componente cementado. 


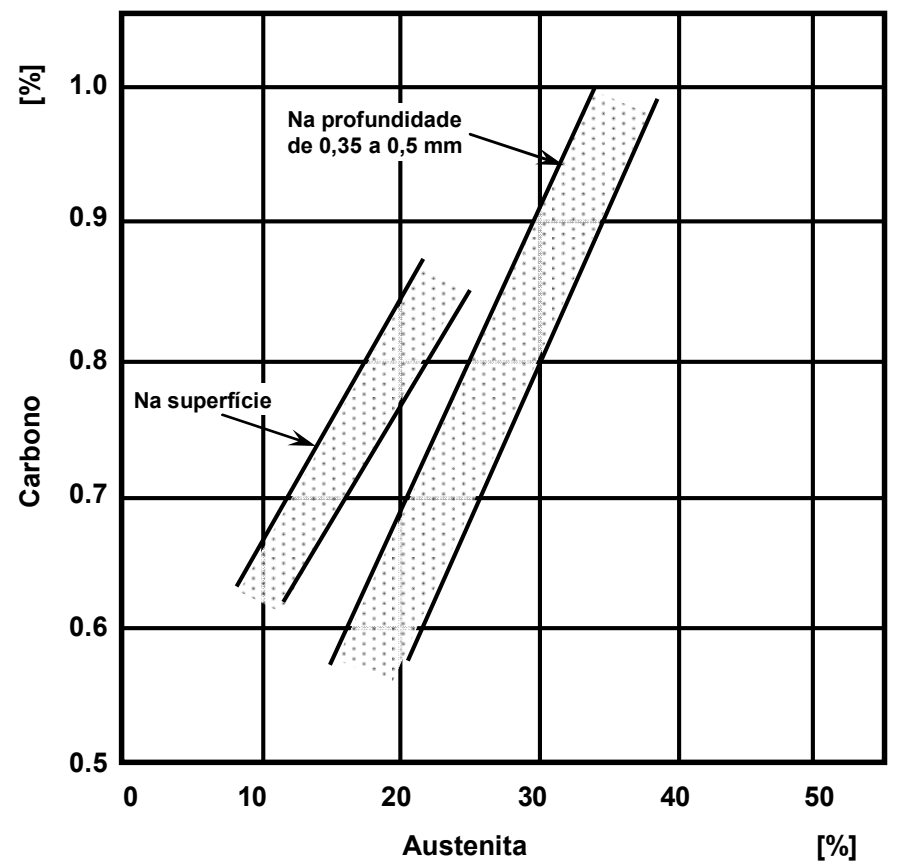

Figura 34. A correlação entre porcentagem de carbono e porcentagem de austenita para componentes cementados(ASM Handbook, 1980, apud Faria e Munhoz Junior, 1990).

Em seu trabalho Faria e Munhoz Junior (1990), tabelaram e compararam resultados obtidos por outros pesquisadores que visaram definir o efeito da austenita retida em aços temperados quando submetidos à fadiga. A Tabela 5 apresenta estas comparações relacionando o efeito da austenita retida quando o material sofre algum tipo de soliciatação (geralmente que induziu o material à fadiga). Nota-se na Tabela 5 efeitos positivos e negativos da austenita retida, dependentes da condição de solicitação e dos teores da austenita.

Tabela 5. Efeito da austenita retida segundo vários pesquisadores (Faria e Munhoz Junior, 1990).

\begin{tabular}{|c|c|c|c|}
\hline Autor & Tipo de solicitação & Aço utilizado & Efeito da austenita \\
\hline Frankel (1959) & Fadiga de contato & AISI 4340 & Negativo \\
\hline Razim (1967) & Fadiga de contato & $16 \mathrm{MnCr} 5$ & Positivo para teores de $50 \%$ \\
\hline litri (1967) & Fadiga de contato & ABNT 8620 & Nenhum \\
\hline $\begin{array}{l}\text { Kozyrev } \\
(1973)\end{array}$ & Fadiga por impacto & $\begin{array}{l}\mathrm{C}: 1,45 \% \text { com } \mathrm{Cr} \\
1,15 \%\end{array}$ & $\begin{array}{l}\text { Positivo para altas cargas e } \\
\text { Negativo para baixas cargas }\end{array}$ \\
\hline $\begin{array}{l}\text { Richman } \\
(1975)\end{array}$ & $\begin{array}{l}\text { Fadiga em tração e } \\
\text { compressão }\end{array}$ & AISI 4027 & Positivo para teores de $20 \%$ a $30 \%$ \\
\hline Krauss (1989) & Fadiga por flexão & $\mathrm{C}-\mathrm{Cr}-\mathrm{Ni}-\mathrm{Mo}$ & $\begin{array}{l}\text { Negativo em alto ciclo e Positivo } \\
\text { em baixo ciclo (teores acima de } \\
15 \% \text { ) }\end{array}$ \\
\hline
\end{tabular}




\subsubsection{Medição da Camada Cementada Endurecida}

A camada endurecida efetiva deve ser controlada para assegurar que a dureza, profundidade de camada e a estrutura final atendam às exigências especificadas para as peças tratadas. Esta profundidade de camada é denominada, em inglês, como "case depth" e em alemão como "Eht" (Einsatzthärtungstief).

Existem diferentes métodos para medir a profundidade da camada, na qual ocorrem mudanças na composição química e propriedades mecânicas em função da profundidade. Cada procedimento tem sua própria área da aplicação e a relação entre a profundidade de camada e o método de medição pode variar bastante.

A profundidade efetiva da camada é a distância perpendicular à superfície ao ponto mais distante, no qual o valor especificado da dureza é mantido. O critério do limite da dureza é, de acordo com a norma DIN 50 190, de 550 HV1 (dureza de acordo com o método Vickers com carga de $9,8 \mathrm{~N}$ ) ou $50 \mathrm{HRC}$, ou equivalente, quando se considera um teor de carbono de aproximadamente $0,50 \%$ neste ponto, conforme apresenta a Figura 35.

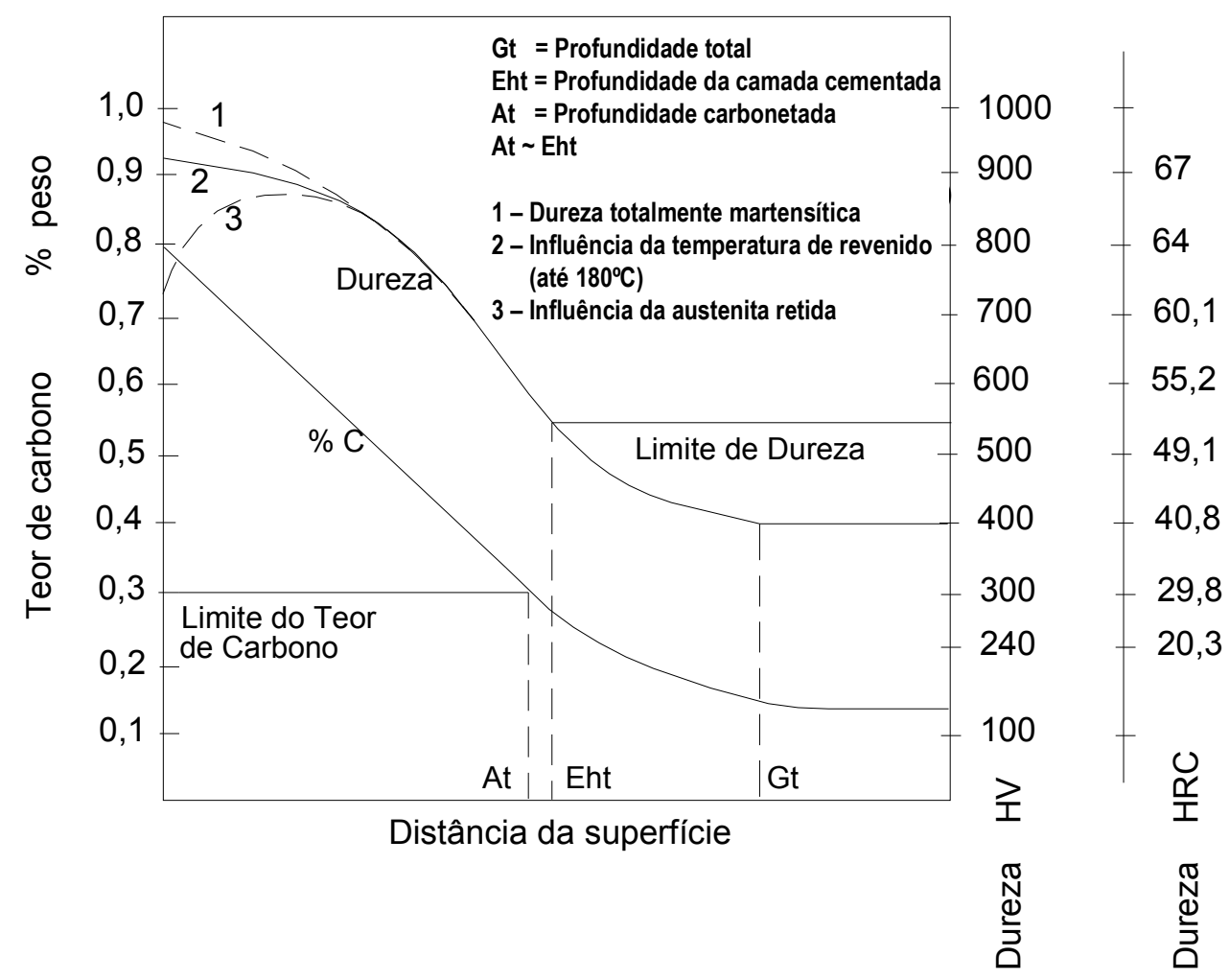

Figura 35. Distribuição esquematizada da profundidade da concentração de carbono e da dureza em uma peça cementada (Macherauch, 1992). 
A medição deverá ser feita em corpos de prova com a mesma condição de tratamento da peça ou diretamente na peça, sendo neste caso um exame destrutivo, que consiste na medição de um perfil de dureza em um corte no sentido transversal à peça (e à camada) ou corpo de prova. O corte deverá ser feito cuidadosamente a fim de evitar o fenômeno do revenimento ou da retêmpera provocado por incorreções no processo de corte. A preparação metalográfica do corpo de prova na seção transversal deve ser feita de forma a não afetar a medição das impressões da dureza, significando, assim, que quanto mais leve for a carga escolhida melhor deverá ser a qualidade do polimento.

As impressões de dureza deverão ser feitas seguindo uma linha imaginária perpendicular à superfície. A primeira endentação a ser feita a partir da superfície deverá estar a uma distância tal, que assegure suporte metálico suficiente entre o centro da impressão e a superfície. As impressões subseqüentes deverão estar afastadas o suficiente para não afetar o valor da dureza subseqüente a ser medida. Esta dimensão de acordo com a norma ASTM E18 deverá ser no mínimo de 2,5 vezes o diâmetro da endentação. 


\subsection{Torneamento de Materiais Endurecidos}

O torneamento de materiais endurecidos, segundo Lima (2001), é um processo de usinagem de materiais com dureza superior a $600 \mathrm{HV}$ (55 HRC) com uso de ferramentas monocortantes. Segundo Matsumoto e Diniz (1998), uma das principais vantagens do torneamento de materiais endurecidos é poder-se obter dimensões finais da peça, dispensando-se o processo da retificação, gerando com isto, um baixo custo de produção e maior produtividade. Abrão (2005) afirma também a vantagem de se eliminar o risco de distorções durante a etapa de tratamento térmico e o subseqüente retrabalho. As forças de corte envolvidas no torneamento endurecido segundo Abrão (2005) podem chegar a ser $80 \%$ superiores quando comparadas ao torneamento de materiais não endurecidos.

\subsubsection{Mecânica do Corte na Usinagem Ortogonal}

Embora as operações mais comuns sejam as de usinagem em casos geométricos tridimensionais ou condição de corte oblíqua, o estudo do caso simples de duas dimensões ortogonais de corte é utilizado para explicar o mecanismo geral da remoção de material em usinagem.

Altintas (2000) apresenta a uma abordagem do corte ortogonal onde o material é removido por uma aresta de corte que está perpendicular à direção do movimento relativo ferramenta-peça. A mecânica das operações com corte oblíquo é normalmente avaliada pela transformação geométrica e cinemática de modelos aplicados ao processo de corte ortogonal. Representações de processos de corte ortogonal e oblíquo são apresentadas nas Figuras 36 e 37 respectivamente, ondeo corte ortogonal se assemelha a um processo de moldagem com uma ferramenta reta cuja ponta é perpendicular à velocidade de corte $\left(V_{c}\right)$. Um cavaco metálico com uma largura de corte (b) e espessura (h) é cisalhado para fora da peça. No corte ortogonal, o processo é presumido como uniforme ao longo da aresta de corte, portanto é um processo plano de deformações, sem fluxo lateral de material. Por 
este motivo as forças de corte são aplicadas somente nas direções da velocidade de corte $\left(V_{c}\right)$ e da espessura do cavaco ainda não cortado, que são chamadas de força tangencial $\left(F_{t}\right)$ e força de avanço ou passiva $\left(F_{f}\right)$. Contudo em corte obliquo a aresta de corte é orientada com um ângulo de inclinação (i) e existe uma terceira força agindo na direção radial $\left(F_{r}\right)$ Figura 37.

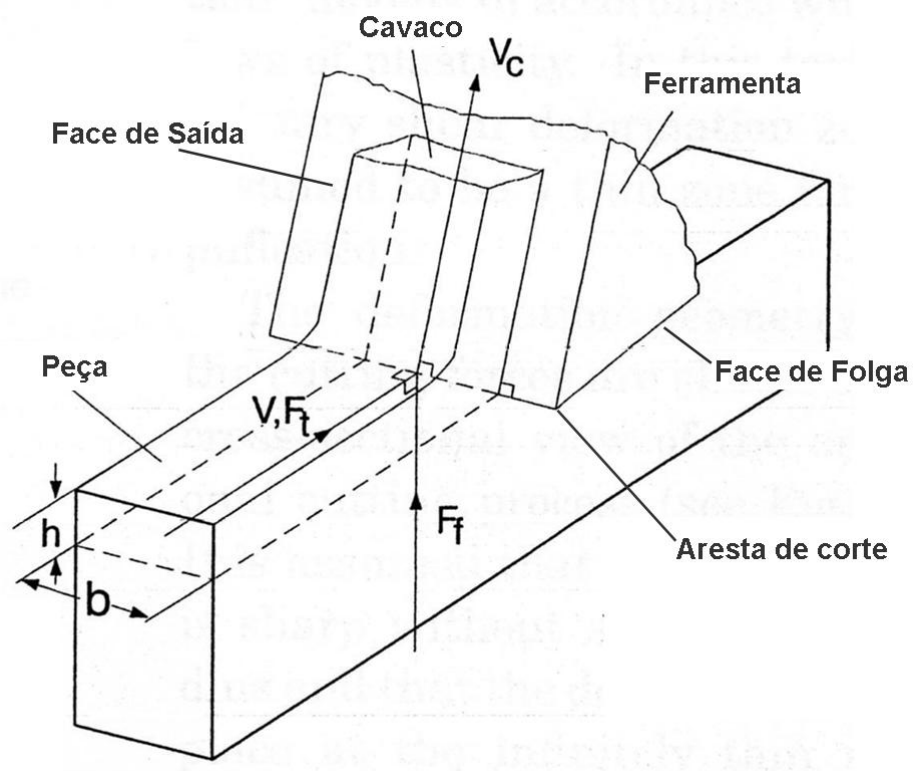

Figura 36. Geometria do corte ortogonal (Altintas, 2000).

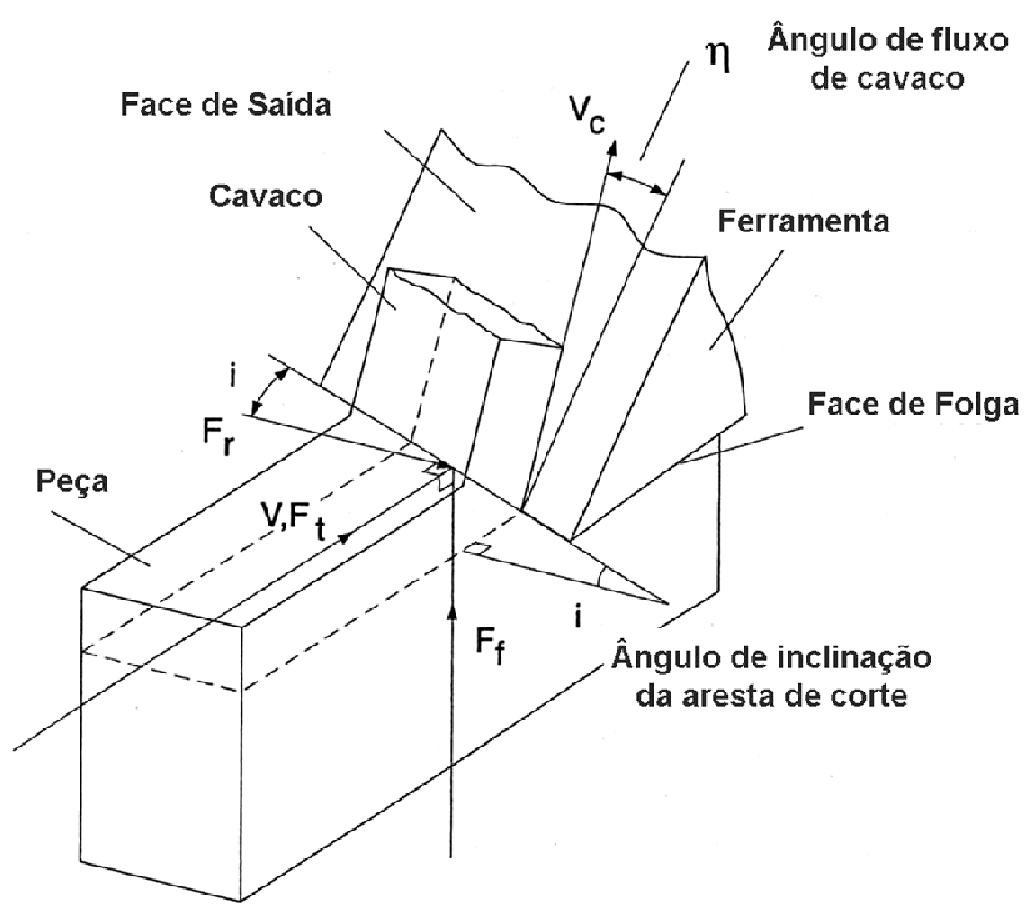

Figura 37. Geometria do corte oblíquo (Altintas, 2000). 


\subsubsection{Zonas de Cisalhamento}

Segundo Griffiths (2001), Altintas (2000) e Toenshoff et al (2000) existem três zonas de deformação por cisalhamento no processo de corte como apresenta a Figura 38.

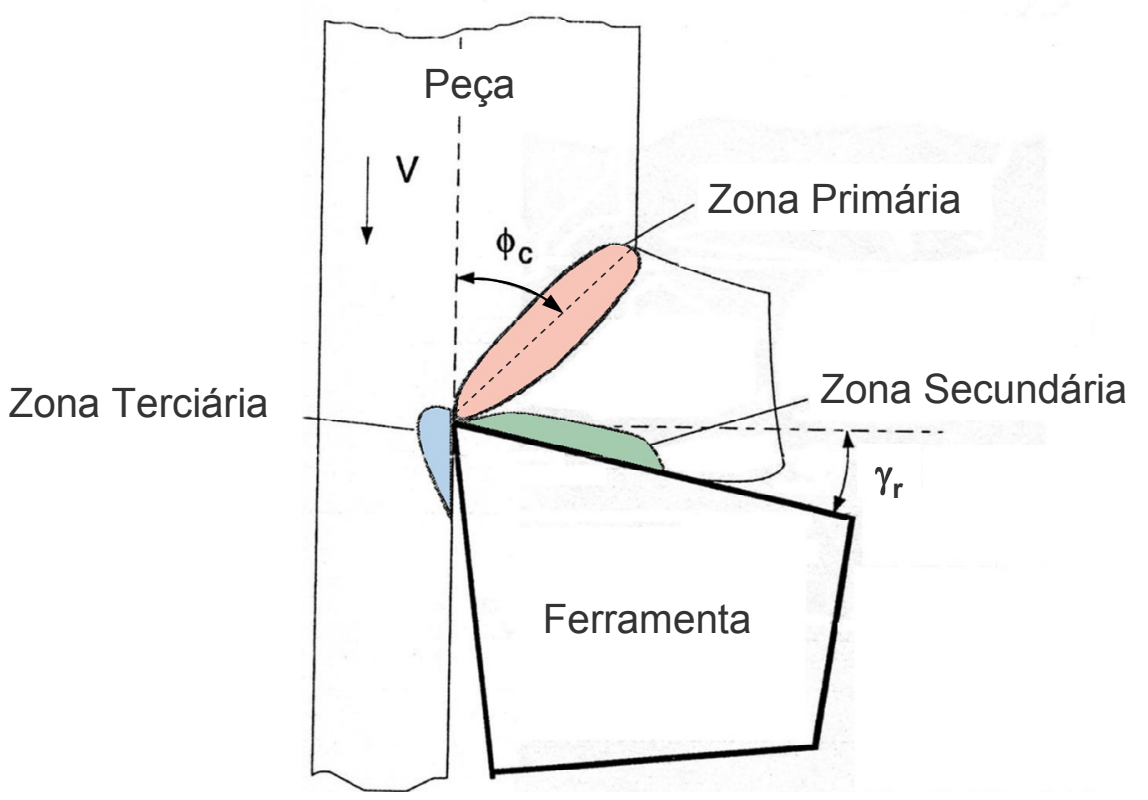

Figura 38. Zonas de deformação por cisalhamento (Altintas, 2000 e Griffiths, 2001).

O cisalhamento primário ocorre quando o material da peça é convertido em cavaco, isto é, quando é deformado e cisalhado pelo material que se encontra em contato com a face de saída da ferramenta. O cisalhamento secundário ocorre quando a parte inferior do cavaco atrita com a face de saída da ferramenta durante a passagem para fora da zona de corte. O cisalhamento terciário ocorre quando a parte inferior da ferramenta (pela face de folga) atrita contra a nova superfície. Os cisalhamentos primários e terciários afetam a superfície gerada da peça enquanto o secundário não. O evento unitário no torneamento é, portanto a combinação dos eventos unitários de cisalhamento primário e terciário.

Uma descrição do evento unitário do processo de corte é feita por Altintas (2000) onde o cavaco inicialmente adere à face de saída da ferramenta, a tensão de atrito é aproximadamente igual à tensão de escoamento do material na face de 
saída onde o cavaco se move sobre o material aderido na face de saída. O cavaco para de aderir e começa a deslizar sobre a face com um coeficiente constante de atrito. O cavaco se solta da ferramenta perdendo o contato com a face de saída da ferramenta, Figura 39.

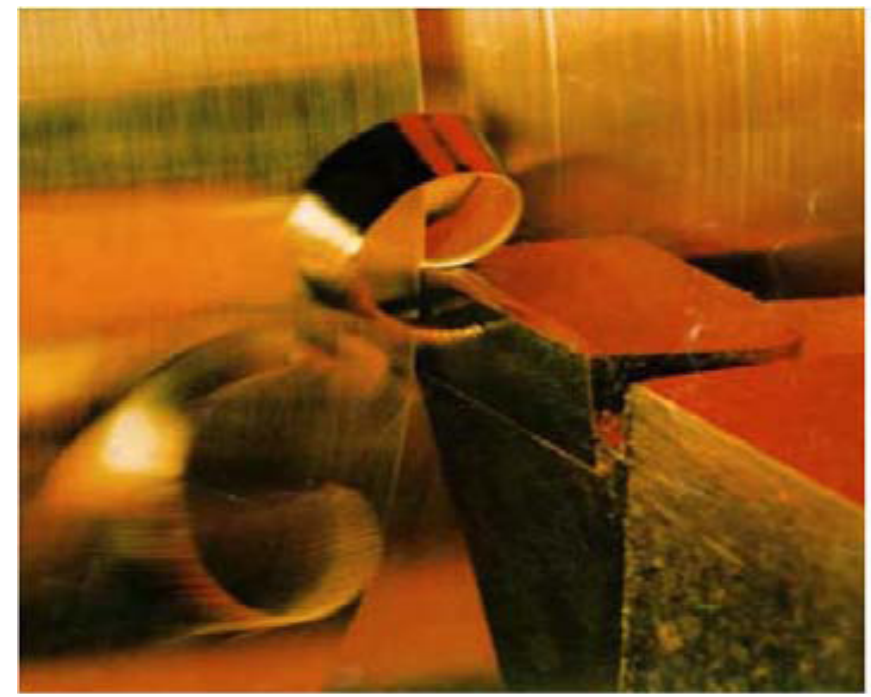

Figura 39. Arranque de cavaco na usinagem de torneamento obliquo (Rech, 2005).

A Figura 40 apresenta um diagrama das forças de corte envolvidas no processo ortogonal. Simplificando, assume-se que a aresta de corte é afiada, sem chanfro ou raio de arrendondamento e a deformação ocorre em uma plano infinitesimalmente fino (Altintas, 2000). O ângulo de cisalhamento $\phi_{c}$ é definido como o ângulo entre a direção da velocidade de corte $\left(V_{c}\right)$ e o plano de cisalhamento. Assume-se que a tensão de cisalhamento $\left(\tau_{s}\right)$ e a tensão normal $\left(\sigma_{s}\right)$ no plano de cisalhamento são constantes.

A força resultante $(F)$ no cavaco aplicada no plano de cisalhamento está em equilibrio com a força aplicada a ferramenta sobre a zona de contato ferramentacavaco na face de saída, e presume-se uma constante de atrito média na zona de contato cavaco-ferramenta. Do equilíbrio das forças, a força resultante $(F)$ é formada, então, pela força de avanço $\left(F_{f}\right)$ e força tangencial $\left(F_{t}\right)$, conforme Equação 8 (Altintas, 2000). Esta nomenclatura pode variar de acordo com sistema utilizado pelo autor em questão. Em vários traballhos se encontra a nomenclatura de força de 
passiva $\left(F_{p}\right)$ como força de avanço e força de corte $\left(F_{c}\right)$ como força tangencial. Nesta discussão utilizaremos a definição de Altintas, 2000.

$$
\boldsymbol{F}=\sqrt{F^{2}+F_{f}^{2}}
$$

A força de avanço está na direção da espessura do cavaco não cortado e a força tangencial está na direção da velocidade de corte. As forças de corte que agem na ferramenta possuem a mesma amplitude mas direções opostas relativas às forças que agem no plano de cisalhamento primário.

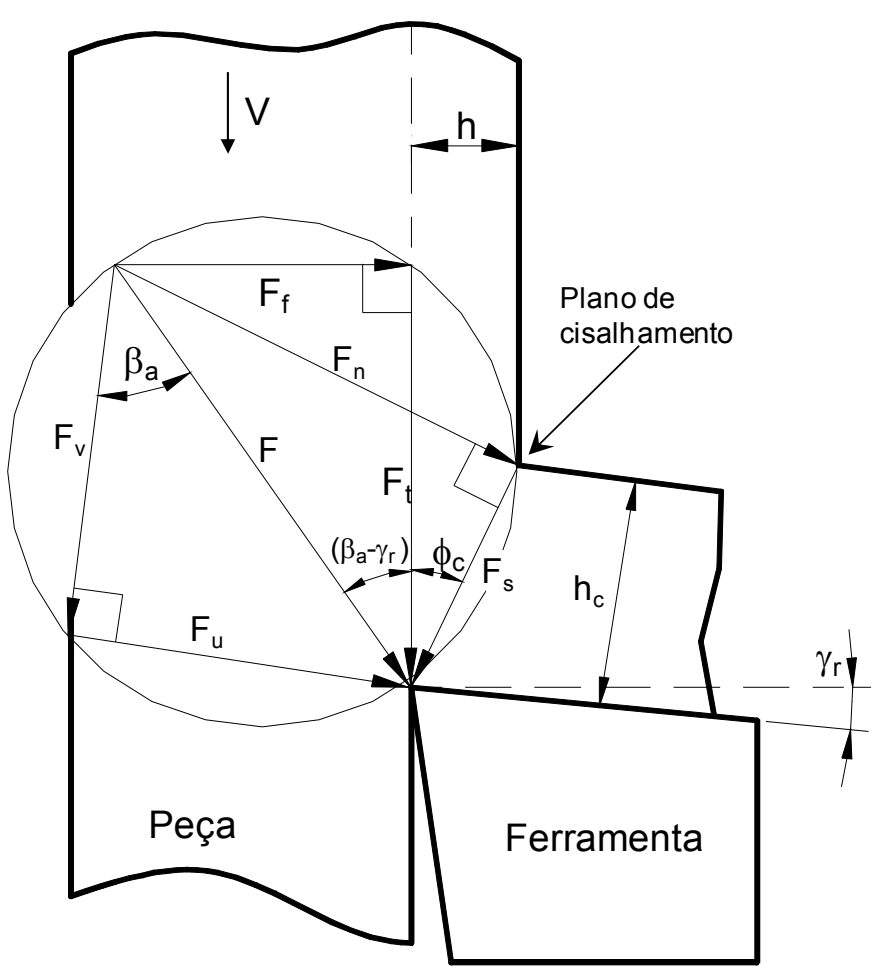

Figura 40. Diagrama de forças no corte ortogonal (Altintas, 2000).

\subsubsection{Zona de Cisalhamento Primária}

A força de cisalhamento $\left(F_{s}\right)$ Equação 9 principal força agindo no plano da zona de cisalhamento primário e sua força normal $\left(F_{n}\right)$, Equação 10, são derivadas da geometria da Figura 40: 


$$
\begin{aligned}
& F_{s}=F \cos \left(\phi_{c}+\beta_{a}-\gamma_{r}\right) \\
& F_{n}=F \operatorname{sen}\left(\phi_{c}+\beta_{a}-\gamma_{r}\right)
\end{aligned}
$$

Onde $\beta_{a}$ é o ângulo médio de atrito entre a face de saída da ferramenta e o cavaco em movimento, $\phi_{\mathrm{c}}$ é definido como o ângulo entre a direção da velocidade de corte $\left(V_{c}\right)$ e o plano de cisalhamento, e $\gamma_{r}$ é o ângulo de saída da ferramenta.

As forças de cisalhamento também podem ser expressas como função da força tangencial $\left(F_{t}\right)$ e de penetração $\left(F_{f}\right)$ como mostram as Equações 11 e 12:

$$
\begin{aligned}
& F_{s}=F_{t} \cos \phi_{c}-F_{f} \operatorname{sen} \phi_{c} \\
& F_{n}=F_{t} \operatorname{sen} \phi_{c}-F_{f} \cos \phi_{c}
\end{aligned}
$$

Assumindo distribuição uniforme de tensões no plano de cisalhamento, a tensão de cisalhamento $\left(\tau_{\mathrm{s}}\right)$ e a tensão normal $\left(\sigma_{\mathrm{s}}\right)$ podem ser descritas nas Equações 12 e 13:

$$
\begin{gathered}
\tau_{s}=\frac{F_{s}}{A_{s}} \\
\sigma_{s}=\frac{F_{n}}{A_{s}}
\end{gathered}
$$

Onde a área do plano de cisalhamento (As) é definida como (Equação 15):

$$
A_{s}=b \frac{h}{\operatorname{sen} \phi_{c}}
$$

Sendo b a largura de corte, h espessura de corte do cavaco e $\phi_{c}$ definido como o ângulo entre a direção do velocidade de corte $\left(V_{c}\right)$ e o plano de cisalhamento. 


\subsubsection{Zona de Cisalhamento Secundária}

$\mathrm{Na} z o n a$ de cisalhamento secundária existem duas componentes atuantes na face de saída da ferramenta a força normal $\left(F_{v}\right)$ Equação 16, e a força de atrito $\left(F_{u}\right)$ Equação 17:

$$
\begin{aligned}
& F_{v}=F_{t} \cos \gamma_{r}-F_{f} \operatorname{sen} \gamma_{r} \\
& F_{u}=F_{t} \operatorname{sen} \gamma_{r}+F_{f} \cos \gamma_{r}
\end{aligned}
$$

Nesta análise de corte ortogonal assume-se que o cavaco desliza sobre a face de saída com uma constante de atrito $\mu_{\mathrm{a}}$. Segundo Zorev, (1963 apud Altintas 2000) o cavaco adere na superfície de saída por um curto período e então desliza sobre a face de saída com este coeficiente de atrito $\mu_{\mathrm{a}}$. A Equação 18 apresenta este coeficiente com sendo:

$$
\mu_{a=} \tan \beta_{a}=\frac{F_{u}}{F_{v}}
$$

Onde $\beta_{a}$ é designado como o ângulo de atrito e pode ser obtido como função das forças tangencial e de penetração (Equação 19):

$$
\beta_{a}=\gamma_{r}+\tan ^{-1} \frac{F_{f}}{F_{t}}
$$

\subsubsection{Geometria da Ponta da Ferramenta}

O formato da ponta da ferramenta irá deixar uma topografia na superfície, Figura 41. Este é um típico formato afiletado que se repete na frequência correspondente ao avanço. Deformações subsuperficiais e transformações térmicas dependem da deformação das zonas de cisalhamento primárias e terciárias (Griffiths, 2001). 


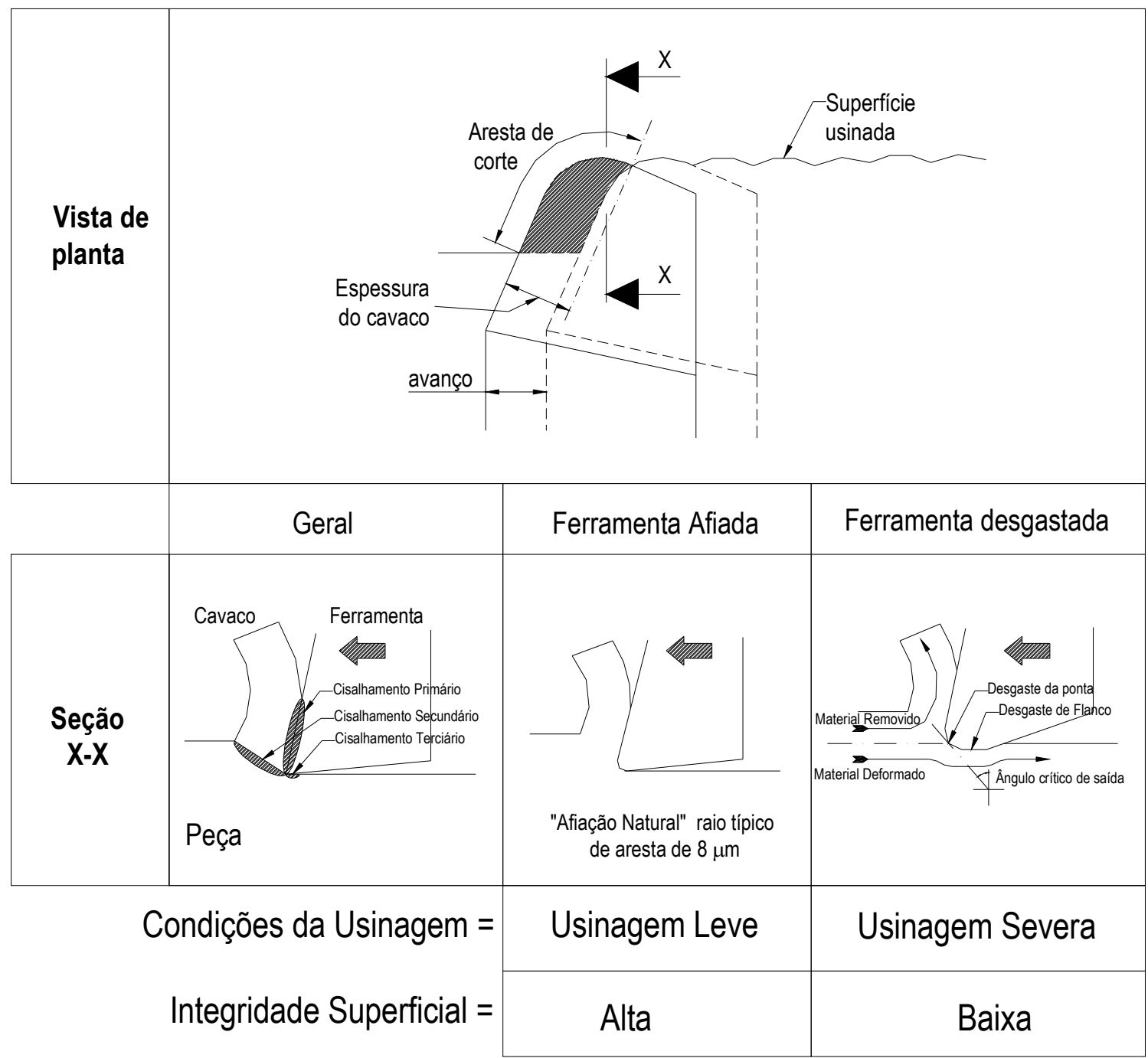

Figura 41. Formato deixado pela usinagem em torneamento (Griffiths, 2001).

Segundo Warren e Guo (2007), o torneamento produz um perfil de corte uniforme, seu formato pode ser diretamente controlado pela geometria da ferramenta, profundidade de corte e avanço da ferramenta. A Figura 42 apresenta uma imagem óptica do resultado de torneamento em aço endurecido ABNT 52100, com $V_{c}=119 \mathrm{~m} / \mathrm{min}, \mathrm{f}=0.0508 \mathrm{~mm} / \mathrm{rot}, a_{p}=0.254 \mathrm{~mm}$ e usinagem a seco.

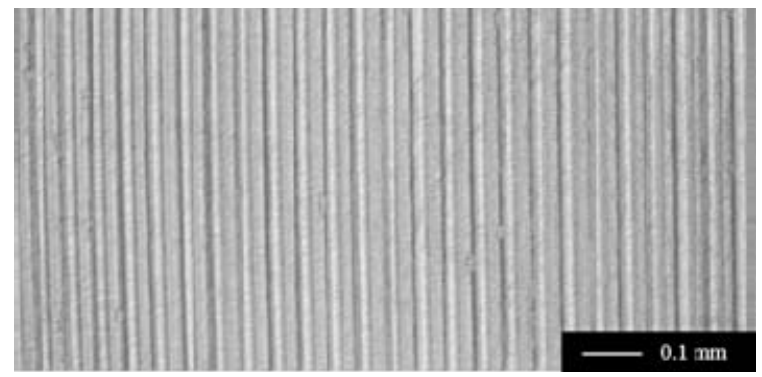

Figura 42. Imagem óptica da superfície usinada em torneamento (Warren e Guo, 2007). 
Mais recentemente, visando melhorar a condição de produtividade e qualidade superficial das peças, os fabricantes de ferramentas tem investindo no desenvolvimento de novas geometrias de corte, mais elaboradas e projetadas em função de resultados específicos. A Figura 43 apresenta um destes exemplos, conhecida comercialmente como geometria "Wiper", tecnicamente chamada por Grzesik (2008b) de multi-raio ou fase alisadora por Oezel et al (2007). Ela apresenta uma ponta mais elaborada que possibilita uma redução de metade do valor nos picos de rugosidade com mesmo avanço ou o dobro do avanço para a mesma rugosidade obtida com ponta convencional (Oezel et al, 2007). Para o caso de torneamento de material endurecido em substituição à retificação, se faz necessário uma menor rugosidade superficial, portanto este tipo de ponta é o mais apropriado.

(a)

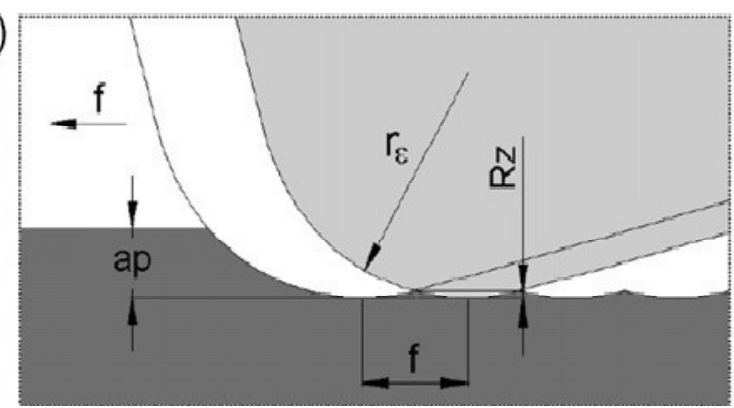

(b)

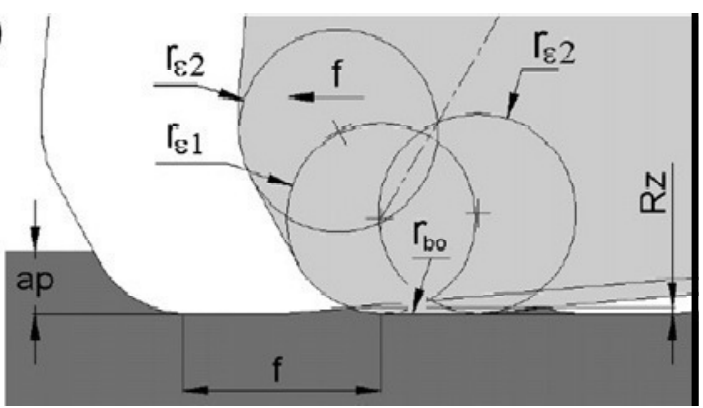

Figura 43. Ponta com geometria convencional(a) e multi-raio wiper (b). (Grzesik, 2008b).

Sendo:

f: avanço

$a_{p}$ : profundidade de corte

$r_{\varepsilon}$ : raio de ponta

$r_{\varepsilon 1}$ e $r_{\varepsilon 2}$ : raio de curvatura Wiper

$r_{\mathrm{bo}}$ : raio de alisamento

Rz: altura do vale até o pico

\subsubsection{Fatores de Influência nas Forças de Usinagem}

O ângulo de saída exerce um papel importante, pois, quanto mais negativo, mais o material adiante da ferramenta é forçado para frente sendo comprimido contra a superfície. Quando o ângulo de saída atinge certo valor o evento unitário 
muda de corte para conformação onde um acúmulo de material se forma na frente da ferramenta. Com o corte o material é removido da peça em forma de cavaco que escorrega sob a face de saída da ferramenta, mas sem o corte, o material é empurrado na frente da ferramenta. Se não ocorrer o fluxo lateral, o acúmulo de material irá continuar a crescer, eventualmente se formando instável e se tornando um fragmento descontínuo.

A Figura 44 mostra uma fotomicrografia da formação de um acúmulo de material, efetuado em experimento de parada rápida de torneamento usando uma ferramenta com ângulo de saída $\gamma=-70^{\circ}$.

O efeito mecânico não é o único a fazer parte do evento unitário, adicionalmente existe o efeito térmico. As temperaturas associadas ao corte de material são variadas. Se a ferramenta é afiada, as temperaturas geradas serão comparativamente baixas. No entanto, se existe desgaste de ferramenta, a temperatura irá aumentar dramaticamente (Toenshoff et al, 2000). Temperaturas em torno de $700^{\circ} \mathrm{C}$ no flanco da ferramenta já foram observadas em estudos anteriores. Quando comparamos esta temperatura com a temperatura de transformação de fase do aço $\left(723^{\circ} \mathrm{C}\right)$ podemos observar que facilmente podem ocorrer transformações martensíticas nas camadas superficiais da peça (Griffiths, 2001).

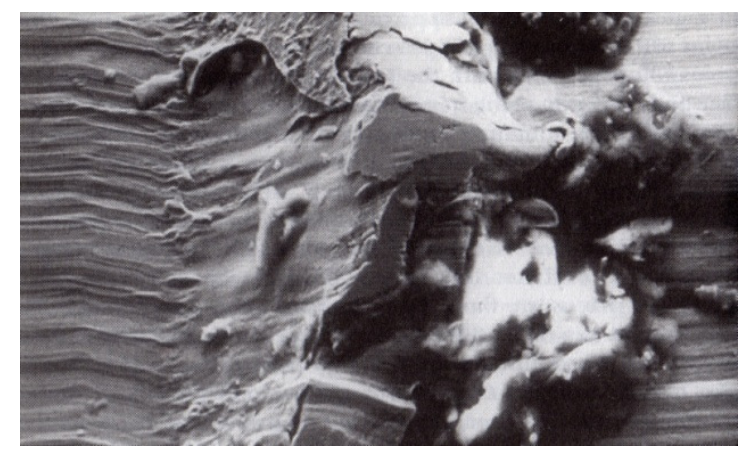

Figura 44. Acúmulo de material com ferramenta de ângulo de saída de $-70^{\circ}$ (Griffiths, 2001).

Segundo Qian e Hossan (2007) o ângulo de saída influencia levemente as forças de usinagem, fato observado em seu estudo de torneamento em vários aços como ABNT 52100, ABNT 4340 e SAE D2 com 700 a 750 HV de dureza (60 a 62 HRC aproximadamente) e SAE H13 com 600 HV de dureza (50 a 55HRC de dureza aproximadamente). Verificaram que uma variação de $20^{\circ}$ no ângulo de saída não provovou uma significativa mudança no comportamento da força de corte, Figura 45. 


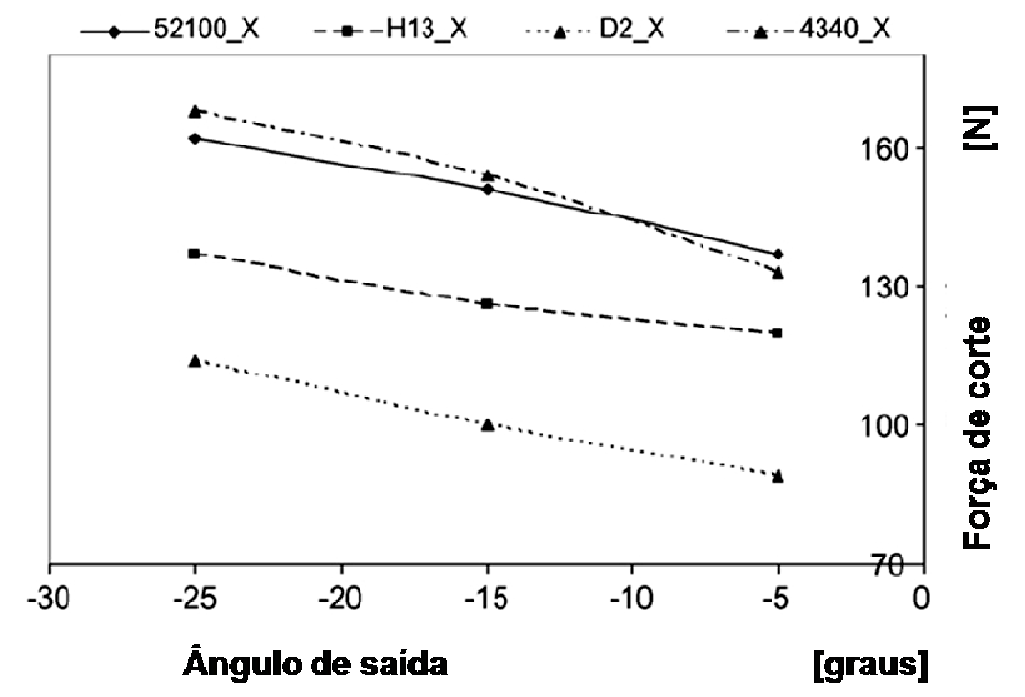

Figura 45. Efeito do ângulo de saída na força de corte para vários materiais (Quian e Hossan, 2007).

Eredel (1998), apud Grzesik (2008a) analisou as forças de corte envolvidas no torneamento do aço ABNT 5115 (16 MnCr 5) com dureza de 700 a $750 \mathrm{HV}$ de dureza (60-62 HRC aproximadamente) e relacionou suas grandezas em função do tempo de corte, portanto em funçao da vida da ferramenta como mostra a Figura 46.

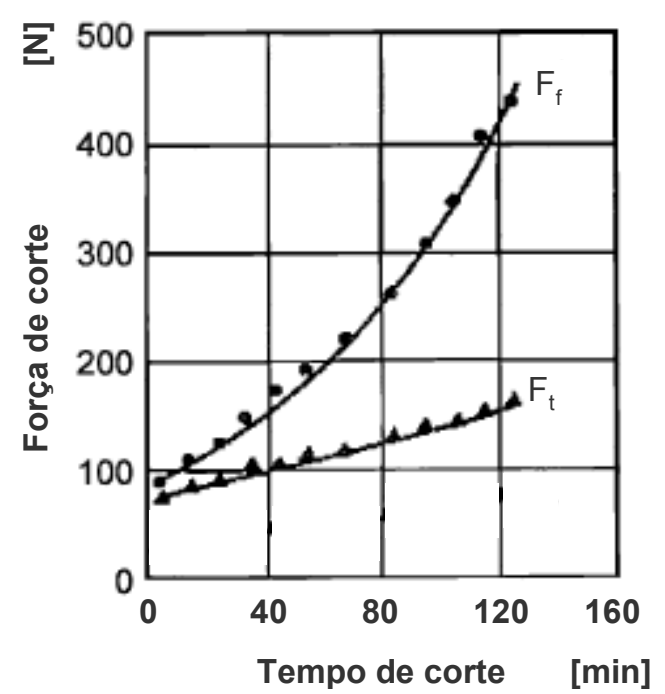

Figura 46. Forças no corte ortogonal em funçao do tempo, ferramenta em $c B N, V_{c}=145 \mathrm{~m} / \mathrm{min} e$ $a_{p}=0.2 \mathrm{~mm}$ (Eredel, 1998 apud Grzesik, 2008a).

Em relação às componentes da força de usinagem, o processo de torneamento de materiais endurecidos difere do processo convencional de torneamento. Enquanto que no torneamento de material não endurecido (dureza 
abaixo de $600 \mathrm{HV}$ ou $55 \mathrm{HRC}$ ) a relação $F_{t} / F_{f}$ é maior do que um, no torneamento de materiais endurecidos (dureza acima de $600 \mathrm{HV}$ ou $55 \mathrm{HRC}$ ), essa relação é menor do que um (Delijaicov, 2004).

A força de passiva $\left(F_{p}\right)$ é a maior das componentes dentre as demais forças no processo de torneamento de materiais endurecidos, fato devido à geometria de aresta negativa. Em decorrência deste fato, este esforço passa a ser um fator de influência importante no nível de tensões residuais introduzidas na superfície e subsuperfície da peça usinada. Por outro lado, o desgaste da ferramenta, durante a operação de usinagem, provoca um aumento no valor das componentes da força total de usinagem. Toenshoff et al (1994) apud Lima (2001) apresenta a influência da velocidade de corte e do desgaste nas forças de usinagem, no torneamento do aço ABNT 5115, com ferramentas cerâmicas com avanço de 0,1 mm/rot e profundidade de penetração de $0,2 \mathrm{~mm}$. A Figura 47 ilustra os resultados obtidos pelos pesquisadores, que confirmam as afirmações anteriores quanto aos valores das componentes do esforço total de usinagem. Afirmam, ainda, que o calor gerado na zona de corte é suficiente para amolecer o material da peça, facilitando a operação de corte e consequentemente diminuindo o respectivo esforço.

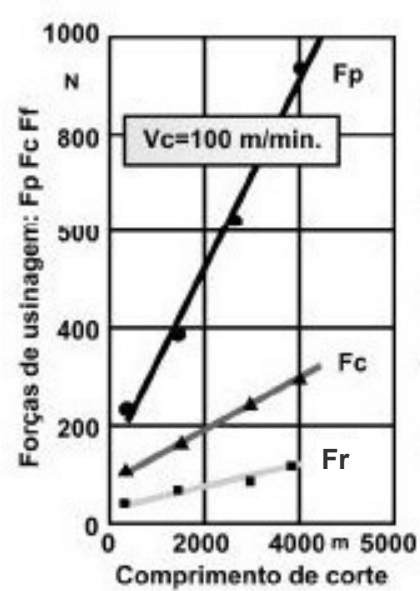

(a)

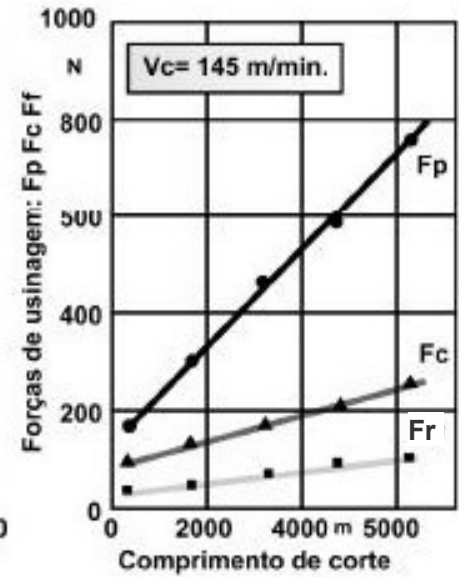

(b)

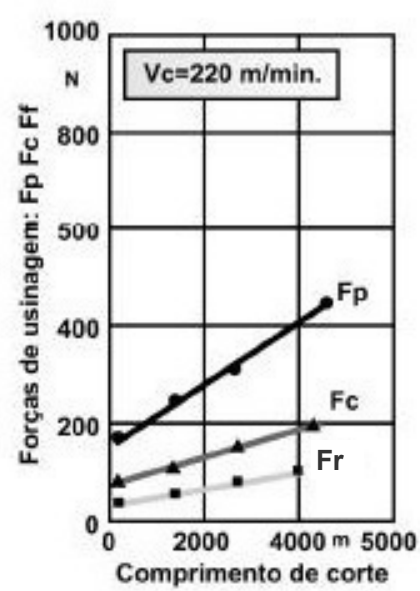

(c)

Figura 47. Efeito da velocidade de corte e do desgaste de flanco nas componentes da força de usinagem (a) $V_{c}=100 \mathrm{~m} / \mathrm{min}$, (b) $V_{c}=145 \mathrm{~m} / \mathrm{min}$ e (c) $V_{c} 220 \mathrm{~m} / \mathrm{min}$.

(Toenshoff et al, 1994 apud Lima, 2001).

Sendo $\left(F_{p}\right)$ como a força passiva e $\left(F_{c}\right)$ força tangencial, como se trata de um estudo em condições obliquas a força lateral ou de avanço lateral é representada por $\left(F_{r}\right)$. 


\subsubsection{Formação do Cavaco na Usinagem de Material Endurecido}

No processo de torneamento de materiais endurecidos, elevadas tensões de compressão são introduzidas na peça usinada devido a ação da ponta da ferramenta contra a superfície de trabalho. A ação conjunta da força de penetração e do avanço gera tensões residuais na superfície e subsuperfície da peça. Abrão e Aspinwall et al(1995), tornearam peças em aço ABNT 52100 com $750 \mathrm{HV}$ (aproximadamente $62 \mathrm{HRC}$ ) com ferramentas de cBN, e mediram os respectivos esforços de usinagem. Constataram que as forças passiva eram maiores que as forças de corte e avanço, fato que contrasta com os resultados do processo convencional de torneamento onde as maiores forças são as de corte e avanço, respectivamente. Segundo Koenig et al (1990), estas elevadas tensões de compressão fazem com que a superfície da peça plastifique e cisalhe, formando assim o cavaco Figura 48.

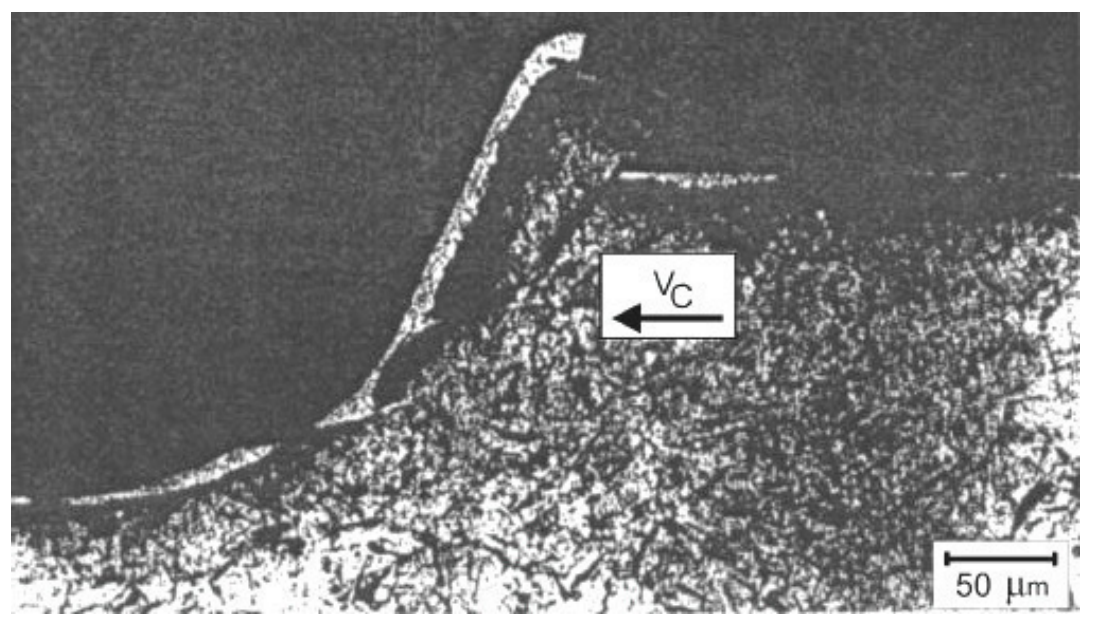

Figura 48. Formação do cavaco no torneamento de materiais endurecidos (Koenig et al, 1990).

Este mecanismo se dá pela liberação da energia armazenada no material endurecido, após a ocorrência da fissura a partir da superfície da peça. Segue-se a deformação plástica do cavaco e seu respectivo deslizamento, gerando calor e aquecendo a zona de contacto metal ferramenta Poulachon e Moisan (1998). Assim 
que essa quantidade de material for removida, o processo se repete e um cavaco longo de perfil serrilhado se forma Figura 49.

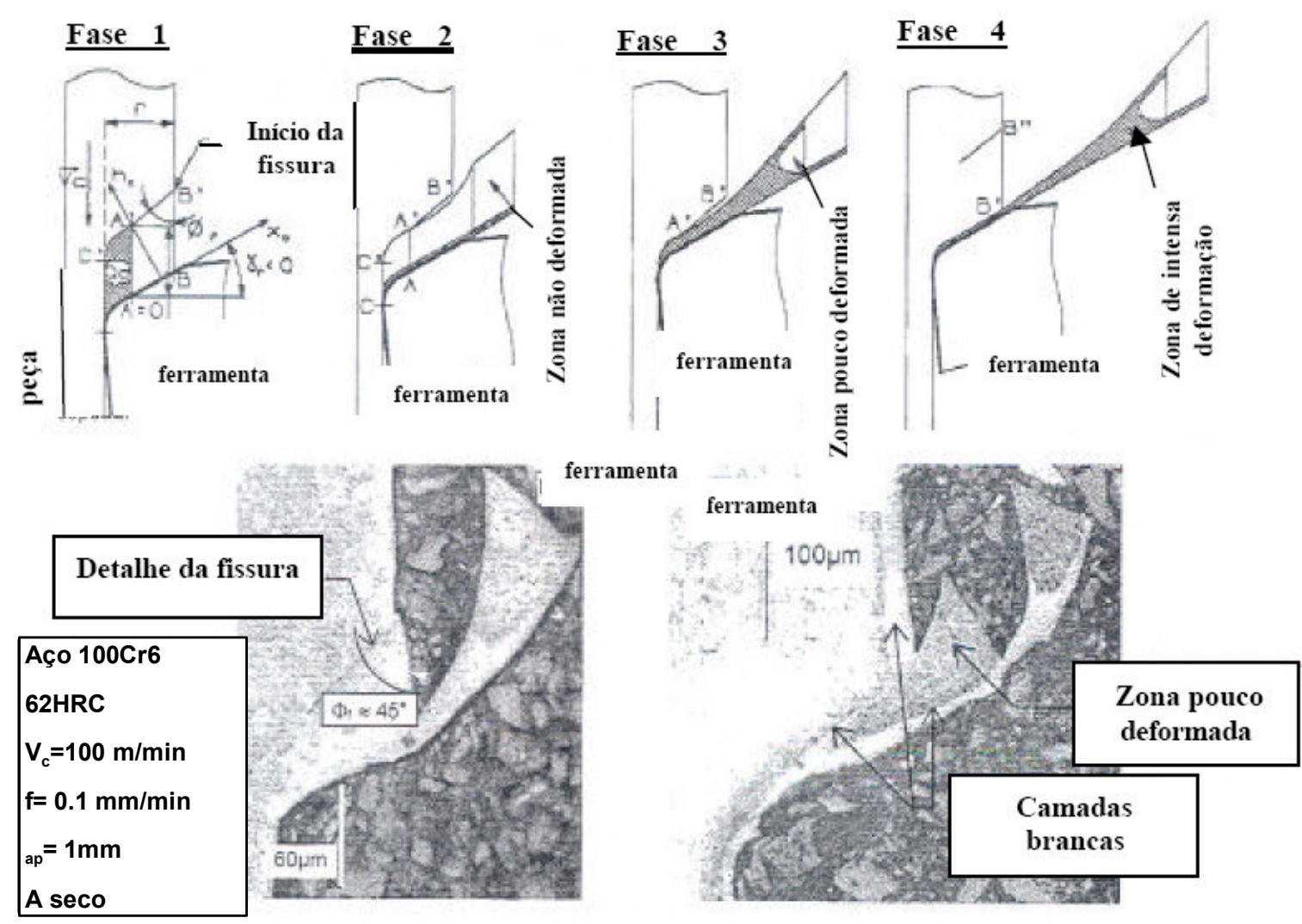

Figura 49. Formação do cavaco em perfil dente de serra (Poulachon e Moisan, 1998).

Atualmente, com a utilização dos recursos de simulação em elementos finitos a compreensão do fenômeno da geração do cavaco tem sido mais investigada. Embora ainda não exista um modelo definitivo, vários modelos de plasticidade tem sido empregados como observa Guo et al (2006).

Umbrello et al (2007) executaram modelos em elementos finitos para geração do cavaco e temperaturas na condição de torneamento endurecido do aço AISI H13 na dureza de 500 HV (49 HRC). A Figura 50 (a) apresenta a malha de elementos finitos deformada para um cavaco cisalhado localmente que se apresenta idêntico a micrografia da seção do cavaco obtido na usinagem ortogonal experimental. $O$ ângulo de cisalhamento para esta condição foi de $50^{\circ}$ e as temperaturas na zona de cisalhamento atingiram valores entre 600 e $700^{\circ} \mathrm{C}$ como mostra a Figura 50 (b). 


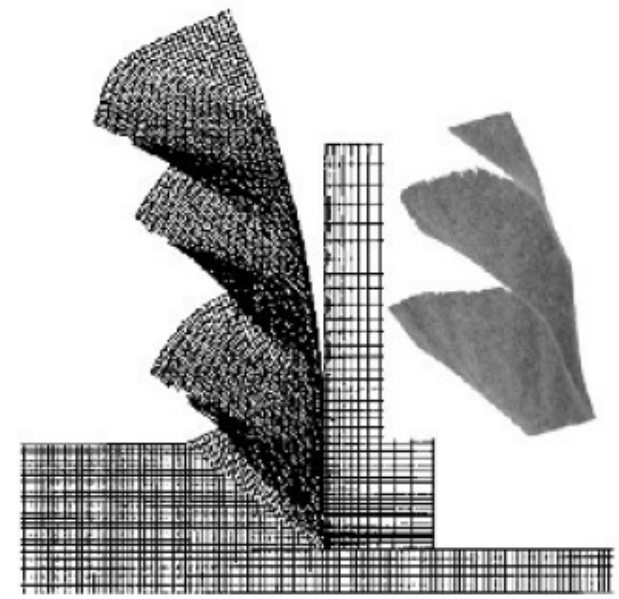

(a)

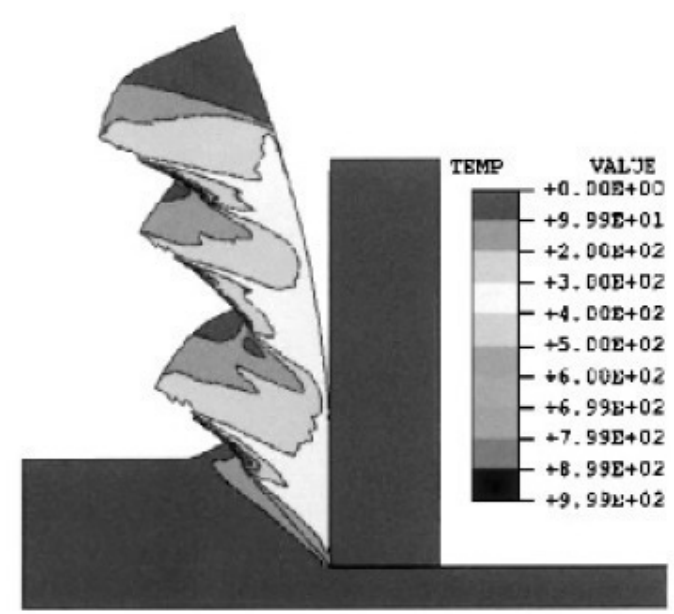

(b)

Figura 50. Modelo em elementos finitos da geração de cavacos e temperaturas. (a) Comparação com micrografia experimental, (b) valores de temperaturas. (Umbrello et al, 2007 e Oezel et al 2007).

Guo et al (2006) aplicaram modelos em elementos finitos para estudo do caso de torneamento de aço ABNT 52100 com dureza de 700 a 750 HV (60 a 62 HRC) com diferentes profundidades de corte. As Figuras 51 e 52 apresentam seus resultados comparados ao cavaco obtido experimentalmente nas diferentes condições de profundidade de corte.

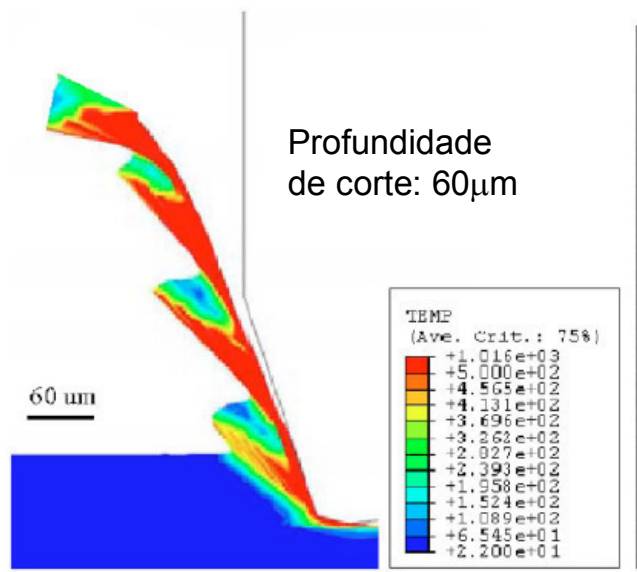

(a)

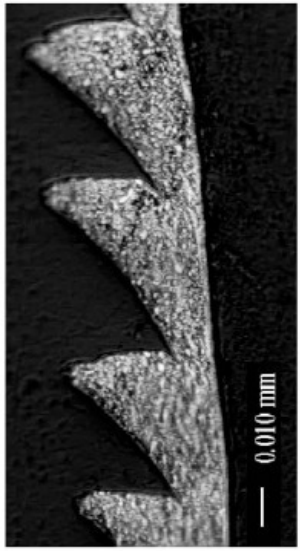

(b)

Figura 51. (a)Modelo em elementos finitos da geração de cavacos e temperaturas para profundidade de corte de 60 $\mathrm{mm}$. (b) Micrografia experimental. (Guo et al, 2006). 


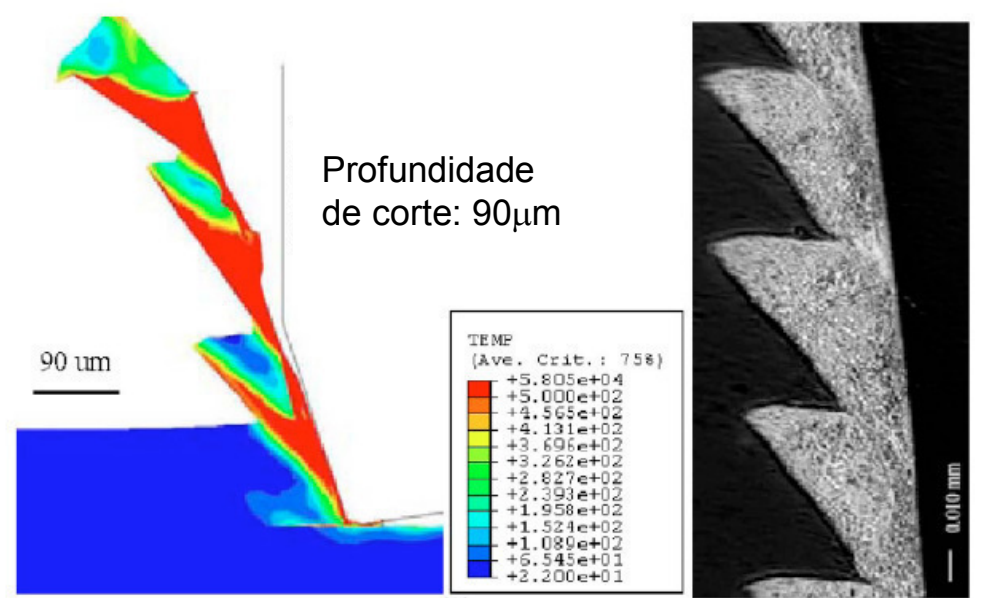

Figura 52. (a)Modelo em elementos finitos da geração de cavacos e temperaturas para profundidade de corte de $90 \mu \mathrm{m}$. (b) Micrografia experimental. (Guo et al, 2006).

\subsubsection{Material da Ferramenta em cBN}

O Nitreto de Boro cúbico (cBN) é um policristal produzido artificialmente, não sendo encontrado em forma natural. Possui propriedades únicas de grande dureza inclusive em elevadas temperaturas, abaixo somente do diamante. Segundo (Rech e Moisan, 2003 e Lin et al 2008) ferramentas em cBN provaram ser uma alternativa viável, provendo benefícios em redução de custos. Ferramentas em cBN mostram bom desempenho durante a usinagem de materiais endurecidos por causa de sua alta dureza, baixa solubilidade em ferro, e boa tenacidade à fratura tornando-se ideal para usinagem de materiais endurecidos e altamente abrasivos.

O policristal de cBN consiste de grãos selecionados e unidos com a utilização de ligas de cerâmicas (usualmente Nitreto de Titânio - TiN ou Carboneto de Titânio TiC) sinterizadas visando formar um material homogêneo e uniforme. As ligas de cerâmica, na composição do cBN, possuem uma função similar a do Cobalto, na manufatura do carboneto de Tungstênio, agindo como um ligante e unindo os grãos de cBN. O processo de manufatura do cBN começa com a sinterização do pó de Nitreto de Boro hexagonal (Figura 53) que é submetido a uma pressão de 75 Kbar e temperatura de $2000 \mathrm{~K}$, sendo assim convertido em finas partículas de Nitreto de Boro cúbico (cBN), Figura 54. Os grãos de cBN são então classificados pelo seu tamanho e classe a ser produzida, misturados ao elemento de liga formando um 
composto misto. O composto é sinterizado novamente sob elevada pressão e temperatura formando um disco que será processado posteriomente por retificação e lapidação para formar o inserto final.

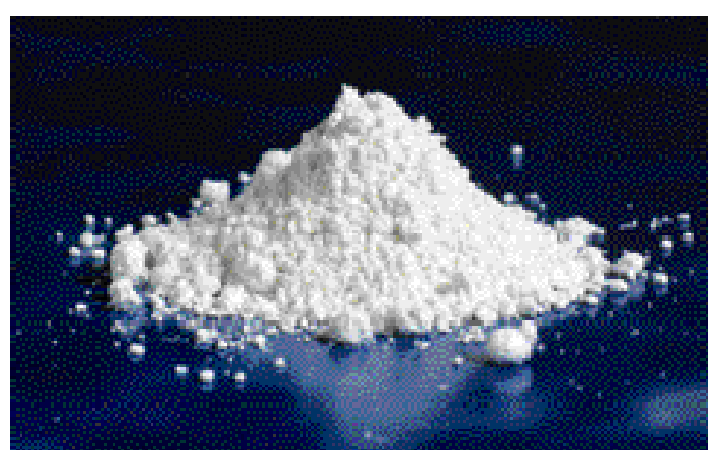

Figura 53. Pó de Nitreto de Boro hexagonal (Seco, 2003).

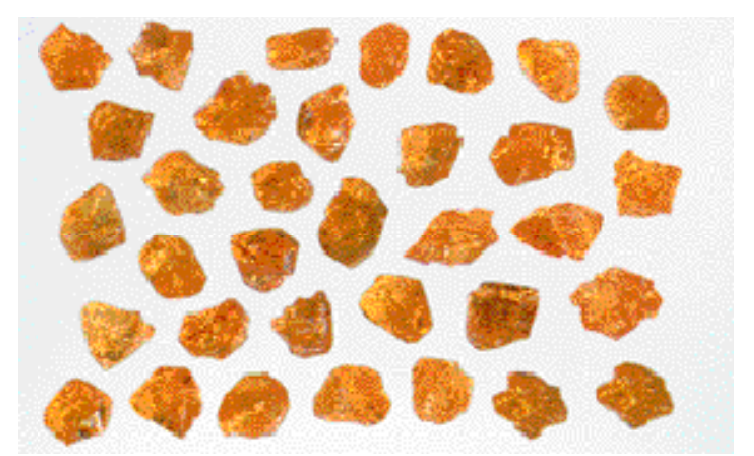

Figura 54. Grãos de cBN sinterizados (Seco, 2003).

O inserto final pode ter vários formatos e geralmente são encontrados como uma pequena peça (normalmente a ponta do inserto) brasada a um corpo de carboneto, este tipo reduz o custo total do inserto. Grzesik (2008) em seu livro apresenta os recentes avanços em fabricação de inserto de cBN, Figura 55.

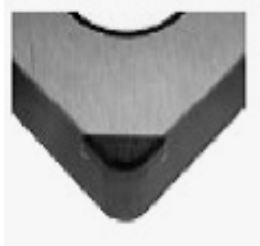

(a)

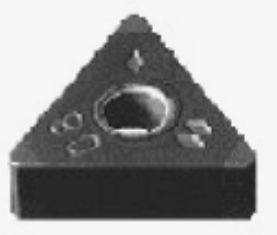

(b)

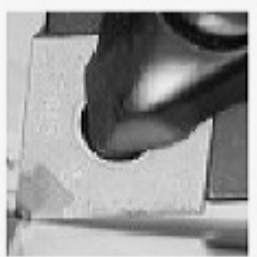

(c)

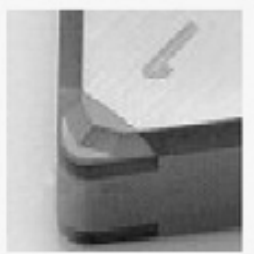

(d)

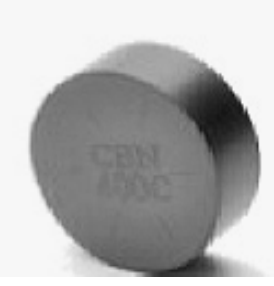

(e)

Figura 55. Exemplos de insertos $c B N$ : (a) $c B N$ ponta brasada diretamente no inserto de carboneto,(b) inserto multiplo, (c) inserto $C B N$ com trava de fixação mecânica e cantos sólidos brasados em posição afastada do contato cavaco-ponta, (d) inserto cBN com quebra-cavaco e (e) inserto de cBN sólido com cobertura total (TiC).(Grzesik, 2008a). 


\subsubsection{Propriedades da Ferramenta em cBN}

\subsubsection{Dureza}

Na escala relativa Mohs o diamante monocristalino é o material mais duro com o valor de 10. O óxido de alumínio tem o valor 9 e o monocristal de cBN situa-se entre estes dois valores. A dureza Knoop foi construida em função do grau de penetração de um material mole por outro mais duro. Um material com grande número Knoop é mais duro que o material com número menor. O diamante tem por volta de 69 GPa $\left(7000 \mathrm{~kg} / \mathrm{mm}^{2}\right)$ e o cBN fica em torno de $46 \mathrm{GPa}\left(4700 \mathrm{~kg} / \mathrm{mm}^{2}\right)$ (Gardinier, 1988, apud Costa, 1993). Entretanto, a dureza dos insertos de cBN policristalino são inferiores a do $\mathrm{cBN}$ monocristalino e varia conforme o conteúdo de $\mathrm{cBN}$ presente no inserto (Costa, 1993).

A Tabela 6 apresenta alguns exemplos de composições e propriedades segundo catálogo do fabricante de insertos Seco (2003).

Tabela 6. Tipos de cBN e suas características (Seco, 2003).

\begin{tabular}{|c|c|c|c|c|c|c|}
\hline Microestrutura & Produto & $\begin{array}{c}\text { Volume de } \\
\text { cBN } \\
\text { (\%aprox.) }\end{array}$ & $\begin{array}{c}\text { Tamanho } \\
\text { médio de } \\
\text { grão }[\mu \mathrm{m}]\end{array}$ & $\begin{array}{c}\text { Ligante } \\
\text { cerâmico }\end{array}$ & $\begin{array}{c}\text { Dureza } \\
\text { Knoop } \\
{[\mathbf{G P a}]}\end{array}$ & $\begin{array}{c}\text { Condutividade } \\
\text { Térmica a } \\
\mathbf{2 0}^{\circ} \mathbf{C} \\
{\left[\mathbf{W m}^{-1} \mathbf{K}^{-1}\right]}\end{array}$ \\
\hline CBN300 & 90 & 22 & $\mathrm{Al}$ & 30.4 & 130 \\
\hline & CBN20 & 80 & 6 & TiAl & 29.1 & 99 \\
\hline & CBN100 ${ }^{1}$ & 50 & 2 & TiC & 27.5 & 44 \\
\hline & CBN10 ${ }^{1}$ & 50 & 2 & TiC & 27.5 & 44 \\
\hline & CBN150 & 45 & $<1$ & TiN & 24.2 & 34 \\
\hline
\end{tabular}

Segundo Diniz e Oliveira (2008), ferramentas em cBN policristalino podem ser separadas basicamente em duas classes: alto conteúdo de cBN (por volta de $90 \%$ ) e baixo conteúdo de cBN (por volta de 60\%). Já Grzesik (2008a) indica que o cBN de baixo conteúdo possui valores entre 45 e $60 \%$ em volume.

\footnotetext{
${ }^{1} \mathrm{~A}$ diferença entre os dois insertos está no formato como é disponibilizado: CBN100 é uma pastilha inteira e CBN10 é uma ponta ou face brasada em um corpo de metal duro.
} 
A dureza a quente (aproximadamente $1000^{\circ} \mathrm{C}$ ) dos insertos de cBN policristalino é superior aos insertos cerâmicos comerciais, com podemos observar na Figura 56. Nessa figura ainda estão incluídas as curvas (dureza $x$ temperatura) para o diamante policristalino, o metal duro, ligas fundidas, aço rápido e aço ferramenta.

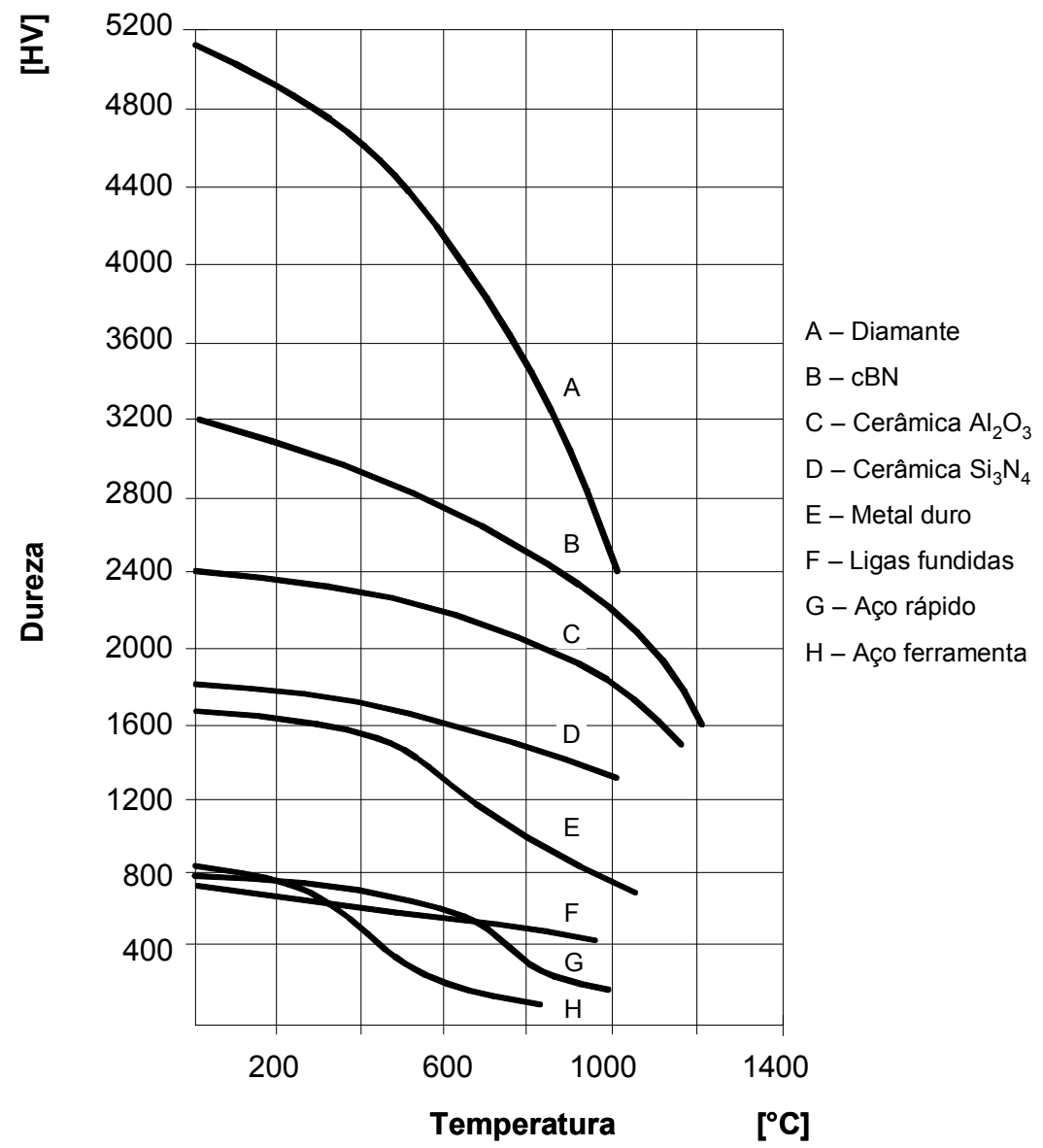

Figura 56. Variação da dureza com a temperatura para diferentes materiais de ferramenta (Boehs, 1987, apud Costa 1991).

\subsubsection{Resistência Mecânica}

Segundo Costa (1993) valores de tenacidade da ordem de $10 \mathrm{Mpa} \cdot \mathrm{m}^{1 / 2} \mathrm{bem}$ próximos ao metal duro e superiores às cerâmicas têm sido reportados para o insertos Borazon com alto teor de cBN (90 a 95\%). Borazon é o nome comercial do cBN policristalino fabricado pela General Eletric, e para esse teor de cBN, ele é sinterizado juntamente com um metal (cobalto).

Baseando-se em sua propriedade de condutividade térmica (Tabela 6) pode-se dizer que a resistência ao choque térmico de materiais com maior teor de CBN é 
consideravelmente alta. Porém, para insertos com alto teor de cerâmica (TiC ou TiN) como segunda fase, espera-se uma resistência inferior. Pois a condutividade térmica desses últimos é bem inferior a dos primeiros.

\subsubsection{Resistência a Reações Químicas}

As propriedades mecânicas e térmicas do diamante policristalino são bem superiores as do $\mathrm{cBN}$ policristalino. Entretanto, quando se trata da usinagem de materiais ferrosos, devido a alta temperatura envolvida, o diamante reage com 0 ferro tornando inviável sua aplicação na usinagem de tais materiais. Por sua vez o cBN não reage com o ferro. O Nitreto de Boro presente no cBN reage com o oxigênio em altas temperaturas formando o óxido de boro, uma película protetora impedindo o prosseguimento da reação (Gardinier, 1988, apud Costa, 1993).

\subsubsection{Desgaste de Ferramenta}

Basicamente estudam-se dois modos de desgaste de ferramenta quando tratamos de usinagem em material endurecido devido as condições impostas de temperatura e dureza do material. O desgaste de flanco (VB, Figura 57-a) que é o desgaste que surge na ferramenta causada pelo atrito da face de folga da ferramenta contra a superfície usinada, região da zona terciária (Figura 38). E o desgaste de cratera (Figura 57-b) que é o desgaste que surge na ferramenta causada pelo atrito da face inferior do cavaco que sai contra a face de saída da ferramenta, região da zona secundária (Figura 38).

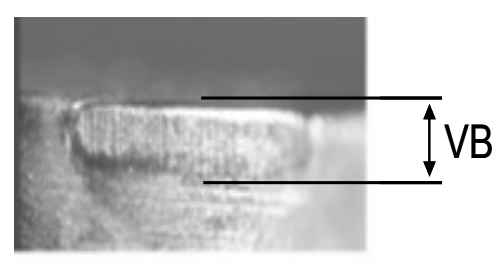

(a)

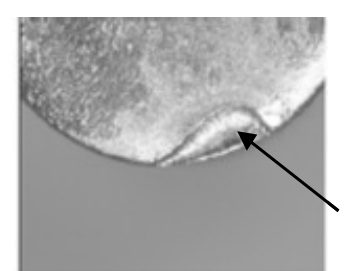

Desgaste de Cratera

Figura 57. Modos de desgaste de ferramenta (a) Desgaste de flanco (VB), (b) desgaste de cratera (Poulachon et al, 2001). 
A Figura 58 apresenta o mapa de mecanismos de desgaste de ferramenta em função da velocidade de corte e avanço. Podemos observar que condições muito altas ou muito baixas provocam desgaste na ferramenta de corte. Ao selecionar dados de corte existe uma faixa chamada Zona Segura, onde o par velocidade de corte $\left(V_{c}\right)$ e avanço $(f)$ nesta região tende a provocar o modo de desgaste plástico (uniforme e controlado).

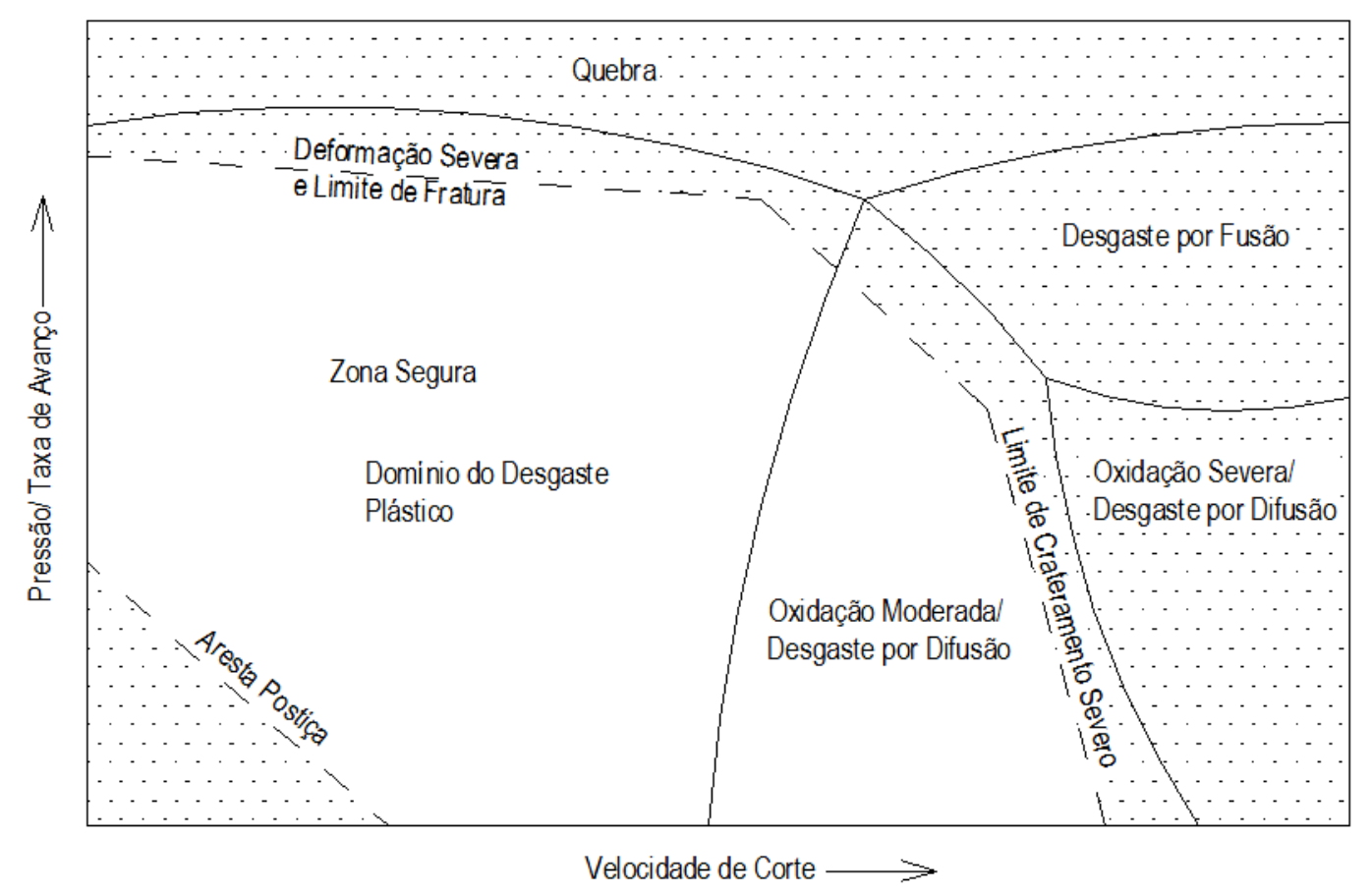

Figura 58. Modos de falha da ferramenta em funçao da condição de usinagem (ASM Handbook v18, 1991).

Poulachon et al (2001), analisou modos de desgaste de ferramentas com diversas condições de corte. A Figura 21, apresentada no capítulo 2.1.8, mostra o comportamento do desgaste da ferramenta em função do tempo na usinagem de aço ABNT 52100 endurecido com 700HV. Podemos observar três regiões distintas: Desgaste Inicial, desgaste controlado (ou plástico) e falha da ferramenta. 


\subsection{Rugosidade Superficial em Três Dimensões}

A superfície de um sólido é a parte que representa a fronteira entre o corpo sólido e seu ambiente. Superfícies como entidades físicas possuem muitos atributos, a geometria é um deles. A geometria de uma superfície é tridimensional por natureza, e as características são denominadas de topografia.

$\mathrm{Na}$ prática, a noção de uma superfície estende-se à subcamadas além da fronteira externa e a superfície interna assume certas características. Estas características internas, por exemplo, dureza, tensão residual, composição química mais suas reações e microestrutura, muitas vezes referem-se ao desempenho funcional da superfície. Portanto, a topografia da superfície é importante para o desempenho superfície, e a importância da medição da superfície como um meio de análise funcional é incontestável (Stout et al, 1993).

A modificação da topografia da superfície é realizada por remoção de material, tratamento térmico ou adição de coberturas. Na maioria das vezes uma combinação de várias usinagens, tratamento térmico e operações de revestimento são utilizadas para produzir superfícies com as características que são desejáveis para uma determinada aplicação.

Grzesik et al (2006), estudaram os resultados da combinação de dois processos de usinagem, torneamento em material endurecido com posterior polimento com cinta de lixa. A Figura 59 apresenta a medição topográfica de uma superfície fabricada.

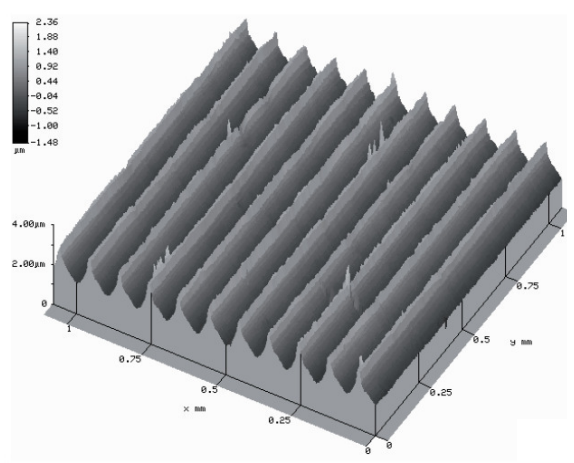

(a)

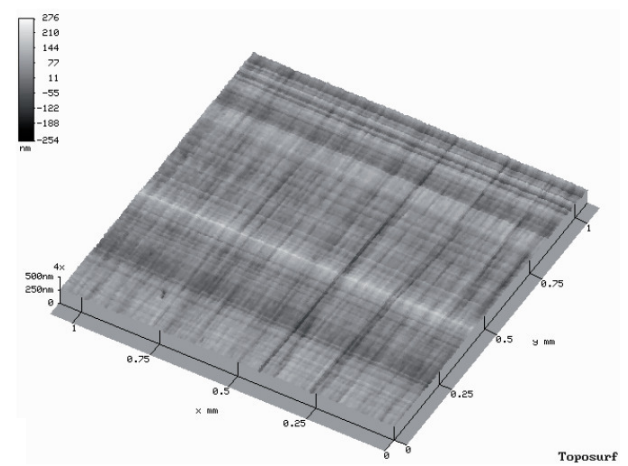

(b)

Figura 59. Topografia da superfície (a) torneada e (b) polida (Grzesik et al, 2006). 
A topografia da superfície contém assinaturas do processo da geração de superfície e, como tal, pode ser utilizado para diagnosticar, acompanhar e controlar o processo de fabricação. A não observação de que cada processo cria uma superfície distinta pode colocar em risco todo o desempenho funcional de uma peça (Whitehouse, 1982).

Segundo Stout et al (1993), o objetivo final da medição topográfica da superfície como um meio de controle e conhecimento, é estabelecer uma correspondência entre um fenômeno de superfície de engenharia como, por exemplo, desgaste e vibração, e as suas características topográficas (área de carregamento, volume de retenção de óleo e ondulações). O relacionamento entre o projeto da superfície, a função, a fabricação e avaliação são mostrados esquematicamente na Figura 60.

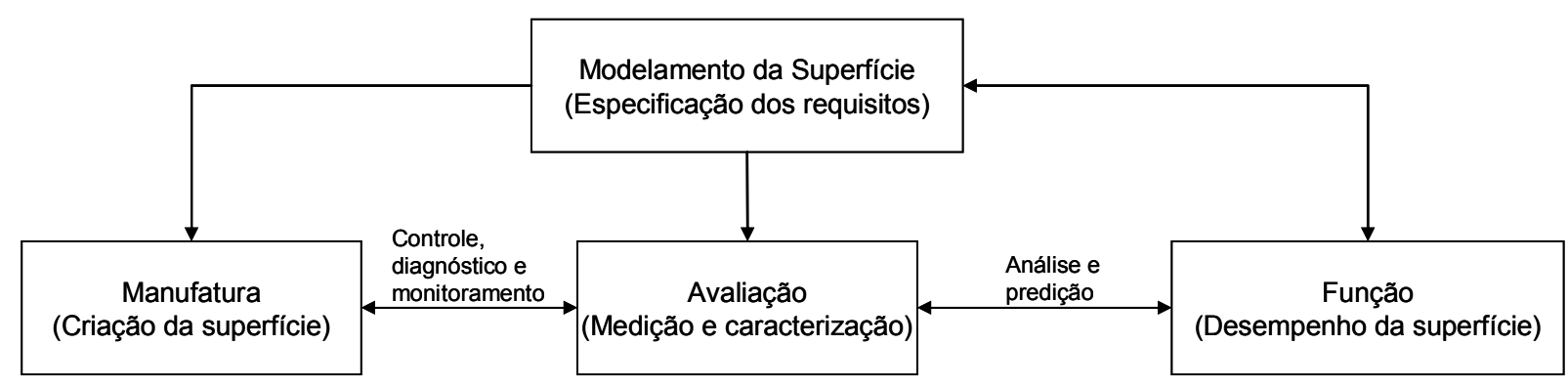

Figura 60. Relações entre um modelamento de superfície (Stout et al, 1993).

As superfícies são por natureza entidades físicas em três dimensões (3-D) e, por conseguinte, os fenômenos de superfície relacionados ocorrem em três dimensões (Griffiths, 2001). Por exemplo, a interação entre duas superfícies em contato realiza-se no âmbito de toda a interface (a interação entre uma superfície áspera e o fluxo de um fluido também ocorre tri-dimensionalmente).

Portanto, a descrição e análise de superfícies baseado em medição 3-D representa uma abordagem mais realista e eficaz para a compreensão de fenômenos superficiais. Um procedimento geral de ciclo de medição de superfície topográfica é mostrado na Figura 61. Fornecidos os requisitos e especificações de 
medição, um típico processo de medição inclui os seguintes passos: aquisição dos dados, pré-processamento e caracterização (Stout et al, 1993).

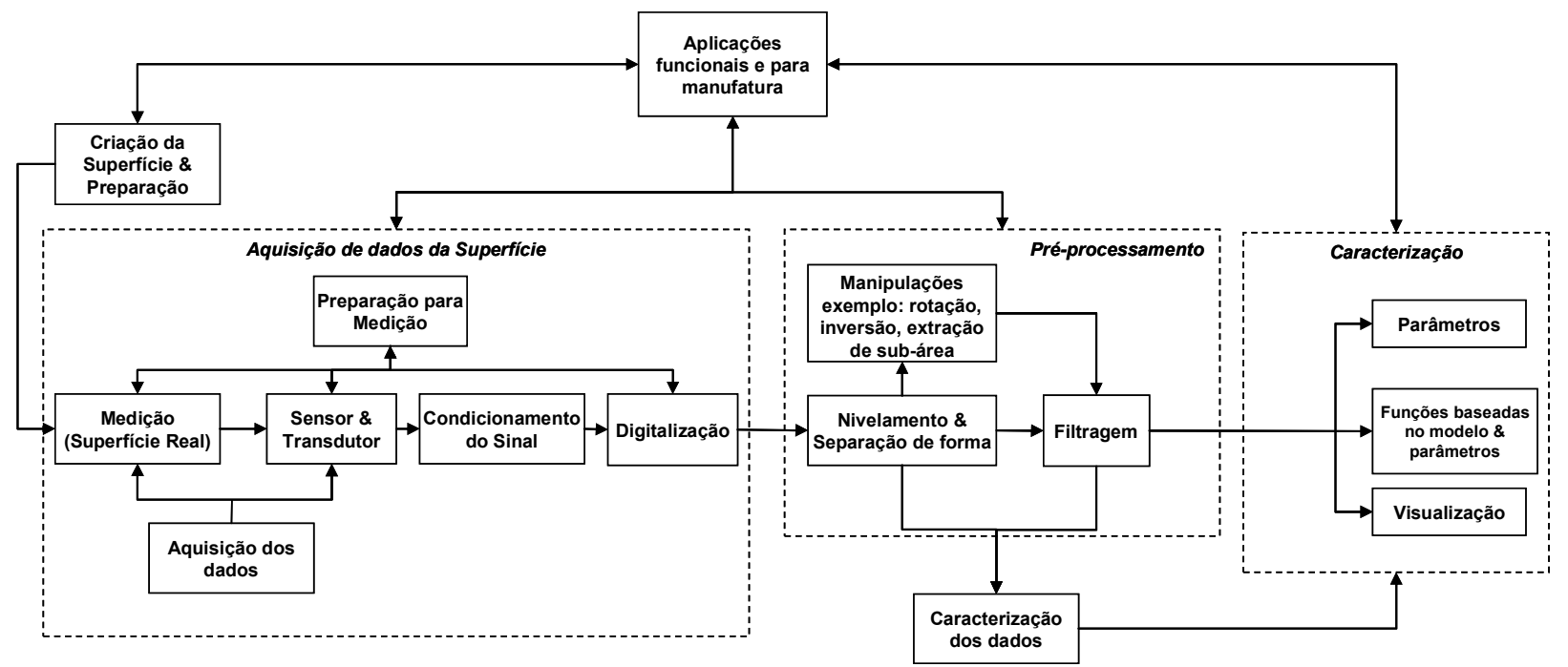

Figura 61. Procedimento geral para avaliação de topografia superficial 3-D (Stout et al, 1993).

Medição de superfície 3-D invariavelmente envolve o uso de computadores, devido à grande quantidade de informação envolvida. Os computadores estão envolvidos em diversas fases no processo de medição: controle da coleta de dados, armazenamento de dados, processamento, análise e saída de resultados. Em um sistema de coordenadas euclidiano, uma superfície física pode ser representada como uma função contínua $z(x, y)$, com duas variáveis independentes, $x$ e y, como mostrado na Figura 62.

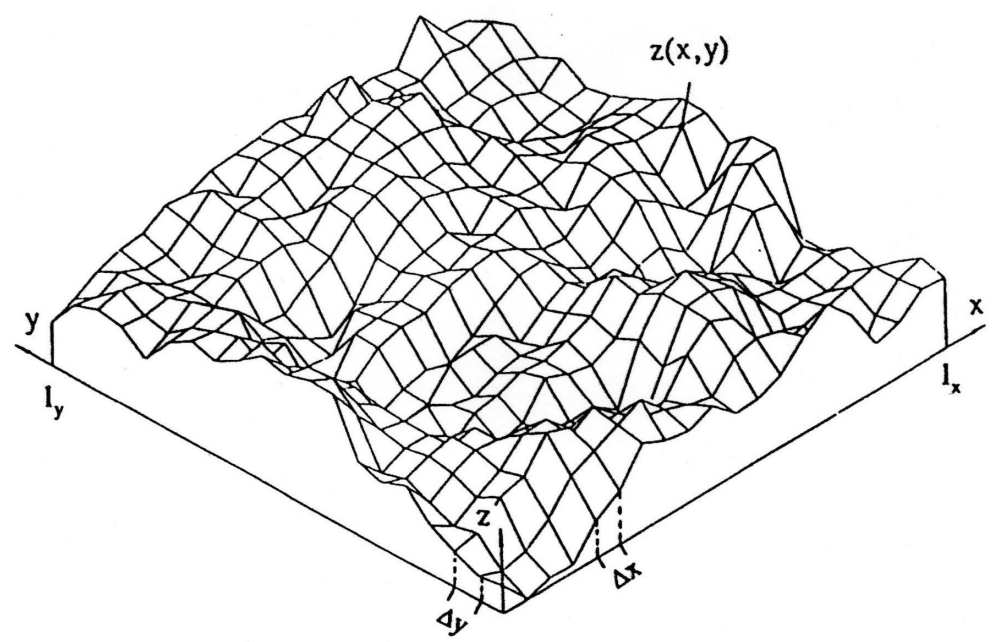

Figura 62. Sistema de coordenadas para representação de topografia superficial (Stout et al, 1993). 


\subsubsection{Aquisição dos Dados}

Sistemas de medição e aquisição de dados para topografia de superfícies 3-D são frequentemente classificados pelo princípio físico utilizado na interface superfície-sensor. Stout et al (1993), apresentaram um sistema de classificação baseado pelo princípio físico na Figura 63.

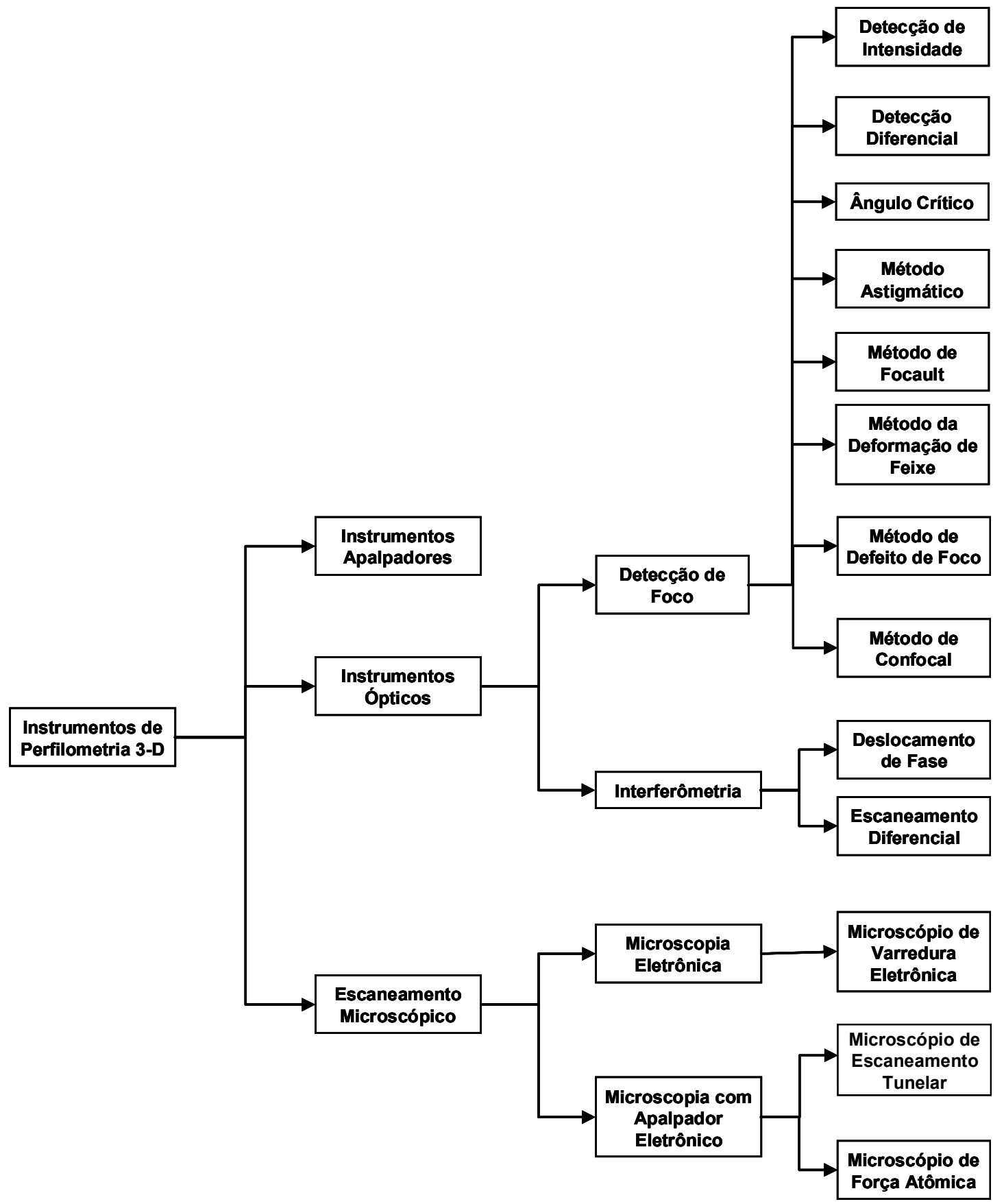

Figura 63. Classificação de instrumentos de medição topográfica baseados em seu princípio de aquisição de dados (Stout et al, 1993). 
Além do princípio de sensoriamento da superfície, informações relativas à suas respectivas capacidades como tamanho de área de medição, resolução, adequação quanto à aplicação, precisão nos dados e estratégia de digitalização são uma grande preocupação em sistemas de aquisição de dados de superfície 3-D.

As Figuras 64 a 66 apresentam alguns instrumentos comercialmente utilizados para aquisição de dados topográficos de superfícies tridimensionais.

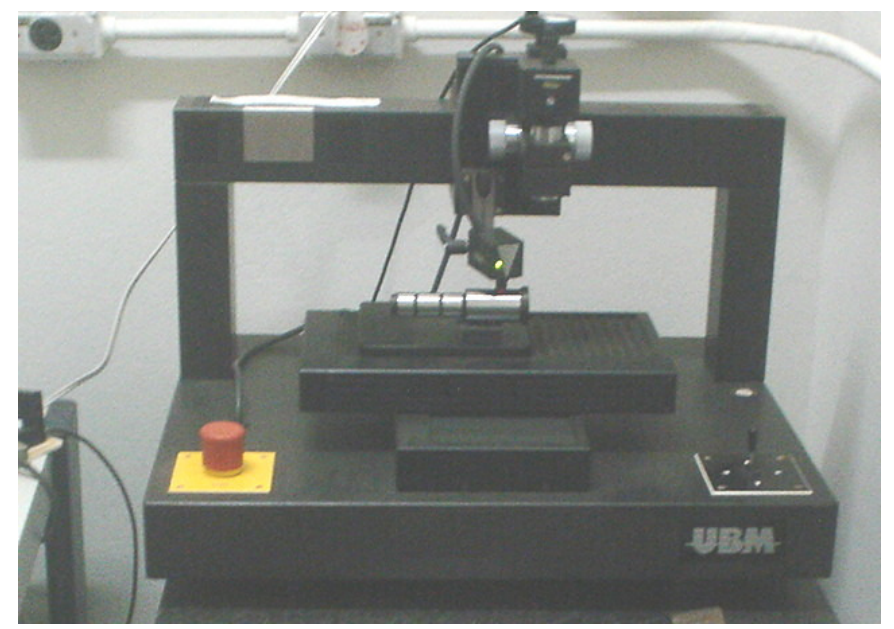

Figura 64. Interferômetro a laser (Microfocus Expert IV, UBM Corporation, Sunnyvale, CA, USA).
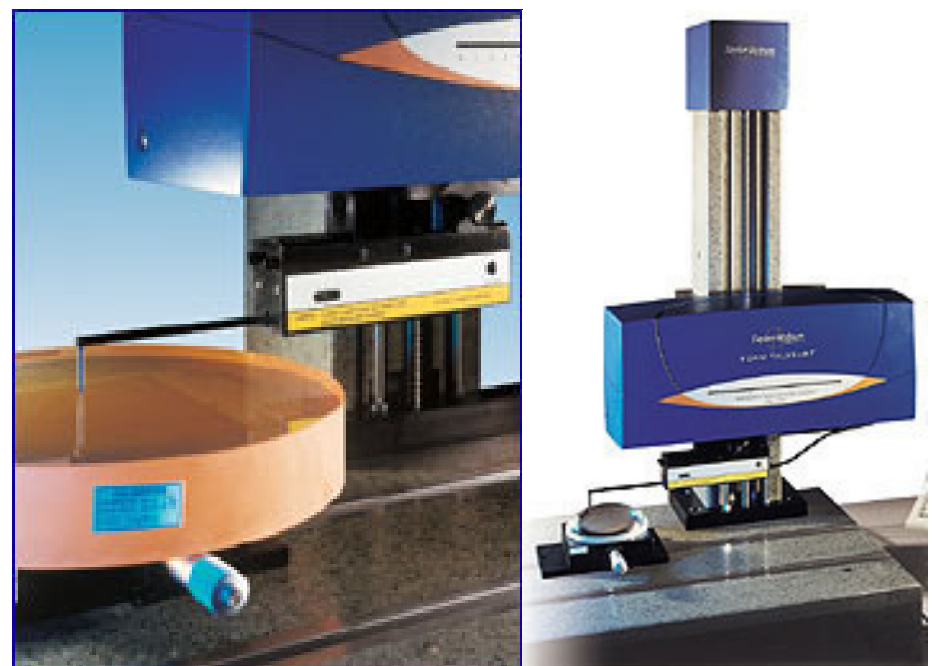

Figura 65. Perfilômetro apalpador (Form Talysurf PGI 1240, Taylor Hobson Ltd-subsidiary of AMETEK Inc, Paoli, Pennsylvania, USA). 


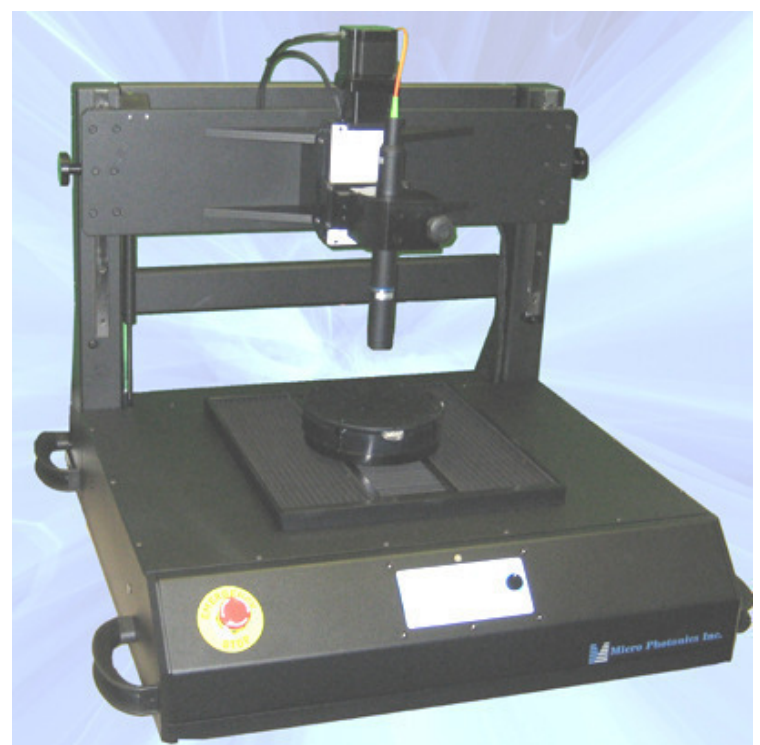

Figura 66. Perfilômetro de câmera (Nanovea ST400, Micro Photonics Inc., Irvine, CA, EUA).

\subsubsection{Pré-processamento}

Após o armazenamento dos dados coletados, algumas operações de aperfeiçoamento podem ser realizadas antes de uma análise mais aprofundada. Referindo-se à Figura 61, o pré-tratamento inclui: nivelamento da superfície de dados, remoção de forma, manipulações de dados (truncamento, rotação, inversão e extração de sub-área) se necessário e filtragem.

Nivelamento de superfície refere-se à remoção de tendência linear dos dados da superfície registrados devido ao desalinhamento da superfície nominal plana em relação à digitalização dos dados. Além disso, diferentes convenções de truncamento podem ser utilizados na codificação das alturas de superfície.

Remoção de forma é necessária quando a superfície é curva e a curvatura não participa no fenômeno da superfície.

Nivelamento e remoção de forma são frequentemente realizadas por métodos de mínimos quadrados e podem ser realizados em um único processo.

Filtragem refere-se à separação dos diferentes componentes de frequência na superfície dados. Um filtro de superfície deve ter fase zero ou linear e uma boa função de ponderação. Estas duas propriedades de um filtro de superfície irá ajudar a preservar as características gerais da superfície. Um filtro Gaussiano satisfaz 
ambos os critérios e pode ser convenientemente modelado. A princípio, em primeira instância, a utilização de filtragem é por motivo funcional. A utilização de filtros é particularmente censurável quando o significado funcional dos diferentes componentes da frequência da rugosidade não é clara (Stout et al, 1993). Estas operações de pré-tratamento visam transformar os dados coletados em base para posterior caracterização.

\subsubsection{Caracterização}

A grandeza Topografia Superfícial é de complexa representação, ao contrário de outras grandezas como comprimento, temperatura e força, sua representação numérica é dificultosa. Representação por parâmetro é invariavelmente obtida por fundamentos estatísticos e só é eficaz do ponto de vista de engenharia quando a informação reflete o princípio do significado funcional, ou seja, a representação do fenômeno de engenharia da superfície.

Representações além da numérica tendem a ser mais estruturais, na medida em que geram informações para interpretação humana ou de máquina, e, também fornecer estruturas numéricas que correspondem de forma mais eficaz com a topografia e características da superfície em questão (Stout et al, 1993).

\subsubsection{Procedimentos de Amostragem}

Na medição em 3-D de uma superfície cilíndrica ou plana, um determinado número de perfis paralelos ao eixo principal da amostra deve ser recolhido. $O$ deslocamento sobre a superfície é executado em duas direções ortogonais: $X$ e $Y$. $\mathrm{Na}$ direção $X$ os dados são recolhidos com um passo (intervalo) de amostragem $\Delta \mathrm{x}$ e um determinado número de pontos $\mathrm{Nx}$, na direção $\mathrm{Y}$ as linhas são em um passo (intervalo) de amostragem $\Delta y$ e existem Ny linhas. Os dados são armazenados em disco na forma de um arquivo binário. Quando o procedimento de coleta de pontos 
(sensoreamento da superfície) está finalizado, uma matriz que representa a superfície constituída por Nx*Ny pontos, é obtida.

O número de pontos e sua separação influenciam vários fatores importantes como, gama de frequências que podem ser identificadas, resolução e o tempo de coleta destes pontos.

\subsection{5 Área de Amostragem e Área de Avaliação}

Em medições 2-D alguns termos são de extrema importância como, por exemplo: "cut-off", comprimento de amostragem e comprimento de avaliação. O cutoff determina as características dos filtros eletrônicos (geralmente filtros de frequência alta) dos instrumentos de medição topográfica. O comprimento de amostragem é o comprimento físico de um perfil estudado. Os valores destes dois parâmetros são iguais.

A fim de aumentar a confiabilidade estatística dos parâmetros de estimação em 2-D, são definidos um ou mais (geralmente 5) comprimentos de amostragem dentro de um comprimento de avaliação, que usualmente são perfís consecutivos e independentes nas estatísticas. Fisicamente, existem duas diferenças entre uma área mapeada em 3-D e perfis mapeados em 2-D:

A área mapeada contém perfis paralelos que normalmente são obtidos em digitalização por varredura, e as relações entre estes perfis paralelos devem ser mantidas.

Por causa da segunda diferença, os filtros eletrônicos tradicionais utilizados durante o processo de digitalização que filtram a frequência baixa não devem ser utilizados em medição topográfica 3-D. Caso contrário, a informação espacial de baixa freqüência, que constrói a relação entre os perfis iria desaparecer. Portanto, o conceito tradicional de cut-off, definida em normas 2-D, não podem ser impostas em medição 3-D. A frequência dos componentes envolvidos em uma superfície mapeada deve ser determinada pelas características dos instrumentos utilizados, em vez de serem especificados durante a digitalização. Em uma medição 3-D a filtragem 
digital deve ser aplicada, sempre que necessário, depois de toda digitalização da área em questão.

Segundo Stout et al (1993), parâmetros 2-D são avaliados no âmbito de comprimento de avaliação, em vez do comprimento de amostragem. Para avaliação 3-D, o comprimento de amostragem e comprimento de avaliação é promovido para a área de amostragem e área de avaliação. A inter-relação entre a área de amostragem e de avaliação está ligada à independência dos perfis ou Motivos ${ }^{2}$ isto é, se mais perfis independentes estão contidos em uma área mapeada do que aqueles contidos em uma área de avaliação. O tempo de aquisição dos dados (tempo que leva a digitalização de uma superfície) define se os parâmetros 3-D devem ser obtidos pela média das várias áreas de amostragem.

A Figura 67 apresenta duas superfícies digitalizadas de um mesmo material com áreas diferentes $\left(5 \mathrm{~mm}^{2}\right.$ e $\left.0.5 \mathrm{~mm}^{2}\right)$ onde são extraídos seus parâmetros de rugosidade. Nota-se que quanto maior a área da superficie analisada maior a quantidade de perfís ou motivos que se repetem, mais detalhes serão levados em consideração no cálculo dos parâmetros, porém comparando-se os resultados de ambas superfícies quanto aos parâmetros relacionados à distribuição média de altura $\left(S_{a}, S_{q}\right)$ nota-se pouca ou despresível variação. O contrário se verifica com os parâmetros de forma da distribuição $\left(S_{\mathrm{sk}}, S_{\mathrm{ku}}\right)$ onde se verifica uma influência do maior número de motivos (independentes) encontrados na superfície de área maior $5 \mathrm{~mm}^{2}$.

O tempo de medição da superfície (digitalização dos dados) é dependente do instrumento de medição utilizado. Interferômetros ópticos, microscópios de varredura tunelar e microscópios de força atômica, são suficientemente rápidos para mapear uma área de 256x256 pontos em segundos. Porém, outros instrumentos de medição comumente usados em aplicações de engenharia, ópticos ou mecânicos, podem levar vários minutos ou horas para mapear uma área que inclui o mesmo número de pontos. Se uma área de avaliação contém várias áreas de amostragem, o tempo para digitalização dos dados usando instrumentos lentos é intolerável nas aplicações práticas.

\footnotetext{
${ }^{2}$ Biasoli de Mello, J. D., UFU-MG, 2007: Termo utilizado para caracterizar formas geométricas (independentes ou não) encontradas ao longo de uma superfície digitalizada.
} 


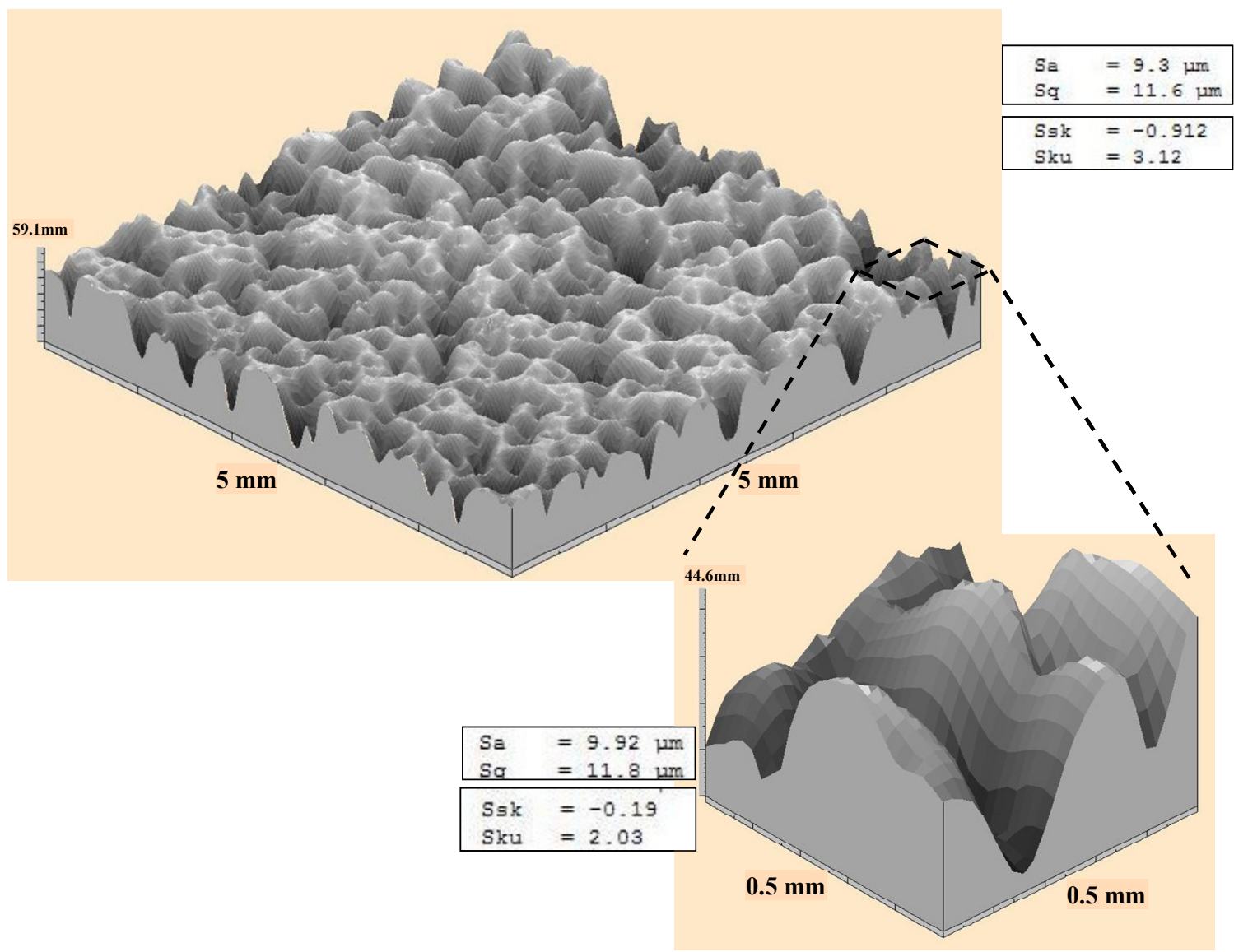

Figura 67. Análise de rugosidades com diferentes áreas de avaliação de uma mesma superfície (Mountains Map, Digital Surf Sarl, Bensancon, França).

\subsubsection{Parâmetros de Caracterização da Topografia Superficial 3-D}

\subsubsection{Parâmetros de Amplitude}

Dois parâmetros básicos utilizados por muitos pesquisadores (Stout et al, 1993) são os parâmetros de dispersão:

$\mathbf{S}_{\mathrm{a}}$ : Desvio Médio Aritmético da Superfície, que é definido como sendo a média aritmética dos valores absolutos dos picos e vales da superfície partindo de um plano médio dentro de uma área de amostragem. 
$\mathbf{S}_{\mathbf{q}}$ : Desvio Médio Quadrático da Superfície é definido como sendo a média quadrática dos valores absolutos dos picos e vales da superfície partindo de um plano médio dentro de uma área de amostragem.

\subsubsection{Parâmetros Funcionais}

A busca de valores que indiquem a capacidade funcional da superfície não deve se restringir a poucos parâmetros, como por exemplo, Desvio Médio Aritmético da Superfície $\left(\mathbf{S}_{\mathrm{a}}\right)$ e Desvio Médio Quadrático da Superfície $\left(\mathbf{S}_{\mathbf{q}}\right)$, pois segundo Waicar e Guo, (2008), ambos possuem forte correlação e apesar de seu uso geral carecem de significado funcional, apresentando apenas significado estatístico. Devese buscar todo um conjunto de informações que indiquem com segurança a condição atual da superfície. A Tabela 7 apresenta o significado funcional dos parâmetros de rugosidade segundo Stout et al (1993) e Griffiths (2001). Ainda hoje, a normalização de determinados parâmetros de rugosidade não está totalmente definida, especialmente rugosidade em medições 3-D, sendo ainda motivo de controvérsia entre pesquisadores. A tabela abaixo apresenta os parâmetros mais recorrentes em artigos e estudos.

Tabela 7. Significado funcional dos parâmetros de rugosidade (Stout et al, 1993).

\begin{tabular}{|c|c|c|}
\hline & \multicolumn{2}{|c|}{ Parâmetros } \\
\hline & $\mathrm{S}_{\mathrm{sk}}, \mathrm{S}_{\mathrm{ku}}$ & $S_{p k}, S_{k}, S_{v k}$ \\
\hline $\begin{array}{l}\text { Característica do } \\
\text { parâmetro } \Rightarrow\end{array}$ & $\begin{array}{l}\text { Forma da } \\
\text { distribuição }\end{array}$ & Funcionais \\
\hline Função 』 & & \\
\hline Capacidade de carga & O & 0 \\
\hline Vedação & 0 & 0 \\
\hline Atrito & $\mathbf{0}$ & 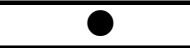 \\
\hline Rigidez em junções & 0 & 0 \\
\hline Deslizamento & O & 0 \\
\hline Contatos elétricos/térmicos & 0 & 0 \\
\hline Desgaste & 0 & 0 \\
\hline Adesão & 0 & 0 \\
\hline Pintura & $\bar{D}$ & 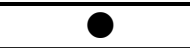 \\
\hline Conformação & $\mathbf{D}$ & 0 \\
\hline Fadiga & D & 0 \\
\hline Tensão \& Fratura & $\mathrm{O}$ & 0 \\
\hline Refletividade & $\mathrm{O}$ & 0 \\
\hline Higiene & $\bar{D}$ & 0 \\
\hline
\end{tabular}

\begin{tabular}{|l|l|}
\hline \multirow{3}{*}{ Legenda: } & $\bullet:$ Forte Influência \\
\cline { 2 - 2 } & D: Pouca Influência \\
\cline { 2 - 2 } & O:Possível Influência \\
\hline
\end{tabular}


A seguir a descrição dos parâmetros mencionados na Tabela 7:

$\mathbf{S}_{\mathbf{s k}}$ : Assimetria da Distribuição das Alturas da Topografia é definida como a assimetria dos desvios da superfície sobre o plano médio, Figura 68. Este parâmetro descreve efetivamente 0 formato da distribuição das alturas da topografia. Para uma superfície com distribuição Gaussiana, que possui simetria de distribuição, o parâmetro $S_{\text {sk }}$ é igual a zero. Para uma distribuição assimétrica das alturas, seu valor pode ser negativo indicando a existência de mais vales ou positivo indicando existência de mais picos. Um valor negativo na Assimetria da Distribuição das Alturas da Topografia $S_{\text {sk }}$ indica uma melhor condição de retenção de fluidos e melhor capacidade de carregamento, portanto melhor desempenho.

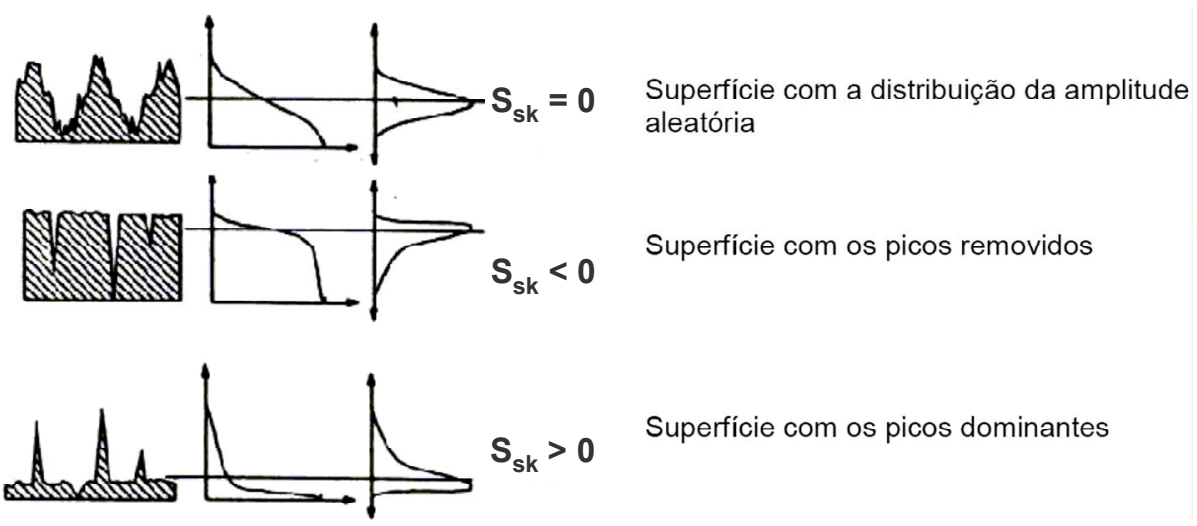

Figura 68. Classificação de valores para Assimetria da Distribuição das Alturas (Freitas, 2006).

$\mathbf{S}_{\mathrm{ku}}$ : Curtose da Distribuição das Alturas da Topografia é a medida do grau de afinamento ou achatamento da distribuição dos picos de alturas Figura 69. Uma superfície com distribuição Gaussiana, caracterizada por sua simetria, o parâmetro $S_{k u}$ é igual a três, para acumulo de alturas na localização central da distribuição seu valor é maior do que três e para alturas largamente espalhadas na distribuição o valor é menor do que três. Valores superiores a três na Curtose indicam superfícies com picos mais finos, mais susceptíveis ao desgaste prematuro, e valores inferiores a três indicam superfícies com menor tendência ao desgaste prematuro. 

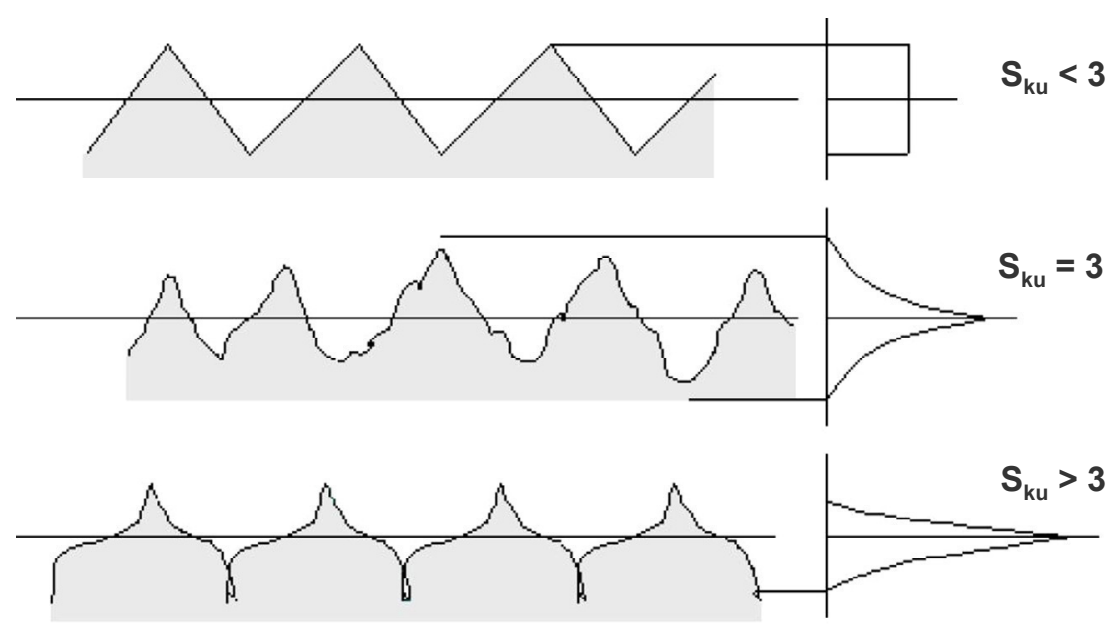

Figura 69. Classificação de valores para Curtose da Distribuição das Alturas (Freitas, 2006).

\subsubsection{Parâmetros Funcionais da Distribuição das Alturas Baseados na Curva da Área de Carregamento}

A norma ISO 13565-2 (1996) define cinco parâmetros baseados na Curva da Área de Carregamento ou Curva Abbott-Firestone, onde estes parâmetros expressam a composição da distribuição dos picos e vales na superfície. A Figura 70 apresenta a divisão das áreas na Curva da Área de Carregamento e o método para extração dos parâmetros, baseados na plotagem de uma linha que abrange $40 \%$ da fração do material central da curva.

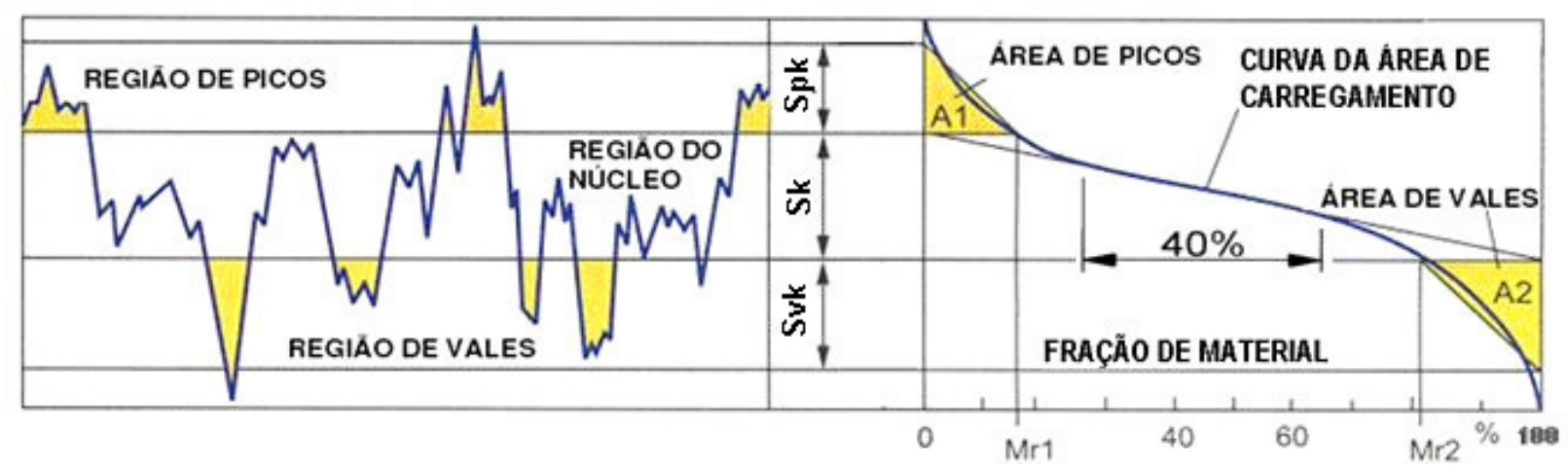

Figura 70. Distribuição de picos e vales e Parâmetros Funcionais Baseados na curva de AbbottFirestone ou Curva da Área de Carregamento (Mummery, 1992). 
$\mathbf{S}_{\mathbf{p k}}$ : Altura Reduzida do Pico e é definida na norma ISO 13565-2 (1996) como a altura média dos picos acima do perfil da rugosidade do núcleo. Ela representa a porção da superfície que sofrerá desgaste prematuro. Processos que produzam baixos valores para este parâmetro são ideais para onde a geometria do produto deva ser mantida após o início de operação do componente.

$\mathbf{S}_{\mathbf{k}}$ : Profundidade da Rugosidade do Núcleo e é definida na norma ISO 13565-2 (1996) como a profundidade da rugosidade do núcleo do perfil. Ela caracteriza o desgaste em longo prazo da superfície, que vai influenciar o desempenho operacional da superfície. Valores baixos para este parâmetro indicam maior capacidade de carga durante operações de contato.

$\mathbf{S}_{\mathbf{v k}}$ : Profundidade reduzida do Vale e é definida na norma ISO 13565-2 (1996) como a profundidade média do perfil dos vales projetados além do perfil da rugosidade do núcleo. Ele caracteriza a capacidade de retenção de fluidos dos vales da superfície. Valores altos indicam maior capacidade de retenção de fluidos lubrificantes.

$\mathbf{M}_{\mathrm{r} 1}$ e $\mathbf{M}_{\mathbf{r} 2}$ : Porções do Material da Superfície: definidas na norma ISO 13565-2 (1996) como a porção do material determinado pela intersecção da linha que separa as alturas dos picos do perfil da rugosidade do núcleo e a porção do material determinado pela intersecção da linha que separa o perfil dos vales projetados além do perfil da rugosidade do núcleo. Com estes dois parâmetros indicam-se a porcentagem de superfície que se encontra na área de picos, área do núcleo e na área de vales.

Segundo Stout et al (1993), a importância da medição da superfície como um meio de análise funcional é incontestável. Deve-se associar a superfície uma grandeza funcional e não somente um valor numérico.

Whitehouse (1982), conclui em seu artigo que medições de rugosidade devem ser executadas de forma cautelosa, pois a funcionalidade de uma superfície está atrelada ao seu processo de fabricação. Interpretações baseadas em valores de parâmetros podem muitas vezes levar a enganos. Uma mudança de processo pode não causar grandes alterações em um determinado parâmetro, mas pode afetar 
fortemente outros parâmetros funcionais que irão causar a perda de desempenho ou rendimento quando a superfície for posta em trabalho.

De acordo com as descrições de cada parâmetro, a Tabela 8 apresenta uma síntese dos valores ótimos para sua melhor condição funcional.

Tabela 8. Referência funcional dos parâmetros de rugosidade.

\begin{tabular}{|l|l|c|}
\cline { 2 - 3 } \multicolumn{1}{c|}{} & \multicolumn{1}{|c|}{ Descrição do Parâmetro } & $\begin{array}{c}\text { Referência Funcional } \\
\text { para melhor condição }\end{array}$ \\
\hline $\mathbf{S}_{\mathrm{a}}[\mu \mathrm{m}]$ & Desvio Médio Aritmético da Superfície & - \\
\hline $\mathbf{S}_{\mathrm{q}}[\mu \mathrm{m}]$ & $\begin{array}{l}\text { Desvio Médio Quadrático da } \\
\text { Superfície }\end{array}$ & - \\
\hline $\mathbf{S}_{\mathbf{s k}}$ & $\begin{array}{l}\text { Assimetria da Distribuição das Alturas } \\
\text { da Topografia }\end{array}$ & Valor $<0$ \\
\hline $\mathbf{S}_{\mathbf{k u}}$ & $\begin{array}{l}\text { Curtose da Distribuição das Alturas da } \\
\text { Topografia }\end{array}$ & Valor $<3$ \\
\hline $\mathbf{S}_{\mathbf{p k}}[\mu \mathrm{m}]$ & Altura Reduzida do Pico & Valores Baixos \\
\hline $\mathbf{S}_{\mathbf{k}}[\mu \mathrm{m}]$ & $\begin{array}{l}\text { Profundidade da Rugosidade do } \\
\text { Núcleo }\end{array}$ & Valores Baixos \\
\hline $\mathbf{S}_{\mathbf{v k}}[\mu \mathrm{m}]$ & Profundidade reduzida do Vale & Valores Altos \\
\hline
\end{tabular}




\subsection{Tensão Residual}

Muitas vezes, como resultado do mecanismo do evento unitário de usinagem, a superfície pode ser deixada em um estado de tensão após a usinagem. Mesmo sendo superficiais e limitadas a uma fina camada superficial, esta tensão pode ter uma influência significativa no desempenho funcional da peça. Geralmente tensão residual de compressão é preferida, pois tende a diminuir as tensões de tração externamente aplicadas e tendem a fechar trincas superficiais. As tensões residuais superficiais são balanceadas com as tensões residuais do núcleo de sinais inversos. A tensão residual varia entre processos e no processo, no último caso devido a diferentes condições de operação. A tensão residual pode ser alta ou baixa, positiva ou negativa e profunda ou não profunda.

Estas tensões são originadas sempre que o componente sofre deformação plástica localizada ou deformação elástica não-homogênea. Elas podem ser classificadas como macro ou microtensões residuais, em função da escala na qual se distribuem e seus efeitos podem ser benéficos ou prejudiciais ao componente, dependendo do sinal, magnitude e distribuição destas tensões (Fry, 2000 apud Martins et al, 2004). As tensões residuais podem melhorar o desempenho dos materiais frente às agressividades do meio externo e reduzir as falha por fadiga. Porém numa linha de manufatura, as tensões residuais podem gerar distorções no componente, tornando necessária à introdução de uma etapa posterior de processamento da peça no estado endurecido, encarecendo o processo. Assim, para se alcançar uma melhoria significativa no processo, design, controle de produto e desempenho de componentes mecânicos é necessário incorporar informações a respeito das tensões residuais e desenvolver métodos confiáveis para a sua determinação (Lu, 1996 apud Martins et al, 2004). 


\subsubsection{Mecanismos de Geração de Tensão Residual}

Segundo Griffiths (2001), os mecanismos de geração de tensão residual podem ser representados por três modelos: transformação de fase térmica, deformação termo/plástica e deformação plástica mecânica.

No primeiro modelo (transformação de fase térmica) a tensão residual é causada por uma mudança de volume de estrutura. Se a mudança causa uma diminuição de volume, a superfície irá contrair, porém o núcleo irá resistir. O resultado neste caso é tensão residual de tração. Se a transformação de fase térmica causa uma expansão, o resultado é de tensão residual de compressão. No segundo modelo (deformação termo/plástica) o evento de aquecimento causa expansão da superfície e esta expansão é aliviada (enquanto o calor é mantido) pelo fluxo plástico, que é restrito à camada superficial. No terceiro modelo (deformação plástica mecânica), a tensão residual é de compressão por causa da compactação superficial exercida por alguma forma de ação mecânica, não existem efeitos térmicos. Em processos que consistem somente de eventos unitários químicos a tensão residual é zero.

A Figura 71 , para o aço AISI 4340, mostra que tratamentos térmicos convencionais produzem tensão residual de compressão devido à expansão de volume, este é um exemplo do primeiro modelo. Quando esta superfície é jateada com esferas a tensão residual é de compressão devido aos "impactos", este é um exemplo do terceiro modelo. Retificação produz tensões residuais variáveis. Em condições severas de operação, eventos térmicos dominam e a tensão residual é de tração. Este é um exemplo do segundo modelo. Em eventos unitários de operação leve a refrigeração é melhorada e o atrito diminuído, por conta do uso de fluidos refrigerantes, o evento unitário se torna mecânico e a tensão residual resultante é de compressão. Em condições convencionais são produzidas tensões residuais que são tão elevadas quanto às obtidas em condições abusivas moderadas, novamente por causa da tendência do evento ser predominantemente térmico (Field e Kahles, 1972). Por conta desta similaridade nos picos de tensão residual, o limite de resistência à fadiga é praticamente o mesmo. 


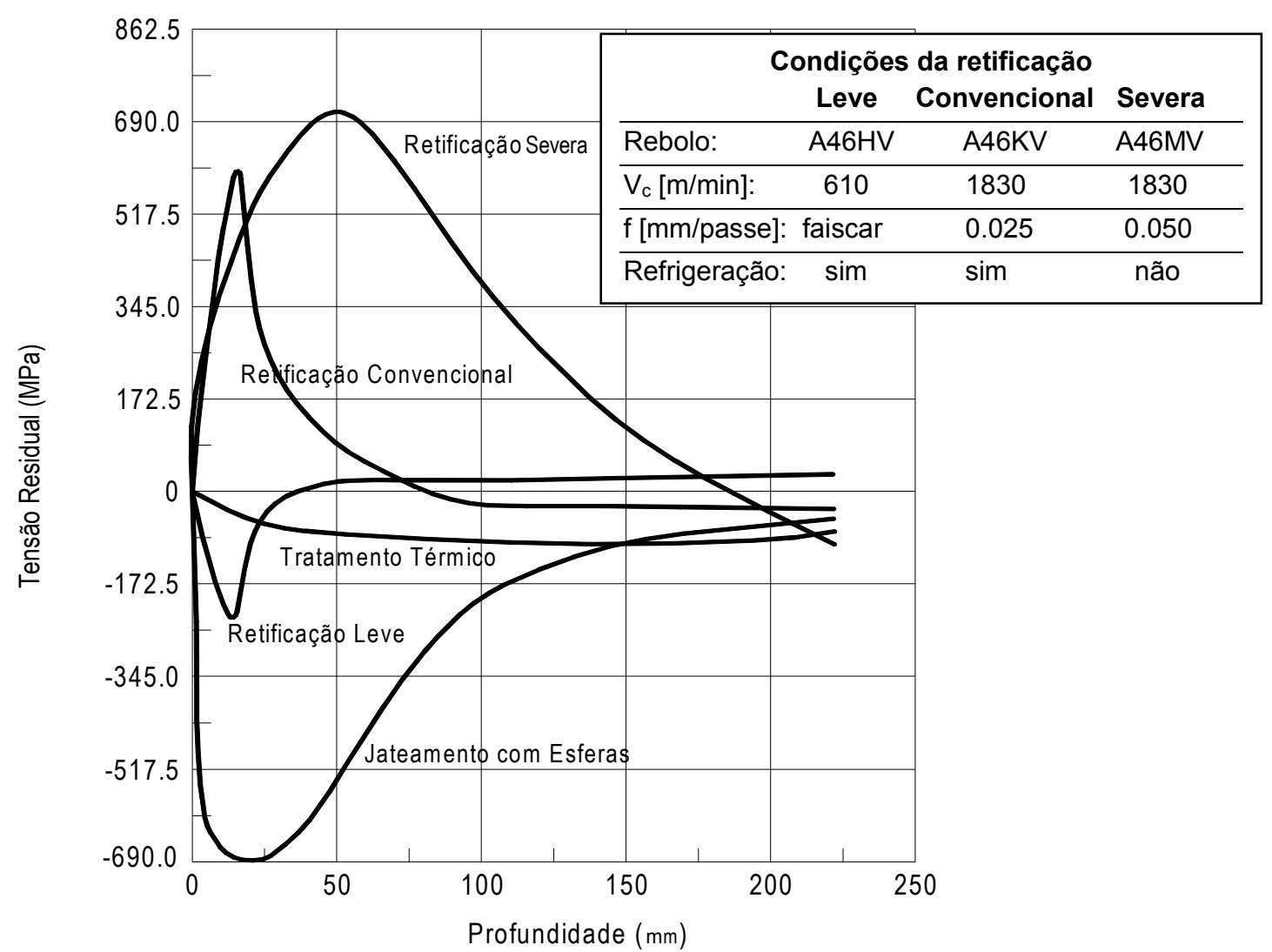

Figura 71. Tensão residual em vários processos para o aço AISI 4340 temperado e revenido com 510 HV (50 HRC) (Field e Kahles, 1972).

Se uma superfície é produzida por uma série de operações sequenciais, a tensão residual final é diferente da tensão residual produzida por uma operação somente. Isto se dá devido a superposição das tensões individuais dos processos. Por exemplo, se uma superfície retificada convencionalmente (tensão de tração) é jateada com esferas (tensão de compressão) o padrão de tensão final será a superposição das duas tensões individuais. Assumindo que os dois padrões de tensão da Figura 71 possam ser combinados o pico de tensão residual será próximo de zero. No entanto se a seqüência do processo for invertida a tensão residual final não será a mesma. Isto se dá por causa da remoção de material executada pela retificação que irá remover a camada atacada com as esferas. Portanto a magnitude e sinal do padrão de tensão, tal como a sequência dos processos irão influenciar a tensão residual final.

A Figura 72 apresenta a distribuição das tensões residuais ao longo da subcamada geradas por torneamento duro seguido de retificação com cinta de lixa em aço para rolamento com 700 HV (60HRC). Grzesik et al (2006) apresenta na Figura 72, que a combinação de dois processos, torneamento duro seguido 
retificação com cinta de lixa, gerou maior valor em módulo de tensão de compressão na superfície do material do que somente o processo de torneamento duro.

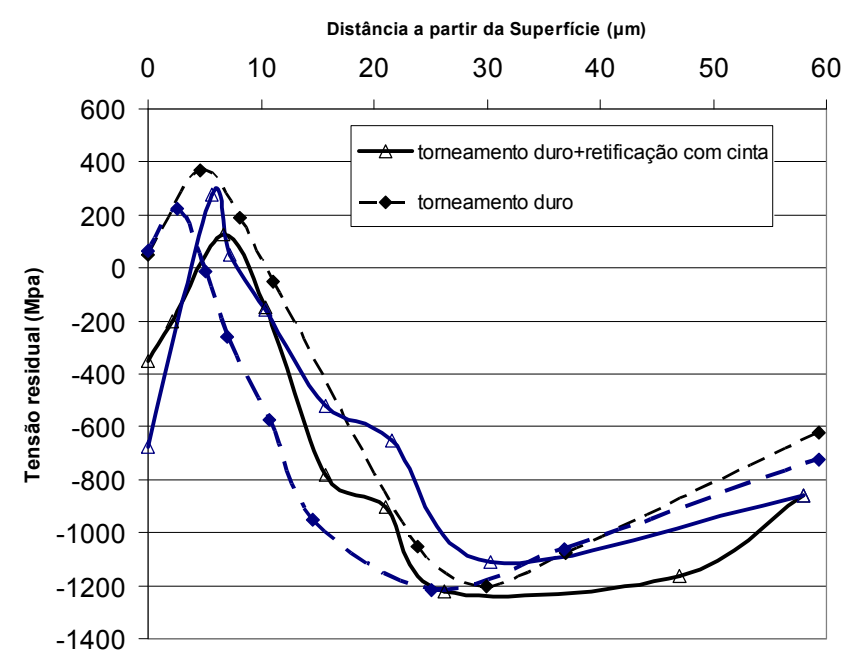

Figura 72. Distribuição da tensão residual em sub-camadas obtida por torneamento duro com CBN seguido de retificação com cinta de lixa (Grzesik et al, 2006).

A magnitude e o sinal da tensão residual terão um efeito significante no desempenho funcional. Por exemplo, considerando resistência à fadiga, se a tensão é de compressão, a vida da peça será maior do que se a tensão fosse de tração. Metcut (1980) mostrou que existe uma relação inversa entre resistência à fadiga e pico de tensão residual para retificação, Figura 73.

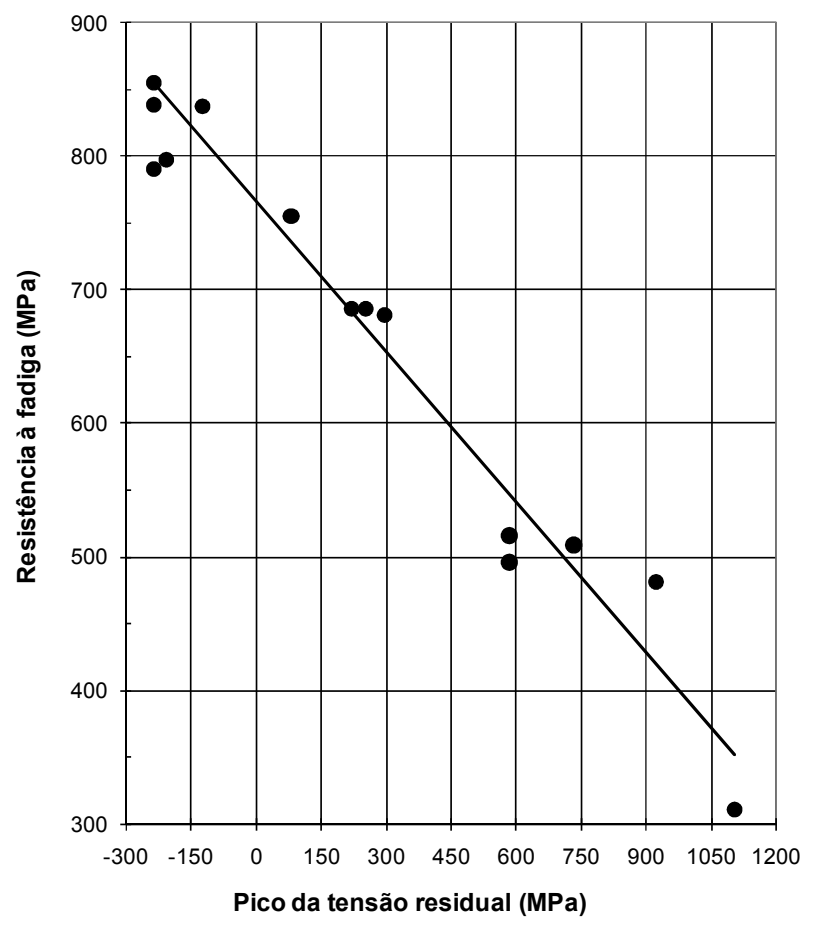

Figura 73. Tensão residual e resistência à fadiga (Metcut, 1980). 
Matsumoto et al (1999), relacionaram o efeito das tensões residuais no desempenho da resistência à fadiga de materiais submetidos a processos de usinagem de torneamento e retificação de material endurecido. Em seu estudo foi demonstrado que a resistência à fadiga de uma peça com níveis maiores de tensão compressiva obtidas no processo de torneamento é superior quando comparado com a condição de retificação.

A Tabela 9 mostra a faixa de tensão residual produzida por uma gama de processos de manufatura. Em geral processos que possuem predominância em eventos unitários mecânicos tendem a produzir tensão de compressão, e processos termicamente dominantes tendem a produzir tensão de tração.

Tabela 9. Tensão residual produzidas por alguns processos de usinagem (Griffiths, 2001).

\begin{tabular}{ll}
\hline \hline $\begin{array}{c}\text { Tensão } \\
\text { residual }\end{array}$ & \multicolumn{1}{c}{ Processo de manufatura } \\
\hline \multirow{2}{*}{ Tração } & $\begin{array}{l}\text { Torneamento, Fresamento de topo, Fresamento discordante, Retificação abusiva } \\
\text { com óxido de alumínio e emulsão, Retificação convencional com óxido de } \\
\text { alumínio e emulsão, Eletro-erosão. }\end{array}$ \\
\hline Zero & Usinagem química, Usinagem eletro-química. \\
\hline \multirow{2}{*}{ Compressão } & Esferoidização, Jateamento com areia, Usinagem com jato abrasivo, \\
& Tamboreamento, Polimento, Brunimento, Fresamento concordante, Retificação \\
& leve com óxido de alumínio e emulsão, Retificação com CBN, Tratamento \\
& térmico, Cementação, Nitretação. \\
\hline \hline
\end{tabular}

2.5.2 Influência dos Parâmetros de Torneamento na Tensão Residual

\subsubsection{Preparação de Aresta}

Segundo Brinksmeier et al. (1982), os processos mecânicos de transformação geram tensões residuais por deformação plástica ou por transformação de microestrutura. A ação da ponta da ferramenta contra a peça durante o torneamento, gera deformação plástica no material usinado na região de corte, assim como os 
atritos entre a ferramenta e o cavaco e o cavaco e a peça geram variações térmicas que provocam transformações. Segundo Matsumoto et al (1999) e Guo e Wen (2004), o torneamento em material endurecido possui a capacidade de gerar tensões residuais de compressão em maiores profundidades quando comparado ao processo de retificação.

O estudo de Thiele e Melkote (1999), Matsumoto et al (1999) e mais recentemente Hua et al (2006) e Javidi et al (2008), mostram que a geometria da aresta da ferramenta exerce grande influência na geração de tensão residual. Em geral arestas arredondadas ou chanfradas são as mais indicadas Figuras 74(a), 74(b) e 75. Hua et al (2006) ressaltam ainda que a preparação com chanfro mais raio de arredondamento, Figura 75 , é a melhor condição de ferramenta para geração de tensão residual de compressão.

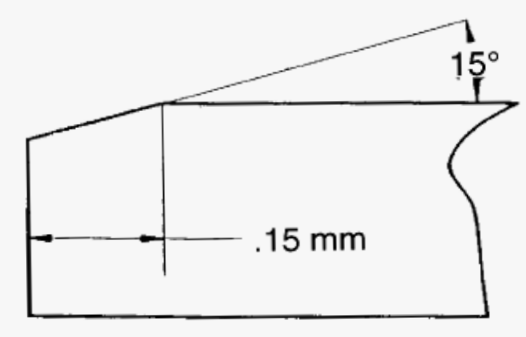

(a)

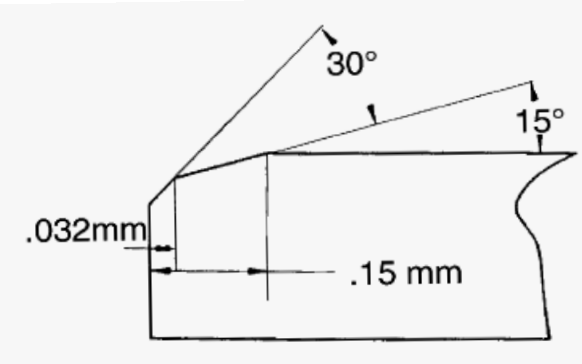

(b)

Figura 74. Preparação de aresta (a) chanfro simples e (b) chanfro duplo (Matsumoto et al, 1999).

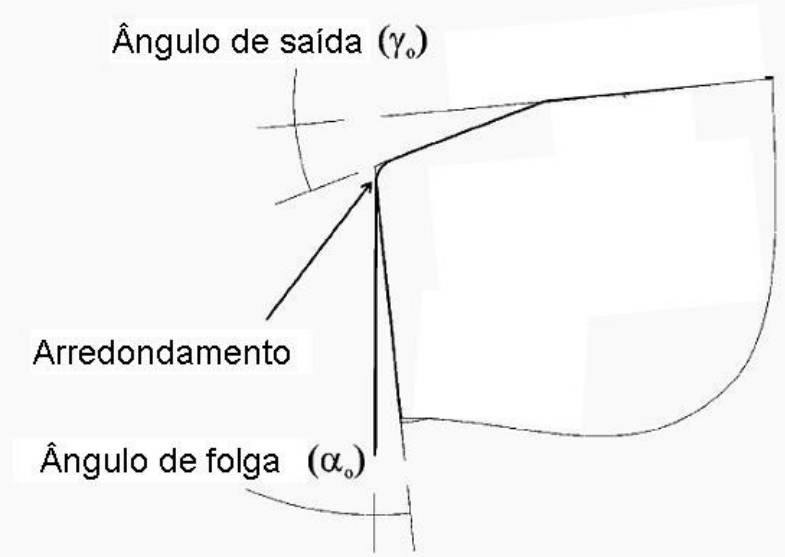

Figura 75. Preparação de aresta com chanfro e raio (Gunnberg et al, 2006). 


\subsubsection{Velocidade de Corte, Avanço e Profundidade de Corte}

Diversos autores, (Thiele e Melkote, 1999, Matsumoto et al, 1999, Delijaicov, 2004, Abrão, 2005, Hua et al, 2006, Javidi et al, 2008) apresentam em seus trabalhos constatações que o avanço (f) exerce forte influência na geração de tensões residuais de compressão, sendo o principal parâmetro associado e esta condição.

Já a profundidade de corte $\left(\mathrm{a}_{\mathrm{p}}\right)$ e a velocidade de corte $\left(\mathrm{V}_{\mathrm{c}}\right)$ causam discordância entre os resultados de pesquisadores, não revelando uma clara correlação na geração das tensões residuais e não podendo ser afirmado como fatores preponderantes. Segundo Matsumoto et al (1999) e Dahlman et al (2004) o parâmetro $a_{p}$ não influencia a condição de tensão residual final da peça usinada. Já as conclusões de Delijaicov, (2004) e Bordinassi (2006) indicam que a variação da profundidade de corte $\left(a_{p}\right)$ pode influenciar a condição de tensão residual.

Gunnberg et al (2006) menciona que em um dos seus experimentos a $V_{c}$ influenciou negativamente gerando tensões residuais de tração. E segundo Rech e Moisan (2003) a $V_{c}$ exerce forte influência na condição final da tensão residual de compressão.

\subsubsection{Medição da Tensão Residual}

Segundo Martins et al (2004), até o momento não existe um método universal de medida das tensões residuais capaz de resolver todos os problemas, a baixo custo, da melhor maneira possível. A técnica a ser utilizada deve ser selecionada com base numa série de parâmetros influenciados pelas características do componente e o tipo de medida a ser efetuada. Segundo os estudos de Martins et al (2004), a escolha do método mais apropriado está baseado: 
- Na natureza do componente;

- No tipo de tensões residuais presentes no componente;

- No gradiente de tensões residuais;

- Na geometria do componente;

- Em onde a medida será realizada (em campo ou no laboratório);

- No tipo de intervenção (método destrutivo ou não-destrutivo);

- No tempo disponível para a medida e apresentação dos resultados;

- Na precisão e a repetibilidade do método;

- No custo final da medida (Lu, 1996 apud Martins et al, 2004).

Existem diversas formas de se obter os valores de tensão residual. Ya et al (2003) citam o método dos furos de alívio de deformação, interferometria laser, interferometria holográfica e a interferometria de Moiré utilizadas em seu trabalho. Brinksmeier et al (1982) citam vários métodos, como extensômetros, métodos magnéticos, eletromagnéticos e ultrassônicos. Lindgen e Lepisto (2003) apud Bordinassi (2006) citam que atualmente os dois métodos mais utilizados são o dos furos e por difração de raios- $X$, sendo este último o mais utilizado. Martins et al (2004) citam que o método por difração de raios- $X$ apresenta os melhores resultados, quando comparado com o método micromagnético e método do furo cego incremental.

Os métodos utilizados neste trabalho foram: Método do furo cego incremental e método da difração de raios-X que são discutidos adiante.

\subsubsection{Método do Furo Cego Incremental}

O método de medição das tensões residuais pela técnica do furo cego para alívio das tensões é uma das técnicas modernas mais utilizadas atualmente. $\mathrm{O}$ procedimento de medição é relativamente simples e foi padronizado em um método padrão de testes pela ASTM e recebeu o número ASTM E837. Com a utilização de equipamentos comercialmente disponíveis (Figura 76 e 77) e das recomendações da norma, o método do furo pôde ser aplicado rotineiramente. 
O método é muito versátil, podendo ser aplicado em qualquer laboratório ou no campo sobre corpos de prova ou peças com grande variedade de tamanho e forma.

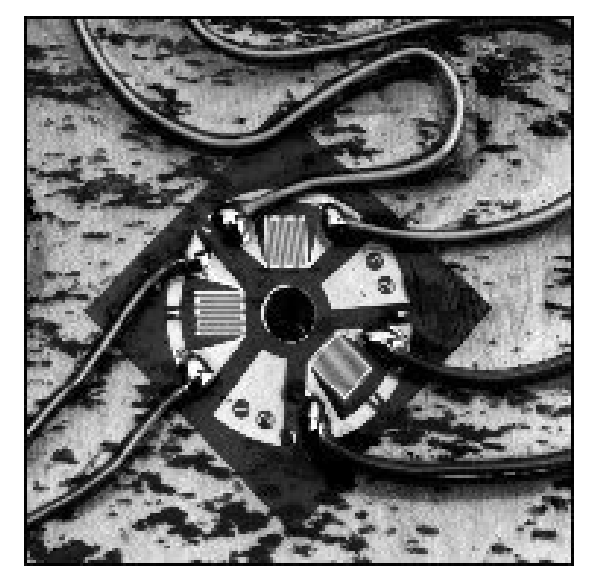

Figura 76. Extensômetro Roseta (strain gage) para medição do processo de furo cego (Vishay-Measurements Group, 2007).

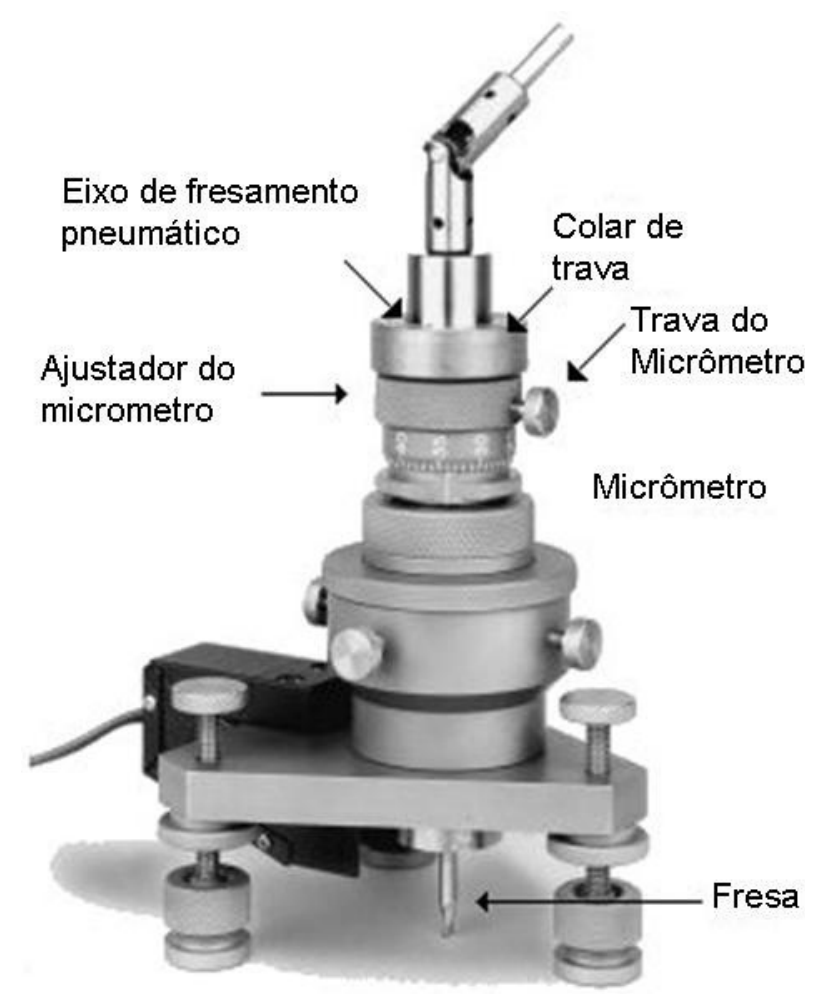

Figura 77. Detalhes do dispositivo para furação (Vishay-Measurements Group, 2007).

A técnica é referida frequentemente como "semidestrutiva" uma vez que o pequeno furo mostrado na Figura 78 não irá, em muitos casos, provocar danos significativos na integridade estrutural do objeto que está sendo testado. O furo 
possui tipicamente diâmetro de 0,8 a 4,8 mm e profundidade igual a $20 \%$ superior ao diâmetro para campos de tensão uniformes e $50 \%$ superior para campos de tensão não uniformes.

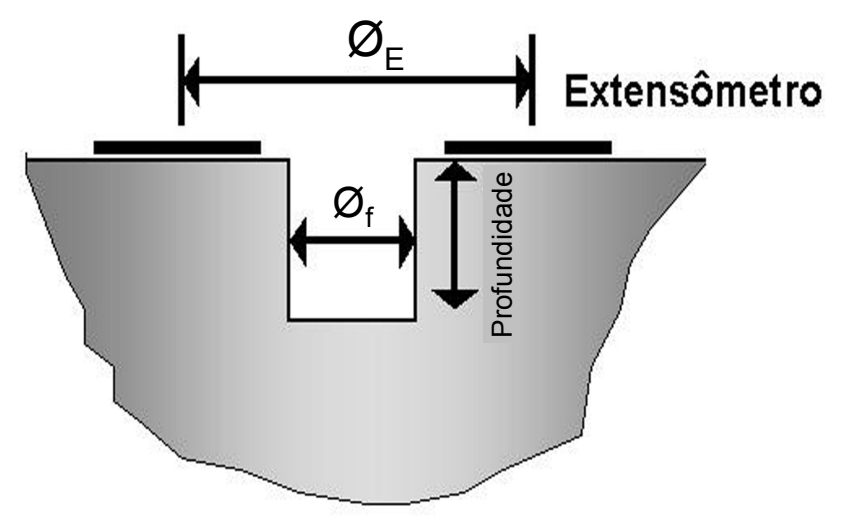

Figura 78. Relação entre as dimensões do extensômetro e as dimensões do furo (Martins et al, 2004).

Sendo: $\varnothing_{\mathrm{f}}$ é o diâmetro do furo;

$\varnothing_{E}$ é o diâmetro médio do extensômetro.

A introdução de um furo, mesmo de diâmetro pequeno, em um corpo com tensões residuais relaxa a tensão naquela localização. Isto ocorre porque a perpendicular a uma superfície livre é, necessariamente, um eixo principal no qual as tensões de cisalhamento e normal são zero.

Neste caso o eixo está representado pelo furo na superfície. A eliminação destas deformações, na superfície do furo, muda as tensões na região ao redor do furo, causando a correspondente mudança nas deformações locais na superfície do objeto testado. Esse é o princípio para esse método.

Na maioria das aplicações práticas do método, o furo não é passante, isto é, não atravessa a espessura da parede do objeto, denominando-se de técnica do "furo cego", com uma profundidade aproximadamente igual ao diâmetro que deverá ser muito pequena comparada com a espessura do objeto testado. Como a geometria do furo cego, em função dos efeitos de borda e deformação, é muito complexa, não há um cálculo direto para determinação da tensão residual a partir da teoria da elasticidade, exceto pela introdução de coeficientes empíricos. A solução, entretanto, pode ser obtida para o caso simples de um furo passante em uma chapa fina, na qual a tensão residual é uniformemente distribuída através de sua espessura, e 
estendida subsequentemente para aplicações técnicas do furo cego. Toda a teoria foi desenvolvida para uma placa larga, plana e sujeita a um plano de tensões estáveis e está longe dos objetos típicos da prática. Como as peças de máquinas e estruturais que são submetidas à análise de tensão residual podem ser de todos os tamanhos e formas (raramente são finas ou planas), a técnica do furo cego será utilizada na maioria das aplicações.

Quantitativamente, o método do furo cego apresenta ótimo desempenho quando comparado com outras técnicas. A incerteza de medição deste método, considerando o uso em campos de tensão uniformes e empregos de técnicas de medição adequadas, está entre 10 e $20 \%$ do valor medido ou $10 \%$ da tensão de escoamento (Prevey, 1996)

Como a formulação clássica considera a existência de campos de tensões residuais uniformes, nos casos em que a tensão varia com a profundidade, a tensão calculada é sempre menor do que a tensão máxima. Para avaliar a uniformidade da tensão ao longo da espessura e garantir o uso correto dos coeficientes de calibração é recomendada a realização da furação de maneira incremental, registrando-se as deformações ou deslocamentos bem como a respectiva profundidade.

\subsubsection{Método da Difração de Raios-X}

Através da técnica de difração de raios- $X$, a deformação causada na superfície é obtida pela razão da variação da distância interplanar pela distância interplanar livre de deformação, convertida em tensão, segundo equações derivadas da teoria da elasticidade (Lima, 1991), ou seja, a variação no retículo cristalino induzida pela presença de tensões, é medida com base na lei de Bragg e as tensões são calculadas assumindo-se que a distorção ocorre no regime linear elástico. É uma técnica não destrutiva, que devido à forte absorção dos raios-x pela matéria, é limitada às camadas superficiais onde estes percorrem distâncias da ordem de $10 \mu \mathrm{m}$ (Martins et al, 2004).

O método por dífratometria de raios- $X$ mede o parâmetro "d" do reticulado do corpo de prova e calcula as respectivas deformações existentes. A Figura 79 ilustra esta condição. Desta forma, somente a parte elástica do campo de deformações é medida, uma vez que a deformação plástica não afeta os parâmetros 
cristalinos.
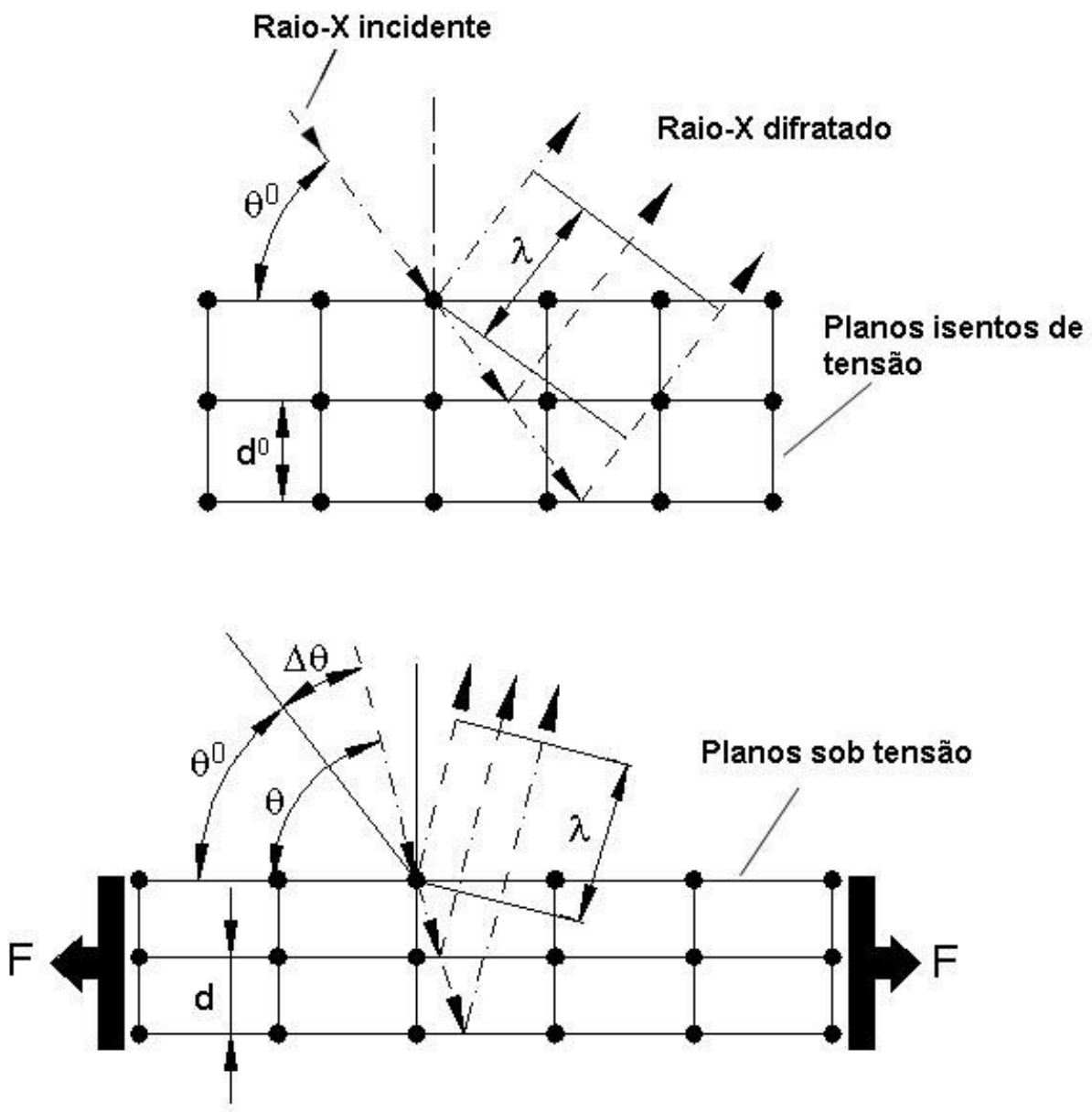

Figura 79. Difração de raios- $X$ em cristais simples carregados e descarregados (Brinksmeier et al, 1982).

Bragg descreve a difração de raios-X como uma reflexão seletiva segundo certos planos cristalográficos, (Barralis e Maeder ,1982), Figura 79, de acordo com a seguinte lei:

$$
2 d \operatorname{sen} \theta=\lambda
$$

Onde $d$ é um parâmetro do reticulado, $\theta$ é o ângulo de refração e $\lambda$ é o comprimento de onda dos raios-X. 
A derivada da expressão de Bragg indica que:

$$
\begin{aligned}
& \frac{\Delta d}{d}+\frac{\cos \theta}{\operatorname{sen} \theta} \cdot \Delta \theta=0 \\
& \varepsilon=-\Delta \theta \cdot \cot g \theta \\
& \Delta \theta=\theta_{\text {com tensão }}-\theta_{\text {sem tensão }}
\end{aligned}
$$

Medindo-se $\Delta \theta$ pode-se calcular a deformação $\varepsilon$, e consequentemente a respectiva tensão residual $\sigma$.

Vários métodos são propostos para determinação das deformações $\varepsilon$ segundo a difração de raios-X (Damasceno, 1999, Brinksmeier et al, 1982):

- Método do $\operatorname{sen}^{2} \psi$

- Método de Glocker ou método do $0^{\circ}-45^{\circ}$

- Método de Schall ou método da única incidência de $45^{\circ}$

- Método $\theta-2 \theta$

- Método $\theta$ ou método do eixo fixo

Não faz parte dos objetivos deste trabalho o detalhamento de todos os possíveis métodos existentes, portanto somente o método do $\operatorname{sen}^{2} \psi$ será estudado por ser utilizado na parte experimental.

\subsubsection{Método do $\operatorname{sen}^{2} \psi$}

Na Figura 80 pode-se observar os princípios do método do $\operatorname{sen}^{2} \psi$ ( $\psi$ é o ângulo entre a reta normal à superfície da peça e a reta normal ao plano de parâmetro "d"). Para cada orientação $\psi$, certos planos cristalográficos se colocam em posição de difração, conforme se observa através das Figuras 80 e 81 . A penetração dos raios- $X$ é extremamente rasa $(<10 \mu \mathrm{m})$, portanto a condição de estado plano de tensões é assumida na camada da superfície de difração (Prevéy, 1996). 
Segundo Guimarães (1990) apud Bordinassi (2006), esta técnica é utilizada e recomendada quando se deseja grande exatidão nas medidas e quando a amostra apresenta certo grau de textura.

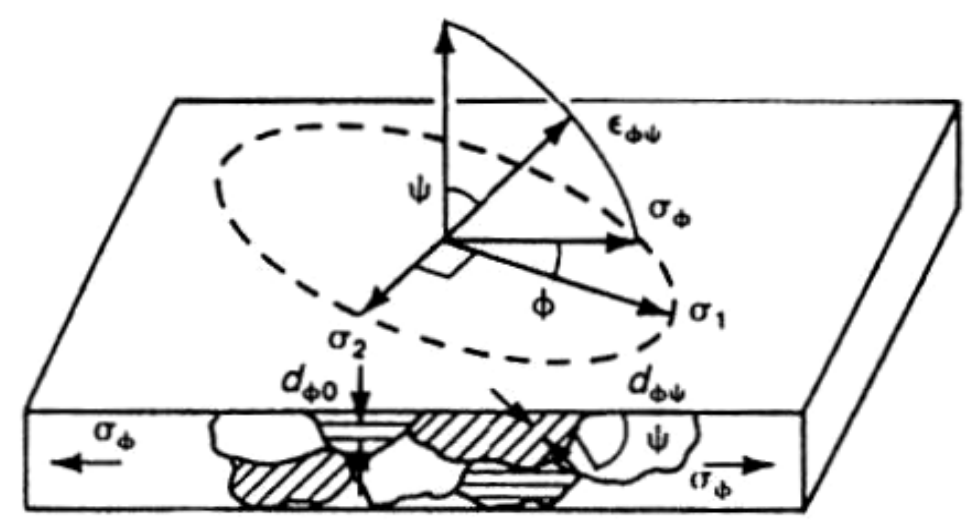

Figura 80. Estado plano de tensões (Prevéy, 1996).

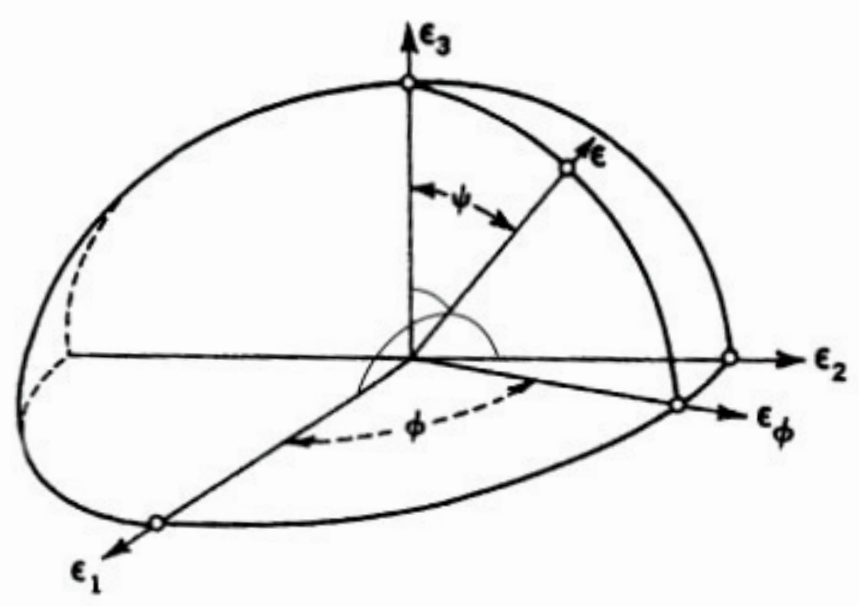

Figura 81. Elipsóide das deformações (Prevéy, 1996).

As direções principais das figuras anteriores podem ser dadas pelas Equações de 24 a 26:

$$
\begin{aligned}
& \alpha_{1}=\cos \phi \cdot \operatorname{sen} \psi \\
& \alpha_{2}=\operatorname{sen} \phi \cdot \operatorname{sen} \psi \\
& \alpha_{3}=\cos \psi=\sqrt{\left(1-\operatorname{sen}^{2} \psi\right)}
\end{aligned}
$$


A lei da transformação do tensor das deformações em relação às direções principais é escrita como:

$$
\varepsilon=\alpha_{1}^{2} \cdot \varepsilon_{1}+\alpha_{2}^{2} \cdot \varepsilon_{2}+\alpha_{3}^{2} \cdot \varepsilon_{3}
$$

Sabendo que:

$$
\varepsilon_{i}=\frac{1}{E} \cdot\left[\sigma_{i}-v\left(\sigma_{j}+\sigma_{k}\right)\right.
$$

Para $i, j, k=1,2,3$

Após transformação obtemos:

$$
\varepsilon=\frac{\Delta d}{d}=\left(\frac{1+v}{E}\right) \sigma_{\phi} \operatorname{sen}^{2} \psi-\left(\frac{v}{E}\right)\left(\sigma_{1}+\sigma_{2}\right)
$$

Onde:

$$
\sigma_{\phi}=\sigma_{1} \cos ^{2} \phi+\sigma_{2} \operatorname{sen}^{2} \phi
$$

Derivando-se a expressão de $\varepsilon$ em relação a $\operatorname{sen}^{2} \psi$, obtem-se:

$$
\sigma_{\phi}=\frac{E}{(1+v)} \cdot \frac{\partial\left(\frac{\Delta d}{d}\right)}{\partial\left(\operatorname{sen}^{2} \psi\right)}
$$

E substituindo com a Lei de Bragg:

$$
\sigma_{\phi}=-\frac{E}{2(1+v)} \cdot \frac{\pi}{180} \cdot \cot g \theta \cdot \frac{\partial(2 \theta)}{\partial\left(\operatorname{sen}^{2} \psi\right)}
$$


Ou ainda:

$$
\sigma_{\phi}=-K . \varphi
$$

Onde:

$$
\varphi=\frac{\partial(2 \theta)}{\partial\left(\operatorname{sen}^{2} \psi\right)}
$$

Sendo $K$ um fator constante tabelado para o plano de difração escolhido em função do material do corpo de prova, que no caso deste trabalho para o aço ABNT 8620 vale $-30.33 \mathrm{MPa}$.

$E \varphi$ é o coeficiente angular da reta $\left(2 \theta-\operatorname{sen}^{2} \psi\right)$, obtida pela plotagem das variações dos ângulos de difração $2 \theta$ com as variações dos ângulos de incidência dos raios-X (Figura 82).

O método consiste em variar o ângulo $\psi$ de $-60^{\circ} \mathrm{a}+60^{\circ}$, em incrementos de $10^{\circ}$, obter os respectivos ângulos de difração e traçar uma reta por regressão, pelo método os mínimos quadrados, através destes pontos.

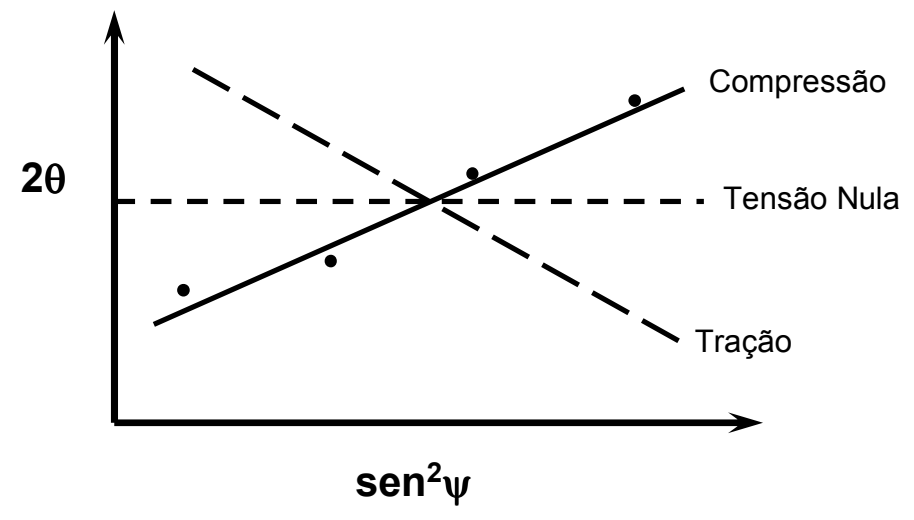

Figura 82. Gráfico $\left(2 \theta-\operatorname{sen}^{2} \psi\right)$ (Prevéy, 1996). 


\section{PROCEDIMENTO EXPERIMENTAL}

Foram investigados 36 corpos de prova, sendo 6 réplicas para cada combinação de velocidade de corte e avanço, retirados de peças industriais como mostra a Figura 83, (Polimold, 2008), torneadas em condições convencionais para produção em massa. Não foi possível utilizar um estudo fatorial devido a restrições e necessidades das empresas que auxiliaram nos testes de usinagem, porém os dados de interesse foram agrupados e analisados convenientemente de forma estatística. Adicionalmente, foram executadas análises em três corpos de prova, idênticos aos utilizados no torneamento, obtidos pelo processo de retificação em condições convencionais para produção com o intuito de apresentar uma comparação básica entre os dois processos.

\subsection{Corpos de Prova}

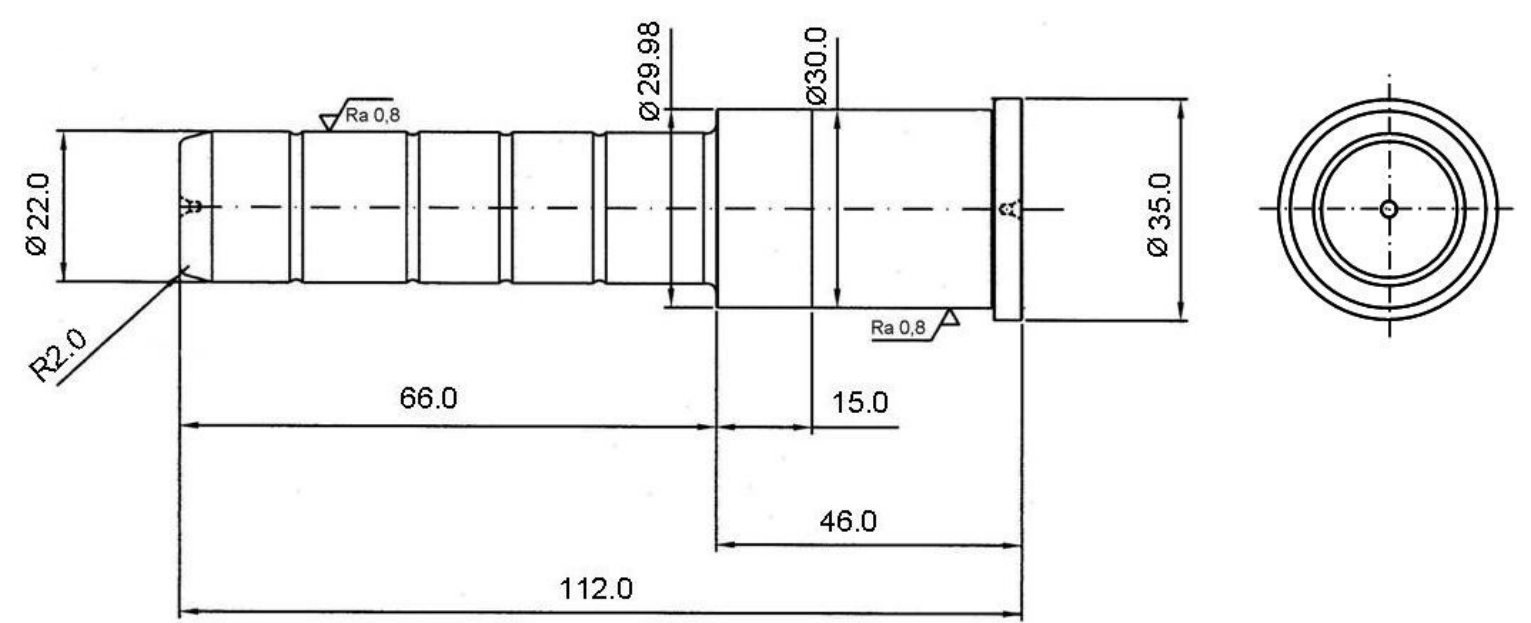

Figura 83. Representação simplificada do corpo de prova utilizado no experimento de torneamento endurecido.

O material dos corpos de prova é o aço ABNT 8620, cuja composição química é apresentada na Tabela 10 e equivalências entre normas na Tabela 11, é amplamente utilizado na fabricação de engrenagens, pinos e peças onde há exigência de dureza superficial (resistência ao desgaste) conciliada a uma tenacidade no núcleo. 
O material foi cementado em banho de sal (cementação líquida) e após o tratamento térmico de cementação o teor de carbono na região superficial da peça foi aumentado para aproximadamente 1,0\%. Posteriormente o material foi temperado e revenido para a dureza de 660 a $750 \mathrm{HV}$ (58 a 62HRC), onde sua tensão de escoamento na condição temperada e revenida pode chegar a $965 \mathrm{MPa}$ (Metals Handbook, 1998).

Tabela 10. Composição química em \%peso conforme Norma SAE - J404.

\begin{tabular}{|c|c|c|c|c|c|c|c|c|}
\hline ABNT & $\mathbf{C}$ & $\mathbf{M n}$ & $\mathbf{P}$ máx. & $\mathbf{S}$ máx. & $\mathbf{S i}$ & $\mathbf{N i}$ & $\mathbf{C r}$ & Mo \\
\hline $\mathbf{8 6 2 0}$ & $0,18-0,23$ & $0,70-0,90$ & 0,035 & 0,040 & $0,15-0,35$ & $0,40-0,70$ & $0,40-0,60$ & $0,15-0,25$ \\
\hline
\end{tabular}

Tabela 11. Normas de equivalências do aço ABNT 8620.

\begin{tabular}{|c|c|c|c|c|}
\hline ABNT/SAE/AISI & DIN & JIS & BS & AFNOR \\
\hline $\mathbf{8 6 2 0}$ & 21 Ni Cr Mo 2 & SNCM 21 & 805 M 20 & 20 NCD 2 \\
\hline
\end{tabular}

\subsection{Ferramenta e Máquina}

\subsubsection{Torneamento}

Dados da ferramenta utilizada, Figura 84:

- Inserto de cBN com 50\% de volume em matriz de liga TiC: TNGX110308SWZ, CBN100; Raio de ponta 0.8mm, geometria Wiper, Fabricante Seco Tools Brasil;

- Suporte: CTJNL2525M11, Fabricante Seco Tools Brasil;

- Ângulos de ferramenta: Ângulo de posição da ferramenta $x_{r}=93^{\circ}$; Ângulo de inclinação da ferramenta $\lambda_{s}=-6^{\circ}$; Ângulo de saída da ferramenta $\gamma_{r}=-6^{\circ}$;

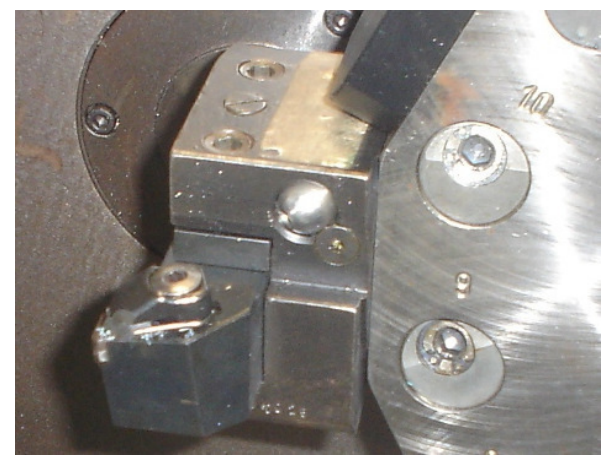

Figura 84. Ferramenta montada na torre de ferramentas do torno. 
A máquina ferramenta utilizada foi um centro de torneamento computadorizado marca INDEX modelo MC400, Figura 85. Os parâmetros de corte utilizados são apresentados na Tabela 12:

Tabela 12. Dados de corte da usinagem.

\begin{tabular}{|l|c|c|c|}
\cline { 2 - 4 } \multicolumn{1}{c|}{} & $\mathbf{V}_{\mathbf{c}}$ & $\mathbf{f}$ & $\mathbf{a}_{\mathbf{p}}$ \\
\cline { 2 - 4 } \multicolumn{1}{c|}{} & {$[\mathrm{m} / \mathrm{min}]$} & {$[\mathrm{mm} / \mathrm{rot}]$} & {$[\mathrm{mm}]$} \\
\hline Condição 1 & 180 & 0.05 & 0.18 \\
\hline Condição 2 & 180 & 0.08 & 0.18 \\
\hline Condição 3 & 180 & 0.12 & 0.18 \\
\hline Condição 4 & 200 & 0.05 & 0.18 \\
\hline Condição 5 & 200 & 0.08 & 0.18 \\
\hline Condição 6 & 200 & 0.12 & 0.18 \\
\hline
\end{tabular}

Sendo $\quad V_{c}$ : Velocidade de Corte em $[\mathrm{m} / \mathrm{min}]$;

f: $\quad$ Avanço em [mm/rot];

$\mathrm{a}_{\mathrm{p}}$ : $\quad$ Profundidade de Corte em [mm];

Para cada mudança no par velocidade de corte $\left(V_{c}\right)$ e avanço (f) a ponta do inserto foi trocada, portanto para todas as análises não foi considerado o desgaste da ferramenta. A usinagem dos corpos de prova foi conduzida a seco.

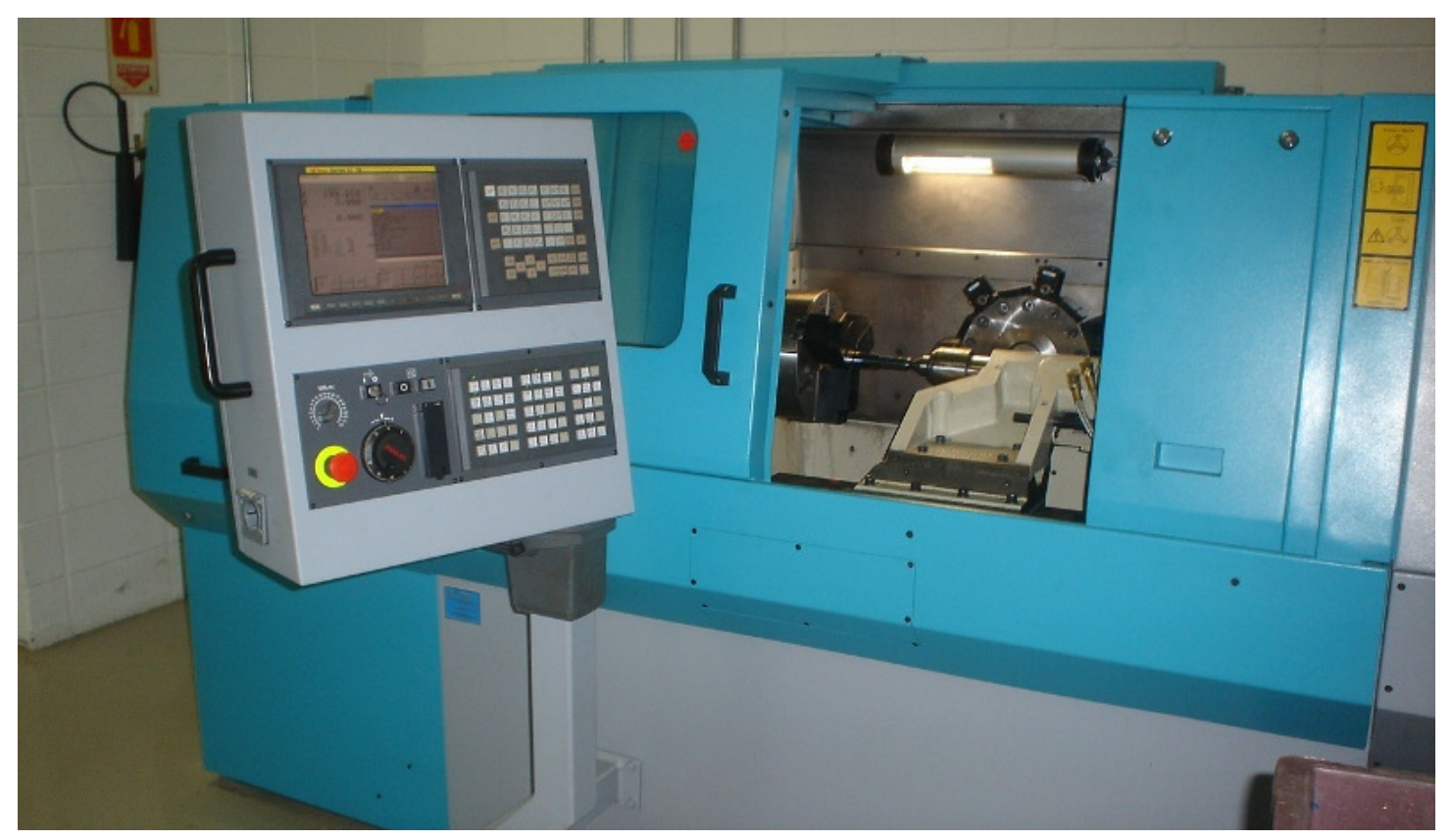

Figura 85. Centro de torneamento computadorizado marca INDEX MC400. 
O corpo de prova foi fixado através de uma placa de três castanhas e apoiado com um contraponto giratório no mangote da máquina, como mostra a Figura 86.

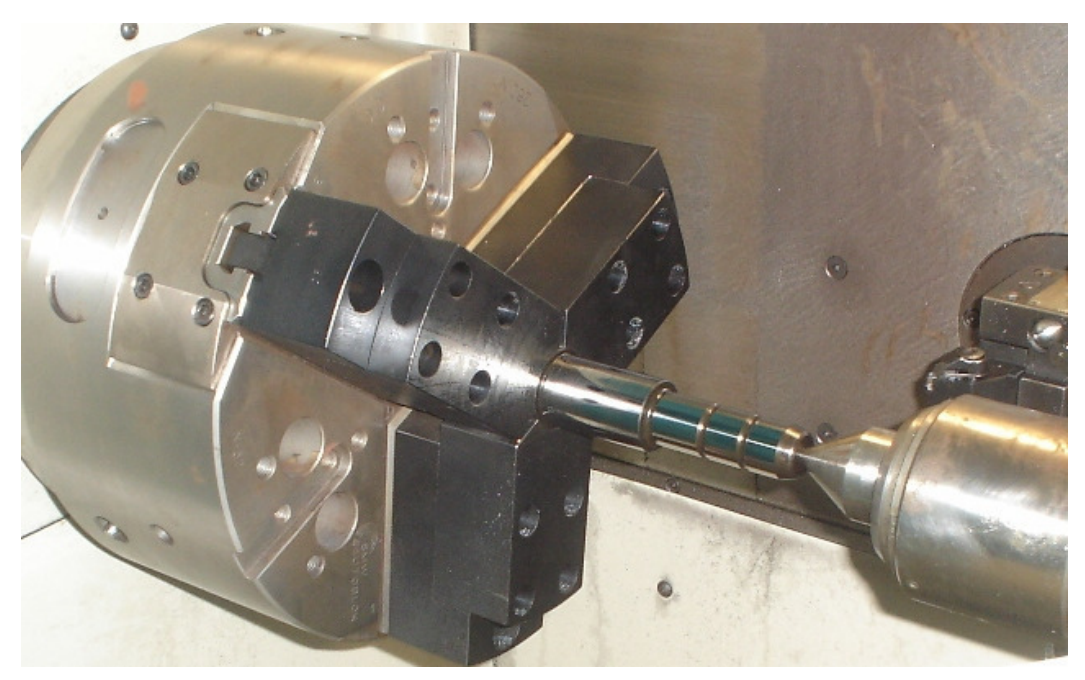

Figura 86. Fixação do corpo de prova.

Os testes foram conduzidos sem o uso de fluidos de corte ou refrigeração como mostra a Figura 87.

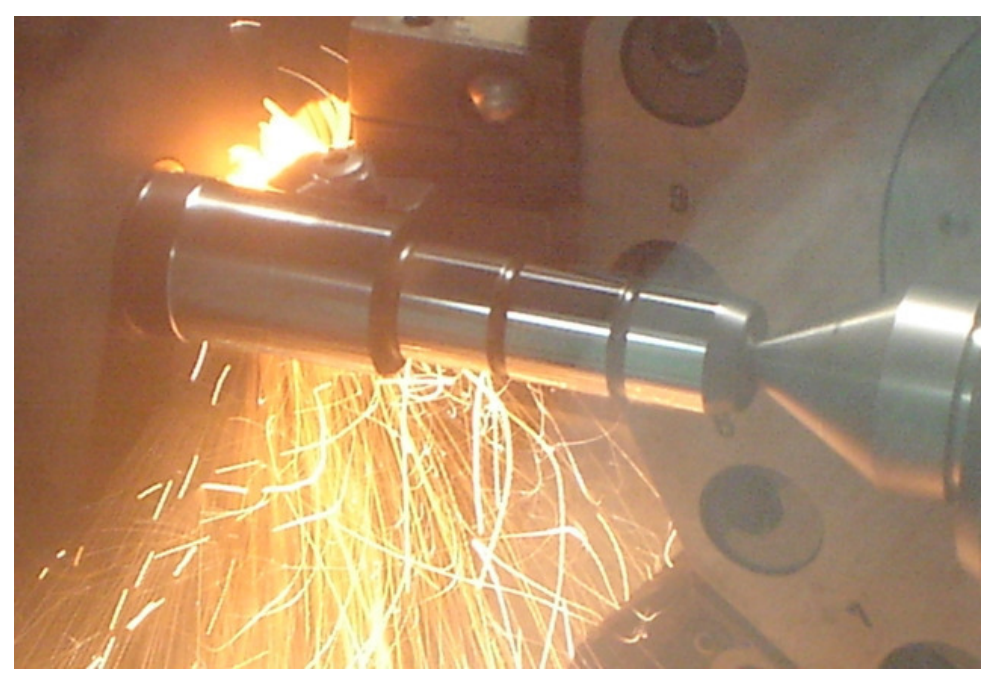

Figura 87. Usinagem de um corpo de prova sem fluido de refrigeração ou corte.

Após a usinagem, cada corpo de prova foi identificado com uma numeração e seus parâmetros de corte registrados em uma planilha conforme Anexo-A. Óleo protetor foi aplicado visando evitar oxidações posteriores que possam comprometer as análises. 


\subsubsection{Retificação}

Adicionalmente três peças usinadas em condições convencionais de retificação (processo original utilizado para usinagem de acabamento deste componente) foram preparadas para levantamento de comparações entre os processos, uma vez que este trabalho tem como finalidade a verificação da viabilidade técnica em substituir um processo já estabelecido.

As condições utilizadas para retificação foram:

- Rebolo de óxido de alumínio;

- Granulometria do rebolo de $100 \mu \mathrm{m}$;

- Fixação entre centros;

- Velocidade de corte $45 \mathrm{~m} / \mathrm{s}(2.700 \mathrm{~m} / \mathrm{min})$;

- Taxa de avanço de $400 \mathrm{~mm} / \mathrm{min}$;

- Profundidade de corte de $5 \mu \mathrm{m}$ por passada;

- Três passes para faiscamento com taxa de avanço de $600 \mathrm{~mm} / \mathrm{min}$.

\subsection{Medição da Tensão Residual pelo Método do Furo Cego}

As tensões residuais experimentais foram levantadas por meio do método do furo cego incremental utilizando o equipamento RS-200 Milling Guide, da Vishay Micro-Measurements Group (Figura 88), com avanço incremental manual para a aquisição dos valores de deformação a cada passo nas três direções conhecidas.

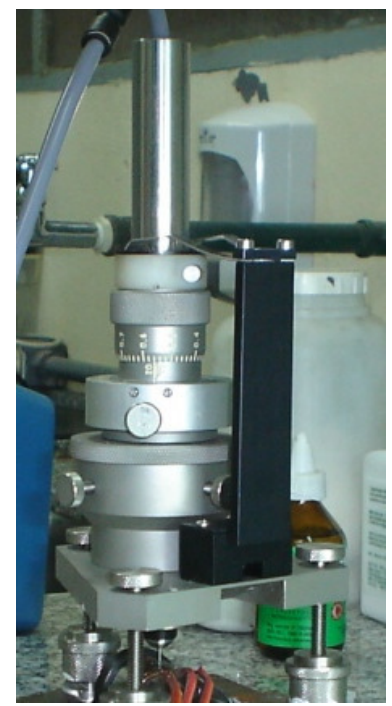

Figura 88. Dispositivo para usinagem do furo para alívio de deformações. 
A Figura 88 apresenta o sistema de fixação para usinagem do furo utilizado no experimento (Vishay Micro-Measurements Group, 2007). Os valores das deformações foram tratados e analisados com o auxílio do software $\mathrm{H}$-Drill pelo método integral (Calle, 2004). Para análise das tensões residuais foi utilizada uma amostra para cada condição de torneamento em material endurecido efetuada, portanto seis amostras usinadas foram analisadas. Visando obter um melhor entendimento da condição das tensões residuais nas peças torneadas em material endurecido executaram-se adicionalmente análises de tensões residuais em mais dois corpos de prova: um na condição anterior à usinagem (condição cementada) e outro corpo de prova sujeito à usinagem por retificação.

\subsubsection{Procedimento para Instrumentação dos Corpos de Prova para o Método do Furo Cego}

Por se tratar de um material de alta dureza, foram adotados os seguintes procedimentos visando obter bons resultados experimentais:

- Selecionar a região onde irá ser colado o extensômetro levando em consideração as dimensões do mesmo (Extensômetro PA-06-062RE-120L, Exel Sensors);

- Lixar com a lixa de granulometria G80 com o auxílio do condicionador (Condicionador, Exel Sensors);

- Com a mesma lixa de granulometria G80 fazer ranhuras a 45 graus na região a ser instrumentada com auxilio do condicionador;

- Traçar as linhas para o posicionamento do extensômetro com o auxílio do traçador de altura;

- Neutralizar a superfície com uma gaze embebida em neutralizador (Neutralizador, Exel Sensors) até a gaze ficar completamente limpa;

- Posicionar o extensômetro próximo ao corpo de prova com sua face voltada para baixo;

- Passar o ativador (Ativador-7452, Loctite) e aguardar por um minuto;

- Passar a cola (Cola-756, Loctite) e posicionar o extensômetro no corpo de prova; 
- Pressionar a região do extensômetro colado com o dedo por 2 minutos a uma pressão moderada.

\section{Brasagem dos fios:}

- Brasar os fios do extensômetro no terminal (Terminal L-60, Exel Sensors) conforme a sequência ilustrada nas Figuras 89 e 90;

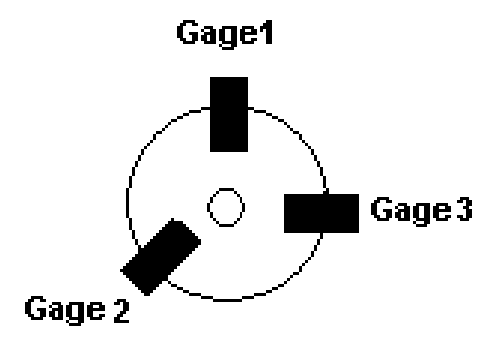

Figura 89. Sequência para brasagem dos fios do extensômetro.

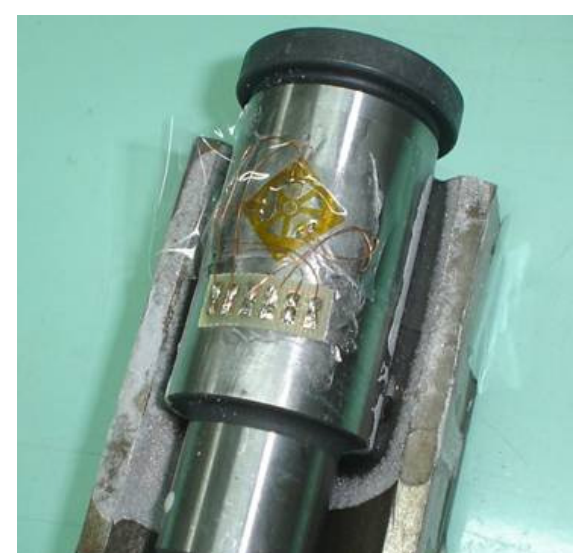

Figura 90. Corpo de prova instrumentado com roseta e respectivos terminais para instrumentação.

- Brasar o cabo 3 x 26 AWG (Cabo Sparflex colado Sn, Metalúrgica Spar) no terminal Figura 91;

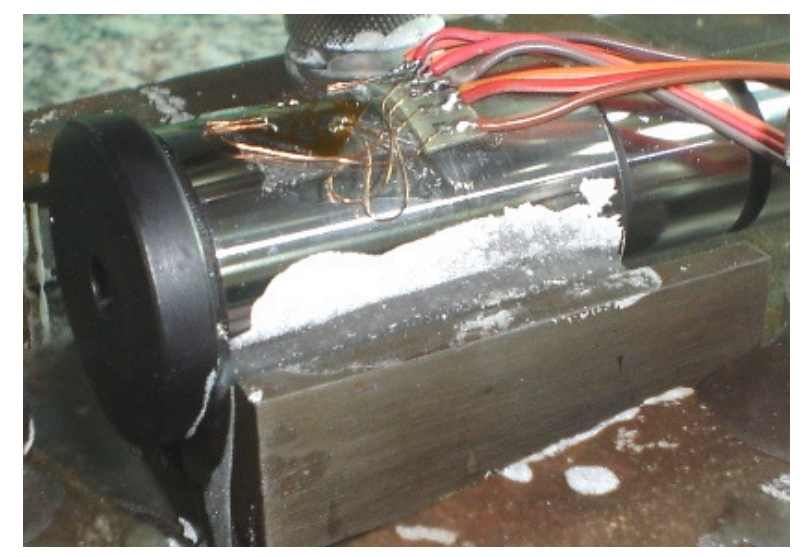

Figura 91. Brasagem dos cabos no terminal. 
Isolamento da instrumentação afim de que o fluido de corte não influencie na leitura das deformações:

- Passar a resina de silicone (RK, Exel Sensors) sobre o extensômetro, fios e terminal. Esperar a cura completa da resina que leva duas horas;

- Colocar uma quantidade generosa de parafina sobre o extremo do cabo soldado ao terminal, com o auxilio de um soprador térmico para que o mesmo modele a parafina sobre a região, afim de que o fluido de corte não influencie na leitura das deformações.

\subsubsection{Montagem do Ensaio do Método do Furo Cego}

- Colar com resina plástica o dispositivo de fixação do corpo de prova em uma placa base e fixar o tripé do equipamento de furação (RS-200, Vishay), Figura 92 ;

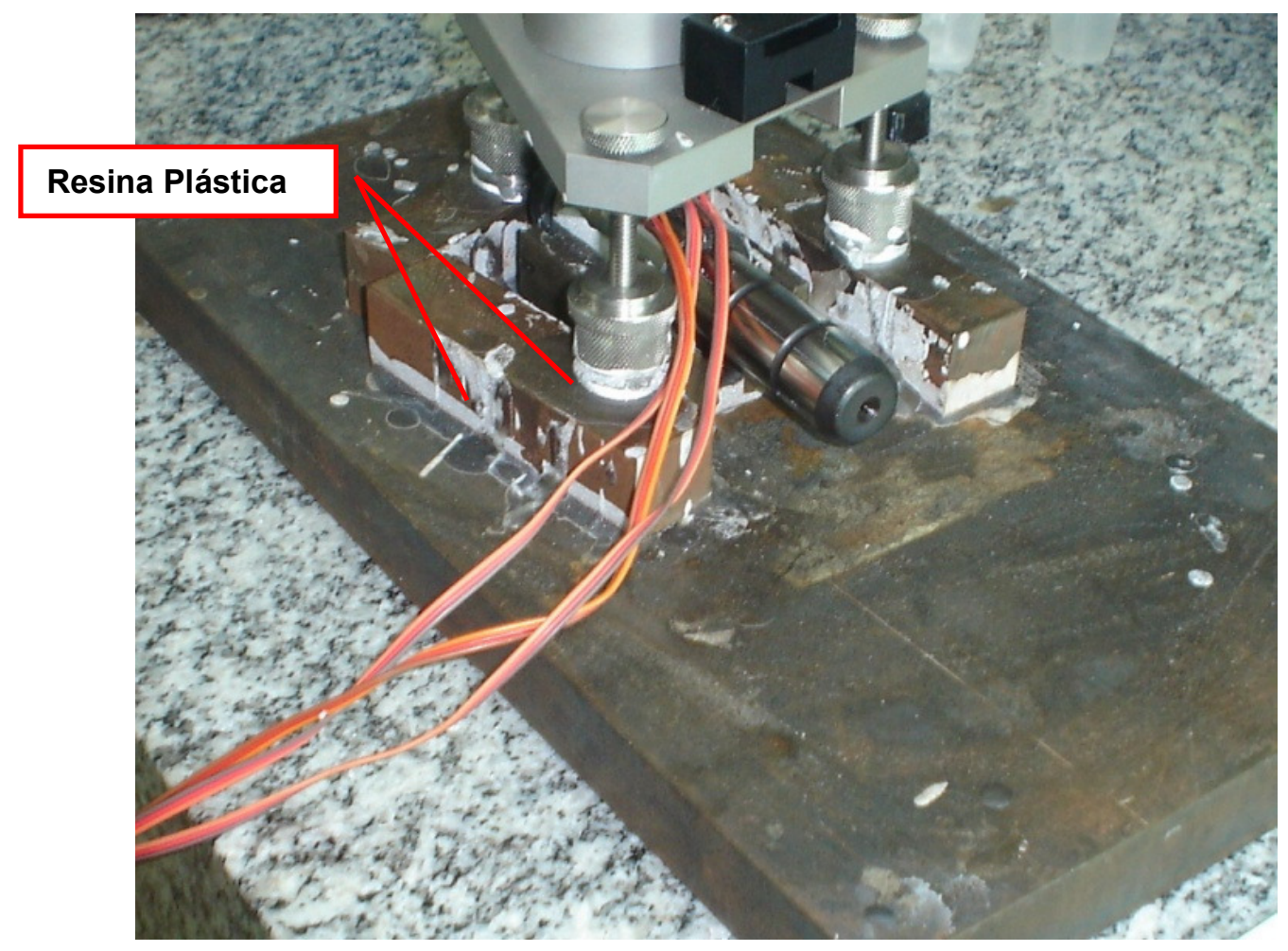

Figura 92. Fixação do corpo de prova e dispositivo com resina plástica.

- Com o auxílio de um microscópio de posicionamento (RS-200, Vishay) localizar o centro da roseta. Deslocar com os parafusos laterais a lente do microscópio até que os eixos graduados do microscópio coincidam com o centro da roseta; 
- Retirar o microscópio e posicionar a turbina pneumática de alta rotação (RS200 / Vishay) com uma fresa de diâmetro 1,8 mm (FG 39, KG Sorensen, metal duro (Wc-Co) sinterizado) no suporte tripé do equipamento.

\subsubsection{Realização do Ensaio do Método do Furo Cego}

Configurando o medidor de deformação (P3, Vishay):

- Selecionar os canais a serem utilizados;

- Ligar os cabos em um quarto de ponte conforme ilustração do equipamento Figura 93;

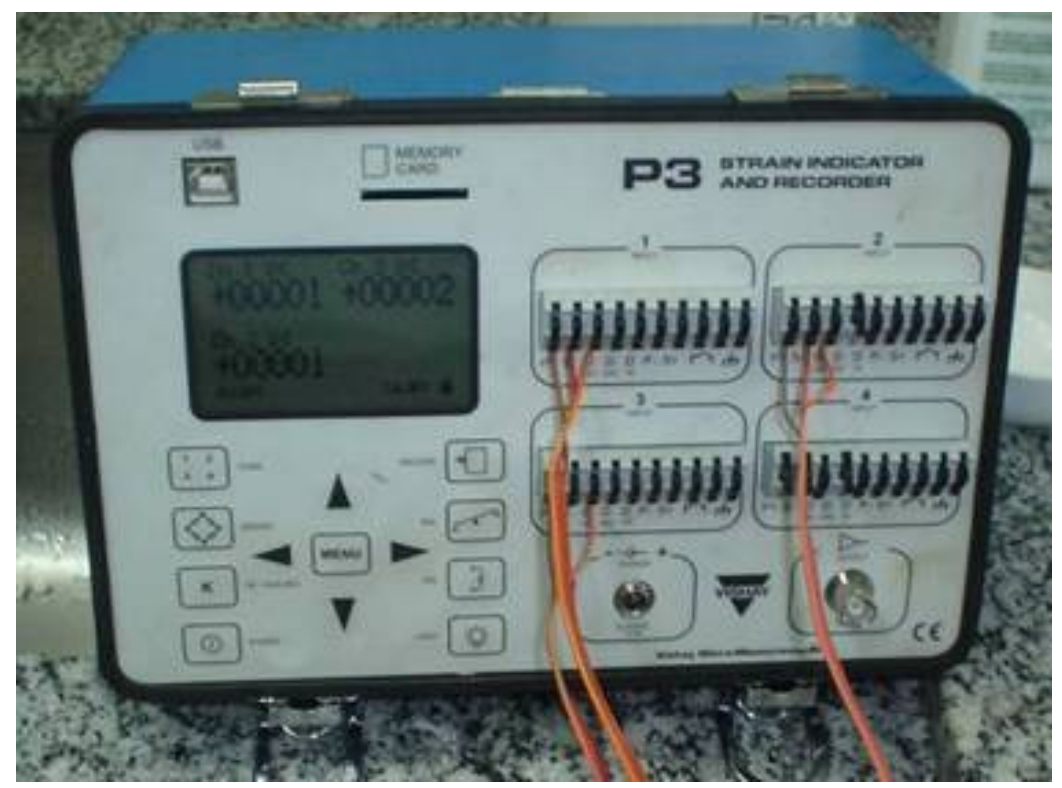

Figura 93. Indicador e gravador de microdeformações modelo P3-Vishay.

- Configurar o equipamento para a leitura de um quarto de ponte de cada canal;

- Configurar o equipamento para realizar as leituras em micro-deformação.

- Zerar todos os canais (Auto-Balance);

- Fazer o posicionamento final da broca sobre o centro da roseta com a turbina em movimento, Figura 94; 


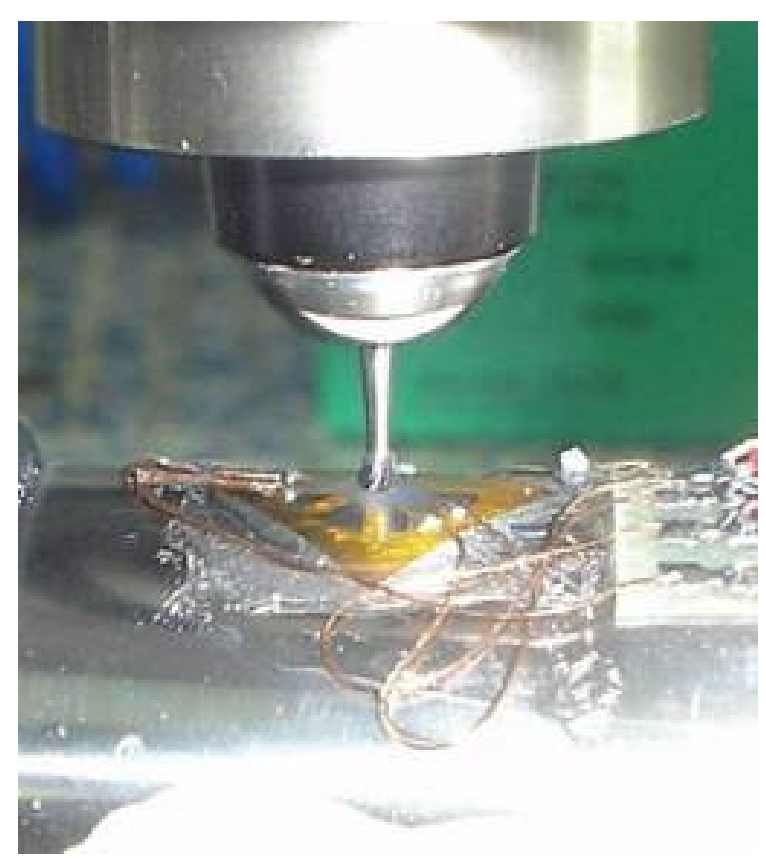

Figura 94. Detalhe da fresa (broca) executando o furo.

- Utilizando um micrômetro e controlando a profundidade de corte, aproximar a broca até a superfície do extensômetro;

- Quando atingir a película do extensômetro parar a turbina e zerar todos os canais do medidor de deformação novamente;

- O ajuste do zero é executado aproximadamente em $20 \mu \mathrm{m}$ abaixo do ponto mais alto da peça. Por se tratar de peça cilíndrica, devemos garantir que a face frontal da broca estará toda em contato e usinando de forma homogênea. Para isto executamos o primeiro toque e descemos $20 \mu \mathrm{m}$ fazemos uma leitura para conferência e zeramos as deformações para dar inicio ao procedimento.

- Furar lentamente controlando a profundidade pelo micrômetro a uma velocidade de penetração de aproximadamente 4 micrometros por minuto (1/5 de linha);

- Realizar o furo aplicando um fluido de corte (Unicort, Unichemicals) com um pincel, fazendo que o ar comprimido espalhe o fluido de corte na região de furação em cada penetração da fresa;

- Controlar a penetração a cada $20 \mu \mathrm{m}$ e anotar os valores de deformação, mostrados no medidor de deformação criando uma planilha dos resultados encontrados; 
- Realizar o ciclo acima a cada $20 \mu \mathrm{m}$ e continuar a furação até a profundidade de $0,2 \mathrm{~mm}$.

A Figura 95 apresenta a visão geral do equipamento utilizado para usinagem do furo e coleta dos valores de deformação.

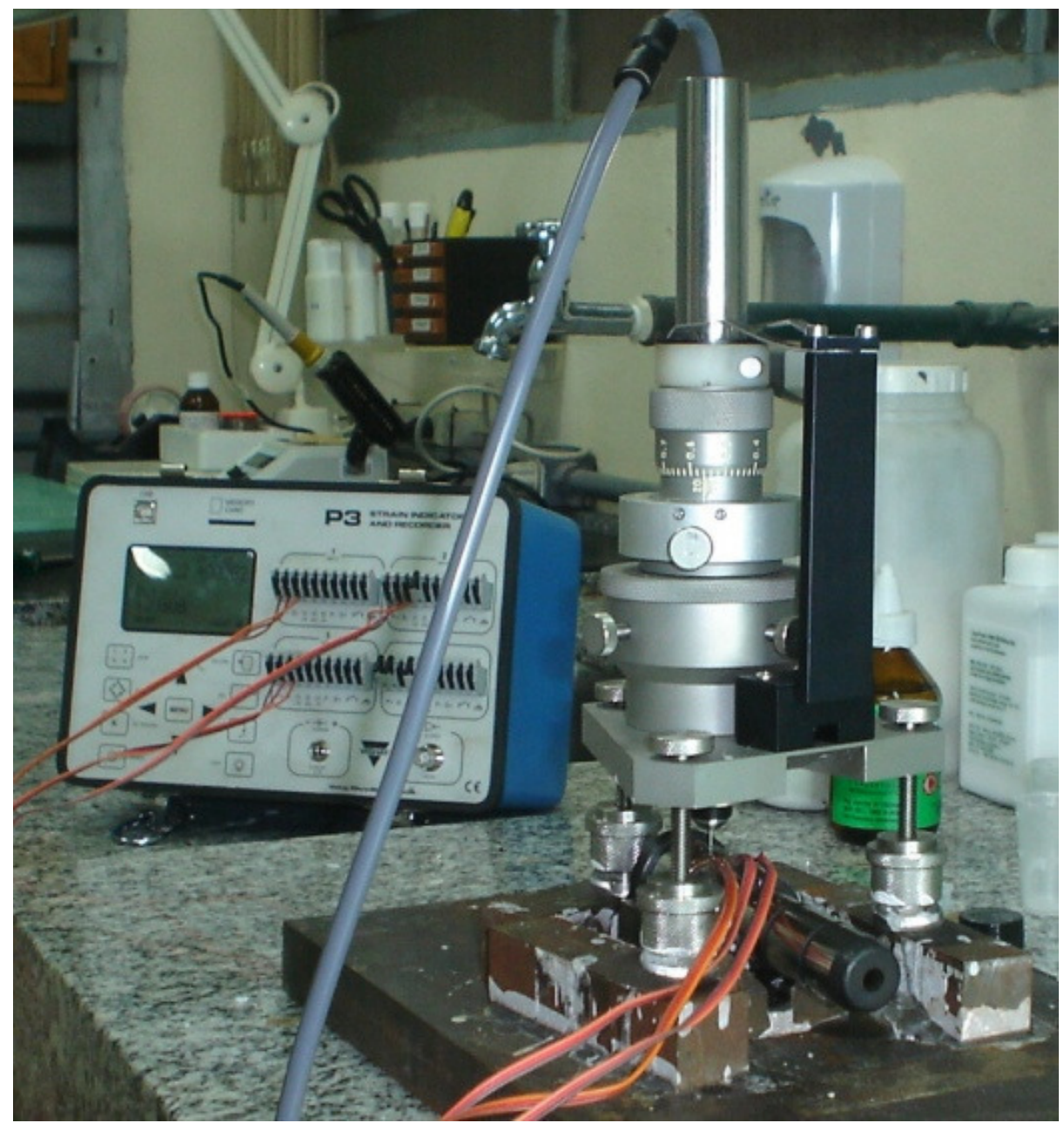

Figura 95. Montagem utilizada para usinagem do furo e coleta dos valores de deformação.

Os dados de deformação da planilha foram então inseridos no software H-Drill (Vishay), para analise por meio do método integral que resultou nos gráficos de tensão para o sentido circunferencial e axial Figura 96. 


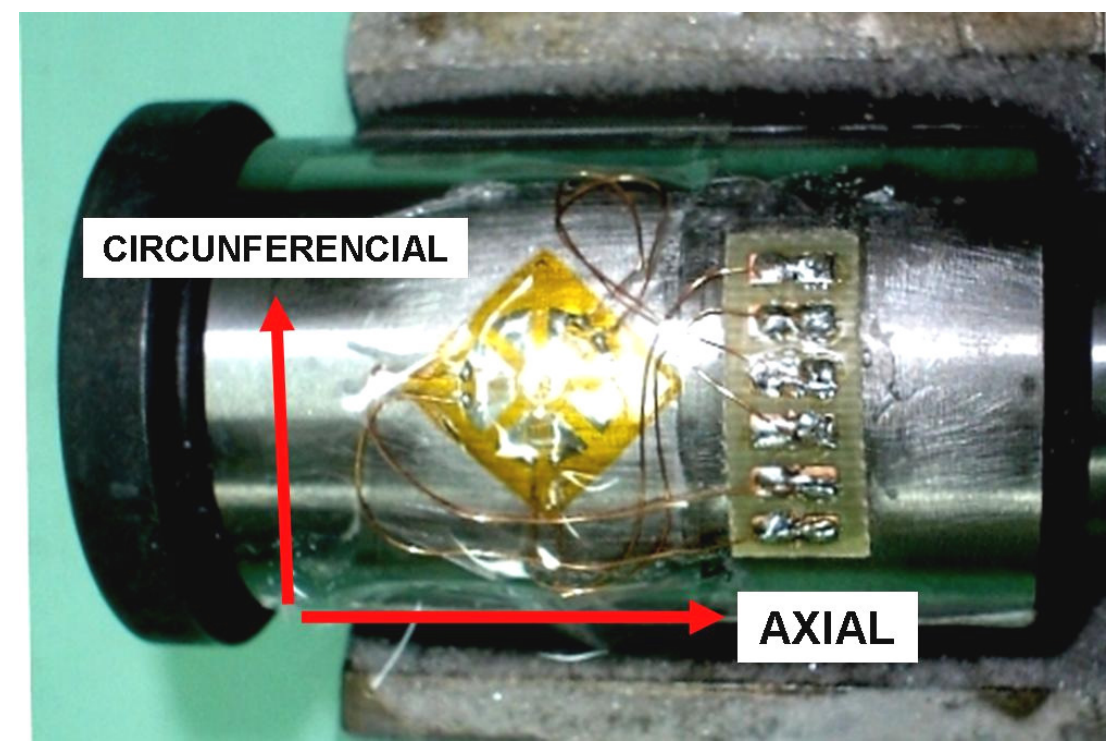

Figura 96. Indicação dos sentidos de leitura da tensões.

\subsection{Tensão Residual Superficial por Difração de Raios-X}

Devido ao fato do procedimento do método do furo cego não apresentar boa resolução nas leituras imediatamente superficiais à amostra (fato observado no procedimento de zeramento do equipamento, vide procedimento no item 3.3.3), adotou-se analisar as tensões superficiais pelo método da difração de raios-X.

Para levantamento das tensões residuais superficiais foi utilizado um Difratômetro de Raios-X, marca RIGAKU - DMAX Rint 2000. O método utilizado nas medições foi o do $\operatorname{sen}^{2} \psi$ com variação do $\psi$ de $-60^{\circ}$ a $+60^{\circ}$, de $10 \mathrm{em} 10^{\circ}$, Tubo de

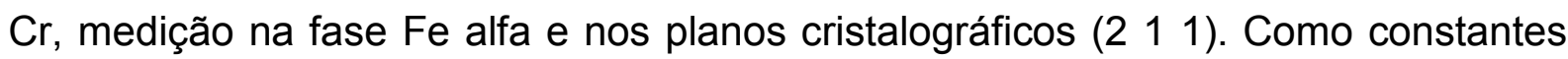
elásticas de material foram utilizadas $E=210.000 \mathrm{MPa}$ e $v=0,29$. As tensões foram medidas no sentido circunferencial, isto é na direção tangencial à força de corte. A Figura 97 apresenta o equipamento utilizado. 


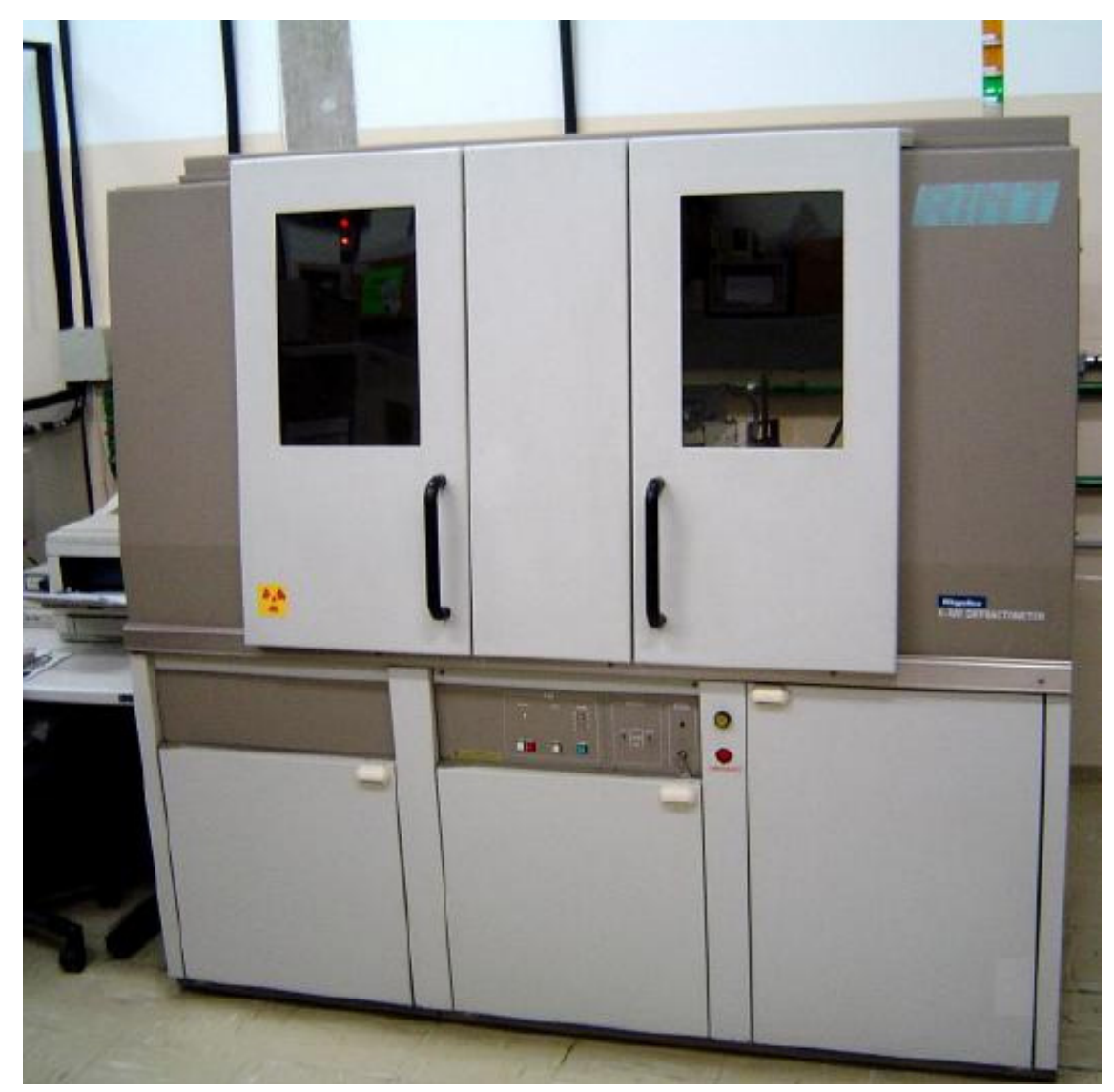

Figura 97. Difratômetro de Raios-X, marca RIGAKU - DMAX Rint 2000.

Para análise das tensões residuais foi utilizada uma amostra para cada condição de torneamento em material endurecido efetuada, portanto seis amostras usinadas foram analisadas. Em cada amostra foram efetuadas três medições visando trabalhar com a média dos valores encontrados e assim minimizar erros de leituras.

\subsection{Aquisição de Dados da Topografia Superficial 3-D}

Para aquisição dos dados da topografia superficial 3-D foi empregado um interferômetro laser Microfocus Expert IV, da UBM Corporation, Figura 98 e Figura 99. 


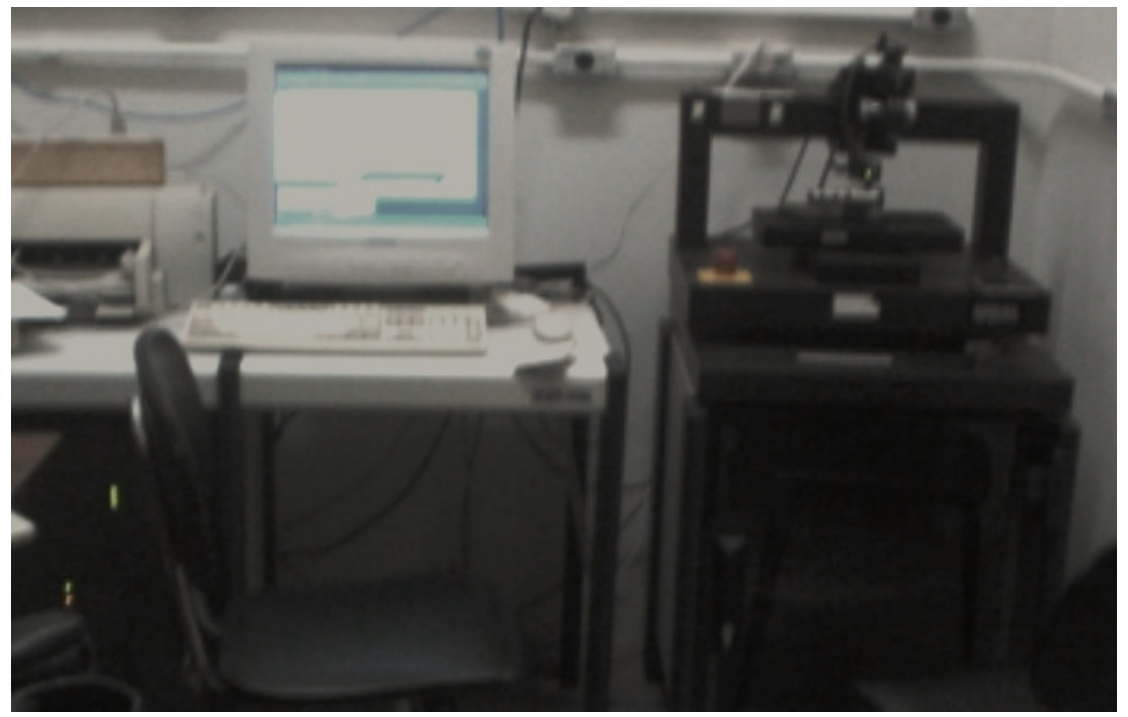

Figura 98. Equipamento de Interferometria laser utilizado para a medição de topografia 3-D.

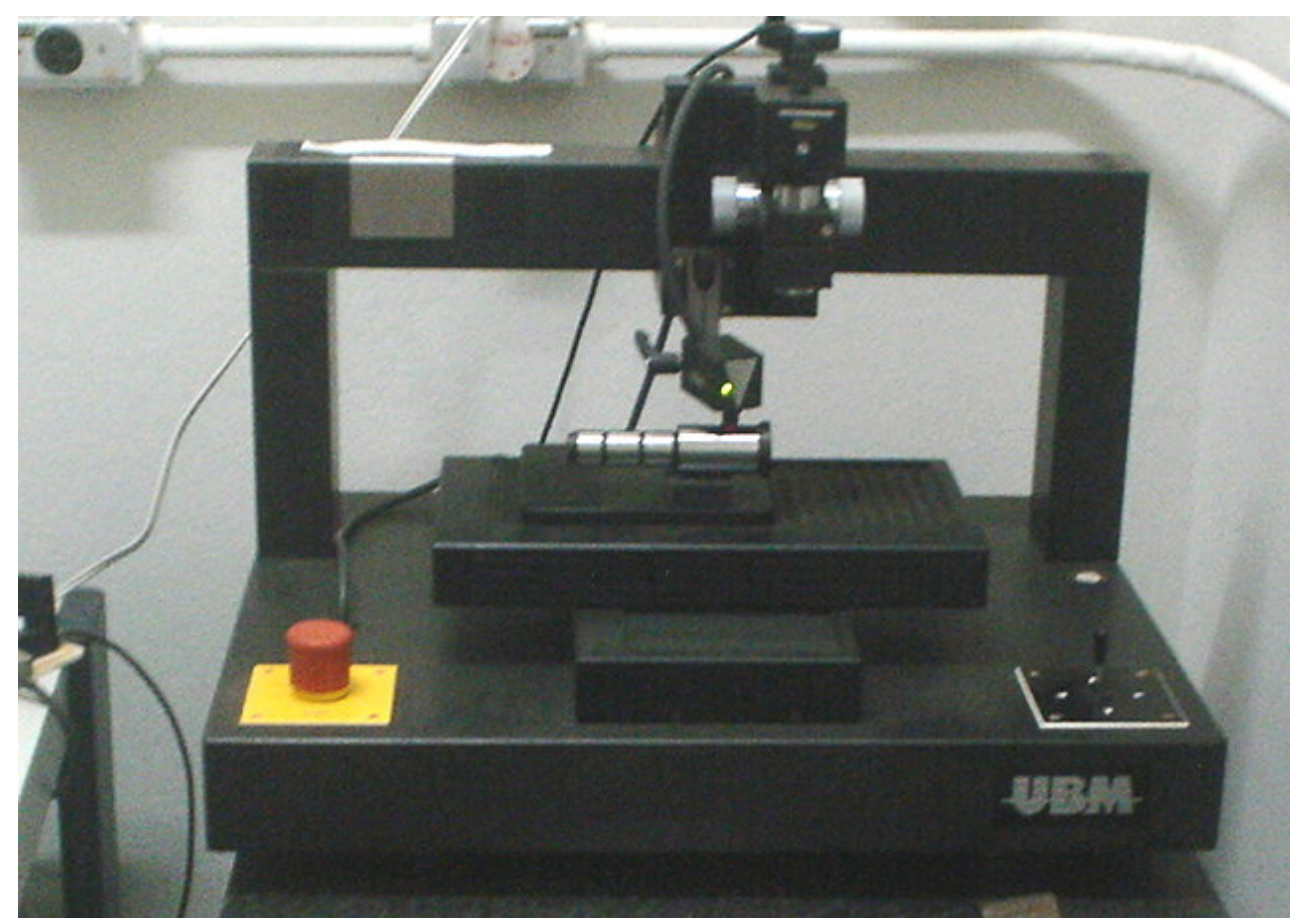

Figura 99. Interferômetro laser utilizado para a medição de topografia 3-D.

\subsubsection{Procedimento do Mapeamento da Superfície 3-D}

As peças foram apoiadas na mesa do equipamento por um bloco em "V" e fixadas com fita adesiva para evitar vibrações decorrentes das movimentações da mesa do equipamento, como evidenciado na Figura 100. 
Para o mapeamento da área da superfície foram adotados os seguintes parâmetros para a taxa de deslocamento da mesa controlada, esta taxa reflete a quantidade de pontos adquiridos para composição da superfície 3-D:

- Taxa de movimento/aquisição no sentido do eixo X: 1000 pontos por milímetro;

- Taxa de movimento/aquisição no sentido do eixo Y: 50 linhas por milímetro;

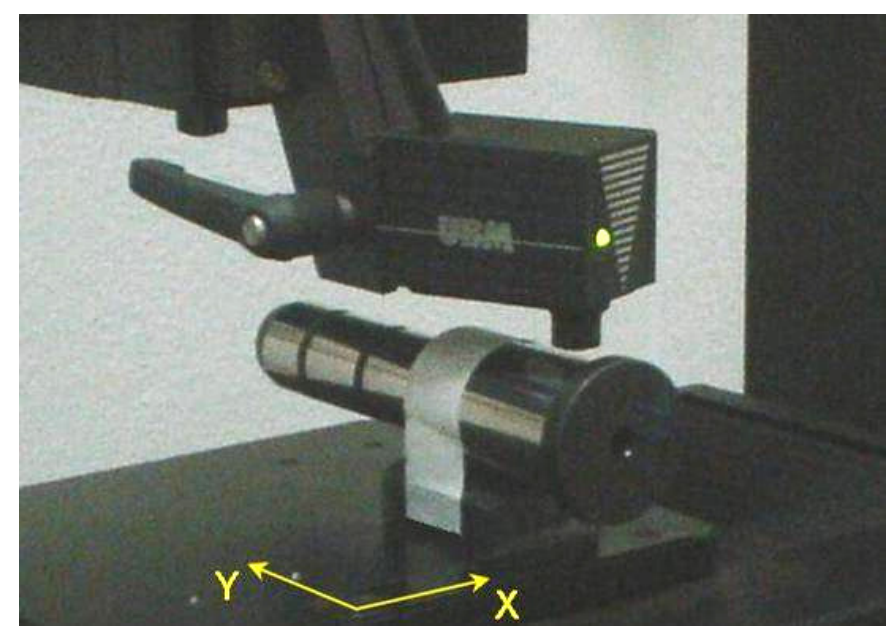

Figura 100. Medição de um corpo de prova com interferômetro laser.

Os dados foram processados e armazenados pelo software residente do equipamento para posterior análise, Figura 101.

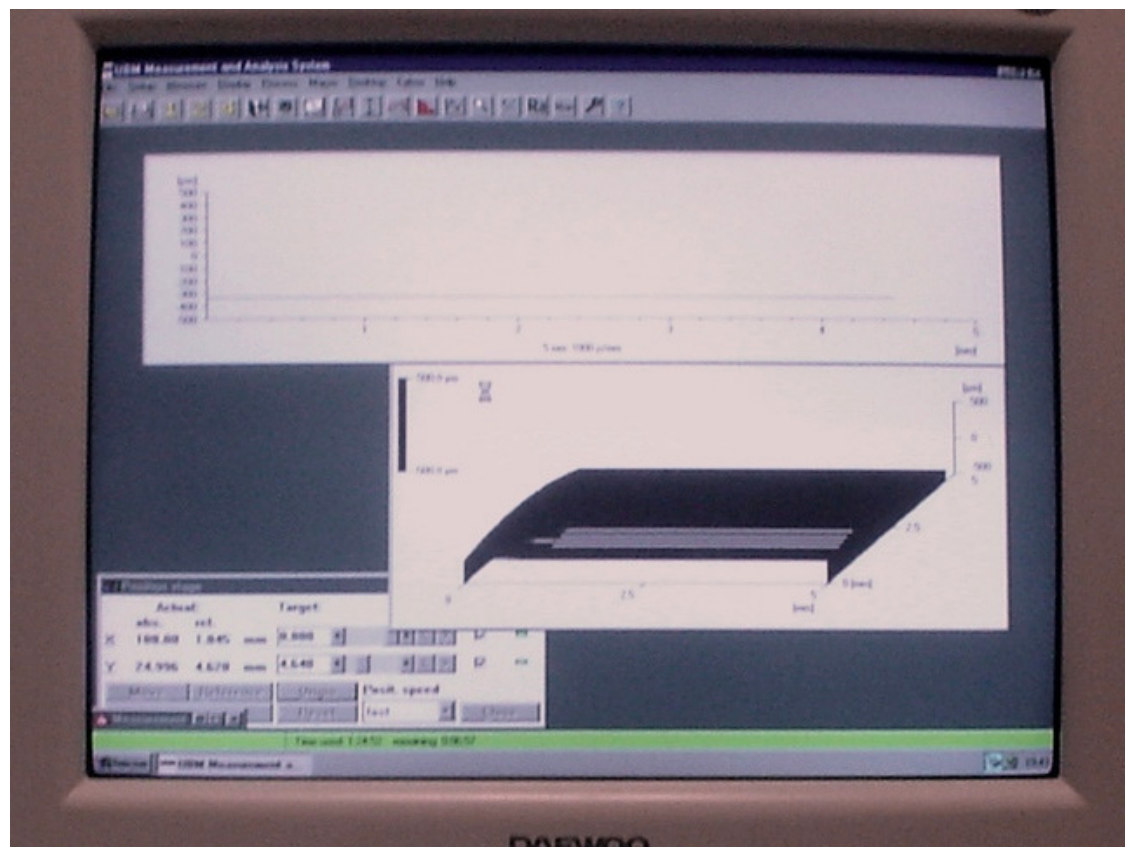

Figura 101. Software de aquisição de dados acoplado ao Interferômetro laser utilizado para a medição de topografia 3-D (UBM Measurement and Analysis System). 
Após a aquisição dos dados das topografias 3-D de todas as amostras estas foram pós-processados e analisados com o auxílio do software Mountains Map Universal versão 3.1 .9 (versão Demo) da empresa Digital Surf. A Figura 102 apresenta um fluxo do tratamento dado a todos os dados antes de ser efetuada a leitura dos valores dos parâmetros de superfície em questão.

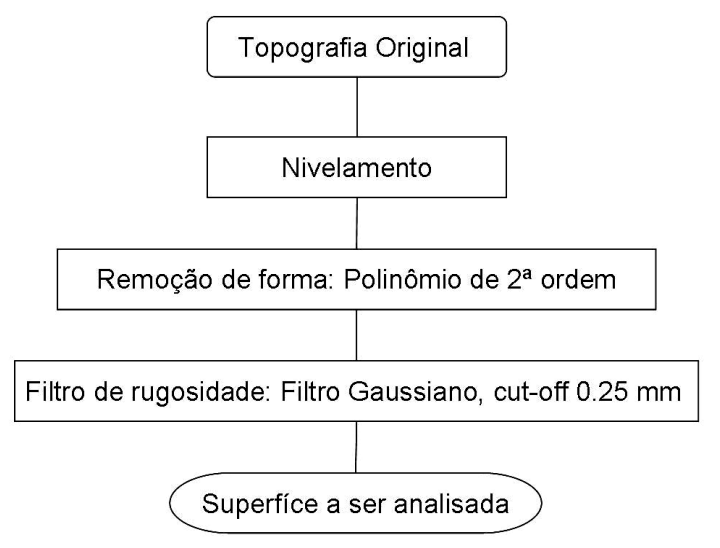

Figura 102. Fluxo do tratamento efetuado em cada topografia 3-D antes de tomada de valores.

A Figura 103 apresenta a tela do programa Mountains Map executando a análise em uma das amostras torneadas, os dados assim obtidos foram digitados em planilha que se encontram no Anexo-E.

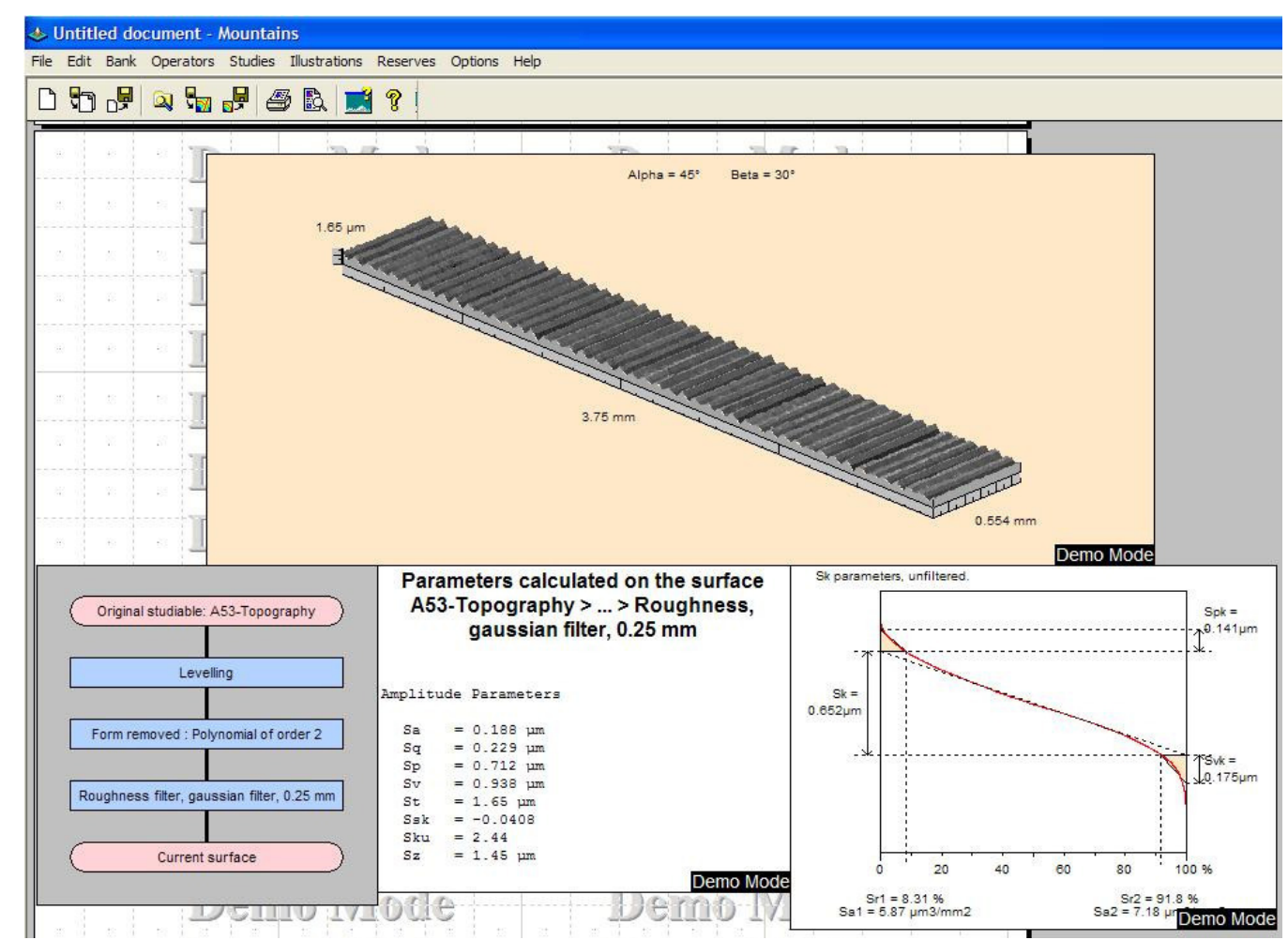

Figura 103. Tela do software Mountains Map versão 3.1.9 (versão Demo)- empresa Digital Surf. 


\subsection{Preparação Metalográfica}

Para as análises metalográficas dos corpos de prova foram preparadas seis amostras embutidas em baquelite, Figura 104. Um corte transversal no sentido radial do corpo de provas foi executado, e uma amostra da região limítrofe da camada superficial foi destacada para análise. A Figura 104 (a) apresenta uma amostra somente polida e a Figura 104 (b) apresenta uma amostra com ataque nital de 3\%.

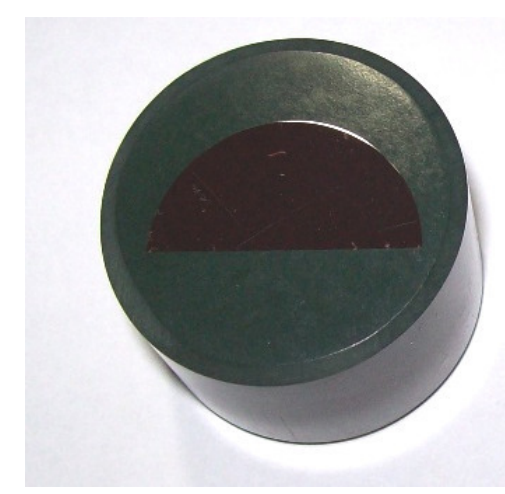

a)

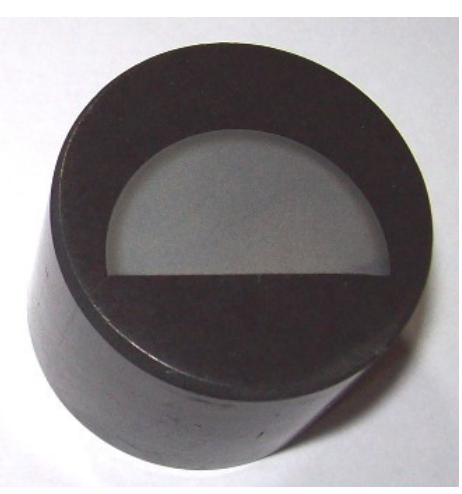

b)

Figura 104. Amostras embutidas em baquelite, a) Somente polida, b) Com ataque nital de $3 \%$.

\subsection{Análise no Microscópio de Varredura Eletrônica MEV}

Para análise no Microscópio eletrônico de varredura (MEV) as amostras foram embutidas em baquelite e juntamente com um calço de material qualquer visando prover um melhor apoio no momento do polimento. Este procedimento evita 0 arredondamento das bordas externas do corpo de prova.

O equipamento utilizado foi o Microscópio eletrônico de varredura Stereoscan LEO 440, Figura 105, com detectores de elétrons secundários e retroespalhados, catodoluminescência e corrente de amostra. Acoplado a sistemas de microanalise química por EDS e WDS, OXFORD Isis (EDS) integrado com Microspec 600i (WDS). Para obter condutividade no material em análise uma fita de carbono foi colada na região do material a ser analisado como mostra a Figura 106. 


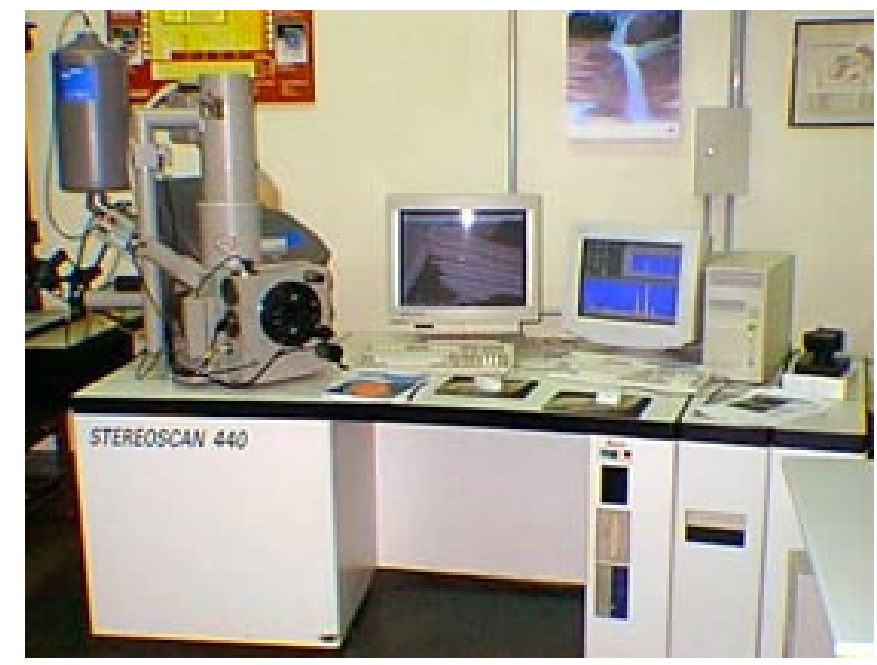

Figura 105. Microscópio eletrônico de varredura LEO 440.

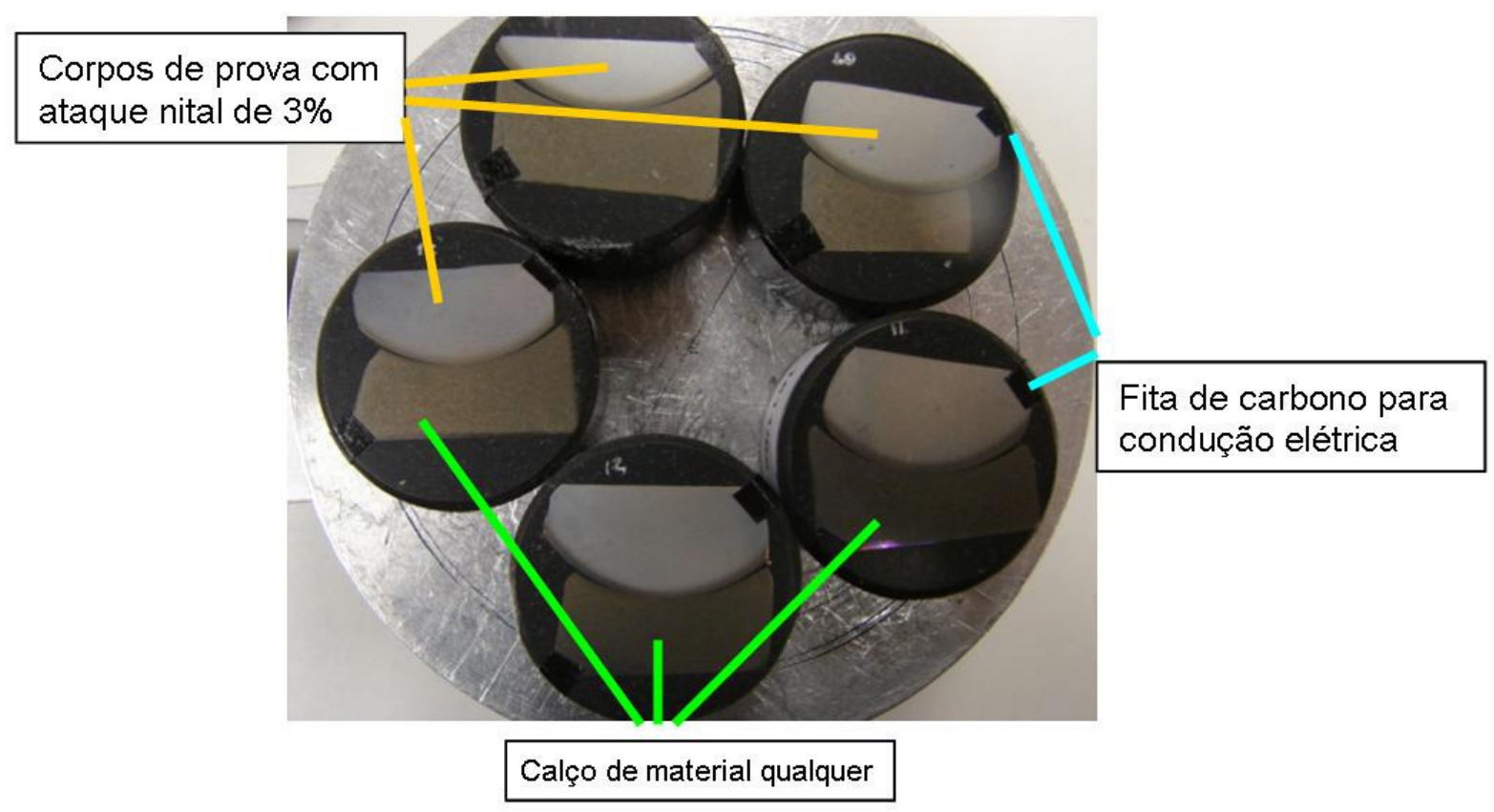

Figura 106. Amostras embutidas em baquelite preparadas para o MEV.

\subsection{Análise de Dureza por Microendentação}

As medições de microdureza foram executadas com um microdurômetro HMVShimadzu (HVM-2 344-04152-02 - Figura 107), utilizando carga de 0,49 N (0,05 kgf) durante $15 \mathrm{~s}$ em todas as medições. As medições foram executadas na escala Vickers (HV). 
As medições se iniciaram na interface corpo de prova/baquelite e progrediram em direção ao centro do corpo de prova, visando a obtenção de um perfil de dureza.

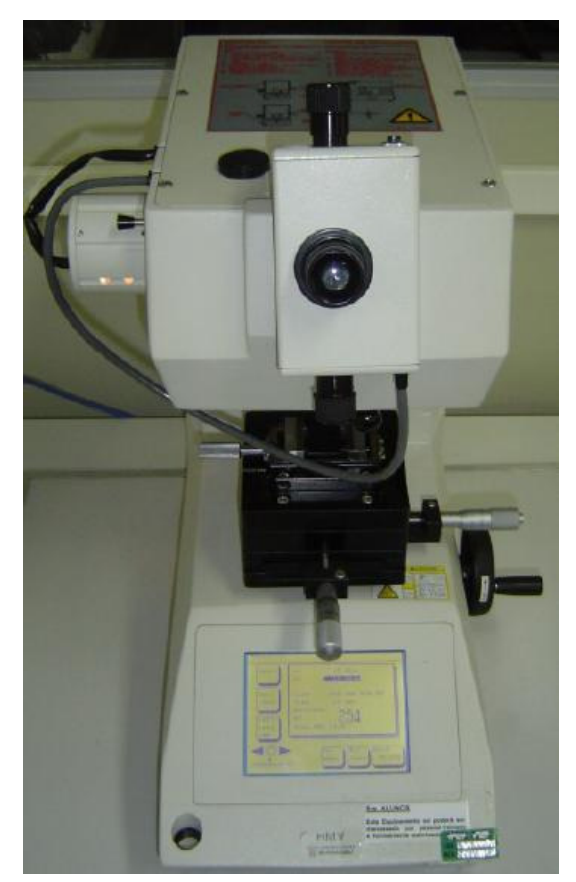

Figura 107. Micro-durômetro HMV - Shimadzu HVM-2 344.

Um espaçamento de $40 \mu \mathrm{m}$ foi utilizado entre cada endentação de medição, visando não causar erros de sobreposições. Para obter um perfil mais preciso, foi executada uma segunda medição defasada lateralmente de $40 \mu \mathrm{m}$ no sentido vertical e $20 \mu \mathrm{m}$ no sentido horizontal, gerando assim leituras de dureza a cada $20 \mu \mathrm{m}$ de profundidade conforme mostra a Figura 108.

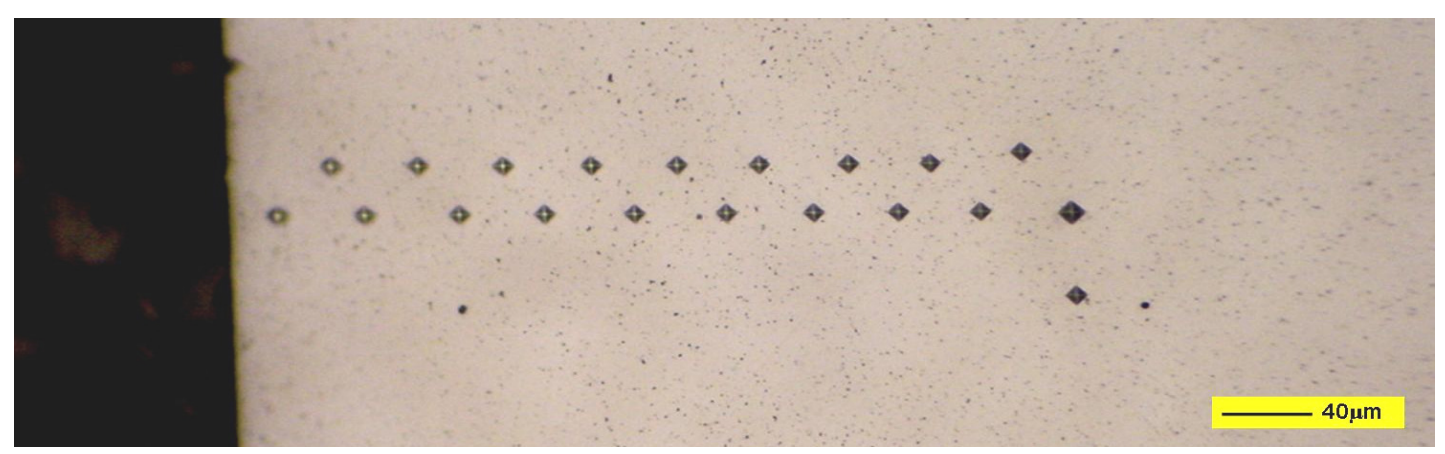

Figura 108. Medição de dureza efetuada nas amostras. 


\section{RESULTADOS DO EXPERIMENTO}

\subsection{Caracterização do Perfil de Tensão Residual}

As Figuras 109 e 110 apresentam respectivamente o resultado gráfico da análise do perfil de tensão residual axial e circunferencial obtidos em função da combinação da velocidade de corte e avanços utilizados no experimento. $O$ levantamento do perfil de tensões residuais foi executado com o método do furo cego. Para cada condição de velocidade de corte e avanço um corpo de prova foi analisado. O resultado foi registrado em planilha que se encontra no Anexo-B.

\section{Profundidade}

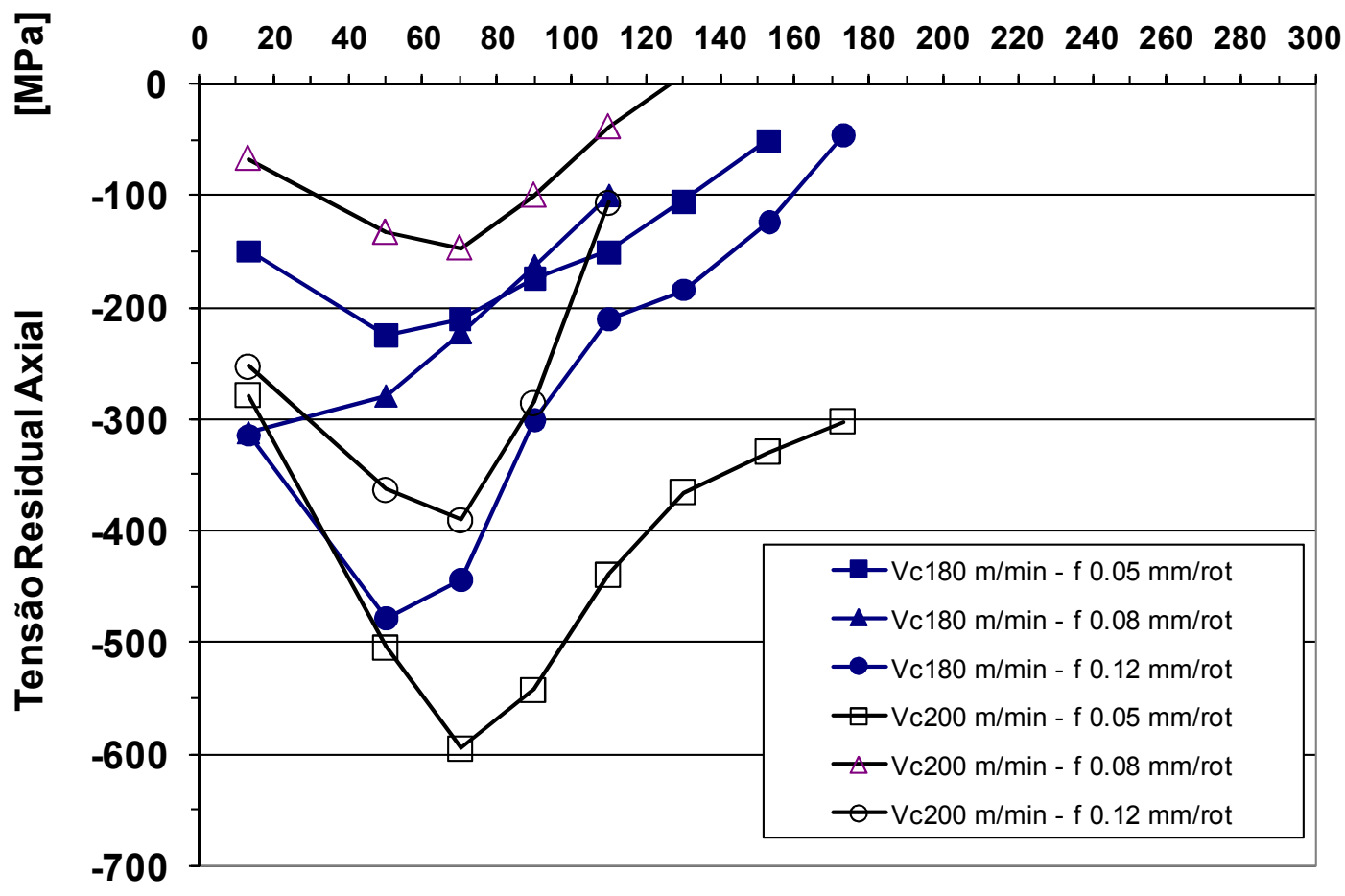

Figura 109. Perfil de Tensão Residual Axial para condição de torneamento em material endurecido. 
Profundidade

$[\mu \mathrm{m}]$

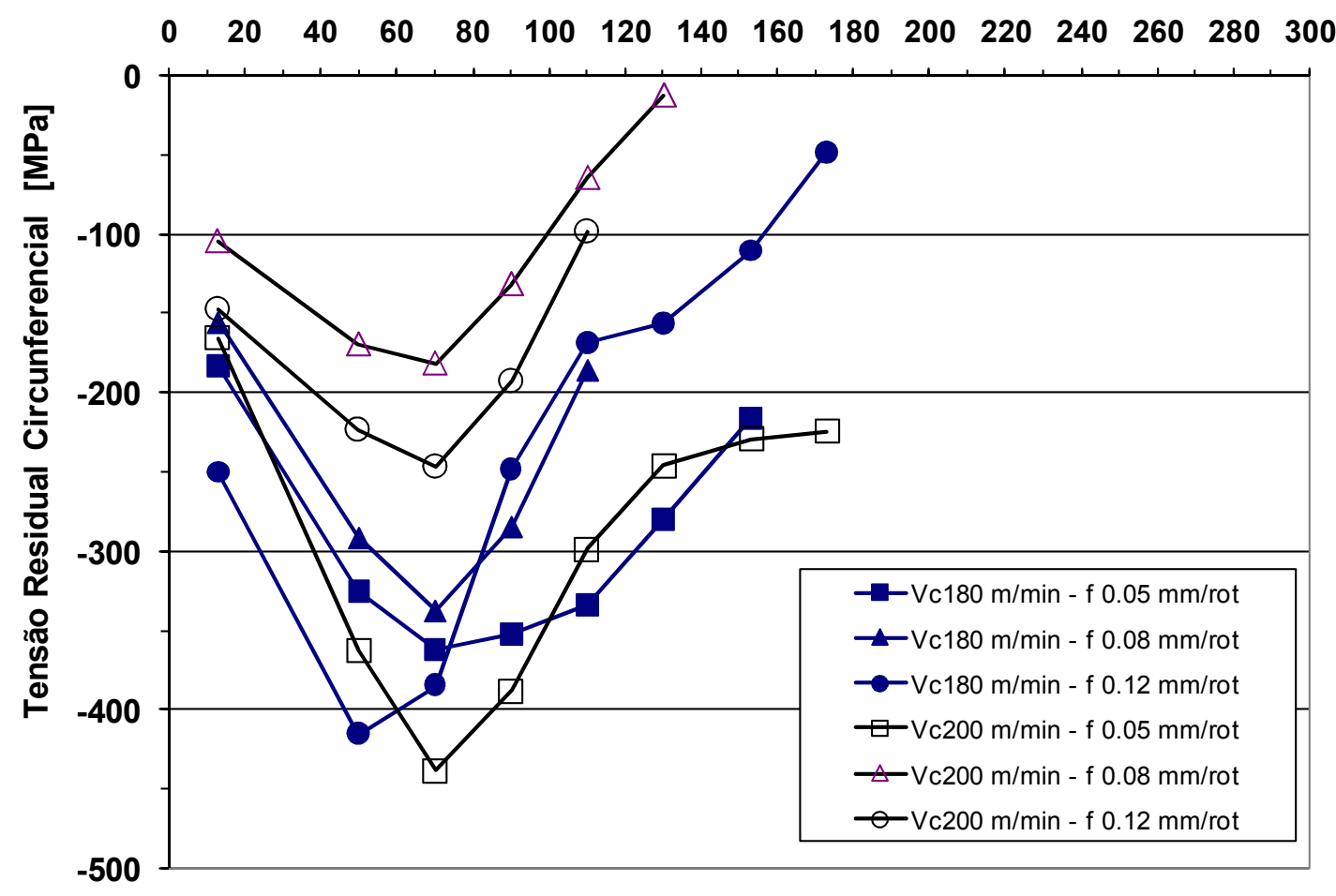

Figura 110. Perfil de Tensão Residual Circunferencial para condição de torneamento em material endurecido.

Nota-se grande dispersão nos resultados apresentados nas Figuras 109 e 110, porém todos os valores encontrados são de tensão residual de compressão.

Uma possível causa para esta dispersão é que a energia envolvida no processo devido ao calor e deformação, gerados pelo par velocidade de corte e avanço, não são dimensionadas neste trabalho.

A medição de tensões residuais pelo método do furo cego, em materiais endurecidos, é muito dependente da execução correta e criteriosa dos procedimentos de preparação do equipamento e execução do furo. Uma vez que estamos lidando com um material que possui uma dureza próxima da dureza da broca utilizada no equipamento, a usinagem do furo se torna de difícil execução. É importante que seja executada sempre pela mesma pessoa, visando minimizar que os erros de procedimentos sejam somados aos resultados.

Deve ser notado também que as leituras são apresentadas partindo da profundidade de $10 \mu \mathrm{m}$, pois o método exige o zeramento do equipamento na face da peça, os valores encontrados nesta região não são confiáveis devendo ser descartados. 
Para verificação da quantidade de tensão induzida pelo evento de torneamento endurecido, uma amostra na condição prévia ao torneamento foi analisada pelo mesmo método do furo cego, a peça encontrava-se na condição cementada, temperada e revenida. A Figura 111 e Figura 112 apresentam o perfil de tensão residual encontrado para esta condição.

Observa-se nas Figuras 111 e 112 que a superfície do material encontrava-se com tensão residual de tração e após o torneamento esta tensão se converteu para o estado de tensão residual de compressão.

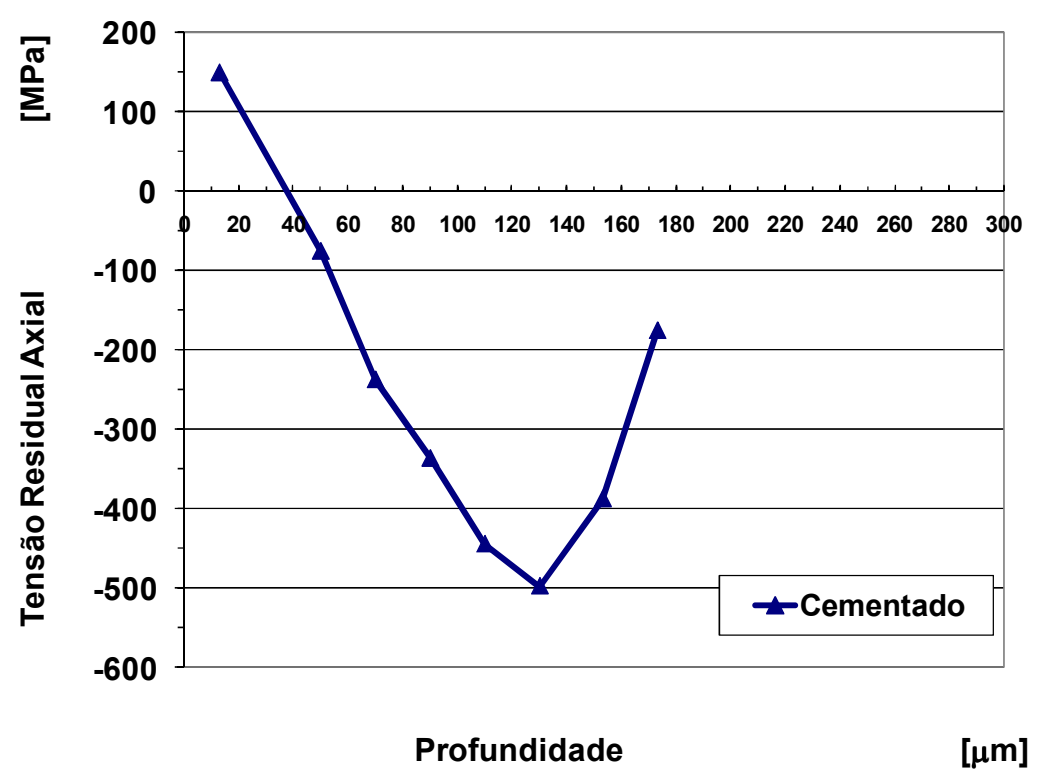

Figura 111. Perfil de Tensão Residual Axial da amostra cementada.

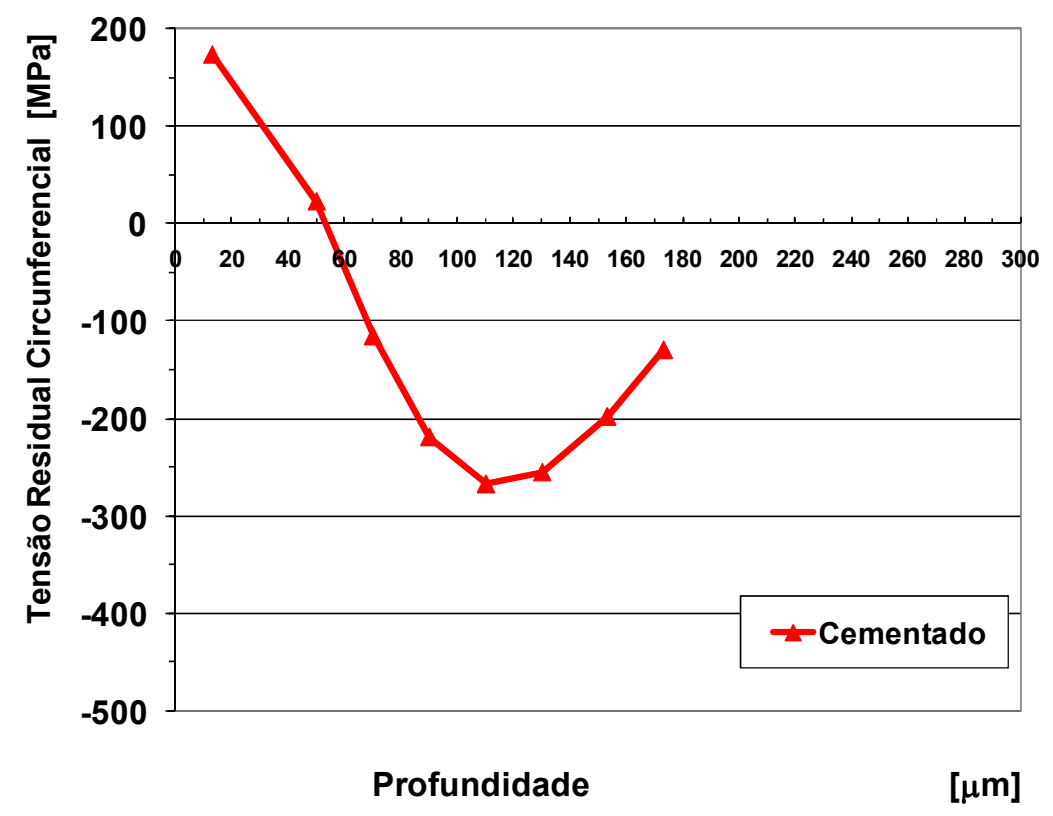

Figura 112. Perfil de Tensão Residual Circunferencial da amostra cementada. 
Adicionalmente uma peça usinada em condições convencionais de retificação (processo original utilizado para usinagem de acabamento deste componente) também foi analisada, Figura 113 e Figura 114, para levantamento de comparações entre os processos. Embora a condição de tensão residual seja de compressão seu valor é menor quando comparado ao processo de torneamento. Outras amostras com condições de retificação diferenciadas não foram exploradas, pois a amostra analisada foi retificada em condições já aprovadas para sua produção pelo processo de retificação (isto inclui outros aspectos como rugosidade superficial).

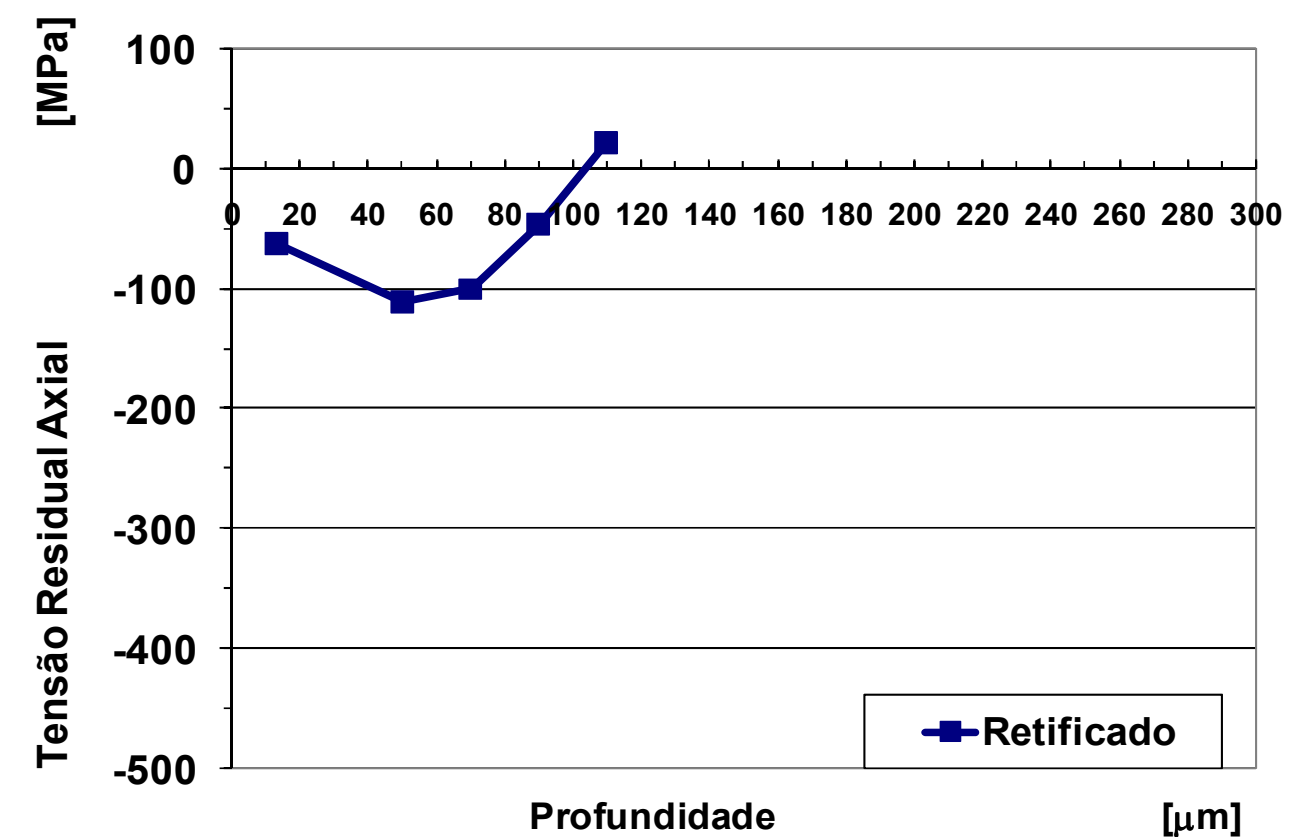

Figura 113. Perfil de Tensão Residual Axial da amostra retificada.

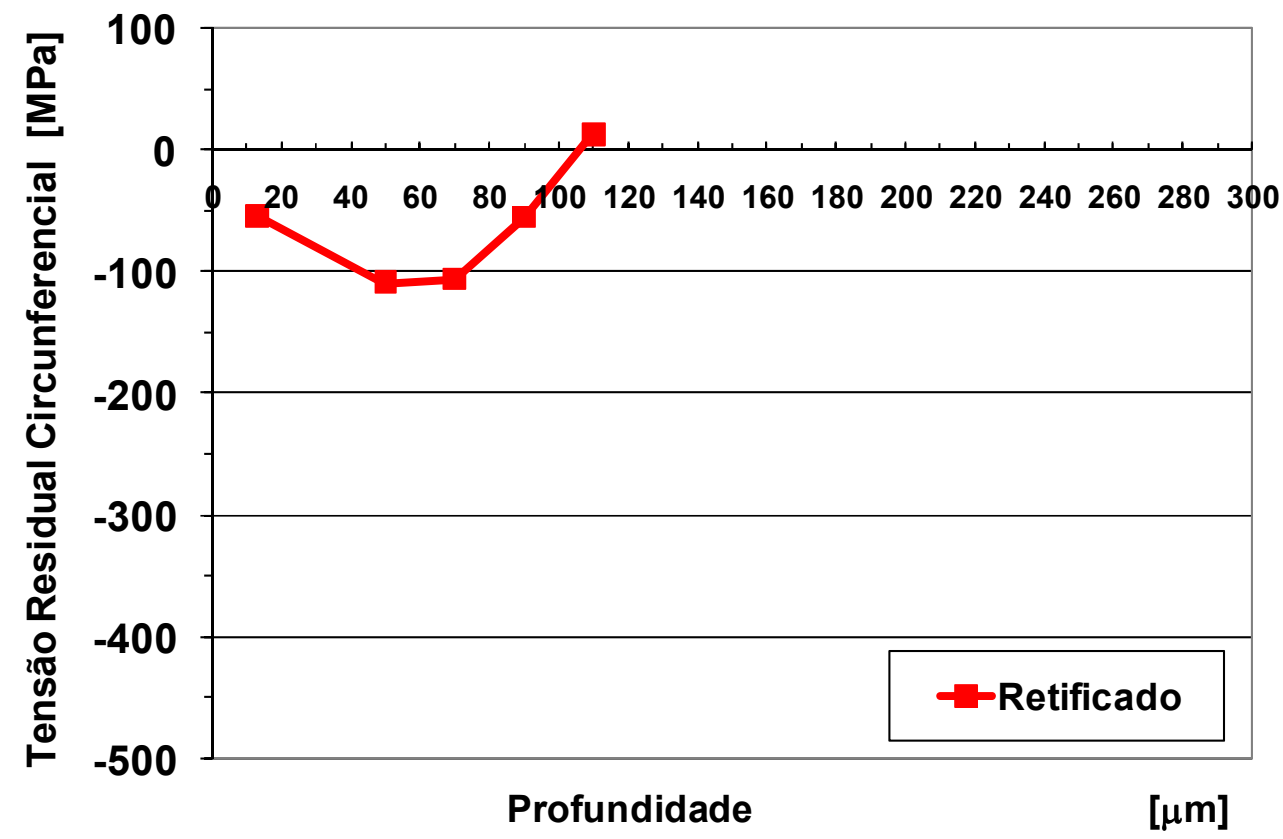

Figura 114. Perfil de Tensão Residual Circunferencial da amostra retificada. 


\subsection{Caracterização da Tensão Residual Superficial}

A Figura 115 apresenta o resultado gráfico da análise da tensão residual circunferencial superficial, obtido em função do par Velocidade de corte e avanço utilizados no experimento. Para cada condição de velocidade de corte e avanço um corpo de prova foi analisado, e cada análise constituiu-se de medição em três regiões distintas, a Figura 115 apresenta a média dos resultados para cada corpo de prova. A planilha com os valores encontram-se no Anexo-C.

Nota-se uma grande dispersão para os resultados, apresentada pelas barras de intervalo de confiança a 95\%. A medição por raios-X é sensível à condição de textura da superfície, ou seja, a rugosidade pode ser uma fonte de erros e de dispersão observados nos resultados. Outro fato a ser observado, é que a medição foi executada somente no sentido circunferencial, a medição do sentido axial poderia apresentar outros valores que ajudariam a entender melhor os resultados.

Apesar da dispersão observada todos os valores se encontram na faixa de tensão residual de compressão.

\section{Tensão Residual Superficial Circunferencial}

95\% de IC para média nas barras

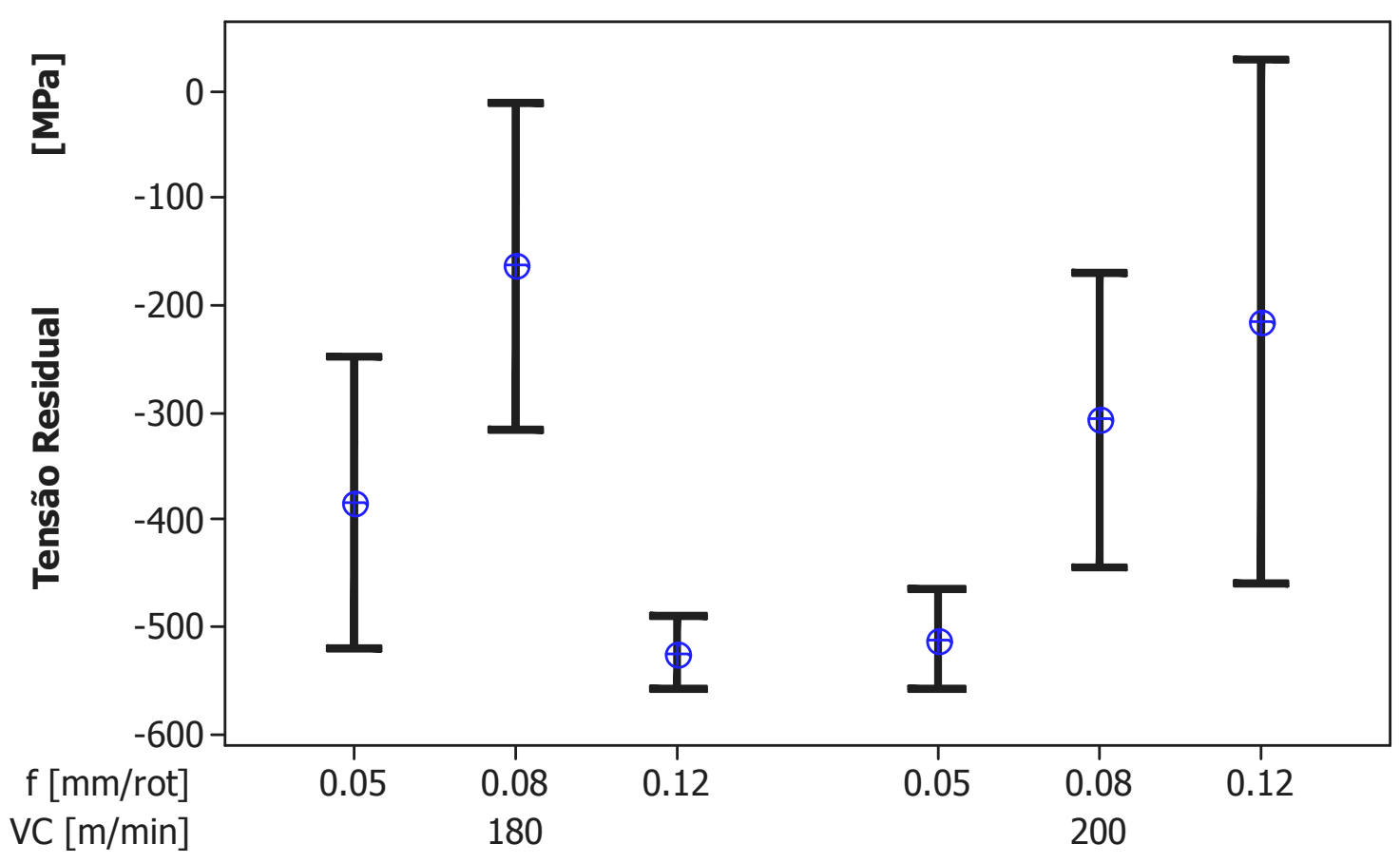

Figura 115. Tensão Residual Circunferencial na superfície das amostras. 


\subsection{Caracterização da Topografia Superficial 3-D}

As topografias 3-D das peças usinadas nas condições do ensaio são apresentadas nas Figuras 116 a 121. O mapeamento 3-D das superfícies revela uma natureza anisotrópica comum para o processo de torneamento. Devido à característica do corte com aresta única, a superfície é composta por picos e vales bem definidos.

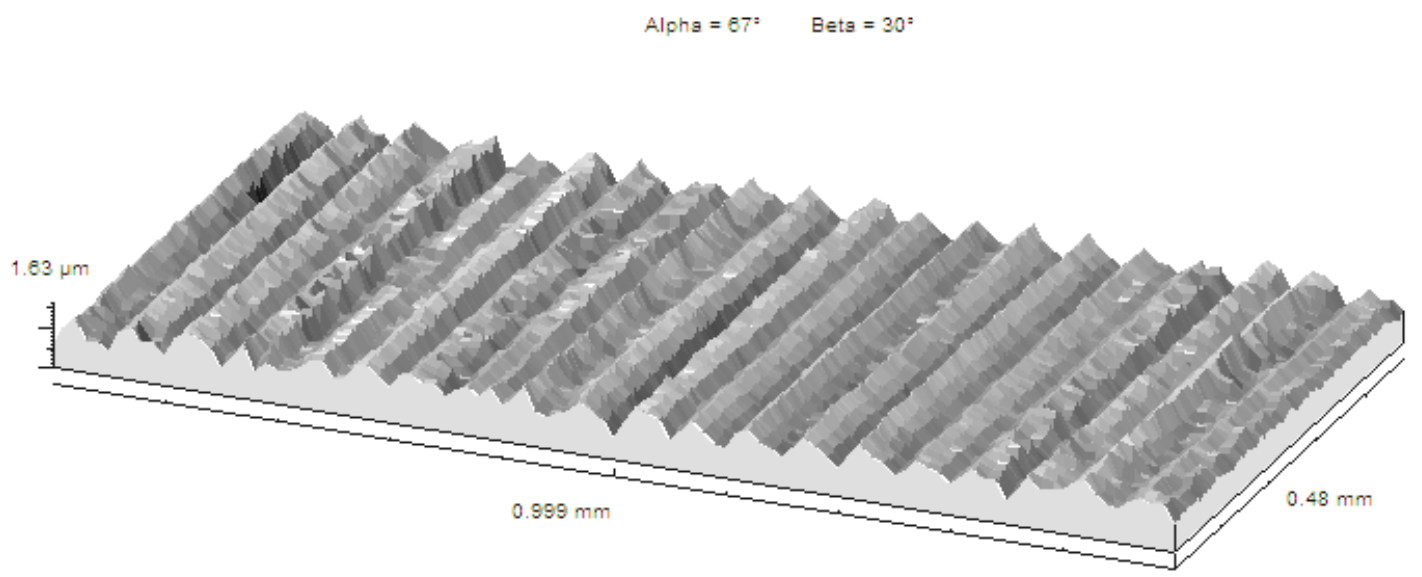

Figura 116. Topografia da superfície usinada com Velocidade de Corte $180 \mathrm{~m} / \mathrm{min}$ e Avanço 0,05 $\mathrm{mm} / \mathrm{rot}$.

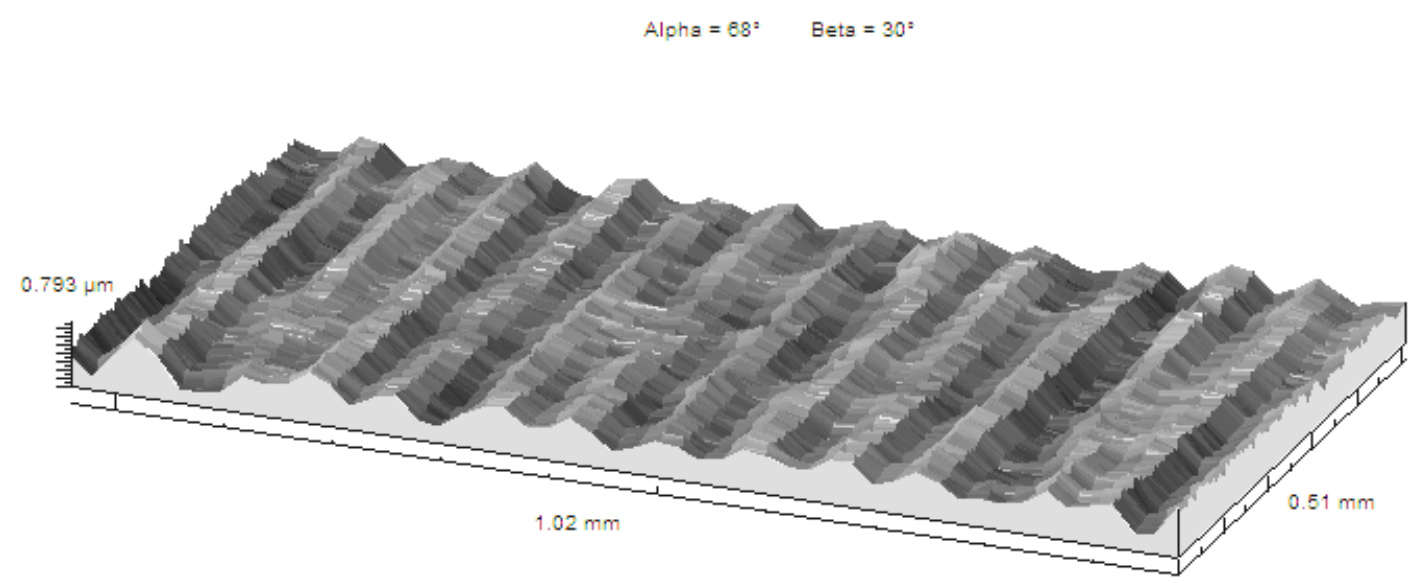

Figura 117. Topografia da superfície usinada com Velocidade de Corte $180 \mathrm{~m} / \mathrm{min}$ e Avanço 0,08 $\mathrm{mm} / \mathrm{rot}$. 


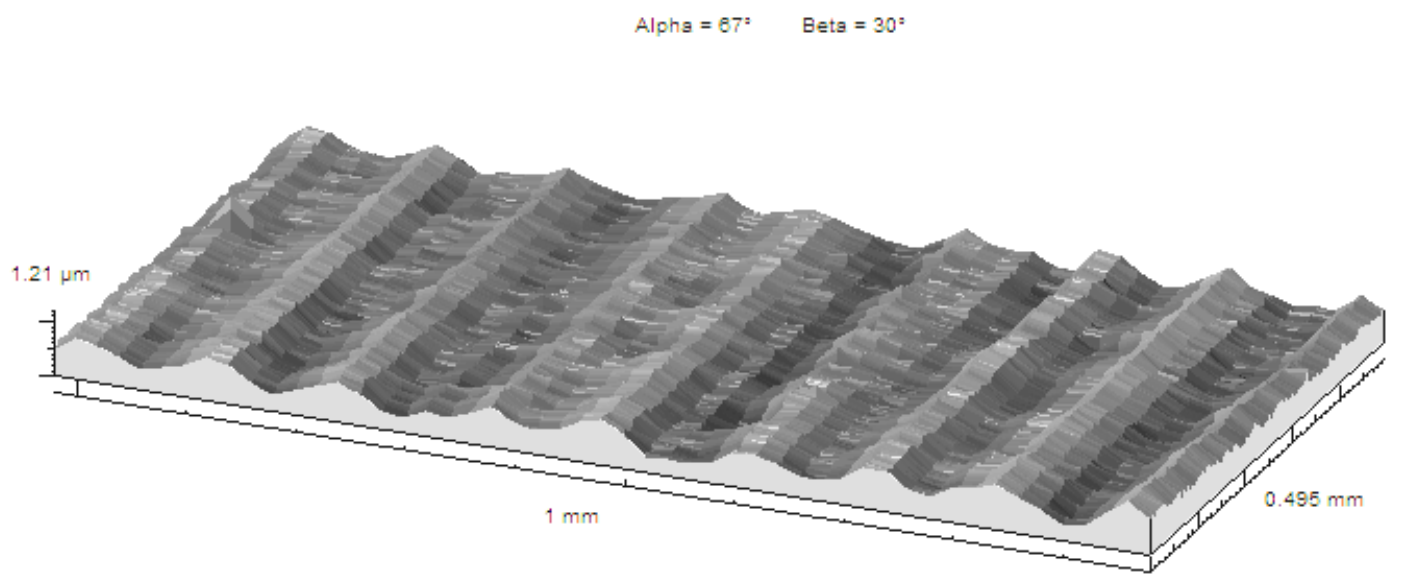

Figura 118. Topografia da superfície usinada com Velocidade de Corte $180 \mathrm{~m} / \mathrm{min}$ e Avanço 0,12 $\mathrm{mm} / \mathrm{rot}$.

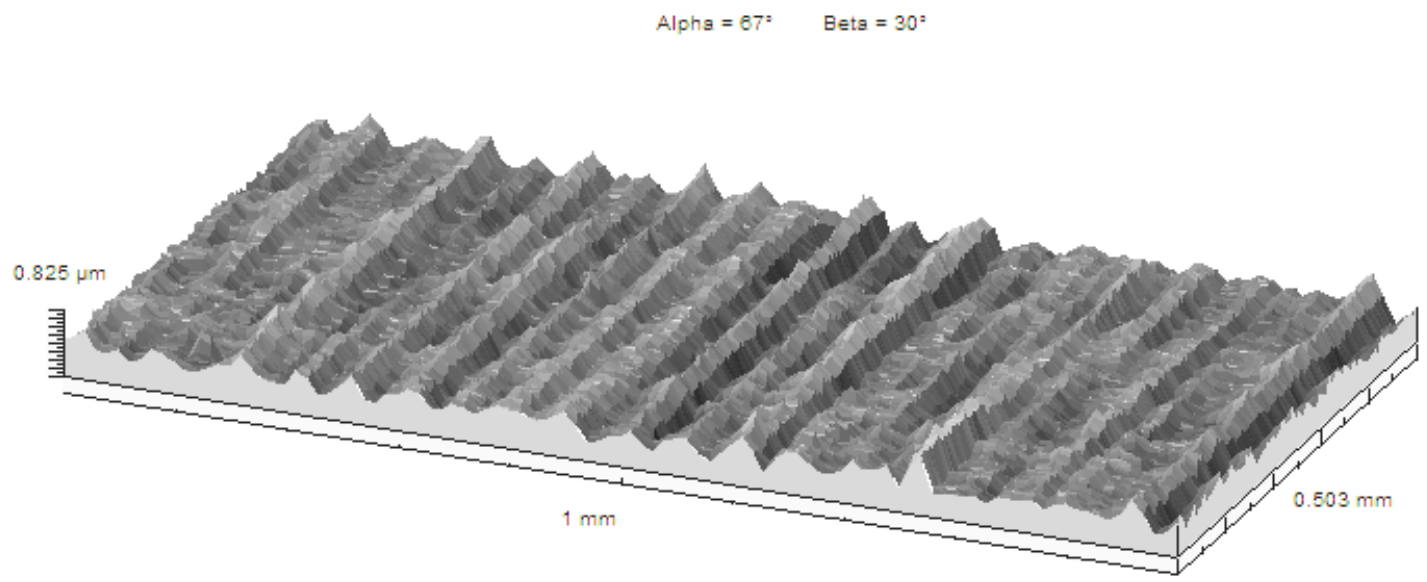

Figura 119. Topografia da superfície usinada com Velocidade de Corte $200 \mathrm{~m} / \mathrm{min}$ e Avanço 0,05 $\mathrm{mm} / \mathrm{rot}$.

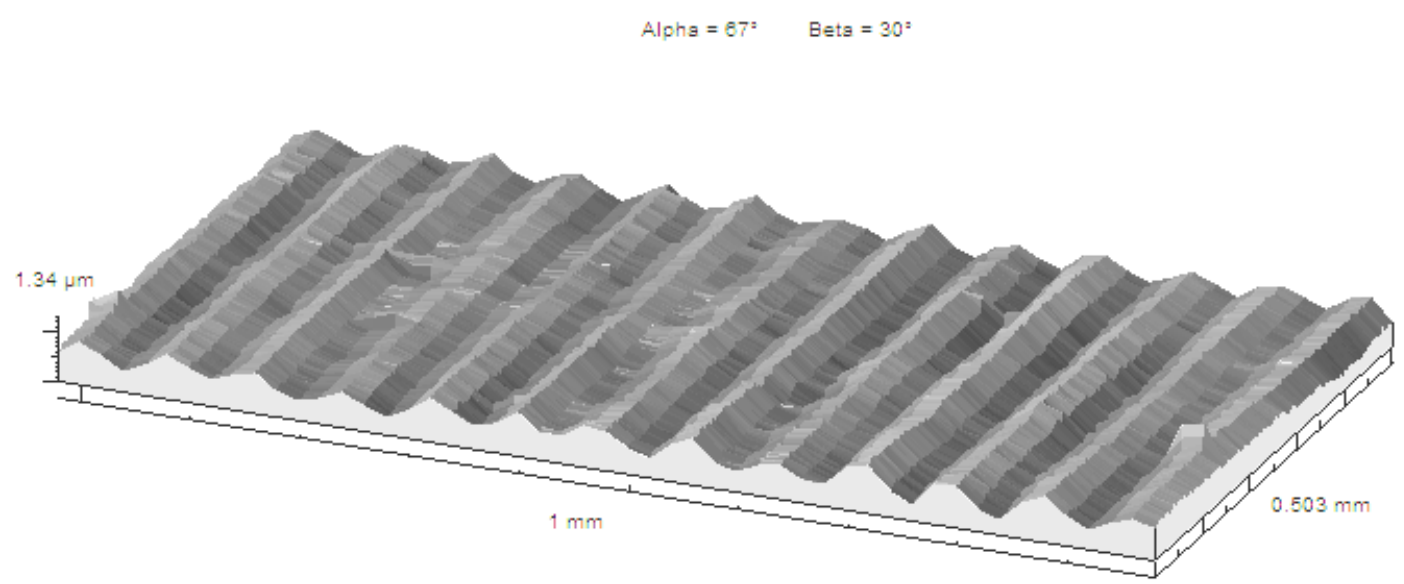

Figura 120. Topografia da superfície usinada com Velocidade de Corte $200 \mathrm{~m} / \mathrm{min}$ e Avanço 0,08 $\mathrm{mm} / \mathrm{rot}$. 


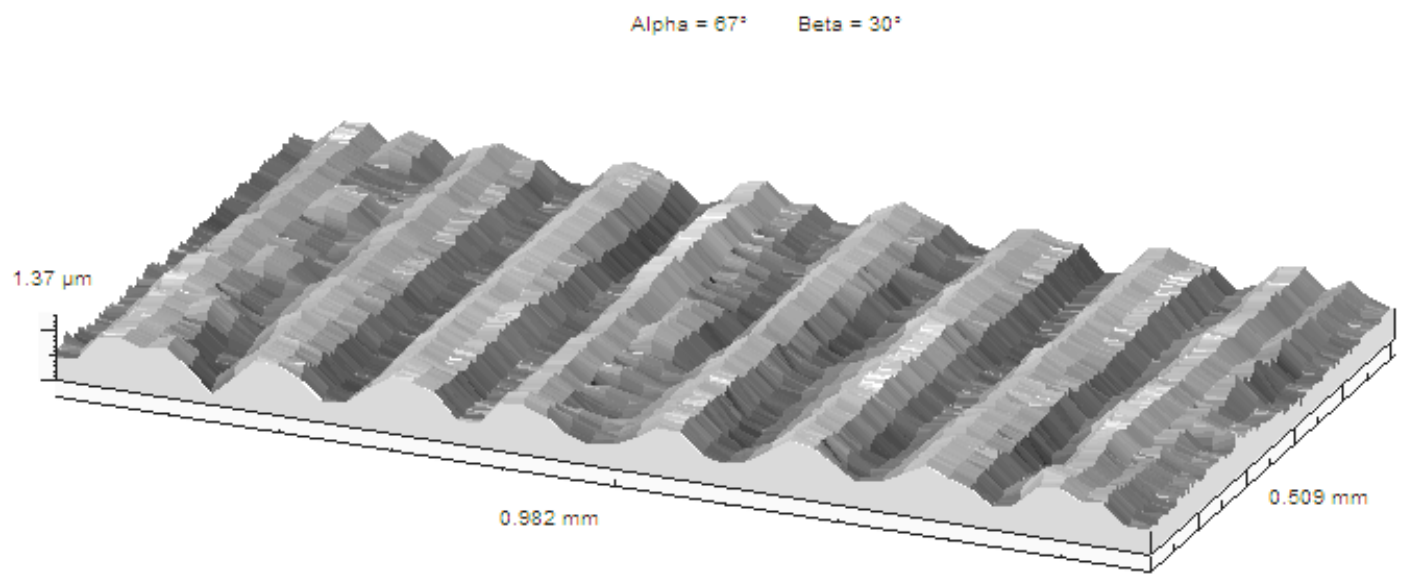

Figura 121. Topografia da superfície usinada com Velocidade de Corte $200 \mathrm{~m} / \mathrm{min}$ e Avanço 0,12 $\mathrm{mm} / \mathrm{rot}$.

A Figura 122 apresenta a topografia 3-D do corpo de prova retificado em uma retificadora cilíndrica com condições convencionais, é notada uma maior isotropia da superfície, pois a ferramenta rebolo utilizada consiste de inúmeras arestas de corte (grãos do rebolo) que provocam o arranque de material ao mesmo tempo. Ainda é verificado um alinhamento (anisotropia) devido à característica do giro do corpo de prova no sentido radial durante o contato com o rebolo, característico do processo de retificação cilíndrica.

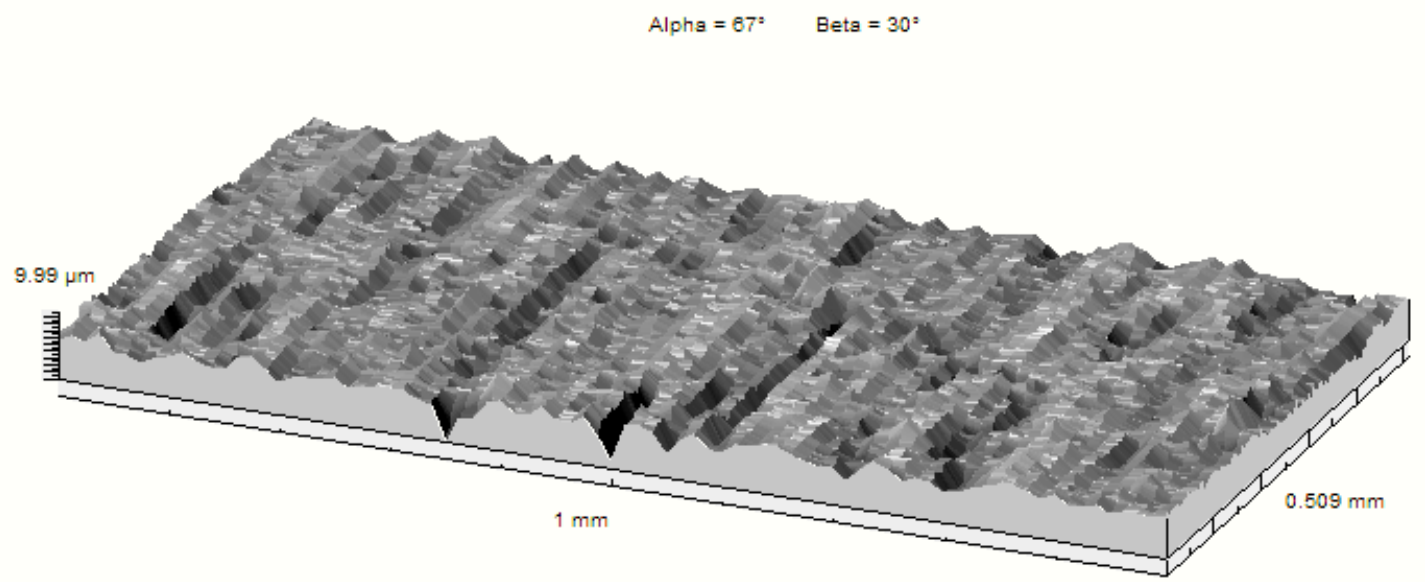

Figura 122. Topografia da superfície Retificada em condições convencionais.

Em comparação com a superfície retificada, as superfícies geradas pelo torneamento apresentam uma maior regularidade e previsibilidade, ou seja, pode-se esperar aproximadamente a mesma superfície em todas as regiões da peça. $O$ contrário se nota na retificação que apresenta uma topografia mais irregular demonstrando menor previsibilidade. 


\subsection{Análise dos Parâmetros de Amplitude de Rugosidade}

A Figura 123 e Figura 124 apresentam valores das rugosidades: média aritmética $S_{a}$ e média quadrática $S_{q}$. Ambas obtidas em função do par velocidade de corte e avanço utilizados no experimento, as barras indicam o desvio padrão.

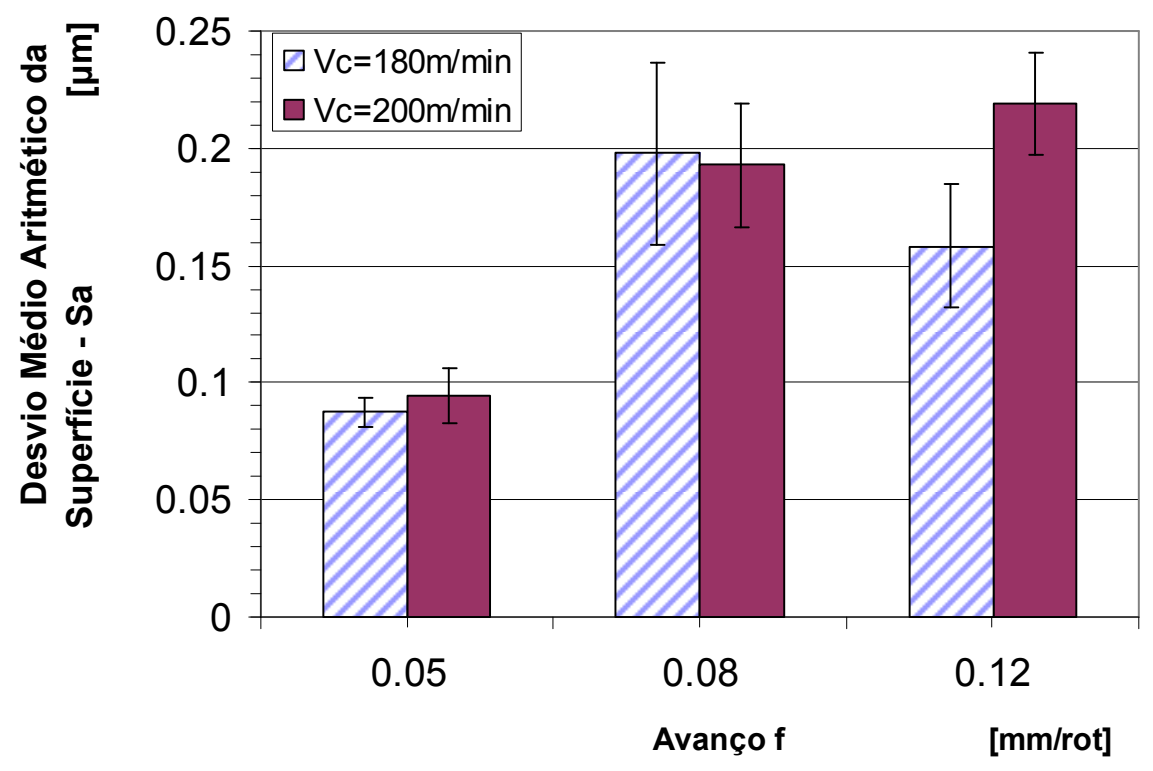

Figura 123. Desvio Médio Aritmético da Superfície - $S_{a}$

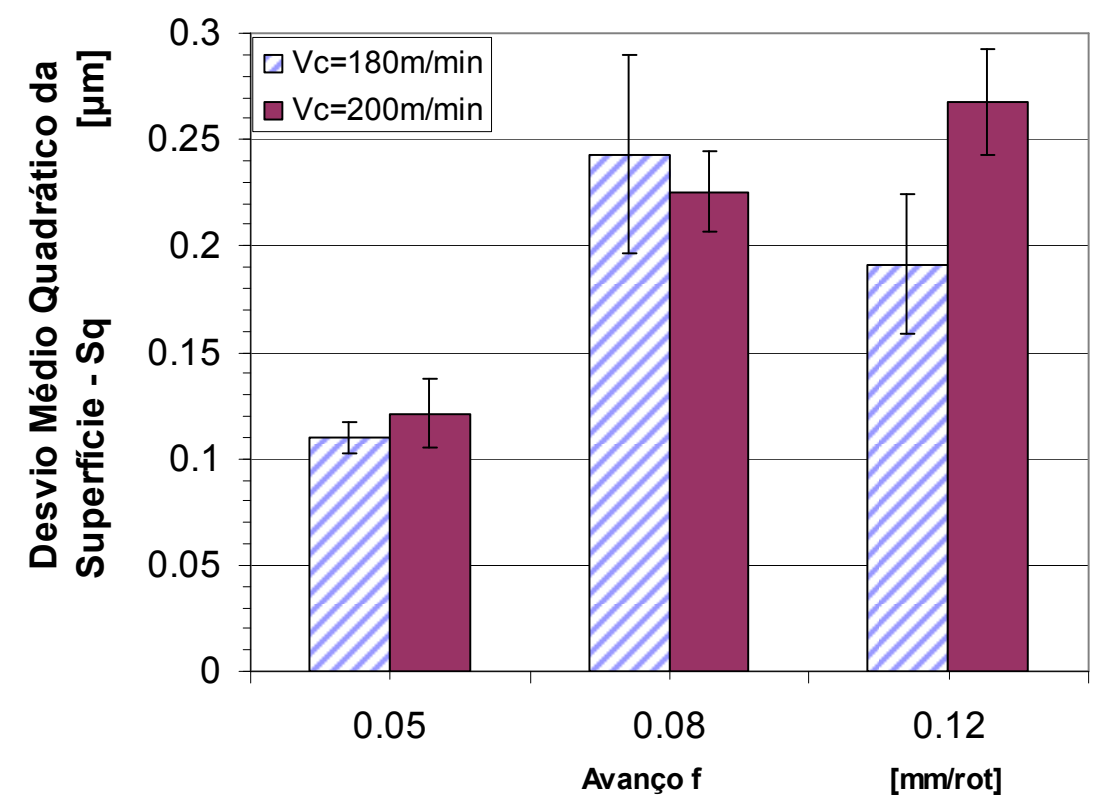

Figura 124. Desvio Médio Quadrático da Superfície - $S_{q}$

Observando as Figuras 123 e 124, verifica-se baixos valores de rugosidades médias atribuído para o torneamento com pastilhas multiraio (wiper). 


\subsection{Análise dos Parâmetros Funcionais de Forma}

As Figuras 125 e 126 apresentam os valores das rugosidades assimetria da distribuição das alturas $S_{s k}$ e Curtose da Distribuição das Alturas $S_{k u}$, obtidas em função do par velocidade de corte e avanço utilizados no experimento, junto aos valores estão indicados pelas barras o desvio padrão.

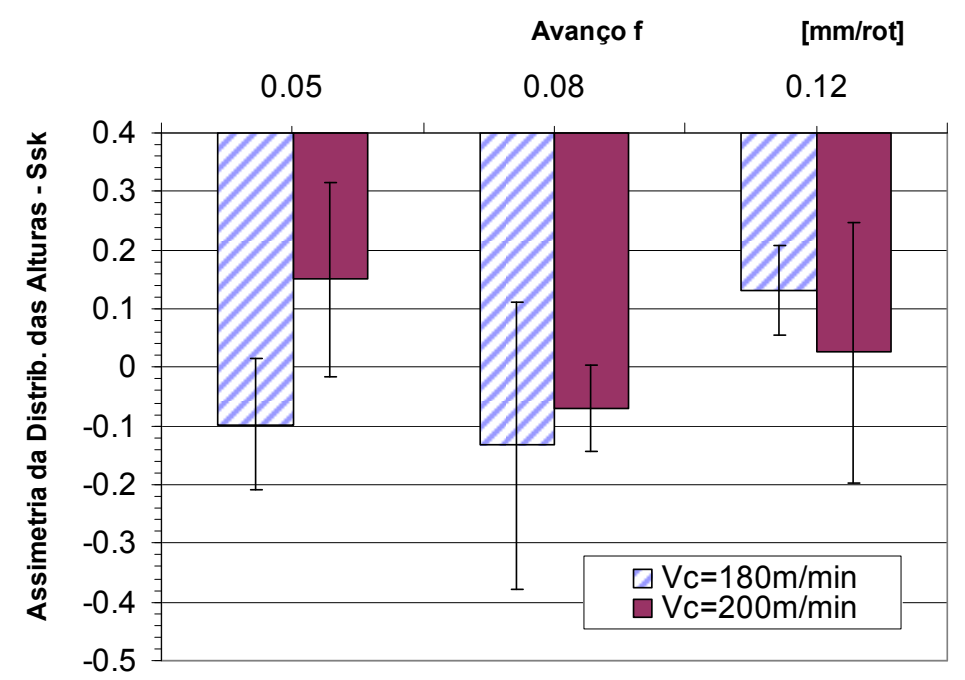

Figura 125. Assimetria da Distribuição das Alturas $S_{s k}$

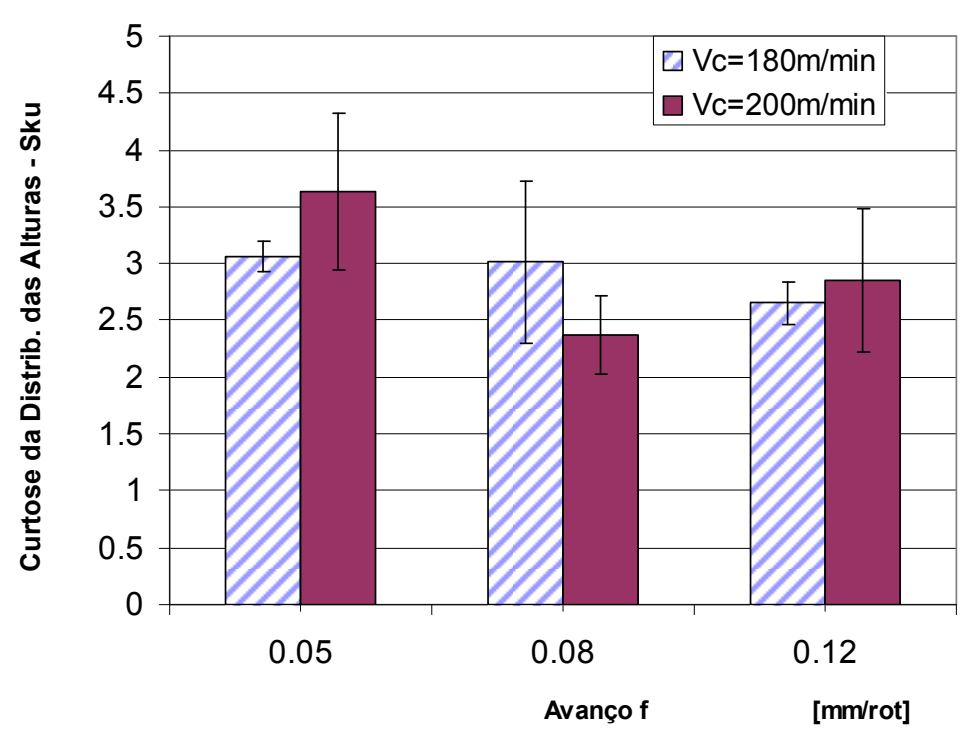

Figura 126. Curtose da Distribuição das Alturas $S_{k u}$

Analisando as Figuras 125 e 126, verificamos que a superfície apresenta simetria de distribuição entre picos e vales $\left(S_{\mathrm{ku}} \sim=3\right)$, possui distribuição de picos aleatória $\left(S_{s_{k}} \sim=0\right)$, apresenta boa capacidade de carregamento e resistência ao desgaste prematuro e razoável capacidade de retenção de fluidos. 


\subsection{Análise dos Parâmetros Funcionais da Distribuição das Alturas Baseados na Curva da Área de Carregamento}

As Figuras 127 a 131 apresentam os valores para as rugosidades $S_{p k}$ (Altura Reduzida do Pico), $S_{k}$ (Profundidade da Rugosidade do Núcleo), $S_{v k}$ (Profundidade reduzida do Vale) e as porção de material da superfície $\mathrm{M}_{\mathrm{r} 1}$ e $\mathrm{M}_{\mathrm{r} 2}$, obtidas em função do par Velocidade de corte e avanço utilizados no experimento, junto aos valores estão indicados pelas barras o desvio padrão.

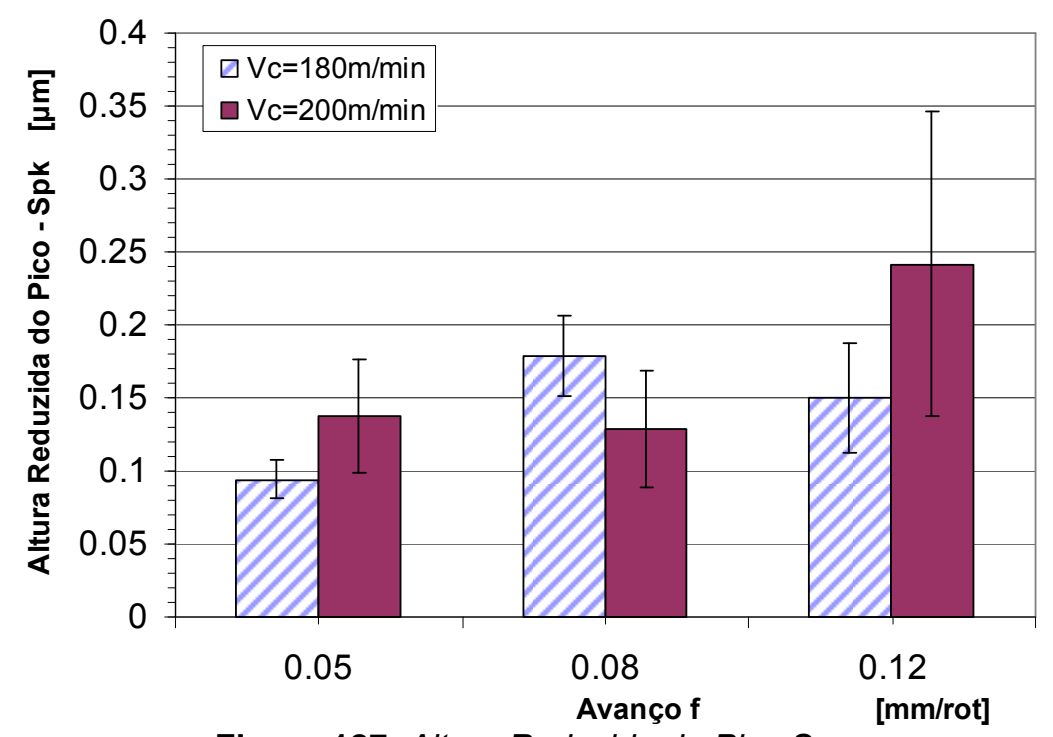

Figura 127. Altura Reduzida do Pico $S_{p k}$

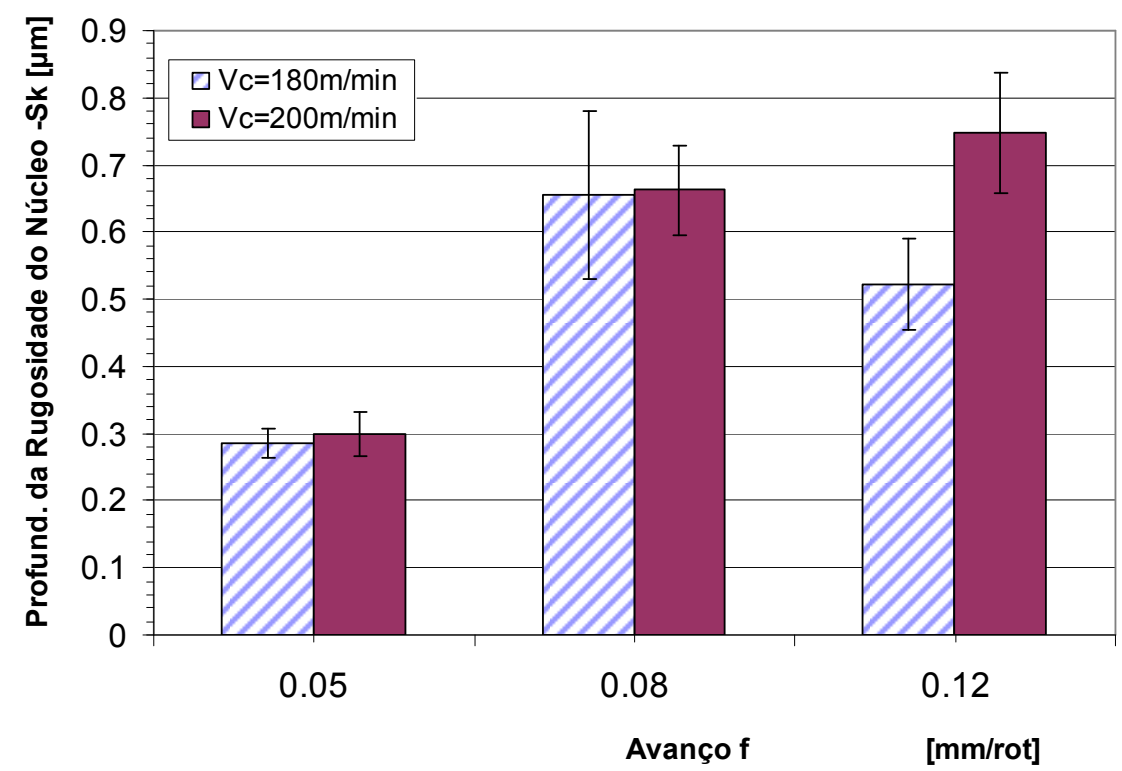

Figura 128. Profundidade da Rugosidade do Núcleo $S_{k}$ 


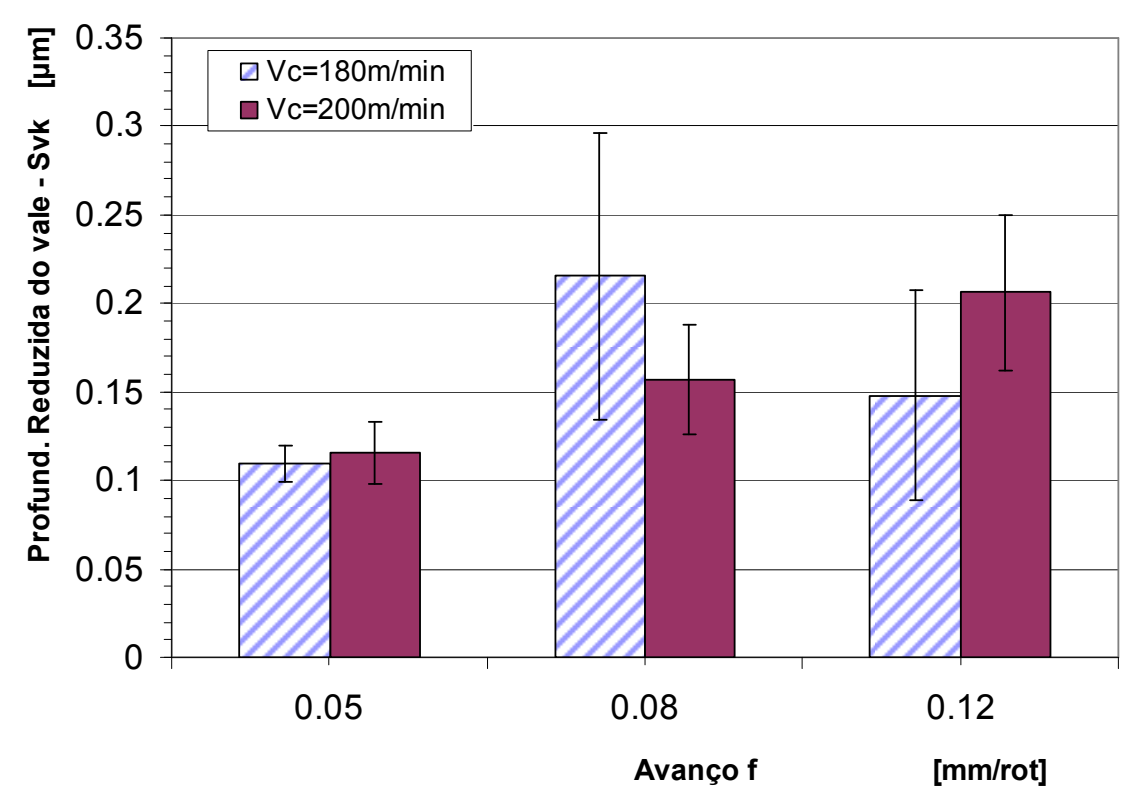

Figura 129. Profundidade reduzida do Vale $S_{v k}$

Analisando a superfície com os parâmetros da curva de área de carregamento pode-se verificar razoável resistência ao desgaste prematuro, razoável capacidade de carregamento e baixa capacidade de retenção de fluídos devido aos baixos valores encontrados na rugosidade $S_{\mathrm{vk}}$. É possível verificar que a variação dos dados de corte pode influenciar a condição funcional resultante, pois observa-se nas Figuras 127, 128 e 129 uma alteração nos resultados em função do avanço utilizado na usinagem.

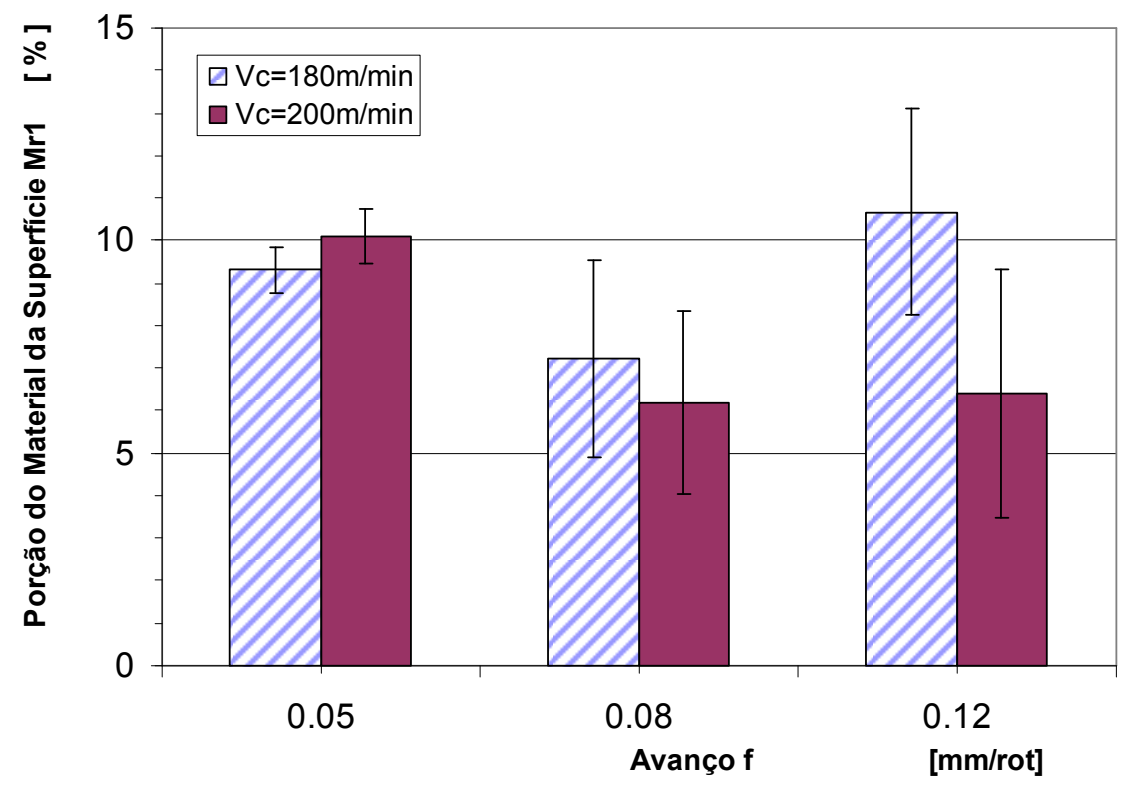

Figura 130. Porção do Material da Superfície $M_{r 1}$ 


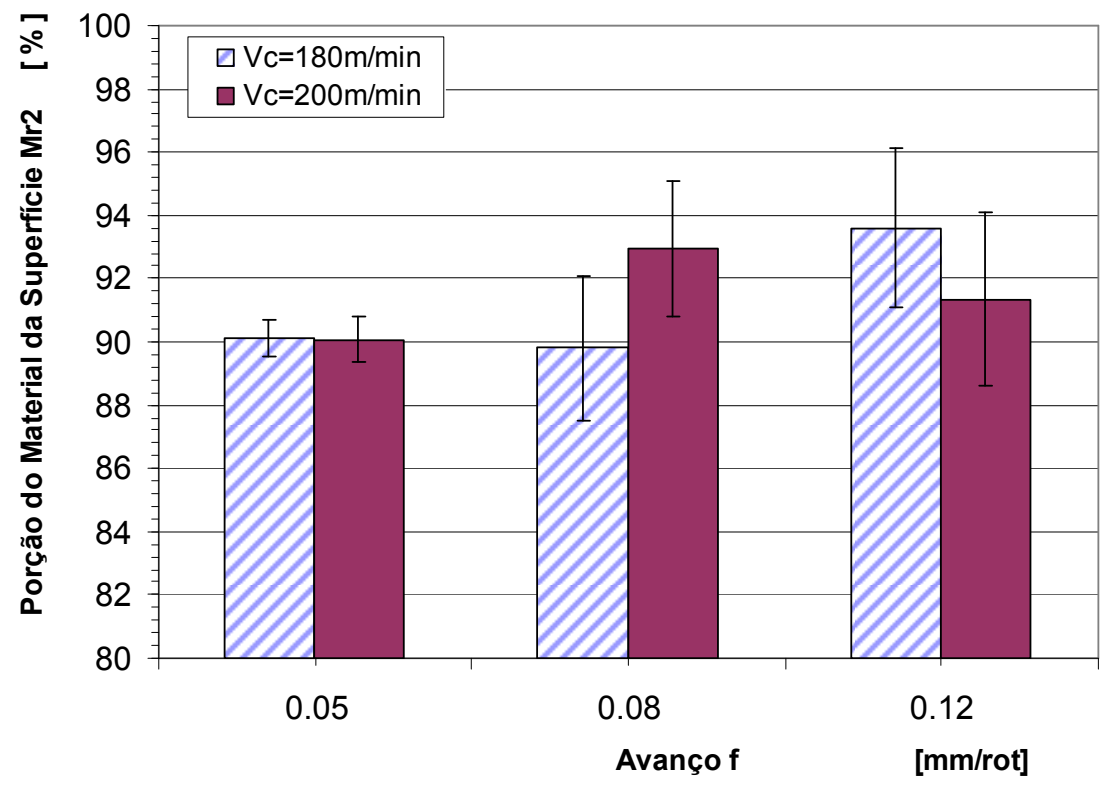

Figura 131. Porção do Material da Superfície $M_{r 2}$

A maior parte da superfície encontra-se na região central da curva de área de carregamento, indicando que a capacidade de carregamento é predominante.

\subsection{Camada de Material Afetada}

\subsubsection{Camada Branca}

Para análise da CB e CMA foram executadas metalografias ópticas para visualização de possíveis mudanças na estrutura interna da camada cementada. As Figuras 132 a 137 apresentam as metalografias ópticas das amostras analisadas.

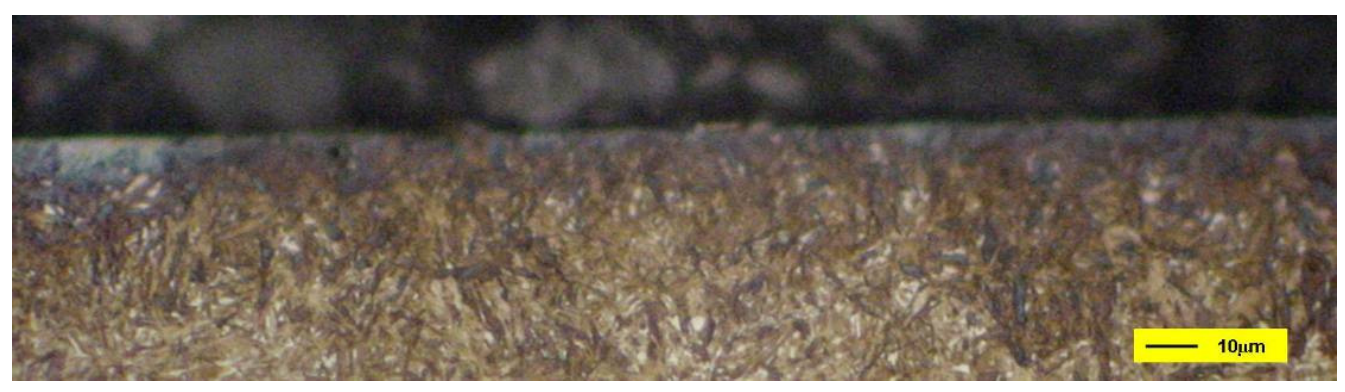

Figura 132. Amostra com $V_{\mathrm{c}}=180 \mathrm{~m} / \mathrm{min}$ e $f=0.05 \mathrm{~mm} / \mathrm{rot}$. 


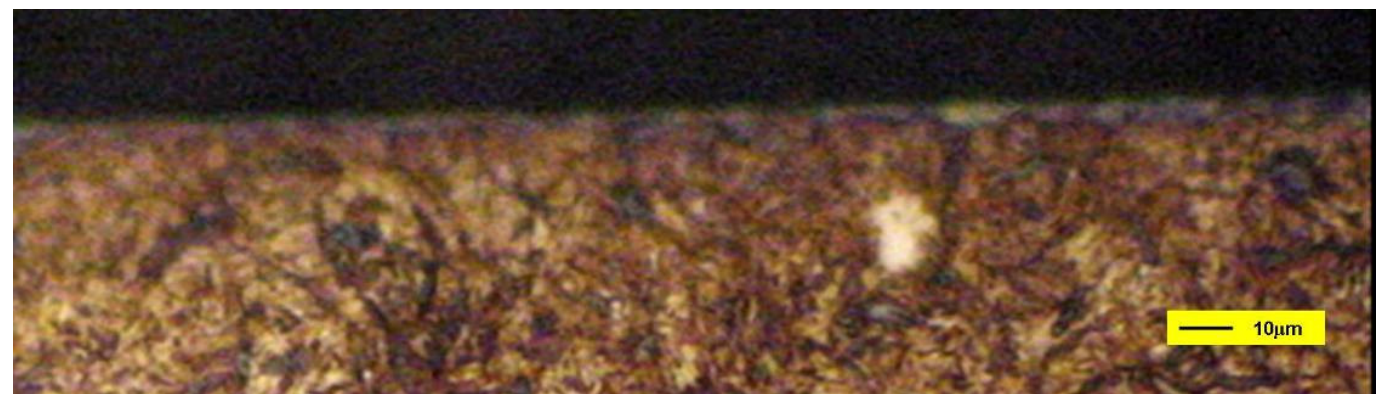

Figura 133. Amostra com $V_{c}=180 \mathrm{~m} / \mathrm{min}$ e $f=0.08 \mathrm{~mm} / \mathrm{rot}$.

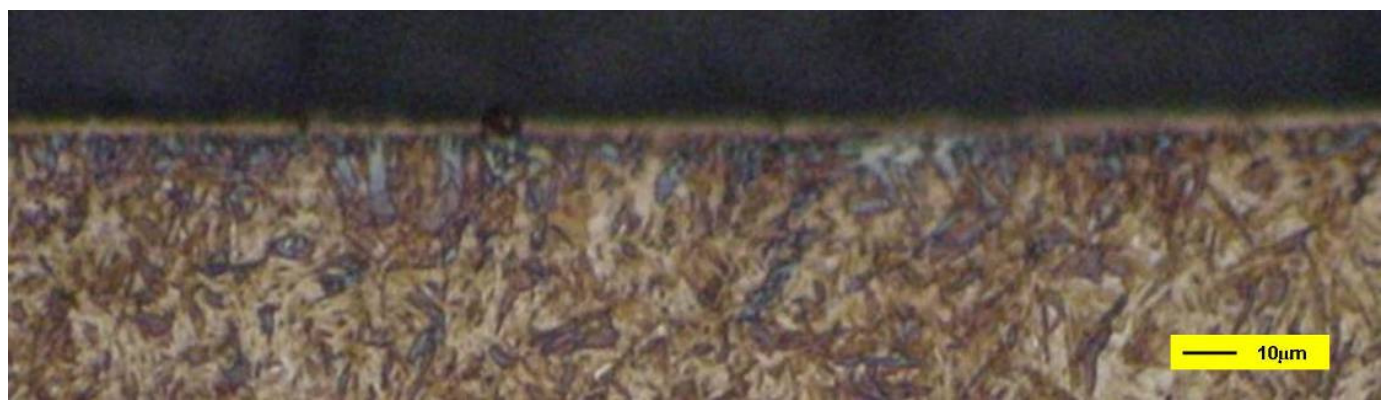

Figura 134. Amostra com $V_{c}=180 \mathrm{~m} / \mathrm{min}$ e $f=0.12 \mathrm{~mm} / \mathrm{rot}$.

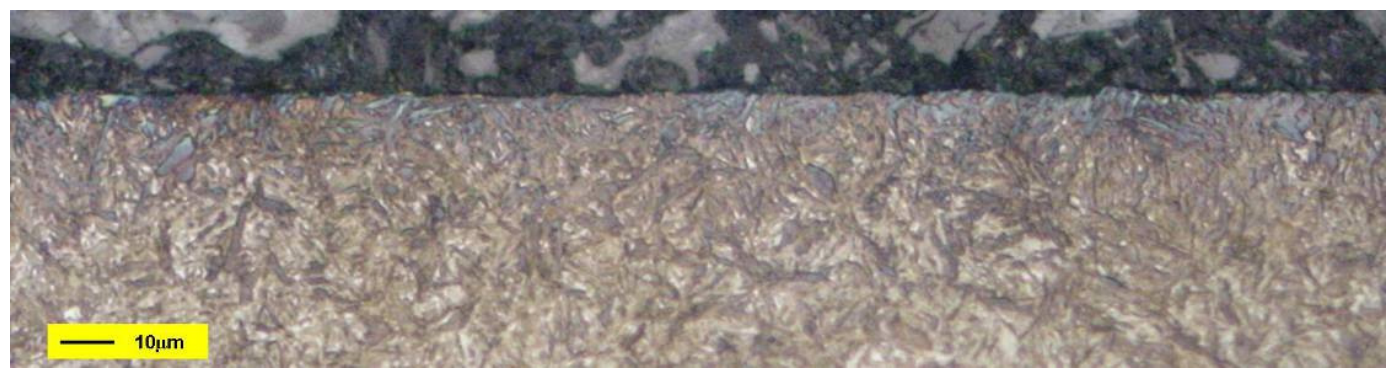

Figura 135. Amostra com $V_{c}=200 \mathrm{~m} / \mathrm{min}$ e $f=0.05 \mathrm{~mm} / \mathrm{rot}$.

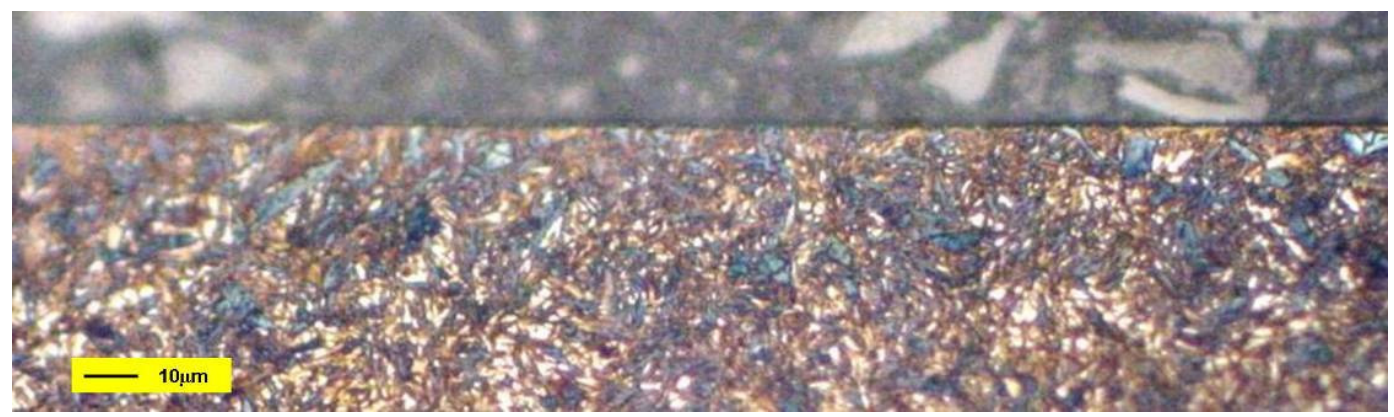

Figura 136. Amostra com $V_{c}=200 \mathrm{~m} / \mathrm{min}$ e $\mathrm{f}=0.08 \mathrm{~mm} / \mathrm{rot}$.

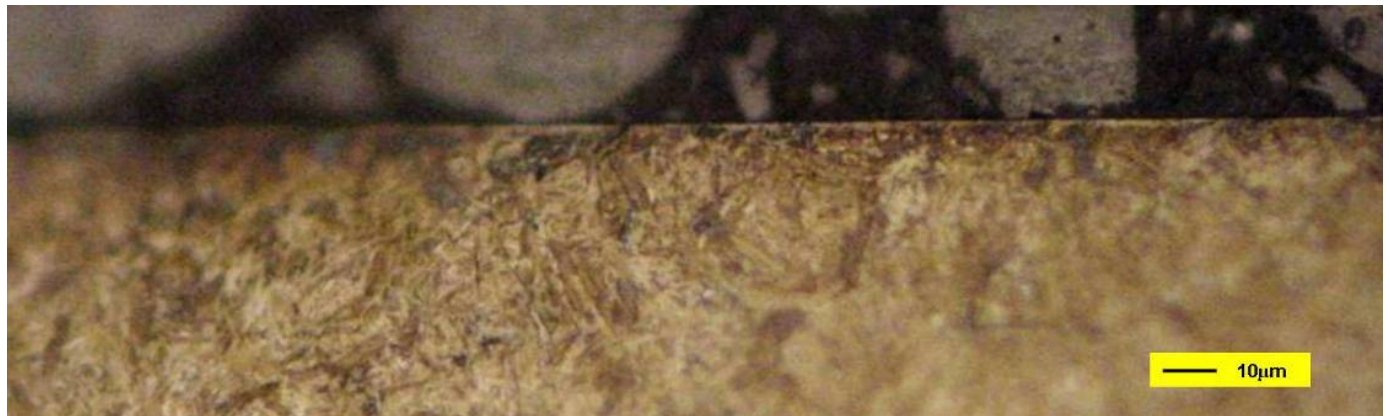

Figura 137. Amostra com $V_{c}=200 \mathrm{~m} / \mathrm{min}$ e $f=0.12 \mathrm{~mm} / \mathrm{rot}$. 
Adicionalmente duas amostras na maior condição de velocidade de corte $\left(\mathrm{V}_{\mathrm{c}}=\right.$ $200 \mathrm{~m} / \mathrm{min}$ ) foram analisadas com o auxilio do microscópio eletrônico de varredura (MEV), visando uma melhor visualização das possíveis camadas afetadas pela usinagem, Figura 138 e Figura 139.

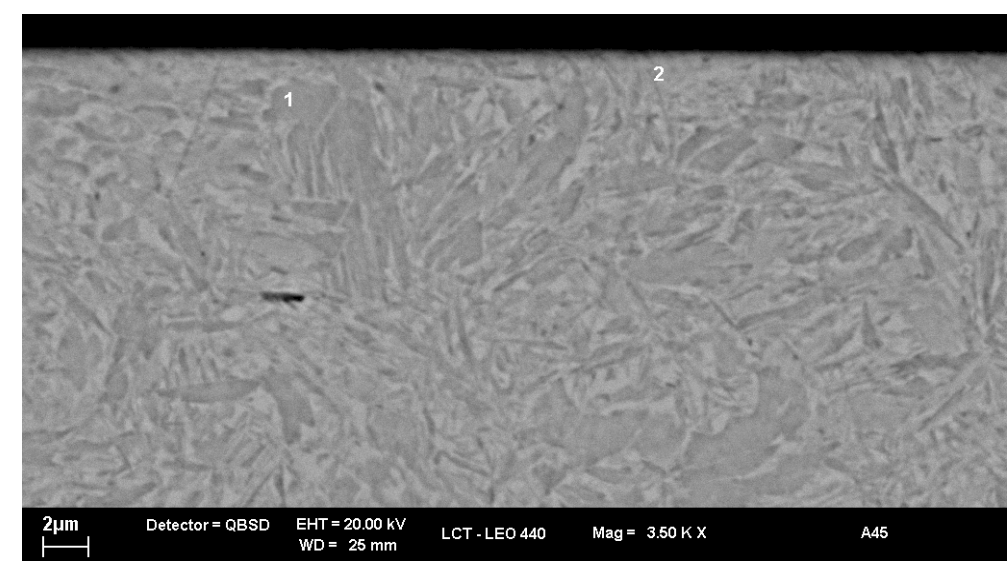

Figura 138. Amostra MEV com $V_{\mathrm{c}}=200 \mathrm{~m} / \mathrm{min}$ e $\mathrm{f}=0.05 \mathrm{~mm} / \mathrm{rot}$.

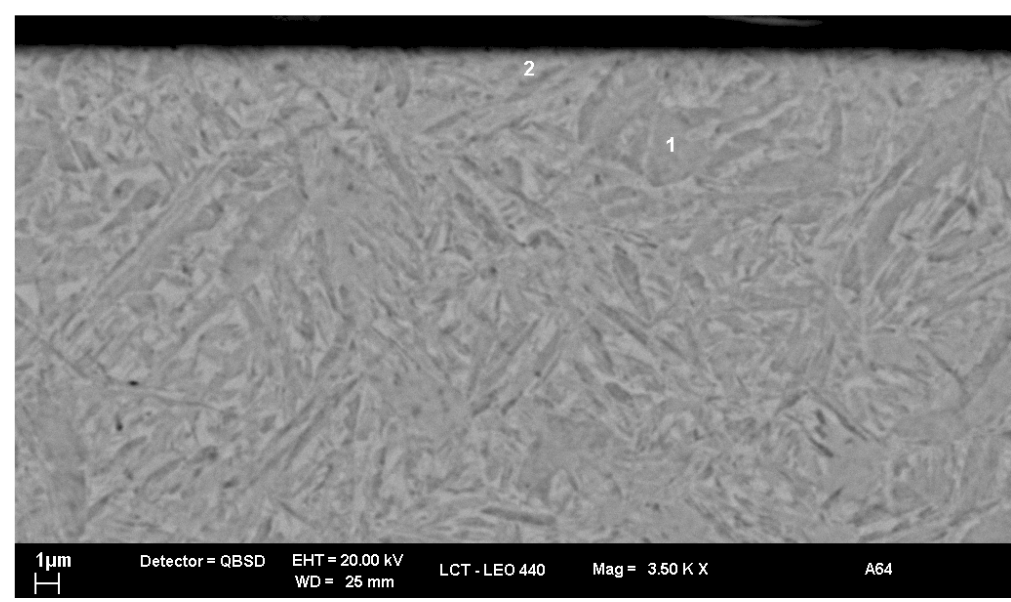

Figura 139. Amostra MEV com $V_{c}=200 \mathrm{~m} / \mathrm{min}$ e $f=0.12 \mathrm{~mm} / \mathrm{rot}$.

\subsubsection{Perfil de Dureza da Camada Cementada após Usinagem}

A Figura 140 apresenta micrografias MEV das endentações executadas para medição da dureza da camada. A Figura 141 apresenta o resultado das curvas de durezas da camada cementada após o torneamento endurecido. A linha que cruza o valor de $550 \mathrm{HV}$ indica, de acordo com a norma DIN 50 190, o fim da camada cementada. De acordo com a Figura 141 não foram detectadas modificações expressivas na dureza da camada principalmente na região limítrofe da área transversal com a superfície. 
(a)

(b)

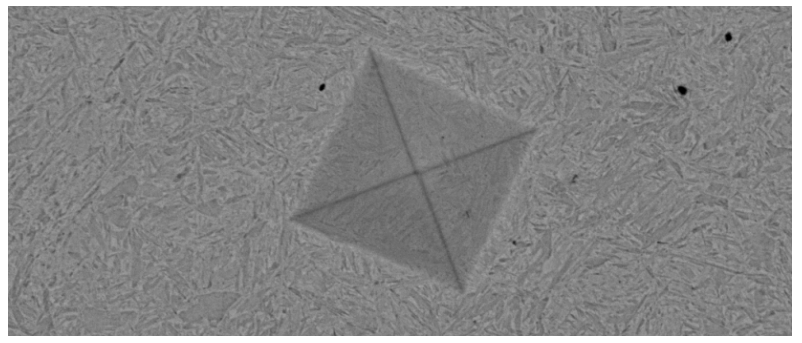

(c)
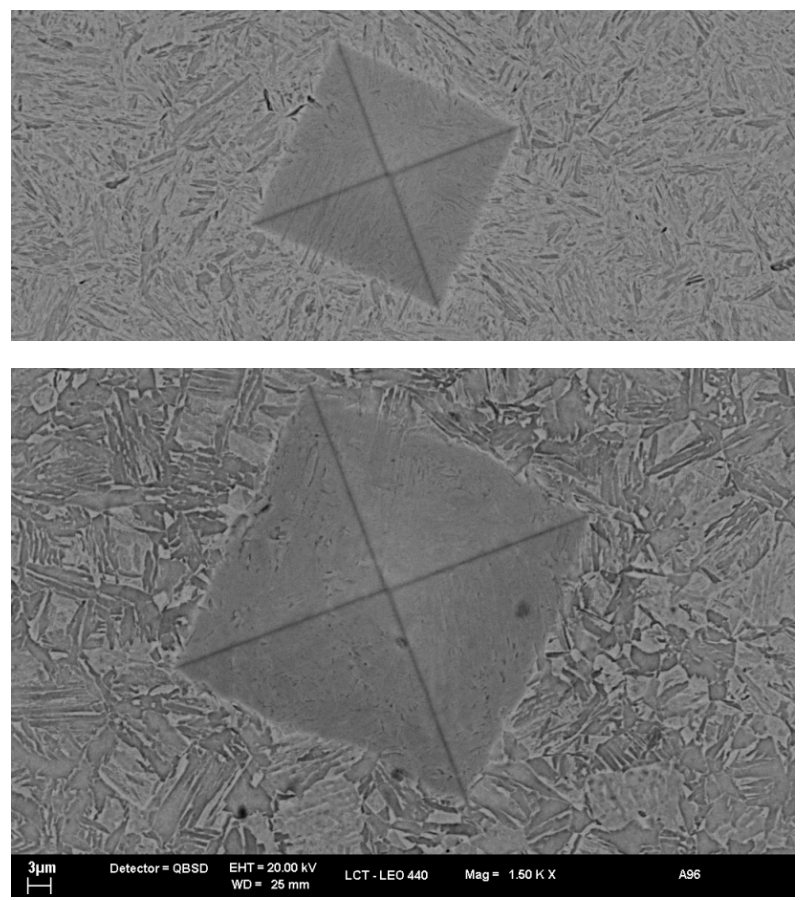

Figura 140. Endentações para medição em Vickers (a) Inicio da camada, (b) meio da camada e (c) fim da camada.

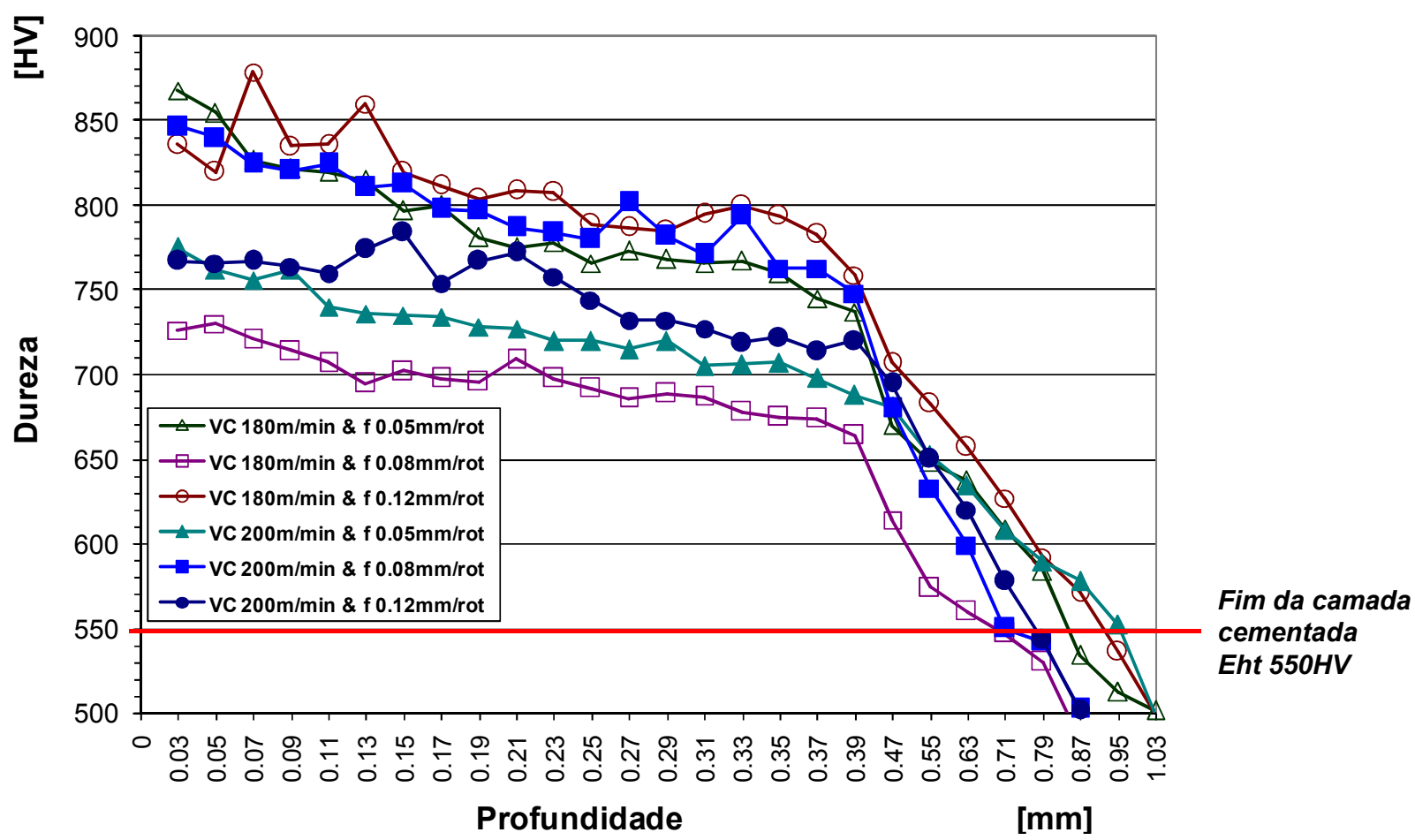

Figura 141. Curva de dureza da camada cementada após o torneamento endurecido, carga de $0,49 \mathrm{~N}(0,05 \mathrm{~kg})$. 


\section{DISCUSSÕES DOS RESULTADOS}

\subsection{Tensão Residual}

A medição de tensão residual, pelo método do furo cego, possibilitou o levantamento de um perfil de tensões induzidas no sentido axial e circunferencial das peças, indicando que o ponto de máximo valor compressivo foi atingido na profundidade média de $70 \mu \mathrm{m}(\sigma=5 \mu \mathrm{m})$ para o sentido axial e circunferencial.

De acordo com a análise efetuada em uma peça no estado anterior à usinagem (cementado), as tensões próximas à região superficial encontravam-se na faixa da tensão de tração até uma profundidade entre 40 e $50 \mu \mathrm{m}$. O torneamento em material endurecido induziu tensão de compressão nesta região, observou-se uma grande variação nos perfis de tensão, porém, o perfil de todas as amostras usinadas se encontrou na faixa de tensão de compressão.

Comparativamente ao perfil de tensão da condição retificada, o torneamento em material endurecido tem a capacidade de induzir maiores intensidades de tensão de compressão, pois como pôde ser observado o valor máximo de tensão (compressiva) atingido com o processo de retificação situou-se na faixa de $-111 \mathrm{MPa}$ enquanto que no torneado o valor máximo chegou a aproximadamente $-595 \mathrm{MPa}$.

A tensão residual na superfície, obtida com o método da difração de raios- $X$, apresentou-se compressiva em todos os casos analisados. Foram encontrados valores médios de $-150 \mathrm{MPa}$ a $-520 \mathrm{MPa}$. A medição da tensão com raios-X apresentou grande dispersão nos resultados de algumas amostras, a mais significativa foi na amostra com parâmetros de usinagem: velocidade de corte $V_{c}=200 \mathrm{~m} / \mathrm{min}$ e avanço $f=0,12 \mathrm{~mm} /$ rot.

A análise de variância (ANOVA) da tensão residual nas amostras indicou uma significante interação com a variável avanço (f), e também se mostra significativa a interação entre as duas variáveis conjuntas velocidade de corte $\left(V_{c}\right)$ e avanço (f). A Tabela 13 apresenta o resultado do teste de variância ANOVA com 95\% de nível de confiança. 
Tabela 13. Resultados ANOVA para Tensão Residual superficial.

\begin{tabular}{lccccc}
\multicolumn{1}{l}{} & \multicolumn{1}{c}{} & & $\begin{array}{c}\text { Referência } \\
\mathrm{P} \leq 0.05\end{array}$ \\
\hline Variável & $\mathrm{SS}$ & $\mathrm{df}$ & $\mathrm{MS}$ & $\mathrm{F}$ & valor-P \\
\hline $\mathrm{V}_{\mathrm{c}}$ & 1431 & 1 & 1431 & 0.08 & 0.7840 \\
\hline $\mathrm{f}$ & 280268 & 2 & 140134 & 7.49 & 0.0020 \\
\hline $\mathrm{V}_{\mathrm{c}}$ \& $\mathrm{f}$ & 395315 & 2 & 197657 & 10.56 & 0.0000 \\
\hline
\end{tabular}

A Figura 142 apresenta o gráfico tridimensional da tensão residual circunferencial, em função dos parâmetros velocidade de corte $\left(\mathrm{V}_{\mathrm{c}}-\mathrm{m} / \mathrm{min}\right)$ e avanço (f-mm/rot). Os círculos plotados indicam a média e o desvio padrão dos valores medidos. Nesta visualização é possível verificar a influência de cada um dos parâmetros de corte no resultado da tensão residual.

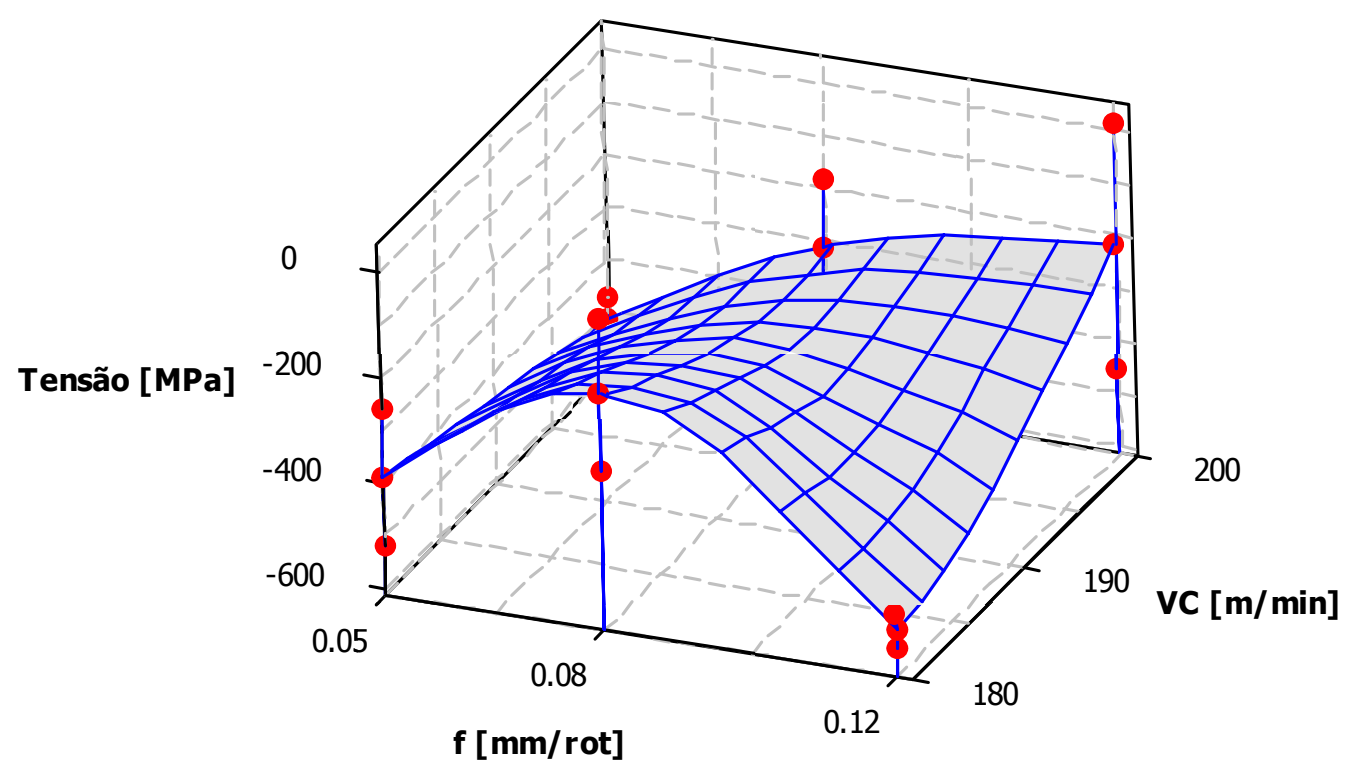

Figura 142. Gráfico tridimensional da Tensão Residual em função da Velocidade de Corte e Avanço.

\subsection{Rugosidade das Topografias}

A Tabela 14 apresenta os resultados da análise de variância (ANOVA) na medição topográfica superficial em função da variável Avanço (f em $\mathrm{mm} / \mathrm{rot}$ ), Velocidade de corte $\left(V_{c}\right.$ em $\left.\mathrm{m} / \mathrm{min}\right)$ e a interação dos dois parâmetros. 
Tabela 14. Resultados ANOVA para topografia superficial.

\begin{tabular}{|c|c|c|c|c|c|}
\hline & & & & & $\begin{array}{c}\text { Referência } \\
P \leq 0.05\end{array}$ \\
\hline \multicolumn{6}{|c|}{$\mathbf{S}_{\mathrm{a}}$ : Desvio Médio Aritmético da Superfície } \\
\hline Variável & SS & $\mathrm{df}$ & MS & $\mathrm{F}$ & valor-P \\
\hline$f$ & 0.0817 & 2 & 0.0409 & 69.2815 & 0.0000 \\
\hline $\mathrm{V}_{\mathrm{c}}$ & 0.0040 & 1 & 0.0040 & 6.7062 & 0.0147 \\
\hline$f \& V_{c}$ & 0.0074 & 2 & 0.0037 & 6.2466 & 0.0054 \\
\hline \multicolumn{6}{|c|}{$\mathbf{S}_{\mathrm{q}}$ : Desvio Médio Quadrático da Superfície } \\
\hline Variável & SS & $\mathrm{df}$ & MS & $\mathrm{F}$ & valor-P \\
\hline$f$ & 0.1088 & 2 & 0.0544 & 71.6062 & 0.0000 \\
\hline$\overline{V_{c}}$ & 0.0048 & 1 & 0.0048 & 6.3665 & 0.0172 \\
\hline$f \& V_{c}$ & 0.0138 & 2 & 0.0069 & 9.1087 & 0.0008 \\
\hline \multicolumn{6}{|c|}{$\mathbf{S}_{\mathbf{k u}}:$ Curtose da Distribuição das Alturas da Topografia } \\
\hline Variável & SS & $\mathrm{df}$ & MS & $\mathrm{F}$ & valor-P \\
\hline$f$ & 3.1252 & 2 & 1.5626 & 6.0076 & 0.0064 \\
\hline$\overline{V_{c}}$ & 0.0196 & 1 & 0.0196 & 0.0754 & 0.7856 \\
\hline$f \& V_{c}$ & 2.3346 & 2 & 1.1673 & 4.4878 & 0.0197 \\
\hline \multicolumn{6}{|c|}{$\mathbf{S}_{\mathbf{s k}}$ : Assimetria da Distribuição das Alturas da Topografia } \\
\hline Variável & SS & $\mathrm{df}$ & MS & $\mathrm{F}$ & valor-P \\
\hline$f$ & 0.2064 & 2 & 0.1032 & 3.8590 & 0.0323 \\
\hline $\mathrm{V}_{\mathrm{c}}$ & 0.0426 & 1 & 0.0426 & 1.5915 & 0.2168 \\
\hline$f \& V_{c}$ & 0.1872 & 2 & 0.0936 & 3.5002 & 0.0430 \\
\hline \multicolumn{6}{|c|}{$\mathbf{S}_{\mathbf{p k}}:$ Altura Reduzida do Pico } \\
\hline Variável & SS & $\mathrm{df}$ & MS & $\mathrm{F}$ & valor-P \\
\hline$f$ & 0.0386 & 2 & 0.0193 & 7.0719 & 0.0030 \\
\hline$\overline{V_{c}}$ & 0.0071 & 1 & 0.0071 & 2.6071 & 0.1169 \\
\hline$f \& V_{c}$ & 0.0311 & 2 & 0.0155 & 5.6979 & 0.0080 \\
\hline \multicolumn{6}{|c|}{$\mathbf{S}_{\mathrm{vk}}:$ Profundidade reduzida do Vale } \\
\hline Variável & SS & $\mathrm{df}$ & MS & $\mathrm{F}$ & valor-P \\
\hline$f$ & 0.0388 & 2 & 0.0194 & 8.7375 & 0.0010 \\
\hline $\mathrm{V}_{\mathrm{c}}$ & 0.0000 & 1 & 0.0000 & 0.0145 & 0.9048 \\
\hline$f \& V_{c}$ & 0.0204 & 2 & 0.0102 & 4.6010 & 0.0181 \\
\hline \multicolumn{6}{|c|}{$\mathbf{S}_{\mathbf{k}}:$ Profundidade da Rugosidade do Núcleo } \\
\hline Variável & SS & $\mathrm{df}$ & $\mathrm{MS}$ & $\mathrm{F}$ & valor-P \\
\hline$f$ & 1.0063 & 2 & 0.5032 & 88.4461 & 0.0000 \\
\hline $\mathrm{V}_{\mathrm{c}}$ & 0.0605 & 1 & 0.0605 & 10.6373 & 0.0028 \\
\hline$f \& V_{c}$ & 0.0925 & 2 & 0.0462 & 8.1295 & 0.0015 \\
\hline
\end{tabular}


Para a análise da influência dos parâmetros (hipótese alternativa), utilizou-se o processo do valor da probabilidade (valor-P) do teste, que diz:

a) Se o valor-P é menor ou igual a um determinado nível de significância (nível $\alpha)$, a hipótese de nulidade é rejeitada e a hipótese alternativa é apoiada.

b) Se o valor-P é maior que o nível $\alpha$, a hipótese de nulidade não pode ser rejeitada e a hipótese alternativa não tem apoio.

O teste de variância (ANOVA), com 95\% de nível de confiança, indicou que o avanço $f$ é a variável mais significativa entre as interações com os parâmetros: Rugosidade Média - $S_{a}$, Rugosidade Média Quadrática - $S_{q}$, Altura Reduzida de Pico - $S_{\mathrm{pk}}$, Profundidade Reduzida de Vale $S_{\mathrm{vk}}$, Profundidade da Rugosidade do Núcleo $S_{k}$, Curtose - $S_{k u}$ e Assimetria - $S_{\text {sk }}$. Em segundo lugar a interação entre as duas variáveis $V_{c}$ e $f$ também mostraram significância com todos os parâmetros de rugosidades. A velocidade de corte $V_{c}$ se apresenta significativa nos parâmetros $S_{a}$, $\mathrm{S}_{\mathrm{q}}$ e $\mathrm{S}_{\mathrm{k}}$, não mostrando significância para os demais.

Os resultados obtidos na medição das rugosidades superficiais apresentam coerência com resultados de outros autores (Grzesik et al, 2007 e Waikar e Guo, 2008), isto afirma a técnica de torneamento em material endurecido capaz de produzir superfícies com funcionalidade e qualidade. As Tabelas 15 e 16, apresentam comparações entre os resultados de outros autores que também estudaram a integridade superficial, no processo de torneamento em material endurecido utilizando parâmetros funcionais. São apresentados também os valores de referência para cada parâmetro apresentado. Como o avanço é a variável mais significativa, nas Tabelas 15 e 16 utilizou-se a média entre os valores encontrados para as duas condições de velocidade de corte.

Tabela 15. Resultados obtidos para torneamento duro e retificação (adaptado de Waikar e Guo, 2008).

\begin{tabular}{|c|c|c|c|c|c|c|c|}
\hline \multirow[b]{2}{*}{ Parâmetros } & \multicolumn{2}{|c|}{ Waikar e Guo (2008) } & \multirow{2}{*}{$\begin{array}{c}\text { Amostra } \\
\text { Retificada } \\
\text { Convencional }\end{array}$} & \multicolumn{3}{|c|}{ Experimento Torneamento Duro } & \multirow{2}{*}{$\begin{array}{l}\text { Referência para } \\
\text { melhor condição } \\
\text { funcional }\end{array}$} \\
\hline & Torneamento & Retificação & & $\begin{array}{l}f=0.05 \\
\mathrm{~mm} / \mathrm{rot}\end{array}$ & $\begin{array}{l}\mathrm{f}=0.08 \\
\mathrm{~mm} / \mathrm{rot}\end{array}$ & $\begin{array}{l}\mathrm{f}=0.12 \\
\mathrm{~mm} / \mathrm{rot}\end{array}$ & \\
\hline $\mathrm{S}_{\mathrm{a}}(\mu \mathrm{m})$ & 0.229 & 0.158 & 0.64 & 0.09 & 0.19 & 0.19 & - \\
\hline $\mathrm{S}_{\mathrm{q}}(\mu \mathrm{m})$ & 0.28 & 0.196 & 0.84 & 0.12 & 0.23 & 0.23 & - \\
\hline $\mathrm{S}_{\mathrm{sk}}$ & 0.53 & -0.127 & -0.51 & 0 & -0.1 & 0.09 & Valor $<0$ \\
\hline $\mathrm{S}_{\mathrm{ku}}$ & 2.88 & 2.79 & 4.85 & 3.4 & 2.7 & 2.8 & Valor $<3$ \\
\hline
\end{tabular}


Tabela 16. Resultados obtidos para torneamento duro e torneamento duro seguido de superacabamento (Torn. + SA) (adaptado de Grzesik et al, 2007).

\begin{tabular}{|c|c|c|c|c|c|c|c|}
\hline & \multicolumn{2}{|c|}{ Grzesik et al (2007) } & \multirow{2}{*}{$\begin{array}{c}\text { Amostra } \\
\text { Retificada } \\
\text { Convencional }\end{array}$} & \multicolumn{3}{|c|}{ Experimento Torneamento Duro } & \multirow{2}{*}{$\begin{array}{l}\text { Referência para } \\
\text { melhor condição } \\
\text { funcional }\end{array}$} \\
\hline Parâmetros & Torneamento & Torn. + SA & & $\begin{array}{l}\mathrm{f}=0.05 \\
\mathrm{~mm} / \mathrm{rot}\end{array}$ & $\begin{array}{l}\mathrm{f}=0.08 \\
\mathrm{~mm} / \mathrm{rot}\end{array}$ & $\begin{array}{l}\mathrm{f}=0.12 \\
\mathrm{~mm} / \mathrm{rot}\end{array}$ & \\
\hline$S_{p k}(\mu m)$ & 0.78 & 0.25 & 0.75 & 0.12 & 0.16 & 0.24 & Valores Baixos \\
\hline$S_{k}(\mu m)$ & 0.6 & 0.29 & 1.90 & 0.29 & 0.66 & 0.65 & Valores Baixos \\
\hline$S_{\mathrm{vk}}(\mu \mathrm{m})$ & 0.19 & 0.26 & 1.18 & 0.12 & 0.19 & 0.18 & Valores Altos \\
\hline$M_{r 1}(\%)$ & 16.4 & 13.5 & 9.05 & 9.5 & 6.5 & 8.7 & - \\
\hline $\mathrm{M}_{\mathrm{r} 2}(\%)$ & 87.9 & 84.9 & 87.47 & 90 & 91 & 93 & - \\
\hline
\end{tabular}

A análise dos parâmetros funcionais, da curva da área de carregamento, indica que a superfície resultante possui boa área de contato, boa capacidade de carregamento e razoável capacidade de retenção de fluídos, uma vez que o valor do parâmetro $S_{v k}$ não apresentou valores altos para todas as condições testadas. $O$ valor do parâmetro assimetria das alturas $S_{\text {sk }}$, não se apresentou negativo em todas as condições testadas indicando que a superfície não possui boa capacidade de retenção de fluídos. O uso de inserto de geometria "wiper" pode ter influenciado os resultados. Uma análise com geometria convencional pode ser executada para averiguação da significância da influencia da geometria de ponta nos resultados da rugosidade superficial.

A visualização dos dados plotados tridimensionalmente com todas três variáveis envolvidas, também indica a influência que cada uma exerceu no resultado dos parâmetros de rugosidade. O método de interpolação utilizado foi o método polinomial de Akima. As Figuras 143 a 149 apresentam as superfícies de resposta em função dos parâmetros Velocidade de Corte $\left(V_{c}\right.$ em $\mathrm{m} / \mathrm{min}$ ) e Avanço ( $\mathrm{f}$ em $\mathrm{mm} / \mathrm{rot}$ ). Os círculos plotados indicam a média e o desvio padrão dos valores medidos.

É importante observar que os gráficos abaixo não devem ser comparados entre si, mas cada um representa uma função que pode ser agregada ao componente usinado em questão. O que deve ser avaliado é o grau de atribuição da função ao componente com base nos valores encontrados (por exemplo, maior ou menor capacidade de retenção de fluídos). 


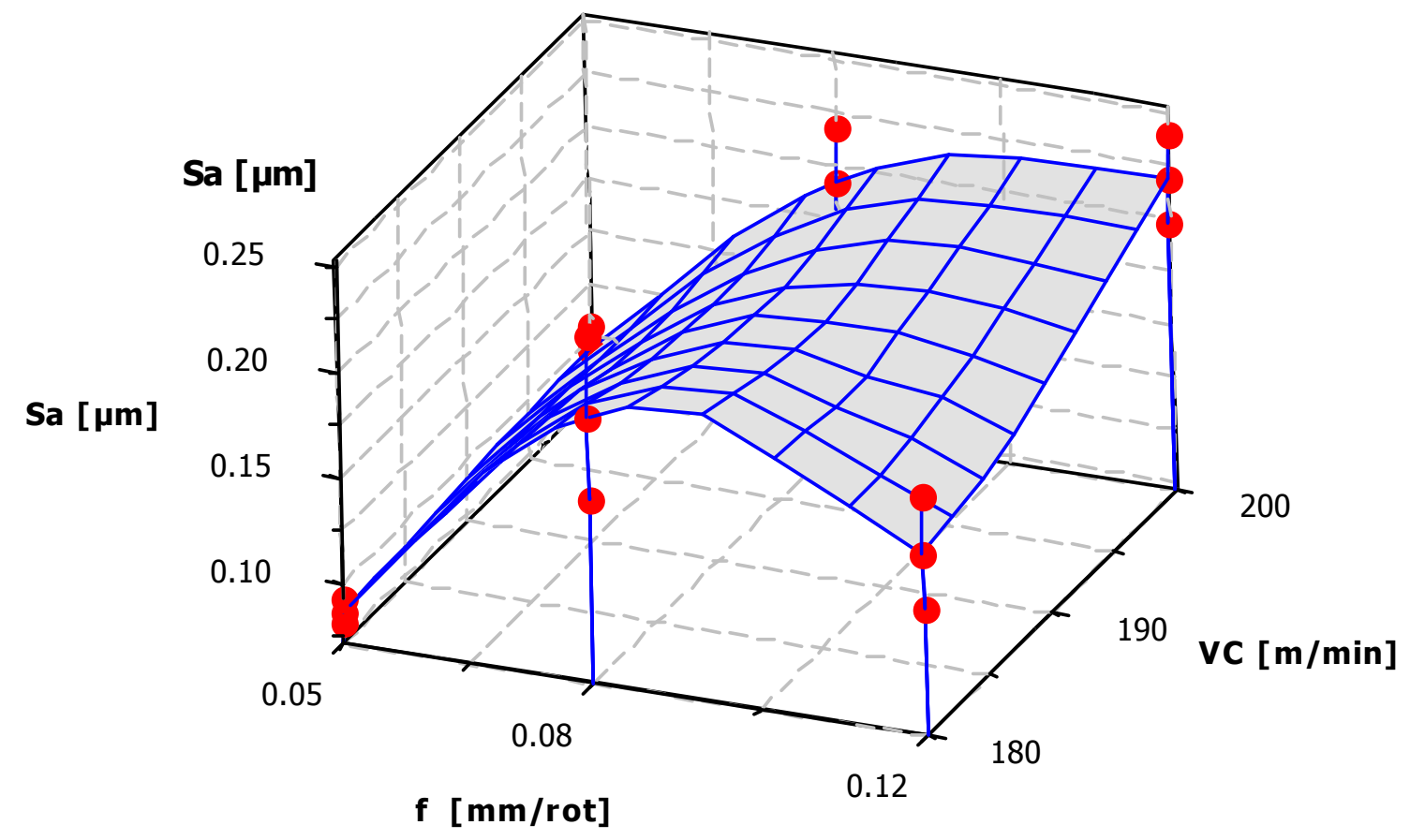

Figura 143. Rugosidade média aritmética em função da Velocidade de Corte e Avanço.

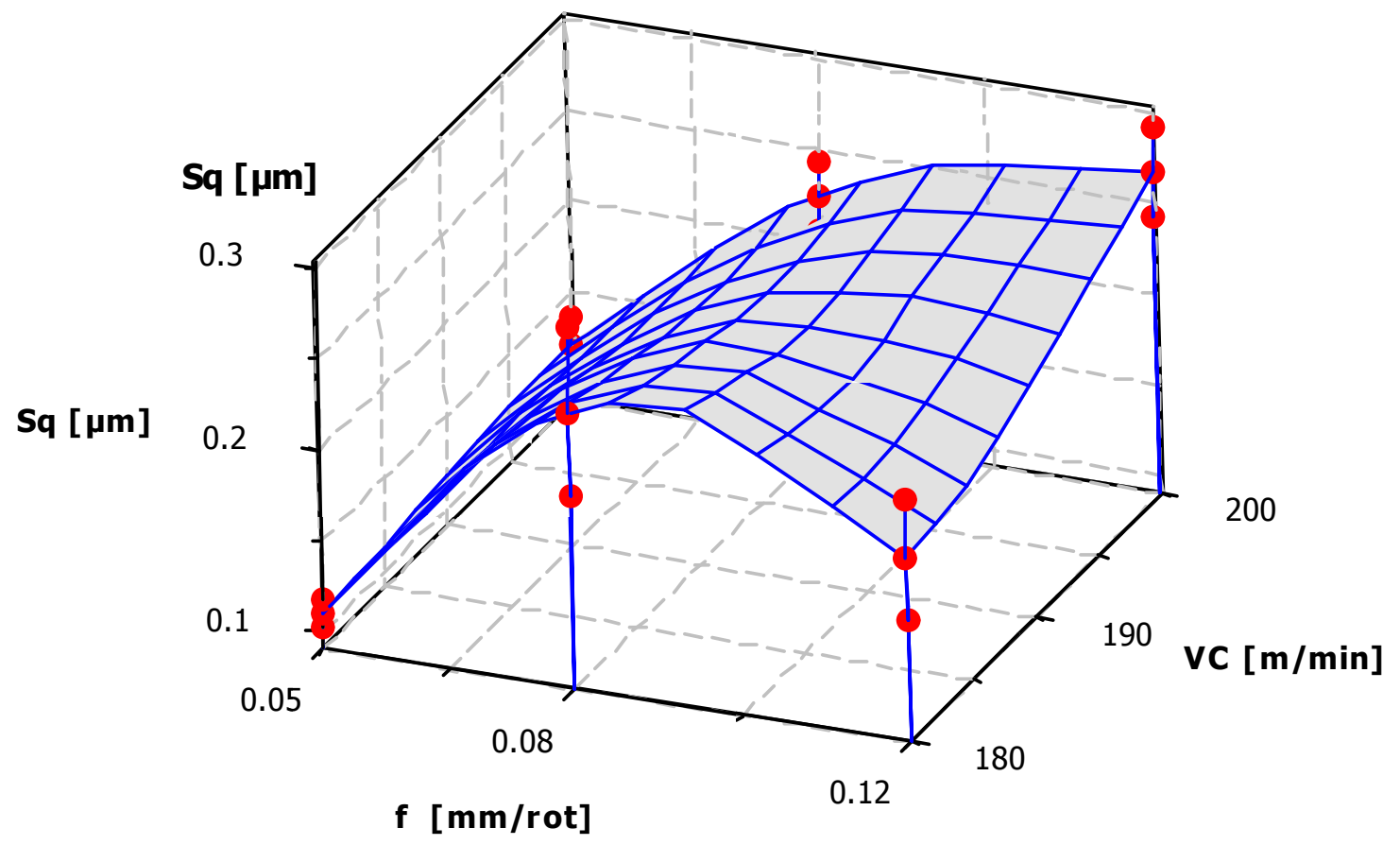

Figura 144. Rugosidade média quadrática em função da Velocidade de Corte e Avanço. 


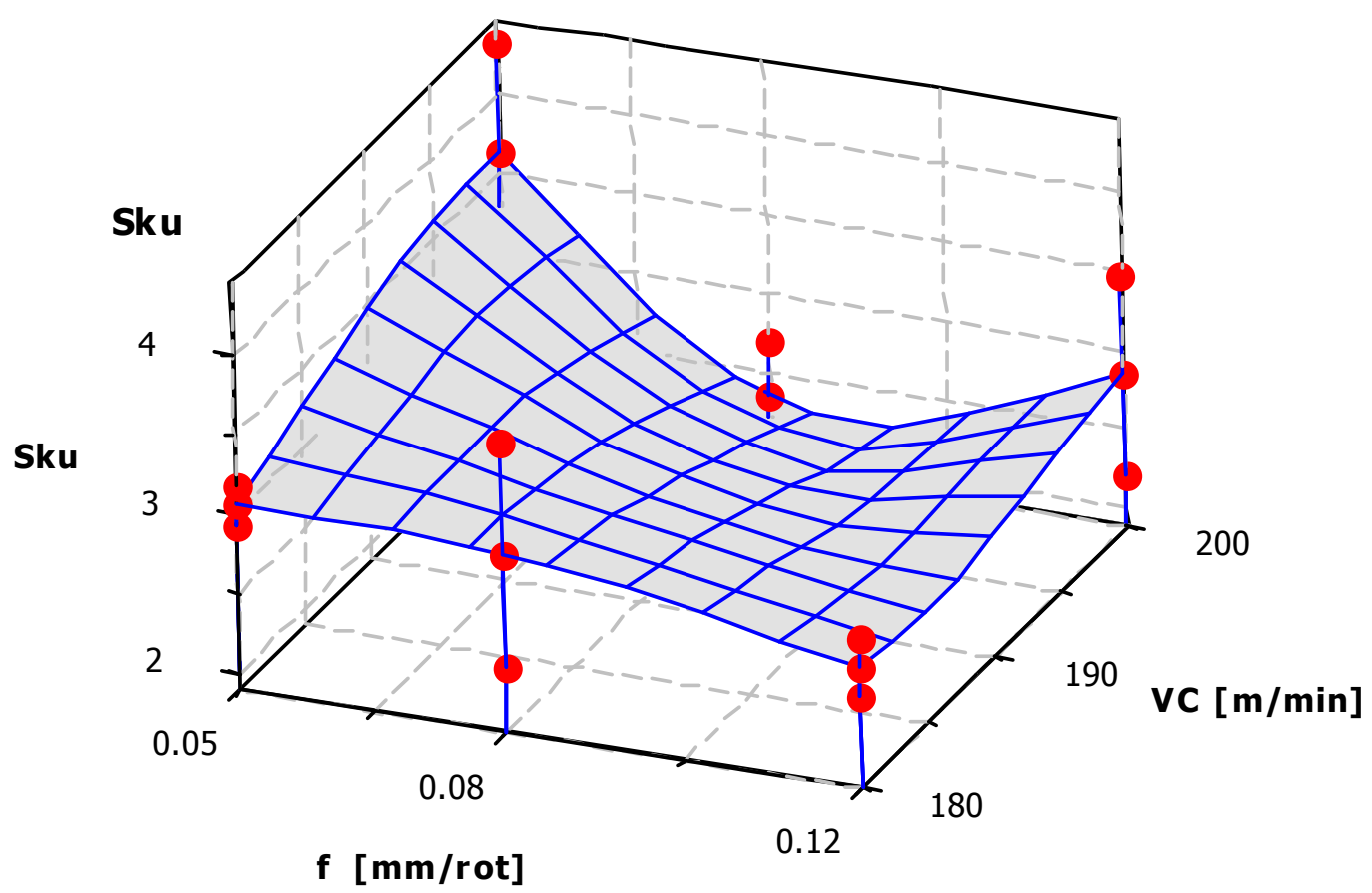

Figura 145. Curtose da Distribuição da rugosidade em função da Velocidade de Corte e Avanço.

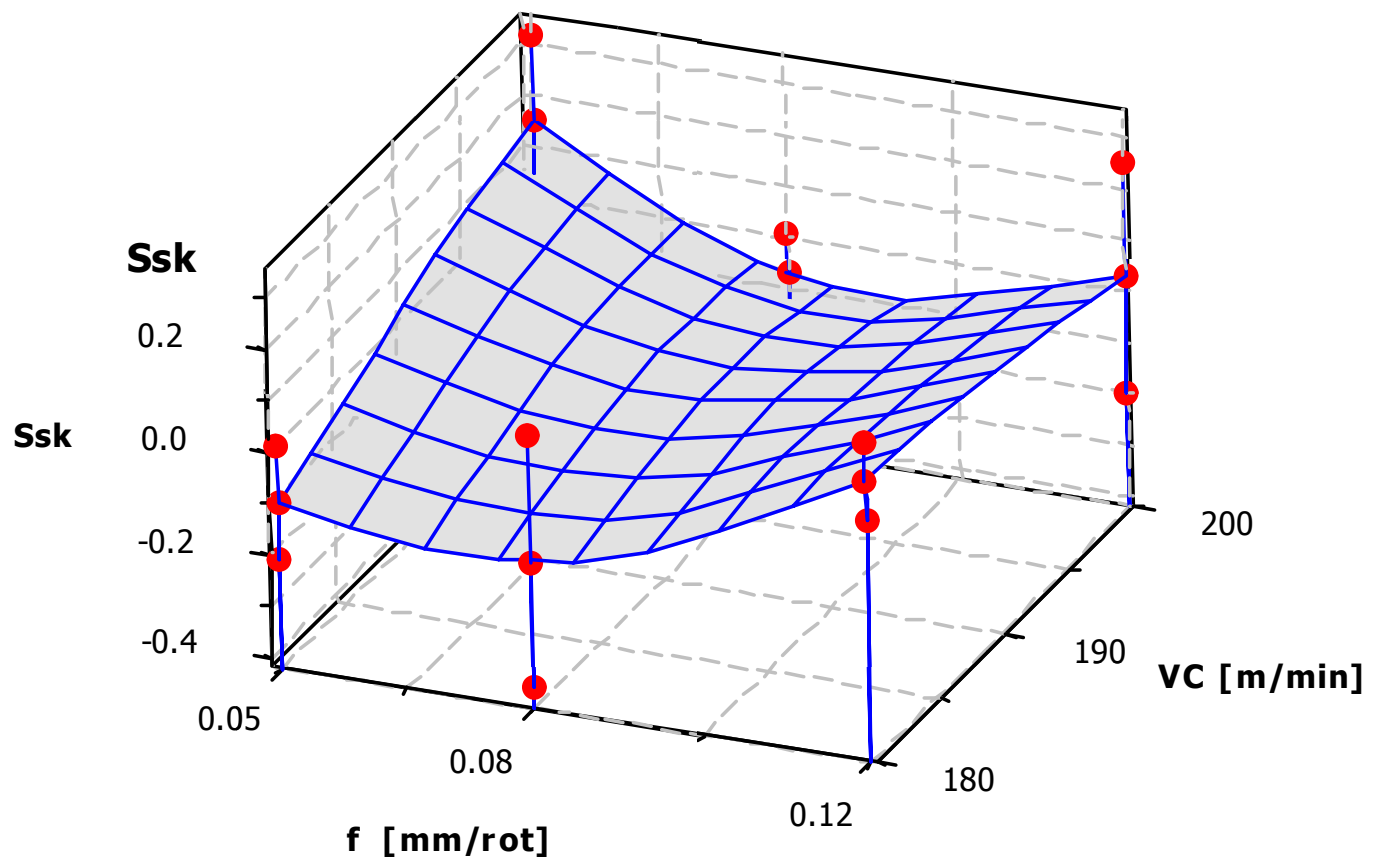

Figura 146. Assimetria da Distribuição da rugosidade em função da Velocidade de Corte e Avanço. 
As Figuras 147 a 149 apresentam a análise dos Parâmetros Funcionais da Distribuição das Alturas Baseados na Curva da Área de Carregamento.

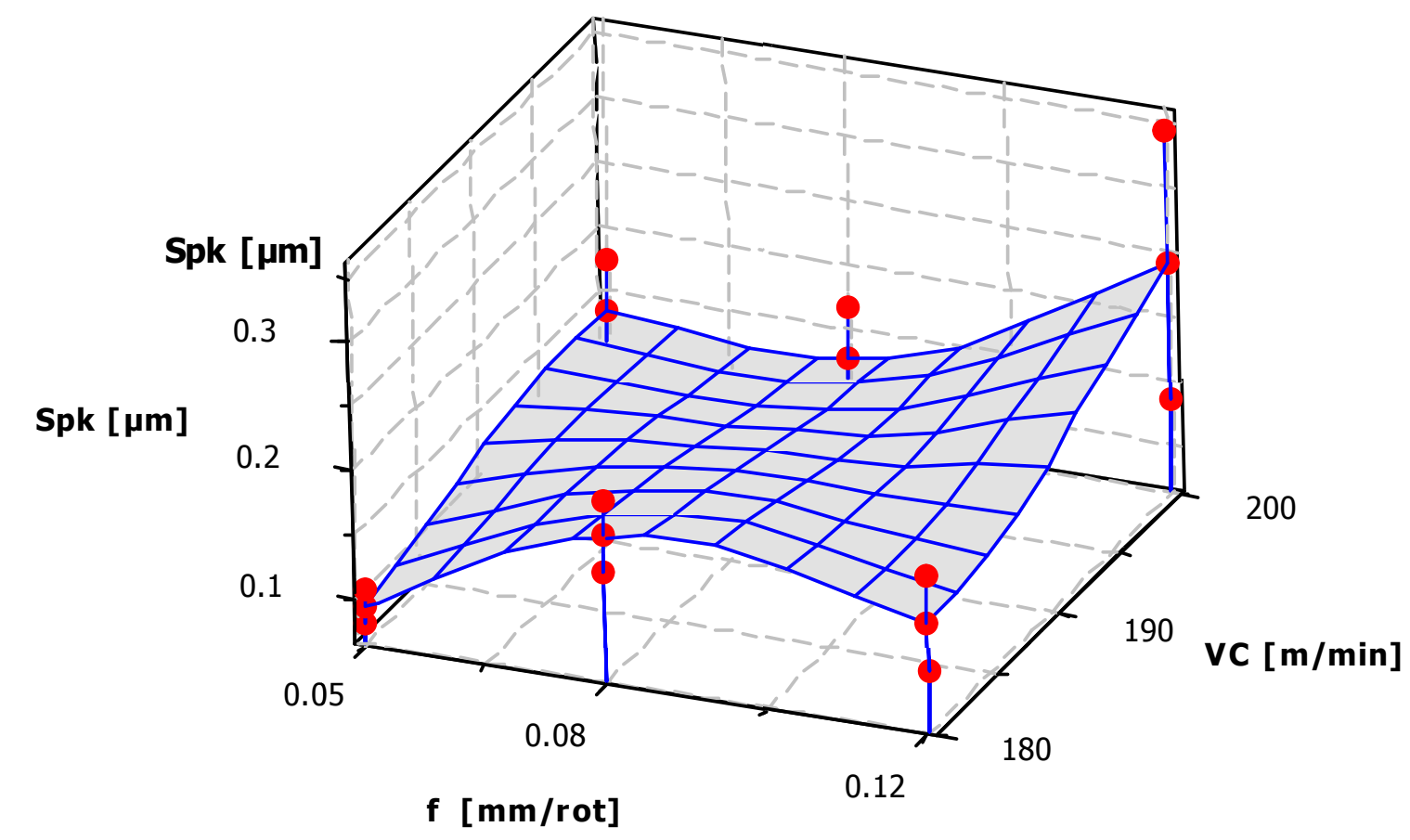

Figura 147. Altura reduzida dos picos em função da Velocidade de Corte e Avanço.

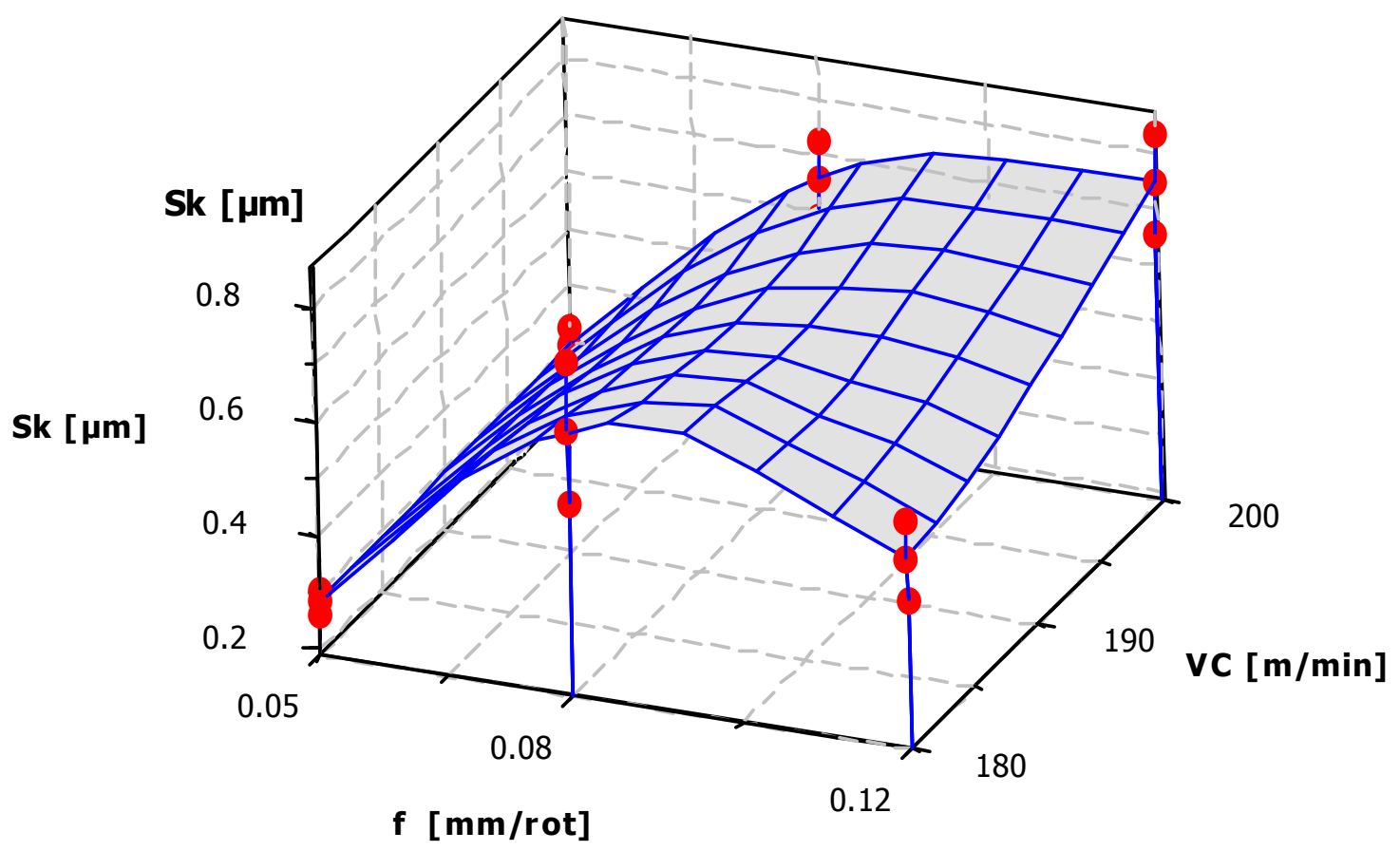

Figura 148. Rugosidade do núcleo em função da Velocidade de Corte e Avanço. 


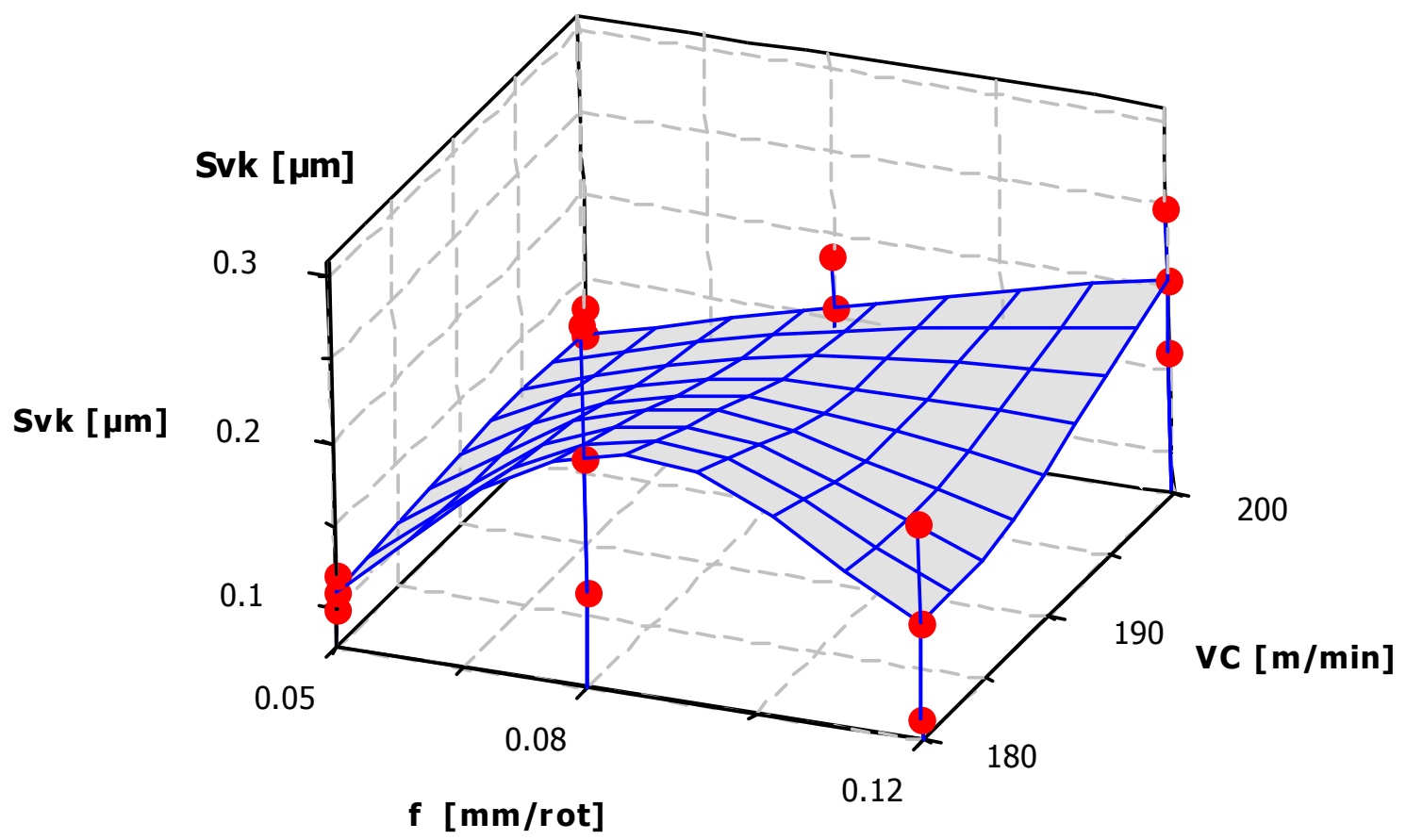

Figura 149. Profundidade reduzida dos vales em função da Velocidade de Corte e Avanço.

A analise gráfica, Figuras 116 a 121, da topologia é especialmente importante nos casos onde o processo ou as características finais não são totalmente conhecidos. Determinadas características são facilmente observadas visualizandose o padrão da superfície mapeada, ao invés, da abstração de um parâmetro somente. Exemplo do pressuposto é a possibilidade de visualizar a influência do avanço no número de picos/vales para a mesma área mapeada nas Figuras 116 a 121. Devido à característica do corte com aresta única do torneamento a superfície é composta por picos e vales bem definidos.

\subsection{Comparação com a Condição Retificada}

As Figuras 150 a 152 fazem uma comparação, entre o processo de torneamento de material endurecido em função do avanço e a retificação convencional. O teste de variância (ANOVA) com $95 \%$ de nível de confiança, indicou que o avanço é a variável mais significativa entre as interações com os parâmetros de rugosidade obtidos no torneamento, por este motivo utilizou-se as médias dos 
valores entre as velocidades de corte. Na Figura 150 é possível observar que os valores da rugosidade média aritmética $S_{a}$ são menores do que a condição retificada.

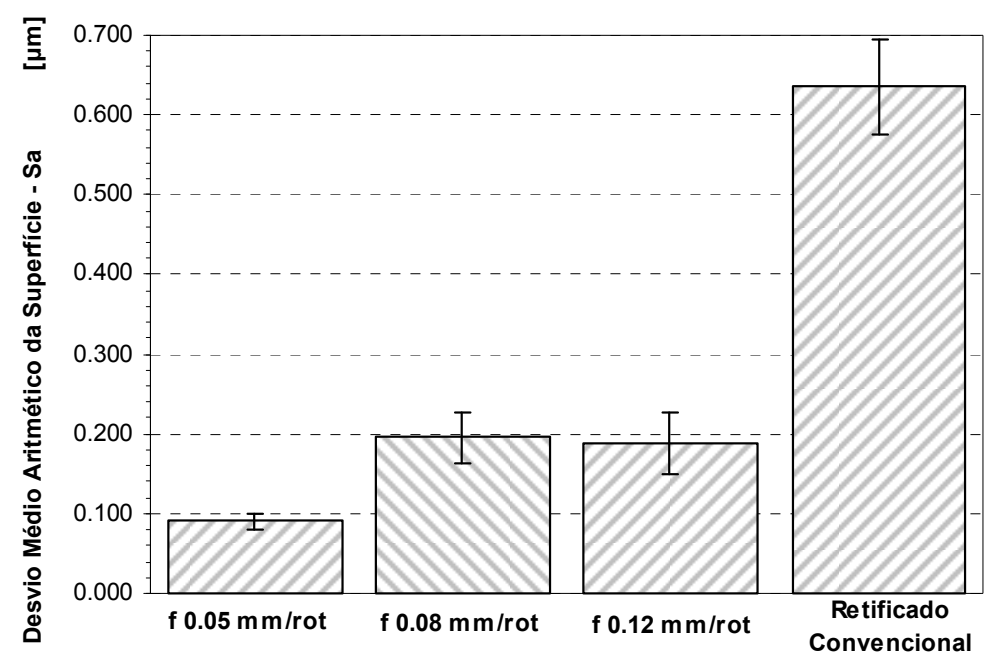

Figura 150. Comparação dos valores de $S_{a}$ para Torneamento duro e Retificação Convencional.

A rugosidade $S_{k u}$ (curtose) da condição retificada possui valor próximo a 5 enquanto que as condições torneadas possuem valores próximos a três (Figura 151). Valores superiores a três na curtose indicam superfícies com picos mais finos, mais susceptíveis ao desgaste prematuro, e valores inferiores a três indicam superfícies com menor tendência ao desgaste prematuro, portanto a superfície torneada possui uma melhor resistência ao desgaste prematuro.

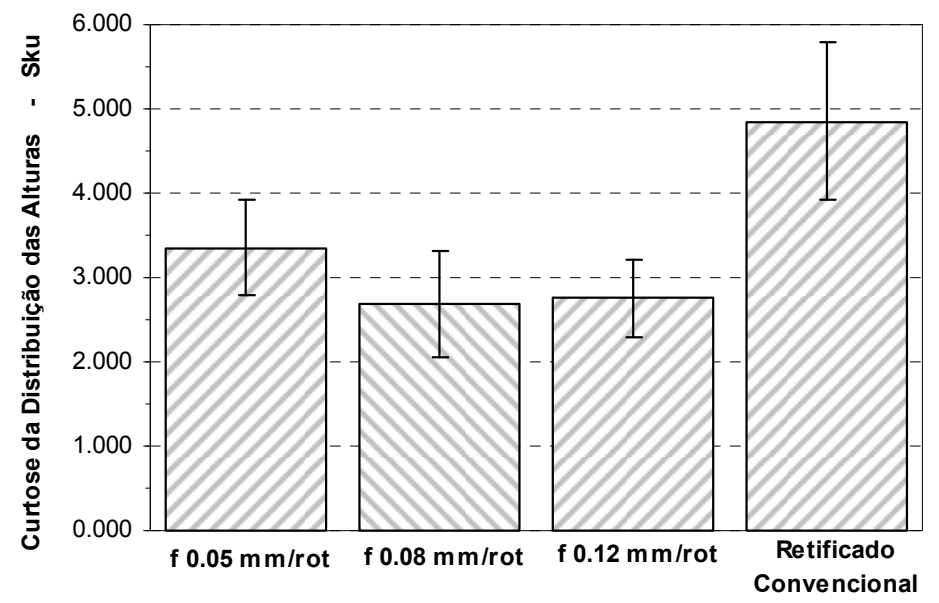

Figura 151. Comparação dos valores de $S_{k u}$ para Torneamento duro e Retificação Convencional. 
A rugosidade $S_{\text {sk }}$ (assimetria da distribuição das alturas) da condição retificada possui valor próximo a $-0,5$, enquanto que as condições torneadas possuem valores próximos a zero (Figura 152). Um valor negativo, na assimetria da distribuição das alturas, indica uma melhor condição de retenção de fluidos e melhor capacidade de carregamento, portanto a condição torneada não possui um bom desempenho neste aspecto. Porém, é importante observar que em uma das condições ( $f=0,08 \mathrm{~mm} / \mathrm{rot}$ ) seu valor se tornou negativo, portanto se esta função é importante para o desempenho da peça, os dados de usinagem podem ser trabalhados de forma conveniente a induzir a superfície apresentar valores negativos para este parâmetro.

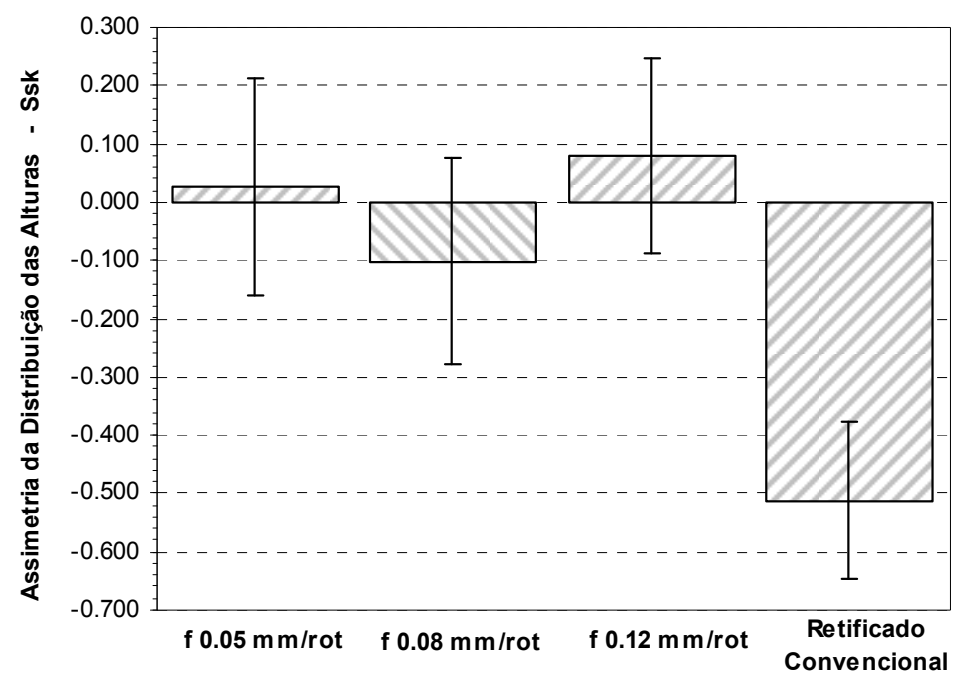

Figura 152. Comparação dos valores de $S_{s k}$ para Torneamento duro e Retificação Convencional.

\subsection{Camada de Material Afetada}

O perfil de dureza e as metalografias, executadas na camada das amostras, apresentam indícios da formação de CB ou alguma alteração de estrutura, devido ao processo de torneamento endurecido. Três amostras (com dados de corte $V_{c}=180 \mathrm{~m} / \mathrm{min} \times f=0.05 \mathrm{~mm} / \mathrm{rot}, \quad V_{c}=180 \mathrm{~m} / \mathrm{min} \quad x \quad f=0.12 \mathrm{~mm} / \mathrm{rot}$ e $V_{c}=200 \mathrm{~m} / \mathrm{min} \quad x$ $\mathrm{f}=0.12 \mathrm{~mm} / \mathrm{rot}$ ), apresentaram uma fina CB (aproximadamente $3 \mu \mathrm{m}$ ) que pode ser $\mathrm{o}$ início da formação efetiva de uma CMA. 
As análises executadas com o microscópio de varredura eletrônica não levantaram indícios significativos de camadas subsuperficiais alteradas.

Não foram detectadas alterações expressivas na dureza da camada subsuperficial, como mostra a Figura 141, o perfil de durezas levantado não apresentou significativas alterações, principalmente na região limítrofe da área transversal com a superfície.

É importante notar que, devido ao grau de aquecimento atingido na região superficial, podemos incorrer em modificações expressivas na camada cementada, que devem ser levadas em consideração para futuras análises com ferramentas desgastadas. 


\section{CONCLUSÕES}

A integridade superficial de componentes mecânicos fabricados em aço ABNT 8620 cementados, usinados com o processo de torneamento de material endurecido, pôde ser classificada através da analise de sua topografia superficial com análise dos parâmetros funcionais, medição das tensões residuais e análises de metalografias das camadas subsuperficiais. As principais conclusões referentes a este trabalho são apresentadas a seguir:

- O torneamento em material endurecido induziu tensão de compressão nas camadas das amostras cementadas, cuja condição original, era tensão residual de tração.

- Observou-se uma grande variação nos perfis de tensão residual após a usinagem, porém, o perfil de todas as amostras usinadas se encontrou na faixa de tensão de compressão.

- O torneamento em material endurecido tem a capacidade de introduzir maiores quantidades de tensão de compressão, seu valor máximo foi $-595 \mathrm{MPa}$, enquanto que na retificação foi $-111 \mathrm{MPa}$.

- A análise de variância da tensão residual nas amostras indicou uma significante interação com a variável avanço (f), e também se mostra significativa a interação entre as duas variáveis conjuntas (velocidade de corte e avanço ).

- O método do furo cego possibilitou o levantamento de um perfil de tensões para o sentido axial e circunferencial das amostras, indicando que o ponto de máximo valor compressivo foi atingido na profundidade média de $70 \mu \mathrm{m}$ $(\sigma=5 \mu \mathrm{m})$. 
- A tensão residual na superfície, obtida com o método da difração de raios-X, apresentou-se compressiva em todos os casos analisados com valores médios de -150 MPa a -520 MPa para o sentido circunferencial. Foi observada grande dispersão nos resultados de algumas amostras especialmente na amostra com dados de corte $V_{c}=200 \mathrm{~m} / \mathrm{min}$ e $\mathrm{f}=0,12 \mathrm{~mm} / \mathrm{rot}$.

- Em todos os casos de rugosidade estudados, os valores encontrados nas condições de torneamento em material endurecido se apresentaram mais baixos quando comparados com a situação de retificação.

- Os parâmetros assimetria da distribuição das alturas $S_{\text {sk }}$ e os parâmetros da curva da área de carregamento $S_{\mathrm{pk}}, S_{\mathrm{vk}}, \mathrm{M}_{\mathrm{r} 1}$ e $\mathrm{M}_{\mathrm{r} 2}$, apresentaram grande dispersão nos resultados. São parâmetros muitos sensíveis a qualquer variação na condição da superfície e refletem isto em uma grande dispersão quando dimensionados, provocando muitas vezes ambiguidade (Batalha e Stipkovic, 2001) na correlação funcional de seus resultados.

- A análise de variância indicou que o avanço (f) é, definitivamente, a variável mais significativa entre as interações com todos os parâmetros de rugosidade analisados.

- A análise dos parâmetros funcionais da curva da área de carregamento indica que a superfície resultante possui boa área de contato, boa capacidade de carregamento e razoável capacidade de retenção de fluidos uma vez que o valor do parâmetro $S_{\text {sk }}$ não apresentou valores negativos para todos os valores testados.

- Não foram detectadas alterações expressivas na camada cementada, principalmente na região limítrofe da área transversal com a superfície devido ao aquecimento e rápido resfriamento imposto pela usinagem. 
- A microscopia óptica possibilitou a visualização do início da formação de uma $\mathrm{CB}$ de aproximadamente $3 \mu \mathrm{m}$ nas amostras usinadas, porém, devido à baixa espessura da camada e a resolução da lente óptica utilizada não apresentar uma imagem clara em todas as amostras, não é possível afirmar a existência da CB em toda superfície.

- O perfil de durezas medido não apresentou significativas alterações, principalmente na região limítrofe da área transversal com a superfície, região crítica que sofre diretamente com o aquecimento e rápido resfriamento imposto pela usinagem.

- As metalografias obtidas pelo MEV não apresentaram indícios de grandes deformações na camada subsuperficial, não foi possível observar, nas regiões analisadas, nenhum tipo de CMMA ou CMTA.

- Os resultados obtidos na medição das rugosidades superficiais, apresentam coerência com os resultados de outros autores, isto indica que a técnica empregada neste estudo foi executada de forma coerente e os valores encontrados podem ser tomados como referência para futuras discussões. 


\section{SUGESTÕES PARA TRABALHOS FUTUROS}

- Investigar a correlação entre o desgaste da ferramenta de corte com a ocorrência de CB na superfície, pois o desgaste da ferramenta aumenta a temperatura no evento unitário do torneamento em material endurecido, o que induz ao aparecimento de CB.

- Estudar a influência de diferentes profundidades de corte $\left(a_{p}\right)$ nos resultados da tensão residual, pois como visto na revisão bibliográfica ainda não existe um consenso sobre sua influência nos valores encontrados.

- Estudar a vida da ferramenta em material cBN como função dos parâmetros de usinagem empregados visando a viabilização para produção de grandes lotes de peças.

- Estudar a influência na rugosidade de outras geometrias de corte de ferramentas além da geometria multiraio wiper, pois funcionalmente nem sempre uma baixa rugosidade é sinônimo de boa integridade superficial.

- Modelar o perfil de tensão residual em materiais endurecidos sujeitos à condição de torneamento. A compreensão do comportamento das tensões residuais é importante para melhorar o desempenho em relação à fadiga dos componentes torneados. 


\section{BIBLIOGRAFIA}

ABRÃO, A. M.; ASPINWALL, D. K. The surface integrity of turned and ground hardened bearing steel. Wear, 196, 1996, p. 279-284.

ABRÃO, A. M. Torneamento de aços endurecidos, Tecnologias avançadas de Manufatura. Cap. 5, Editora Novos Talentos, 2005, p. 89-103.

ABRÃO, A. M.; ASPINWALL, D. Pastilhas de PCBN e cerâmica facilitam e melhoram a usinagem de materiais duros. Máquinas e Metais, outubro 1995, p. 22-28.

ALMEIDA, C. H. D.; ABRÃO, A. M. Dimensional and geometric tolerances after machining case hardened AISI 5115 steel. International Journal for Manufacturing Science and Technology, V3 (2), 2001, p. 92-108.

ALTINTAS Y. Manufacturing Automation: metal cutting mechanics, machine tool vibrations and CNC design. Cambridge University Press, 2000, 283 p.

ASM Handbook. Heat Treating. American Society for Metals. 1991, v 4.

ASM Handbook. Friction, Lubrication and Wear Technology. American Society for Metals, 1991, v 18.

ASTM E18. Standard Test Methods for Rockwell Hardness of Metallic Materials. American Standard for Testing Metals, 2007.

ASTM E837. Determining Residual Stress by the Hole- Drilling-Stran-Gauge Method. American Standard for Testing Metals, 1985.

BATALHA, G. F.; STIPKOVIC FILHO, M.; Quantitative Characterization of the Surface topography of cold rolled sheets - new approaches and possibilities. Journal of Materials Processing Technology, Dublin - Irlanda, 113, 1, 2001, p. 732-8.

BAUMGARTEN, J. F. Cementação sólida empregando granulado elaborado a partir de carvão vegetal reciclado e ativador de $\mathrm{CaCo}_{3}$ ecologicamente correto, $93 \mathrm{p}$, Tese (Doutorado), Centro de Ciências Tecnológicas, Departamento de Engenharia Mecânica, Universidade do Estado de Santa Catarina, 2003.

BORDINASSI, E. C. Contribuição ao estudo da integridade superficial de um aço inoxidável super-duplex após usinagem, 221 p., Tese (Doutorado), Departamento de engenharia Mecânica, Escola Politécnica da USP, Universidade de São Paulo, São Paulo, 2006. 
BRINKSMEIER, E. et al. Residual Stresses - Measurement and causes in machining processes. Annals of the CIRP, v 31, 1982, p. 491-510.

CALLE, M. A. Análise numérico-computacional das tensões residuais induzidas pelo jateamento com granalha, 96 p, Dissertação (mestrado), Escola Politécnica da USP, Universidade de São Paulo, São Paulo, 2004.

CHOU, Y. K.; EVANS, C. J. Tool wear mechanism in continuous cutting of hardened tool steels. Wear, 212, 1997, p. 59-65.

COSTA, D. D. Análise dos parâmetros de torneamento de aços endurecidos, $110 \mathrm{p}$, Dissertação (Mestrado), Faculdade de Engenharia Mecânica, Universidade Estadual de Campinas, Campinas, 1993.

DAHLMAN, P.; GUNNBERG, F.; JACOBSON, M. The influence of rake angle, cutting feed and cutting depth on residual stresses in hard turning, Journal of Materials Processing Technology, 147, 2004, p. 181-184.

DAMASCENO, D. Análise das tensões residuais após torneamento e retificação do aço ABNT 52100 endurecido, 105p., Dissertação (Mestrado), Faculdade de Engenharia Mecânica, Universidade Estadual de Campinas, Campinas, 1993.

DELIJAICOV, S. Modelagem das tensões residuais no processo de torneamento duro de um aço 100CrMn6 e suas correlações com os esforços de corte, 183 p., Tese (Doutorado), Departamento de engenharia Mecânica, Escola Politécnica da USP, Universidade de São Paulo, São Paulo, 2004.

DIGITAL SURF. Catálogo de Produtos Industriais on-line, Disponível em: <http://www.digitalsurf.fr/en/mntsoft.php 1>. Acesso em: 28 maio 2008.

DINIZ, A. E.; OLIVEIRA, A. J. Hard turning of interrupted surfaces using CBN tools Journal of Materials Processing Technology, 195, 2008, p. 275-281.

DIN 50 190. Pruefung Einsatzgehaerteter Teile- Bestimung der Einsatzhaertungtiefe Eht. DEUTSCHES INSTITUT FUER NORMUNG.

FARIA, J. V.; MUNHOZ JUNIOR, D. Efeito da austenita retida nas propriedades de fadiga de aços cementados - uma breve revisão. III Seminário Brasileiro de Engrenagens, São Paulo, 1990, p. 163-183.

FARIAS, A. Relatório técnico industrial sobre retificação cilíndrica em processo centerless. São Paulo, 2007, p. 2, relatório apresentado à empresa Polimold Ind. S/A em 03/05/07. 
FIELD, M.; KAHLES, J. F. Review of Surface Integrity of Machined Components, Metcut Research Associates Inc. Cincinnati, Ohio. Annals of the CIRP, v 20, 1971, p. 153-163.

FIELD, M.; KAHLES, J. F. A Review of Measuring Methods for Surface Integrity, Metcut Research Associates Inc. Cincinnati, Ohio. Annals of the CIRP, v 21, 1972, p. 219-238.

FREITAS, E. S. R. Parâmetros topográficos para avaliação, caracterização e controle tribológicos de superfícies de engenharia. 118 p., Dissertação (Mestrado), Escola de Engenharia, Universidade de São Paulo, São Carlos, 2006.

GODDING, A. D. Liquid Carburizing and Cyaniding. ASM Handbook, Heat Treating, v 4, ASM International, 1991, p. 329-347.

GRZESIK, W.; RECH, J.; WANAT, T. Surface integrity of hardened steel parts in hybrid machining operations. Journal of Achievements in Materials and Manufacturing Engineering, v 18, 2006, p. 367-370.

GRZESIK, W.; RECH, J.; WANAT, T. Surface finish on hardened bearing steel parts produced by super hard and abrasive tools. International Journal of Machine Tools \& Manufacture, 47, 2007, p. 255-262.

GRZESIK, W. Machining of Hard Materials, Machining. In: Davim, J. P., Machining: Fundamentals and Recent Advances, London, Springer-Verlag London Limited, 2008a, p. 98-126.

GRZESIK, W. Influence of tool wear on surface roughness in hard turning using differently shaped ceramic tools. Wear, 265, 2008b, p. 327-335.

GRIFFITHS, B. Manufacturing Surface Technology. London, Penton Press, 2001, p. 233.

GUNNBERG, F.; ESCURSELL, M.; JACOBSON, M. The influence of cutting parameters on residual stresses and surface topography during hard turning of $18 \mathrm{MnCr} 5$ Case Carburized steel. Journal of Materials Processing Technology, 174, 2006, p. 82-90.

GUO, Y.B.; YEN, D.W. "Hard Turning versus Grinding - The Effect of ProcessInduced Residual Stress on Rolling Contact," Wear, 256, 2004, p. 393-399.

GUO, Y.B.; BARKEY, M. E. Modeling of rolling contact fatigue for hard machined components with process-induced residual stress. International Journal of Fatigue, 26, 2004, p. 605-613. 
GUO, Y. B.; WEN, Q.; WOODBURY, K. A. Dynamic Material Behavior Modeling Using Internal State Variable Plasticity and Its Application in Hard Machining Simulations. Journal of Manufacturing Science and Engineering, 2006, v 128, p. 749759.

HASHIMOTO, F.; GUO, Y.B.; WARREN, A.W. Surface Integrity Difference between Hard Turned and Ground Surfaces and Its Impact on Fatigue Life. Annals of the CIRP, 55, 1, 2006, p. 4.

HUA, J.; UMBRELLO, D.; SHIVPURI, R. Investigation of cutting conditions and cutting edge preparations for enhanced compressive subsurface residual stress in the hard turning of bearing steel. Journal of Materials Processing Technology, 171, 2006, p. 180-187.

ISO 13565-2. Geometrical product Specifications Profile Method, Surfaces having stratified functional properties - Part 2: Height characterization using the linear material ratio curve, 1996.

JAVIDI, A.; RIEGER, U.; EICHLSEDER, W. The effect of machining on the surface integrity and fatigue life. International Journal of Fatigue, 30, 2008, p. 2050-2055.

KISHAWY, H.A.; ELBESTAWI, M.A. Effects of process parameters on material side flow during hard turning. International Journal of Machine Tools \& Manufacture, 39, 1999 , p. 1017-1030.

KOENIG, W.; KLINGER, M.; LINK, R. Machining hard materials with geometrically defined cutting edges - field of applications and limitations. Annals of the CIRP, $v 39$, 1990 , p. 61-64.

LAMPMAN, S. Introduction to Surface Hardening of Steels. ASM Handbook Heat treating, v 4, ASM International, 1991, p. 607-625.

LIMA, F. E. Características do processo de torneamento de materiais endurecidos. 118p. Tese (Doutorado) - Faculdade de Engenharia Mecânica, Universidade de Campinas. Campinas 2001.

LIMA, N. B. Influência da textura em medidas de tensão residual, 105 p., Tese (Doutorado), Instituto de Pesquisas Energéticas e Nucleares, Universidade de São Paulo, São Paulo, 1991.

LIN, H.M.; LIAO, Y.S.; WEI, C.C. Wear behavior in turning high hardness alloy steel by CBN tool. Wear, 264, 2008, p. 679-684.

MACHERAUCH, E. Praktikum in Werkstoffkunde. Ed. Vieweg, Braunschweig/ Wiesbaden, Alemanha, 10ª ed., (V39 - Einsatzhärten), 1992, 173 p. 
MARIN, I. V.; DINU-STANCIULESCU, G.; STOICA, G. Aspects théoriques et expérimentaux concernant l'état des surfaces issus d'un procédé de tournage. The annals of university "Dunărea de Jos" of Galati Fascicle VIII, TRIBOLOGY, 2003, p. 73-79.

MARTINS, C. O. D.; STROHAECKER, T. R.; ROCHA, A. S.; HIRSCH, T. K.Comparação entre Técnicas de Análise de Tensões Residuais em Anéis de Rolamento do Aço ABNT 52100. Revista Matéria, v 9, 2004, p. 20-28.

MATSUMOTO, Y.; HASHIMOTO, F.; LAHOTI G. Surface integrity generated by precision hard turning. Annals of the CIRP, v 48, 1999, p. 59-62.

METCUT RESEARCH ASSOCIATES. Machining Data Handbook. Ohio, Institurtenfor advanced manufacturing Sciences, $3^{\mathrm{a}}$ ed, 1980.

METALS Handbook. Metals Handbook Desk Edition. ASM International Handbook Committee, Davis. J. R., $2^{a}$ ed., 1998, 2571 p.

MICRO PHOTONICS. Catálogo de Produtos Industriais on-line, Disponível em: <http://www.microphotonics.com/micromeasure.html>. Acesso em: 08 nov. 2007.

MUMMERY, L. Surface Texture Analysis the handbook, 106 p, 1992.

OGATA, H. T. S. Determinação da influência das tensões residuais nas propriedades de fadiga em aço SAE 8620 processado com diferentes profundidades de camada de cementação, 143 p., Dissertação (Mestrado), Universidade Federal do Paraná, Curitiba, 2003.

OEZEL, T.; KARPAT, Y.; FIGUEIRA, L.; DAVIM, J.P. Modelling of surface finish and tool flank wear in turning of AISI D2 steel with ceramic wiper inserts. Journal of Materials Processing Technology, 189, 2007, p. 192-198.

PAVEL, R.; MARINESCU, I.; DEIS, M.; PILLAR, J. Effect of tool wear on surface finish for a case of continuous and interrupted hard turning. Journal of Materials Processing Technology, 170 , 2005, p. 341-349.

POLIMOLD. Catálogo de Produtos Industriais on-line, Disponível em: <http://www.polimold.com.br>. Acesso em: 07 jul. 2008.

POULACHON, G.; MOISAN, A.; JAWAHIR, I.S. Tool-wear mechanisms in hard turning with polycrystalline cubic boron nitride tools. Wear, 250, 2001, p. 576-586.

POULACHON, G.; MOISAN, A. A contribution to the study of the of the cutting Mechanisms during high speed machining. Annals of the CIRP, 1998, v 47, p. 73-76. 
PREVĖY, P.S. Current applications of X-Ray diffraction residual stress measurements. ASTM International, Materials Park, 1996, p. 103-110.

QIAN, L.; HOSSAN, M. R. Effect on cutting force in turning hardened tool steels with cubic boron nitride inserts. Journal of Materials Processing Technology, 191, 2007, p. 274-278.

RECH, J.; MOISAN, A. Surface Integrity in finish hard turning of case-hardened steels. International Journal of Machine and Manufacture, 43, 2003, p. 543-550.

RECH et al. Characterization and modelling of the residual stresses induced by belt finishing on an AISI52100 hardened steel. Journal of Materials Processing Technology, 2008, No Prelo.

SECO. Secomax PCBN Technical Guide. SECO TOOLS AB, Sweden, Grafiska byran/db Oerebro, 2003.

SCHWACH, D. W.; GUO, Y. B. A fundamental study on the impact of surface integrity by hard turning on rolling contact fatigue. Transactions of NAMRI/RI/SME, 33,2005 , p. 541-548.

SHAW, M.C. Metal cutting Principles. Oxford, Oxford University Press, 2007, p. 672.

STICKELS, C.A. Gas Carburizing of Steels. ASM Handbook Heat treating, v 4, ASM International, 1991, p. 721-748.

STOUT, K. J.; SULLIVAN, P.J.; DONG, W.P.; MAINSAH, E.; LUO, N.; MATHIA, T.; ZAHOUANI, $\mathrm{H}$. The development of methods for the characterization of roughness in three dimensions. University of Birmingham, Inglaterra, University of Birmingham Press, 1993, p. 359.

TAYLOR HOBSON. Catálogo de Produtos Industriais on-line, Disponível em: <http://www.taylor-hobson.com/en/surface-profilers/>. Acesso em: 08 nov. 2007.

THIELE J.D.; MELKOTE S.N. The effect of tool edge geometry on workpiece subsurface deformation and through-thickness residual stresses for hard turning of AISI52100. Trans NAMRI/SME 27, 1999, p. 135-140.

TOENSHOFF, H.K.; ARENDT, C.; AMOR, R. Cutting of hardened steel. Ann. CIRP 49/2, 2000, p. 547-566.

UMBRELLO, D.; AMBROGIO, G.; FILICE, L.; SHIVPURI, R. An ANN approach for predicting subsurface residual stresses and the desired cutting conditions during hard turning. Journal of Materials Processing Technology, 189, 2007, p. 143-152. 
UBM CORPORATION. Catálogo de Produtos Industriais on-line, Disponível em: <www.ubmusa.com>. Acesso em: 08 nov. 2007.

VAN VLACK, L. H. Princípios de Ciências dos Materiais, São Paulo, Editora Edgard Blücher Ltda, $4^{a}$ ed., 1971,.

VISHAY-MEASUREMENTS GROUP. Catálogo de Produtos Industriais on-line, Disponível em: <http://www.vishay.com/strain-gages/>. Acesso em: 28 nov. 2007.

WAIKAR, R.A.; GUO, Y.B. A comprehensive characterization of 3D surface topography induced by hard turning versus grinding. Journal of Materials Processing Technology, 197, 2008, p. 189-199.

WARREN, A. W.; GUO, Y. B. The impact of surface integrity by hard turning versus grinding on rolling contact fatigue - Part I: Comparison of fatigue life and acoustic emission signals. Fatigue and Fracture Engineering Material Structure Journal, v 30, 2007, p. 698-711.

WHITEHOUSE, D. J. The Parameter Rash - Is There a Cure? Wear, 83, 1982, p. 7578.

YA. M.; XING, Y.; DAÍ, F.; LU, K.; LU, J. Study of residual stress in surface nanosttructured AISI 316L stainless steel. Surface \& Coatings Technology, v 168, 2003, p. 148-155. 


\section{ANEXOS}

\subsection{ANEXO - A: Condições do experimento de usinagem}

Tabela 17. Parâmetros de corte tabelados e associados.

\begin{tabular}{|c|c|c|}
\hline Amostra & VC $\mathbf{~} /$ min & f $\mathbf{~ m} /$ rot \\
\hline $\mathbf{1 1}$ & 180 & 0.08 \\
\hline $\mathbf{1 2}$ & 180 & 0.08 \\
\hline $\mathbf{1 3}$ & 180 & 0.08 \\
\hline $\mathbf{1 4}$ & 180 & 0.08 \\
\hline $\mathbf{1 5}$ & 180 & 0.08 \\
\hline $\mathbf{1 6}$ & 180 & 0.08 \\
\hline $\mathbf{1 7}$ & 180 & 0.08 \\
\hline $\mathbf{1 8}$ & 180 & 0.08 \\
\hline $\mathbf{1 9}$ & 180 & 0.08 \\
\hline $\mathbf{2 0}$ & 180 & 0.08 \\
\hline $\mathbf{2 1}$ & 180 & 0.08 \\
\hline $\mathbf{2 2}$ & 180 & 0.08 \\
\hline $\mathbf{2 3}$ & 180 & 0.08 \\
\hline $\mathbf{2 4}$ & 180 & 0.08 \\
\hline $\mathbf{2 5}$ & 180 & 0.08 \\
\hline $\mathbf{2 6}$ & 180 & 0.08 \\
\hline $\mathbf{2 7}$ & 180 & 0.08 \\
\hline $\mathbf{2 8}$ & 180 & 0.08 \\
\hline $\mathbf{2 9}$ & 180 & 0.08 \\
\hline $\mathbf{3 0}$ & 180 & 0.08 \\
\hline $\mathbf{3 1}$ & 180 & 0.08 \\
\hline $\mathbf{3 2}$ & 180 & 0.08 \\
\hline $\mathbf{3 3}$ & 180 & 0.08 \\
\hline $\mathbf{3 4}$ & 180 & 0.08 \\
\hline $\mathbf{3 5}$ & 180 & 0.08 \\
\hline $\mathbf{3 6}$ & 180 & 0.08 \\
\hline $\mathbf{3 7}$ & 180 & 0.08 \\
\hline $\mathbf{3 8}$ & 180 & 0.08 \\
\hline $\mathbf{3 9}$ & 180 & 0.08 \\
\hline $\mathbf{4 0}$ & 180 & 0.08 \\
\hline $\mathbf{4 1}$ & 200 & 0.05 \\
\hline $\mathbf{4 2}$ & 200 & 0.05 \\
\hline $\mathbf{4 3}$ & 200 & 0.05 \\
\hline $\mathbf{4 4}$ & 200 & 0.05 \\
\hline $\mathbf{4 5}$ & 200 & 0.05 \\
\hline $\mathbf{4 6}$ & 200 & 0.05 \\
\hline $\mathbf{4 7}$ & 200 & 0.05 \\
\hline $\mathbf{4 9}$ & 200 & 0.05 \\
\hline $\mathbf{5 0}$ & 200 & 0.05 \\
\hline & & 0.05 \\
\hline
\end{tabular}

\begin{tabular}{|c|c|c|}
\hline Amostra & $\mathrm{VC} \mathrm{m} / \mathrm{min}$ & $\mathrm{f} \mathrm{mm} / \mathrm{rot}$ \\
\hline 51 & 200 & 0.08 \\
\hline 52 & 200 & 0.08 \\
\hline 53 & 200 & 0.08 \\
\hline 54 & 200 & 0.08 \\
\hline 55 & 200 & 0.08 \\
\hline 56 & 200 & 0.08 \\
\hline 57 & 200 & 0.08 \\
\hline 58 & 200 & 0.08 \\
\hline 59 & 200 & 0.08 \\
\hline 60 & 200 & 0.08 \\
\hline 61 & 200 & 0.12 \\
\hline 62 & 200 & 0.12 \\
\hline 63 & 200 & 0.12 \\
\hline 64 & 200 & 0.12 \\
\hline 65 & 200 & 0.12 \\
\hline 66 & 200 & 0.12 \\
\hline 67 & 200 & 0.12 \\
\hline 68 & 200 & 0.12 \\
\hline 69 & 200 & 0.12 \\
\hline 70 & 200 & 0.12 \\
\hline 71 & 180 & 0.12 \\
\hline 72 & 180 & 0.12 \\
\hline 73 & 180 & 0.12 \\
\hline 74 & 180 & 0.12 \\
\hline 75 & 180 & 0.12 \\
\hline 76 & 180 & 0.12 \\
\hline 77 & 180 & 0.12 \\
\hline 78 & 180 & 0.12 \\
\hline 79 & 180 & 0.12 \\
\hline 80 & 180 & 0.12 \\
\hline 91 & 180 & 0.05 \\
\hline 92 & 180 & 0.05 \\
\hline 93 & 180 & 0.05 \\
\hline 94 & 180 & 0.05 \\
\hline 95 & 180 & 0.05 \\
\hline 96 & 180 & 0.05 \\
\hline 97 & 180 & 0.05 \\
\hline 98 & 180 & 0.05 \\
\hline 99 & 180 & 0.05 \\
\hline 100 & 180 & 0.05 \\
\hline
\end{tabular}


9.2 ANEXO - B:Tensão Residual pelo método do furo cego

Tabela 18. Resultados de medição de tensão residual com o método de furo cego.

\begin{tabular}{|c|c|c|c|c|c|c|c|}
\hline VC180 m/min - f $0.05 \mathrm{~mm} / \mathrm{rot}$ & \multicolumn{6}{|c|}{ Metodo Integral de Tensão (X esta na direçao 1 do extensômetro) } & \multirow{3}{*}{$\begin{array}{c}\text { Cisalh XY } \\
\mathrm{MPa} \\
\end{array}$} \\
\hline Profundidade & Tensão Max & Tensão Min & Max Cisalh & beta & Tensão X & Tensão Y & \\
\hline$\square \mathrm{m}$ & $\mathrm{MPa}$ & $\mathrm{MPa}$ & $\mathrm{MPa}$ & graus & $\mathrm{MPa}$ & $\mathrm{MPa}$ & \\
\hline 13 & 42 & -375 & 208 & -43 & -150 & -183 & 208 \\
\hline 50 & -63 & -488 & 212 & -38 & -226 & -325 & 207 \\
\hline 70 & -72 & -501 & 215 & -35 & -211 & -362 & 201 \\
\hline 90 & -59 & -469 & 205 & -32 & -175 & -352 & 185 \\
\hline 110 & -63 & -423 & 180 & -30 & -151 & -334 & 155 \\
\hline 130 & -49 & -337 & 144 & -26 & -106 & -280 & 114 \\
\hline 153 & -26 & -242 & 108 & -20 & -51 & -216 & 70 \\
\hline VC180 m/min - f $0.08 \mathrm{~mm} / \mathrm{rot}$ & \multicolumn{6}{|c|}{ Metodo Integral de Tensão (X esta na direçao 1 do extensômetro) } & \\
\hline Profundidade & Tensão Max & Tensão Min & Max Cisalh & beta & Tensão X & Tensão Y & Cisalh $X Y$ \\
\hline$\square \mathrm{m}$ & \begin{tabular}{|c|}
$\mathrm{MPa}$ \\
\end{tabular} & $\mathrm{MPa}$ & $\mathrm{MPa}$ & degrees & $\mathrm{MPa}$ & $\mathrm{MPa}$ & $\mathrm{MPa}$ \\
\hline 13 & -84 & -384 & 150 & 61 & -313 & -155 & -128 \\
\hline 50 & -225 & -346 & 61 & 42 & -280 & -291 & -60 \\
\hline 70 & -223 & -337 & 57 & -2 & -223 & -337 & 5 \\
\hline 90 & -138 & -309 & 85 & -22 & -163 & -284 & 60 \\
\hline 110 & -24 & -261 & 118 & -34 & -100 & -185 & 111 \\
\hline VC180 m/min - f $0.12 \mathrm{~mm} / \mathrm{rot}$ & \multicolumn{6}{|c|}{ Metodo Integral de Tensão (X esta na direçao 1 do extensômetro) } & \\
\hline Profundidade & Tensão Max & Tensão Min & Max Cisalh & beta & Tensão X & Tensão Y & Cisalh XY \\
\hline$\square \mathrm{m}$ & \begin{tabular}{|c|}
$\mathrm{MPa}$ \\
\end{tabular} & $\mathrm{MPa}$ & $\mathrm{MPa}$ & degrees & $\mathrm{MPa}$ & $\mathrm{MPa}$ & $\mathrm{MPa}$ \\
\hline 13 & -236 & -330 & 47 & -67 & -315 & -250 & 34 \\
\hline 50 & -391 & -502 & 56 & -63 & -479 & -415 & 46 \\
\hline 70 & -344 & -484 & 70 & -58 & -444 & -384 & 63 \\
\hline 90 & -179 & -371 & 96 & -53 & -301 & -248 & 92 \\
\hline 110 & -55 & -323 & 134 & -50 & -211 & -168 & 132 \\
\hline 130 & 1 & -341 & 171 & -47 & -185 & -156 & 170 \\
\hline 153 & 76 & -310 & 193 & -46 & -124 & -110 & 193 \\
\hline 173 & 163 & -257 & 210 & -45 & -46 & -48 & 210 \\
\hline VC200 m/min - f $0.05 \mathrm{~mm} / \mathrm{rot}$ & \multicolumn{6}{|c|}{ Metodo Integral de Tensão (X esta na direçao 1 do extensômetro) } & \\
\hline Profundidade & Tensão Max & Tensão Min & Max Cisalh & beta & Tensão X & Tensão Y & Cisalh XY \\
\hline$\square \mathrm{m}$ & \begin{tabular}{|c|}
$\mathrm{MPa}$ \\
\end{tabular} & $\mathrm{MPa}$ & $\mathrm{MPa}$ & degrees & $\mathrm{MPa}$ & $\mathrm{MPa}$ & $\mathrm{MPa}$ \\
\hline 13 & -153 & -330 & 89 & 61 & -279 & -166 & -75 \\
\hline 50 & -380 & -747 & 184 & 55 & -504 & -362 & -173 \\
\hline 70 & -450 & -892 & 221 & 54 & -595 & -438 & -210 \\
\hline 90 & -355 & -696 & 170 & 56 & -542 & -388 & -159 \\
\hline 110 & -226 & -356 & 65 & 67 & -440 & -299 & -46 \\
\hline 130 & -89 & -199 & 55 & -59 & -366 & -246 & 48 \\
\hline 153 & -11 & -124 & 57 & -49 & -331 & -230 & 56 \\
\hline 173 & -33 & -49 & 8 & 13 & -303 & -225 & -3 \\
\hline VC200 m/min - f $0.08 \mathrm{~mm} / \mathrm{rot}$ & \multicolumn{6}{|c|}{ Metodo Integral de Tensão (X esta na direçao 1 do extensômetro) } & \\
\hline Profundidade & Tensão Max & Tensão Min & Max Cisalh & beta & Tensão X & Tensão Y & Cisalh $\mathrm{XY}$ \\
\hline$\square \mathrm{m}$ & \begin{tabular}{|c|}
$\mathrm{MPa}$ \\
\end{tabular} & $\mathrm{MPa}$ & $\mathrm{MPa}$ & degrees & $\mathrm{MPa}$ & $\mathrm{MPa}$ & $\mathrm{MPa}$ \\
\hline 13 & -50 & -121 & 36 & 29 & -67 & -104 & -30 \\
\hline 50 & -85 & -217 & 66 & 37 & -133 & -169 & -64 \\
\hline 70 & -82 & -246 & 82 & 39 & -147 & -181 & -80 \\
\hline 90 & -41 & -190 & 74 & 39 & -100 & -131 & -73 \\
\hline 110 & -2 & -101 & 50 & 38 & -39 & -64 & -48 \\
\hline 130 & 21 & -26 & 24 & 33 & 8 & -12 & -22 \\
\hline VC200 m/min - f $0.12 \mathrm{~mm} / \mathrm{rot}$ & \multicolumn{6}{|c|}{ Metodo Integral de Tensão (X esta na direçao 1 do extensômetro) } & \\
\hline Profundidade & Tensão Max & Tensão Min & Max Cisalh & beta & Tensão X & Tensão $Y$ & Cisalh XY \\
\hline$\square \mathrm{m}$ & $\mathrm{MPa}$ & $\mathrm{MPa}$ & $\mathrm{MPa}$ & degrees & $\mathrm{MPa}$ & $\mathrm{MPa}$ & $\mathrm{MPa}$ \\
\hline 13 & -102 & -299 & 98 & 61 & -253 & -147 & -83 \\
\hline 50 & -189 & -397 & 104 & 66 & -363 & -223 & -77 \\
\hline 70 & -217 & -419 & 101 & 68 & -390 & -246 & -71 \\
\hline 90 & -160 & -318 & 79 & 63 & -286 & -192 & -64 \\
\hline 110 & -47 & -159 & 56 & 47 & $\begin{array}{l}-107 \\
\end{array}$ & -98 & -56 \\
\hline
\end{tabular}




\subsection{ANEXO - C: Tensão Residual por Difração de Raios-X na superfície}

Tabela 19. Resultados de Tensão Residual Superficial no sentido circunferencial.

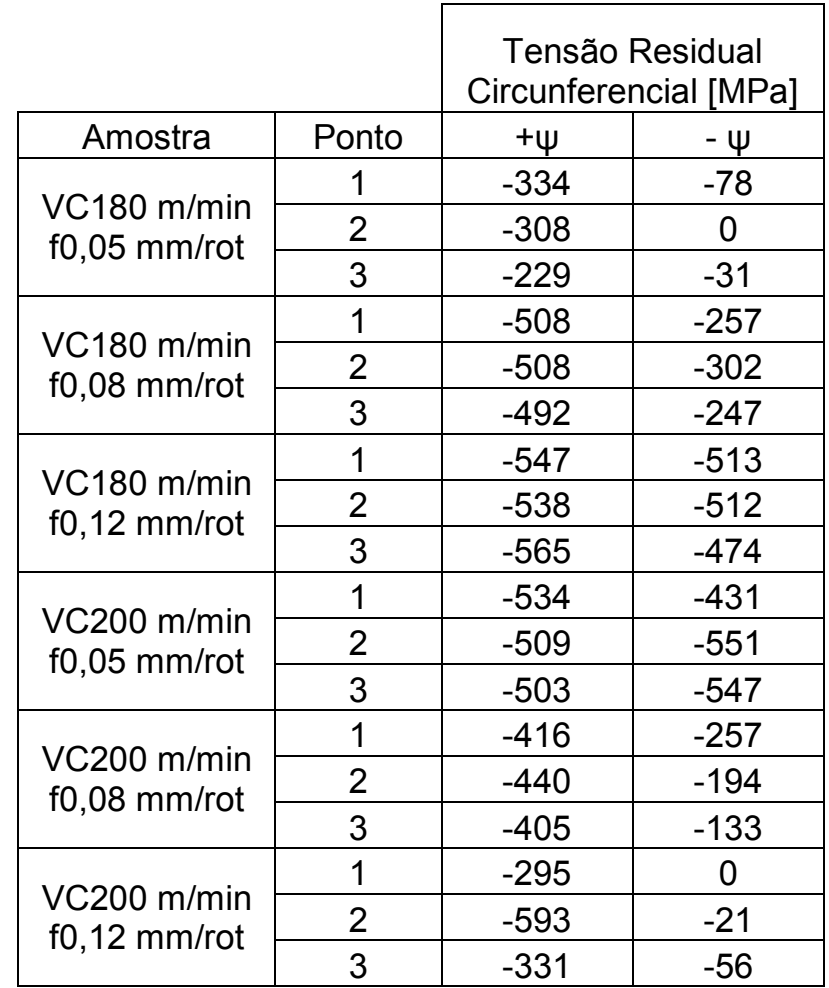




\subsection{ANEXO - D: Análise da variância dos Resultados de Tensão residual com o software Minitab 15}

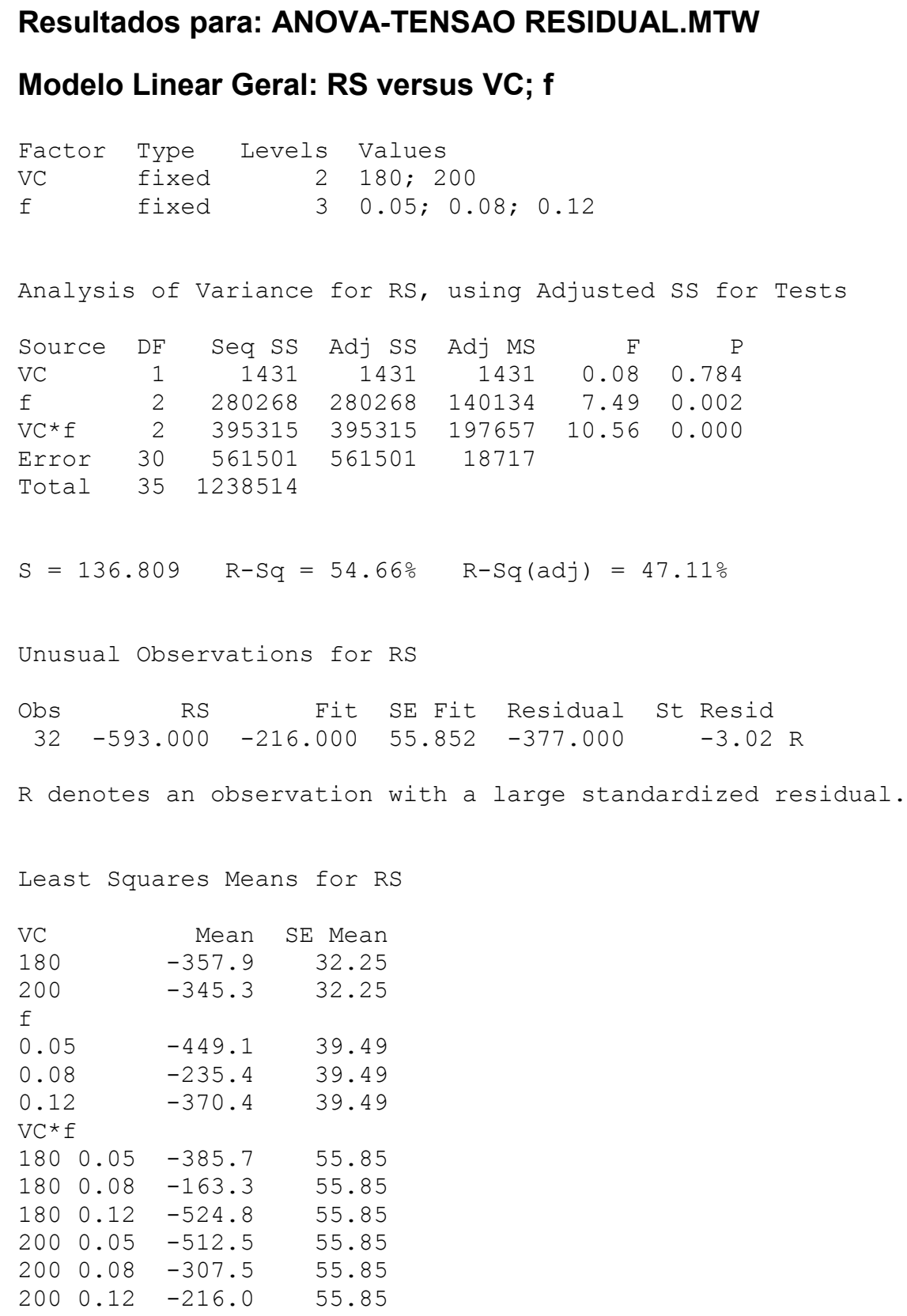

ANOVA Dois parâmetros: RS versus VC; $f$

$\begin{array}{lrrrrr}\text { Source } & \text { DF } & \text { SS } & \text { MS } & F & P \\ \text { VC } & 1 & 1431 & 1431 & 0.08 & 0.784 \\ \mathrm{f} & 2 & 280268 & 140134 & 7.49 & 0.002 \\ \text { Interaction } & 2 & 395315 & 197657 & 10.56 & 0.000 \\ \text { Error } & 30 & 561500 & 18717 & & \\ \text { Total } & 35 & 1238514 & & & \\ \text { S }=136.8 & \mathrm{R}-\mathrm{Sq}=54.66 \% & \mathrm{R}-\mathrm{Sq}(\operatorname{adj})=47.11 \%\end{array}$



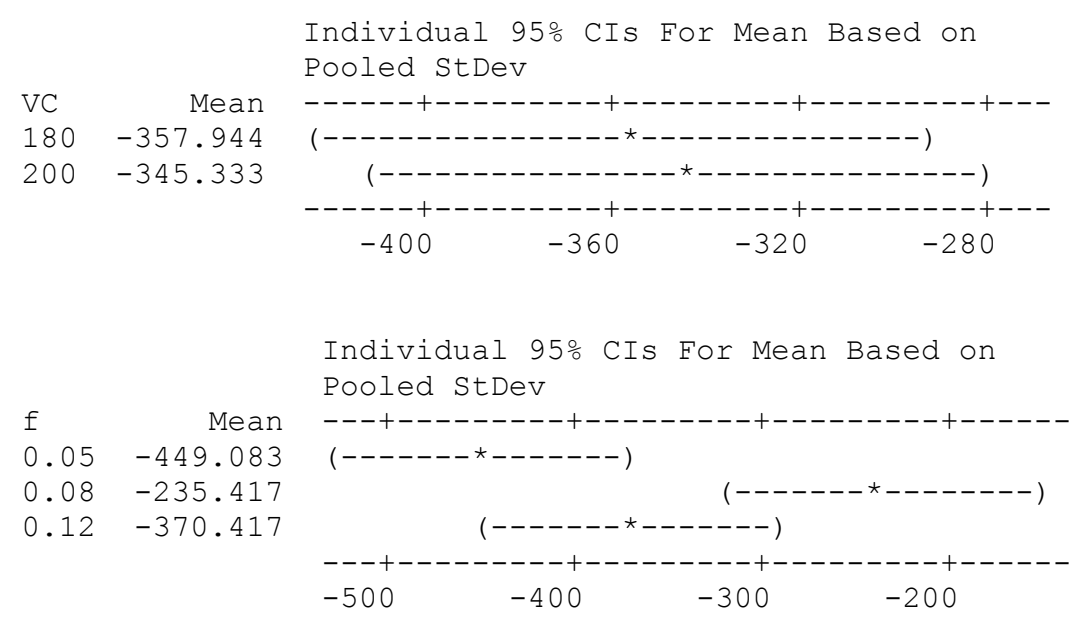

Gráficos de análise de resíduos:

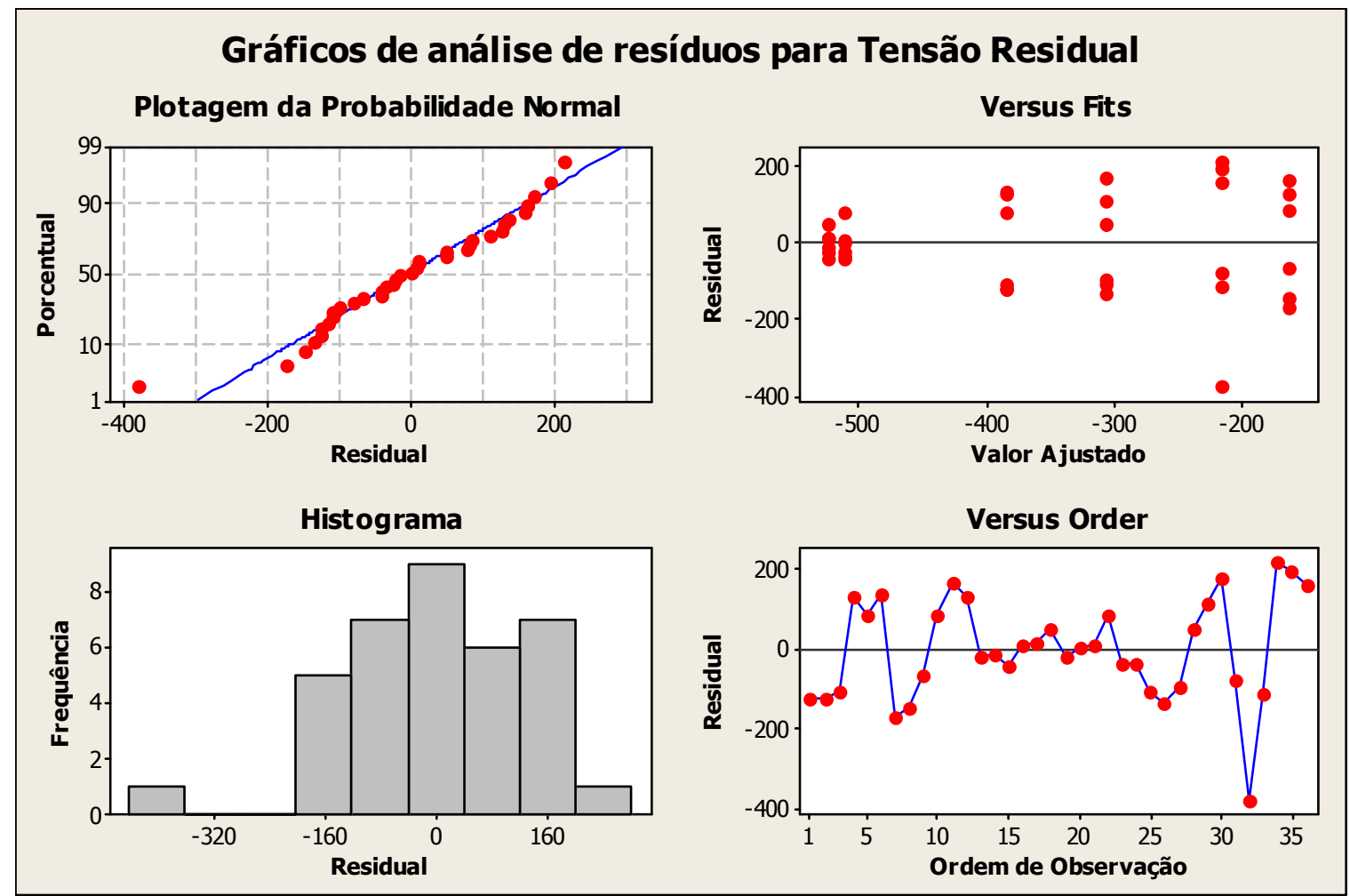

Figura 153. Gráficos de análise de resíduos. 


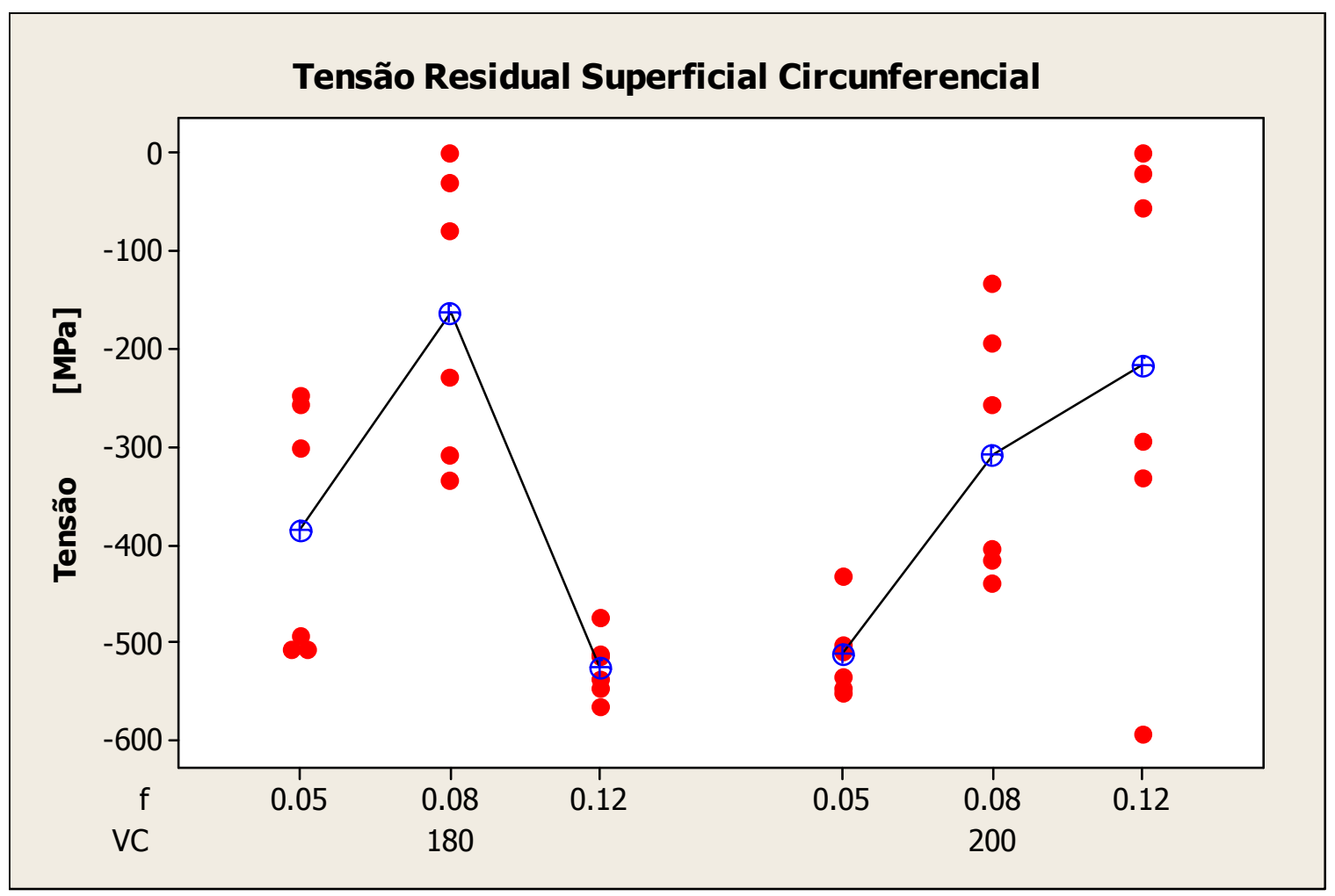

Figura 154. Gráficos de análise das medições de tensão encontradas na superfície. 
9.5 ANEXO - E: Resultados da medição topográfica 3-D

Tabela 20. Resultados da medição topográfica 3-D.

\begin{tabular}{|c|c|c|c|c|c|c|c|c|c|c|c|}
\hline & & & \multicolumn{6}{|c|}{ Amostras } & & & \\
\hline VC & $f$ & & 1 & 2 & \begin{tabular}{l|l}
3 \\
\end{tabular} & 4 & 5 & 6 & Média & Desv Pad & \\
\hline & & & & & & & & & & & \\
\hline 180 & 0.05 & Sa & 0.0829 & 0.0832 & 0.0831 & 0.0928 & 0.098 & 0.0855 & 0.08758 & \begin{tabular}{|l|}
0.006345 \\
\end{tabular} & um \\
\hline 180 & 0.08 & Sa & 0.159 & 0.204 & 0.192 & 0.265 & 0.16 & 0.207 & 0.1978 & 0.0390 & um \\
\hline 180 & 0.12 & Sa & 0.136 & 0.13 & 0.14 & 0.169 & 0.187 & 0.188 & 0.1583 & 0.0263 & um \\
\hline 200 & 0.05 & Sa & 0.074 & 0.094 & 0.0926 & 0.0963 & 0.105 & 0.106 & 0.0947 & 0.0116 & um \\
\hline 200 & 0.08 & $\mathrm{Sa}$ & 0.177 & 0.176 & 0.188 & 0.244 & 0.195 & 0.177 & 0.1928 & 0.0262 & um \\
\hline 200 & 0.12 & Sa & 0.255 & 0.213 & 0.223 & 0.205 & 0.192 & 0.227 & 0.2192 & 0.0216 & um \\
\hline Retificado & & Sa & 0.576 & 0.635 & 0.694 & & & & 0.6350 & 0.0590 & um \\
\hline 180 & 0.05 & Sa1 & 3.76 & $\begin{array}{l}4.58 \\
\end{array}$ & 3.74 & 4.93 & 5.67 & 3.76 & 4.4067 & 0.7976 & um3/mm2 \\
\hline 180 & 0.08 & Sa1 & 11.2 & 5.72 & 5.83 & 3.38 & 8.3 & 4.98 & 6.5683 & 2.7714 & um3 $/ \mathrm{mm} 2$ \\
\hline 180 & 0.12 & Sa1 & 3.54 & 7.11 & 6.06 & 12.1 & 11.2 & 9.45 & 8.2433 & 3.2633 & um3/mm2 \\
\hline 200 & 0.05 & $\widehat{S a 1}$ & 3.56 & 5.78 & 6.05 & 8.41 & 9.25 & 9.19 & 7.0400 & 2.2831 & um3/mm2 \\
\hline 200 & 0.08 & Sa1 & 2.07 & 6.17 & 5.87 & 3.82 & 6.4 & 1.14 & 4.2450 & 2.2602 & um3 $/ \mathrm{mm} 2$ \\
\hline 200 & 0.12 & Sa1 & 13.6 & 2.89 & 1.16 & 11.1 & 14.6 & 8.28 & 8.6050 & 5.5733 & um3/mm2 \\
\hline Retificado & & Sa1 & 39.9 & 46.4 & 25.2 & & & & 37.1667 & \begin{tabular}{|l|}
10.86109 \\
\end{tabular} & um3 $/ \mathrm{mm} 2$ \\
\hline 180 & 0.05 & $\mathrm{Sa} 2$ & 4.92 & 5.43 & 5.47 & 5.18 & 4.9 & 6.61 & 5.4183 & 0.6319 & um3 $/ \mathrm{mm} 2$ \\
\hline 180 & 0.08 & $\mathrm{Sa} 2$ & 9.51 & 11.3 & 8.81 & 24.2 & 4.02 & 11.9 & 11.6233 & 6.7608 & um $3 / \mathrm{mm} 2$ \\
\hline 180 & 0.12 & $\mathrm{Sa} 2$ & 2.73 & 2.85 & 3.06 & 5.03 & 4.93 & 9.53 & 4.6883 & 2.5878 & um3/mm2 \\
\hline 200 & 0.05 & $\mathrm{Sa} 2$ & 4.32 & 5.49 & 5.27 & 6.99 & 5.58 & 6.66 & 5.7183 & 0.9728 & um3/mm2 \\
\hline 200 & 0.08 & $\mathrm{Sa} 2$ & 6.8 & 7.87 & 7.18 & 1.62 & 7.06 & 4.25 & 5.7967 & 2.3938 & um3/mm2 \\
\hline 200 & 0.12 & $\mathrm{Sa} 2$ & 14 & 12.1 & 4.61 & 11.6 & 10.5 & 3.43 & 9.3733 & 4.3146 & um3 $/ \mathrm{mm} 2$ \\
\hline Retificado & & $\mathrm{Sa} 2$ & 64.2 & 76.3 & 81.9 & & & & 74.1333 & 9.046731 & um3/mm2 \\
\hline 180 & 0.05 & Sk & 0.273 & 0.269 & 0.272 & 0.306 & 0.322 & 0.276 & 0.2863 & $\begin{array}{l}0.0221 \\
\end{array}$ & um \\
\hline 180 & 0.08 & Sk & 0.506 & 0.673 & 0.64 & 0.855 & 0.545 & 0.709 & 0.6547 & 0.1247 & um \\
\hline 180 & 0.12 & Sk & 0.493 & 0.433 & 0.478 & 0.533 & 0.591 & 0.61 & 0.5230 & 0.0683 & um \\
\hline 200 & 0.05 & Sk & 0.242 & 0.304 & 0.299 & 0.295 & 0.33 & 0.327 & 0.2995 & 0.0317 & um \\
\hline 200 & 0.08 & Sk & 0.617 & 0.599 & 0.652 & 0.781 & 0.69 & 0.634 & 0.6622 & 0.0661 & um \\
\hline 200 & 0.12 & Sk & 0.814 & 0.717 & 0.822 & 0.681 & 0.618 & 0.838 & 0.7483 & 0.0898 & um \\
\hline Retificado & & Sk & 1.74 & 1.85 & 2.12 & & & & 1.9033 & 0.1955 & um \\
\hline \begin{tabular}{|r|}
180 \\
\end{tabular} & 0.05 & Sku & 3.02 & 3.24 & 3 & 3.08 & 2.85 & 3.15 & 3.0567 & 0.1343 & um \\
\hline 180 & 0.08 & Sku & 4.42 & 2.46 & 2.77 & 3.03 & 2.59 & 2.81 & 3.0133 & 0.7162 & um \\
\hline 180 & 0.12 & Sku & 2.34 & 2.62 & 2.91 & 2.62 & 2.75 & 2.67 & 2.6517 & 0.1876 & um \\
\hline 200 & 0.05 & Sku & 2.97 & 3.2 & 3.18 & 4.79 & 4.09 & 3.58 & 3.6350 & 0.6903 & um \\
\hline 200 & 0.08 & Sku & 2.49 & 2.78 & 2.44 & 1.87 & 2.61 & 2.05 & 2.3733 & 0.3456 & um \\
\hline 200 & 0.12 & Sku & 2.61 & 2.6 & 2.05 & 3.06 & 3.94 & 2.86 & 2.8533 & 0.6312 & um \\
\hline Retificado & & Sku & 4.77 & 5.82 & 3.96 & & & & 4.8500 & 0.9326 & um \\
\hline \begin{tabular}{|l|}
180 \\
\end{tabular} & 0.05 & Spk & 0.0842 & 0.0962 & 0.0861 & 0.109 & 0.111 & 0.079 & 0.0943 & 0.0134 & um \\
\hline 180 & 0.08 & Spk & 0.232 & 0.181 & 0.177 & 0.16 & 0.16 & 0.162 & 0.1787 & 0.0277 & um \\
\hline 180 & 0.12 & Spk & 0.105 & 0.131 & 0.118 & 0.182 & 0.171 & 0.196 & 0.1505 & 0.0374 & um \\
\hline 200 & 0.05 & Spk & 0.0761 & 0.118 & 0.123 & $\begin{array}{l}0.17 \\
\end{array}$ & 0.176 & 0.163 & 0.1377 & 0.0389 & um \\
\hline 200 & 0.08 & Spk & 0.103 & 0.15 & 0.141 & 0.115 & 0.188 & 0.0733 & 0.1284 & 0.0401 & um \\
\hline 200 & 0.12 & Spk & 0.265 & 0.141 & 0.0829 & 0.317 & 0.321 & 0.323 & 0.2417 & 0.1044 & um \\
\hline Retificado & & Spk & 0.645 & 0.962 & 0.639 & & & & 0.7487 & 0.1848 & um \\
\hline \begin{tabular}{|l|}
180 \\
\end{tabular} & 0.05 & $\mathrm{Sq}$ & 0.103 & 0.105 & 0.104 & 0.116 & 0.122 & 0.108 & 0.1097 & 0.0077 & um \\
\hline 180 & 0.08 & $\mathrm{Sq}$ & 0.204 & 0.247 & 0.232 & 0.326 & 0.196 & 0.254 & 0.2432 & 0.0466 & um \\
\hline 180 & 0.12 & $\mathrm{Sq}$ & 0.162 & 0.157 & 0.169 & 0.205 & 0.224 & 0.232 & 0.1915 & \begin{tabular}{|l|}
0.033002 \\
\end{tabular} & um \\
\hline 200 & 0.05 & $S q$ & 0.0922 & 0.119 & 0.117 & 0.127 & 0.135 & 0.136 & 0.12103 & \begin{tabular}{|l|}
0.016164 \\
\end{tabular} & um \\
\hline 200 & 0.08 & $\mathrm{Sq}$ & 0.208 & 0.217 & 0.229 & 0.255 & 0.237 & 0.206 & 0.22533 & 0.018833 & um \\
\hline 200 & 0.12 & $S q$ & 0.315 & 0.255 & 0.259 & 0.257 & 0.246 & 0.273 & 0.2675 & 0.02485 & um \\
\hline Retificado & & Sq & 0.757 & 0.858 & 0.893 & & & & 0.8360 & 0.0706 & um \\
\hline 180 & 0.05 & Sr1 & $\begin{array}{l}8.92 \\
\end{array}$ & $\begin{array}{l}9.48 \\
\end{array}$ & 8.69 & 9.06 & 10.2 & 9.51 & 9.31 & 0.54037 & $\%$ \\
\hline 180 & 0.08 & $\mathrm{Sr} 1$ & 9.64 & 6.31 & 6.59 & 4.23 & 10.4 & 6.14 & 7.2183 & 2.3367 & $\%$ \\
\hline 180 & 0.12 & $\mathrm{Sr} 1$ & 6.78 & 10.8 & 10.3 & 13.3 & 13.2 & 9.63 & 10.6683 & 2.4366 & $\%$ \\
\hline 200 & 0.05 & Sr1 & 9.34 & 9.82 & 9.82 & 9.9 & 10.5 & 11.2 & 10.0967 & 0.6549 & $\%$ \\
\hline 200 & 0.08 & Sr1 & 4.03 & 8.23 & 8.31 & 6.63 & 6.81 & 3.1 & 6.1850 & 2.1655 & $\%$ \\
\hline 200 & 0.12 & Sr1 & 10.3 & 4.1 & 2.81 & 6.99 & 9.08 & 5.13 & 6.4017 & 2.9166 & $\%$ \\
\hline Retificado & & Sr1 & 9.59 & 9.65 & 7.9 & & & & 9.0467 & 0.9935 & $\%$ \\
\hline 180 & 0.05 & Sr2 & 90.2 & 89.8 & 89.3 & 90.7 & 90.8 & 89.8 & 90.1000 & 0.5797 & $\%$ \\
\hline 180 & 0.08 & $\mathrm{Sr} 2$ & 90.4 & 88.5 & 90 & 86.2 & 93 & 90.7 & 89.8000 & 2.2847 & $\%$ \\
\hline 180 & 0.12 & $\mathrm{Sr} 2$ & 94.6 & 94.3 & 94 & 93.9 & 96.1 & 88.7 & $\begin{array}{l}93.6 \\
\end{array}$ & \begin{tabular}{|l|}
2.529822 \\
\end{tabular} & $\%$ \\
\hline 200 & 0.05 & $\mathrm{Sr} 2$ & 89.8 & 90.4 & 90.2 & 89.1 & 91.2 & 89.8 & 90.0833 & 0.705455 & $\%$ \\
\hline 200 & 0.08 & $\mathrm{Sr} 2$ & 91.9 & 91.3 & 91.8 & 97 & 92.2 & 93.5 & 92.95 & 2.11731 & $\%$ \\
\hline 200 & 0.12 & Sr2 & 88.5 & 89.8 & 94 & 89.6 & 90.8 & 95.4 & 91.35 & \begin{tabular}{|l|}
2.731849 \\
\end{tabular} & $\%$ \\
\hline Retificado & & Sr2 & 88.1 & 87.4 & 86.9 & & & & 87.4667 & \begin{tabular}{|l|}
0.602771 \\
\end{tabular} & $\%$ \\
\hline 180 & 0.05 & Ssk & -0.0999 & -0.0653 & -0.136 & -0.0376 & 0.0447 & -0.289 & \begin{tabular}{|l|}
-0.0972 \\
\end{tabular} & \begin{tabular}{|l}
0.1123 \\
\end{tabular} & um \\
\hline 180 & 0.08 & Ssk & 0.00199 & $\begin{array}{l}-0.134 \\
\end{array}$ & $\begin{array}{l}-0.0735 \\
\end{array}$ & -0.523 & 0.194 & -0.264 & \begin{tabular}{|l|}
-0.1331 \\
\end{tabular} & 0.2441 & um \\
\hline 180 & 0.12 & Ssk & 0.0627 & 0.219 & 0.168 & 0.209 & 0.0635 & \begin{tabular}{|l|}
0.0653 \\
\end{tabular} & 0.1313 & 0.0758 & um \\
\hline 200 & 0.05 & Ssk & -0.0833 & 0.0384 & 0.097 & 0.376 & 0.258 & 0.219 & 0.1509 & 0.1656 & um \\
\hline 200 & 0.08 & Ssk & $\begin{array}{l}-0.174 \\
\end{array}$ & -0.0867 & -0.0408 & 0.0238 & -0.00985 & -0.131 & -0.0698 & 0.0749 & um \\
\hline 200 & 0.12 & Ssk & 0.00202 & -0.301 & -0.122 & 0.042 & 0.255 & 0.281 & 0.0262 & 0.2223 & um \\
\hline Retificado & & Ssk & -0.582 & -0.357 & -0.597 & & & & -0.5120 & 0.1344 & um \\
\hline 180 & 0.05 & Svk & 0.1 & 0.107 & 0.103 & 0.112 & 0.106 & 0.128 & 0.10933 & 0.009993 & um \\
\hline 180 & 0.08 & Svk & 0.198 & 0.196 & 0.177 & 0.352 & 0.114 & 0.256 & 0.2155 & 0.080924 & um \\
\hline 180 & 0.12 & Svk & 0.102 & 0.0999 & 0.102 & 0.165 & 0.25 & 0.169 & 0.1480 & 0.0595 & um \\
\hline 200 & 0.05 & Svk & 0.085 & 0.115 & 0.107 & 0.128 & 0.127 & 0.131 & 0.1155 & 0.0175 & um \\
\hline 200 & 0.08 & Svk & 0.168 & 0.18 & 0.175 & 0.107 & 0.181 & 0.131 & 0.1570 & 0.0307 & um \\
\hline 200 & 0.12 & Svk & 0.244 & 0.237 & 0.153 & 0.224 & 0.23 & 0.148 & 0.2060 & 0.0435 & um \\
\hline Retificado & & Svk & 1.08 & $\begin{array}{l}1.21 \\
\end{array}$ & $\begin{array}{l}1.25 \\
\end{array}$ & & & & 1.1800 & 0.0889 & um \\
\hline
\end{tabular}




\section{Trabalhos completos publicados em anais de congressos}

Farias, A., Delijaicov, S., Biasoli de Mello, J. D., Stipkovic, M., Batalha, G., Análise da tensão residual no processo de torneamento duro do aço AISI 8620 cementado através de extensometria e a sua correlação com a integridade superficial., V Congresso Nacional de Engenharia Mecânica - CONEM 2008, v. 1. p. 1-418.

Farias, A., Delijaicov, S., Biasoli de Mello, J. D., Stipkovic, M., Batalha, G., Surface integrity and residual stresses analysis by strain gages after hard turning process of case hardened steel AISI 8620., Advances in Materials and Processing Technologies (AMPT), 2008, Manama, Kingdom of Bahrain, 2008.

\section{Artigos aceitos para publicação}

Farias, A., Delijaicov, S., Biasoli de Mello, J. D., Stipkovic, M., Batalha, G.,Surface Integrity Functional Analysis in Hard Turning AISI 8620 Carburized Steel, Through Topographical Measurement, $10^{\text {th }}$ CIRP International Workshop on Modeling of Machining Operations, 2009.

Farias, A., Delijaicov, S., Biasoli de Mello, J. D., Stipkovic, M., Batalha, G., Análise funcional da integridade superficial no processo de torneamento duro do aço ABNT 8620 cementado através da sua medição topográfica superficial, $V$ CONGRESSO BRASILEIRO DE ENGENHARIA DE FABRICAÇÃO - COBEF, 2009.

Farias, A., Delijaicov, S., Biasoli de Mello, J. D., Stipkovic, M., Batalha, G., Avaliação experimental das tensões residuais em superfícies usinadas após torneamento de componentes mecânicos fabricados com aço cementado DIN 21NiCrMo2 (AISI 8620), V CONGRESSO BRASILEIRO DE ENGENHARIA DE FABRICAÇÃO - COBEF, 2009.

Farias, A., Donato, G. H., Delijaicov, S., Batalha, G., Análise da tensão residual no processo de torneamento duro do aço AISI 8620 cementado através de extensometria e a sua correlação com a integridade superficial. Máquinas e Metais, 2009. 
ADALTO DE FARIAS

Data de nascimento: 27/02/1976 - São Bernardo do Campo - S.P.

adalto.de.farias@gmail.com

Experiência Acadêmica

Técnico em Desenho de Projetos de Mecânica

1990-1994 Escola secundária: Escola Técnica Estadual Lauro Gomes FEI - São

Bernardo do Campo - S.P.

Engenharia Mecânica Automobilística

1999-2004 Graduação: UNIFEI - Centro Universitário da FEI - São Bernardo do

Campo - S.P.

Mestrado em Engenharia Mecânica

2007-2009 Pós Graduação: EPUSP - Escola Politécnica da USP - São Paulo - S.P.

\section{Experiência Profissional}

1993-1995 Polimold Ind. S/A: Operador/Fresador CNC 1996-2000 Polimold Ind. S/A: Programador CNC 2000-2005 Polimold Ind. S/A: Técnico de Processos 2006-2009 Polimold Ind. S/A: Supervisor de Produção 